Andrews University

Digital Commons @ Andrews University

1980

\title{
The Church As Family: A Study of Viability in the Smaller Local Seventh-day Adventist Church
}

Kerry H. Hortop

Andrews University

Follow this and additional works at: https://digitalcommons.andrews.edu/dmin

Part of the Practical Theology Commons

\section{Recommended Citation}

Hortop, Kerry H., "The Church As Family: A Study of Viability in the Smaller Local Seventh-day Adventist Church" (1980). Professional Dissertations DMin. 600.

https://dx.doi.org/10.32597/dmin/600

https://digitalcommons.andrews.edu/dmin/600

This Project Report is brought to you for free and open access by the Graduate Research at Digital Commons @ Andrews University. It has been accepted for inclusion in Professional Dissertations DMin by an authorized administrator of Digital Commons @ Andrews University. For more information, please contact repository@andrews.edu. 


\begin{abstract}
THE CHURCH AS FAMILY: A STUDY OF VIABILITY IN THE SMALLER LOCAL SEVENTH-DAY ADVENTIST CHURCH
\end{abstract}

Kerry H. Hortop

Chairperson: Norman Miles 


\title{
ABSTRACT OF GRADUATE STUDENT RESEARCH: PROJECT
}

\author{
Aridrews University
}

Seventh-day Adventist Theological Seminary

\author{
TitTe: THE CHURCH AS FAMILY: A STUDY OF VIABILJTY IN THE SMALLER \\ LOCAL SEVENTH-DAY ADVENTIST CHURCH \\ Name or researcher: Kerry H. Hortop \\ Name and degree of faculty adviser: Norman Miles, Ph.D. \\ Date completed: August 1980.
}

Smail churches form such a large part of the Christian church, and of the Seventh-day Adventist denomination in particular, that it was felt desirable that the viability of the small church should be examined.

An examination is made of current theological thought relevant to the sma11 church. This was followed by a study both of family-style motifs and famiiy-style practice by the church in the New Testament.

Sociopsychological factors which effect and aiso explain the operation and "personality" of the small church are noted from relevant recent iiterature and studies. Some church-growth and organizational projects involving small churches are included in the sociopsychological section, which aims to provide reasons and rationale as to why small churches act as they do, and from this to 
isolate their strengths and weaknesses.

It was felt desirable to examine the organizational structure of the Seventh-day Adventist church, particularly as formulated in the Church Manual, from the aspect of its influence and effect upon the small church.

A viability project conducted in the small Seventh-day Adventist church in Otsego, Michigan, is included. In this local project an attempt is made to deduce the viability of this small church in comparison with and in contrast to the characteristics of the typical small church--as established through the study of the NT, the Apostolic church, and current literature. The object of the viability study was to help this small church to assess itself and, within its viability potential, make tangible goals for the future.

The conclusion contains recommendations for reorganization of small churches and suggestions as to how viability can be improved. Cautions are given concerning certain changes which may not be for the better, especially when they run counter to the characteristics of the small church. Some suggestions are made, with certain reservations, as to an optimum size for Seventh-day Adventist churches. These propositions have grown out of the consideration of the most successful balance between strong family fellowship and the meeting of denominationar, Biblical, and individual needs within a worshiping community. 
Andrews University

Seventh-day Adventist Theological Seminary

THE CHURCH AS FAMILY: A STUDY OF VIABILITY IN

THE SMALLER LOCA.L SEVENTH-DAY ADVENTIST CHURCH

\author{
A Project Report \\ Presented in Partial fulfillment \\ of the Requirements for the Degree \\ Doctor of Ministry
}

by

Kerry H. Hortop

August 1980 

THE CHURCH AS FAMILY: A STUDY OF VIABILITY IN

THE SMALLER LOCAL SEVENTH-DAY ADVENTIST CHURCH

\author{
A Project Report \\ Presented in Partial Fulfillment \\ of the Requirements for the Degree \\ Doctor of Ministry
}

by

Kerry H. Hortop

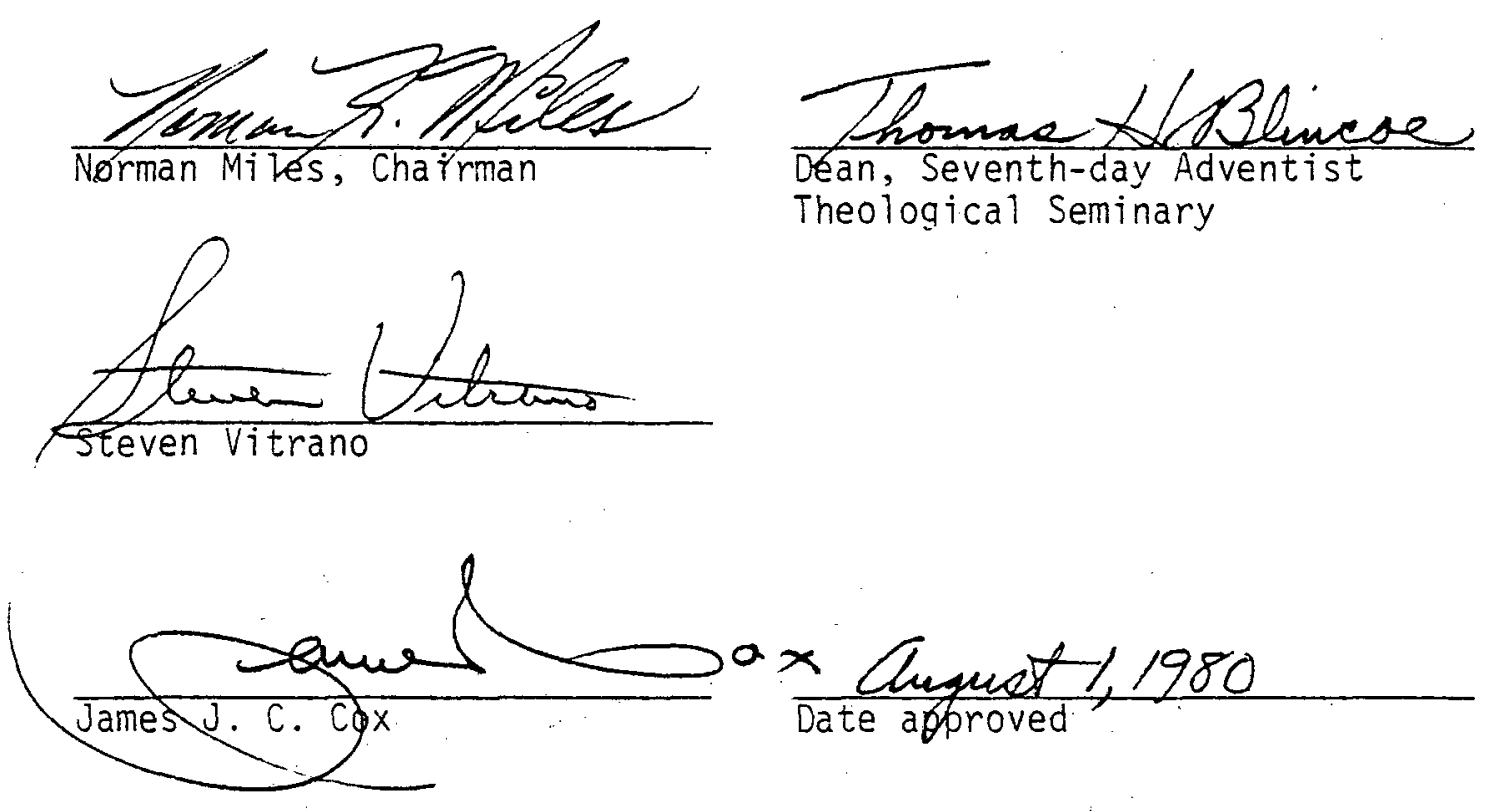


DEDICATED TO

Pam, Paul, Julie, Ann, and Mark 
TABLE OF CONTENTS

LIST OF ILLUSTRATIONS ......................... vii

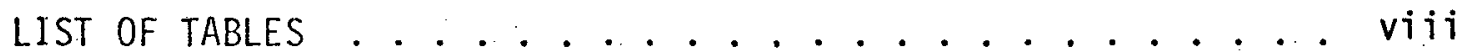

ACKNOWLEDGEMENTS ..................... ix

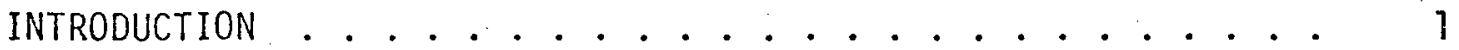

General ................ . . . 1

Justification of the Project . . . . . . . . . 2

Thesis .................. . . 4

Definition of Terms ............. . . . 4

Guidelines and Report Process and Development...... 5

Report Process and Development ......... 6

Chapter

I. THE CHURCH AS FAMILY .............. 8

Contemporary Theological Views . . . . . . . 8

Family Style Cormunity in the Church ....... 8

A Tripartite Existence . . . . . . . . . . 13

A Total "Charismatic" Community. . . . . . . . . 17

A New Testament. Theological View . . . . . . . . . 21

The Family of God . . . . . . . . . . . . . 21

The Church as Sons and Daughters ........ . 25

Children Like Their Father . . . . . . . . 26

Children by faith............. 30

Blameless, separated and yet not separated children 36

The Church as a Loving Household . . . . . . . . . 39

The household of God .............. . . . . 39

The household of love ............ 41

Theological Conclusions ............ 45

A New Testament Practical View ......... . 46

Preparation, Power, and Witness ......... 48

Administration and Structure ......... 52

Worship, Fellowship, and Growth........ 55

II. THE CHURCH AS FAMILY-SOCIOPSYCHOLOGICAL VIEWS . . . . 59

Characteristics Peculiar to the Smaller Church . . . 59

What is Smal1?.................. 59

Interpersonal Relationships ......... 62

Operational Methods ............ 63 
Meeting Needs within the Small Church ....... 65

Limited Plant and Programs . . . . . . . . . . 65

Individual Personal Needs .......... . 67

Long-time members .......... . . 67

Potential new members .......... . 68

New baptized members ............. 72

"Interna! growth" members ........ . . 75

Age, Social, and Interest Groups Within

the Small Church . . . . . . . . . . . . . 78

The Family Function Model for Need Fulfillments . . . . 84

Examination of Growth and Viability Potential

in the Small Church .............. 88

Recent Seventh-day Adventist Studies . ....... . 93

Summary ................ . 101

III. THE CHURCH AS FAMILY--IN RELATION TO CURRENT

SEVENTH-DAY ADVENTIST STRUCTURES . . . . . . . . . 104

Family Member Preparation . . . . . . . . 107

Accession into the Family ......... . . 107

Lay Involvement, Ministry, and Training. . . . . . 111

Worship and Mission . . . . . . . . . . . 114

Administration and Structure . . . . . . . . 116

Denominational Guidelines .......... . . 116

At higher levels............. . . . 116

Organizational cautions . . . . . . . . . 119

Program Initiators or Reactors . . . . . . . . . 120

Faith Action Advance 1979 . . . . . . . . . . . 122

Fellowship and Growth .............. . . 129

Relationship with Sister Churches . . . . . . . 129

Auxiliary Organizations and Groups . . . . . . . 132

Direction of Future Change ......... . 135

IV. THE CHURCH AS FAMILY--IN THE LOCAL OTSEGO, MICHIGAN,

CHURCH .137

History of the Church . . . . . . . . . 137

Period of Growth--1861-1918 . . . . . . . . . 137

Period of Decline--1919-1972 . . . . . . . . . . . . 140

Period of Revival--1973-1980 . . . . . . . . . . 143

Description of the Viability Project ....... . . 144

The Congregational Survey .......... . 145

Assessment of Results . . . . . . . . . . 149

Family Functions . . . . . . . . . . . . . 158

Summary .............. . . . . . 159

Outgrowth of Results ........... 160

Personal Views of the Church Family . . . . . . . 164

Long time members .............. . . 165

Visitors and new members ............. . 168

My Evaluation . . . . . . . . . . . . 171 
V. THE CHURCH AS FAMILY--CONCLUSIONS AND SUGGESTIONS . . . 178

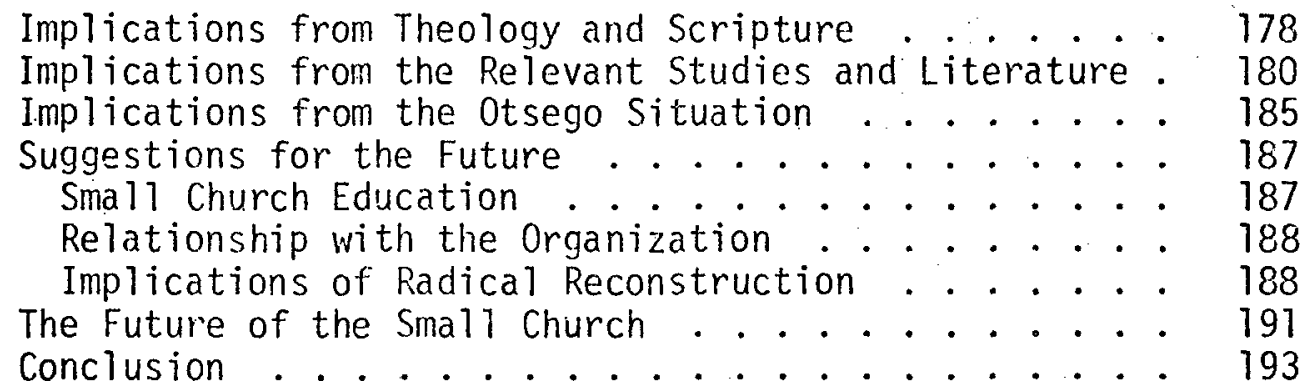

APPENDIX A. CONGREGATIONAL MEMBERSHIP SIZE TO NUMBER OF

CHURCHES IN DENOMINATION .......... 195

APPENDIX B. EARLY CHURCH CONGREGATIONAL SIZE AND

PASTOR-LAY IMPORTANCE . . . . . . . . . 197

APPENDIX C. RELEVANT PORTION OF OTSEGO CHURCH BOARD-MEETING

HELD TUESDAY, APRIL 22, $1979 \ldots . . . . . . .199$

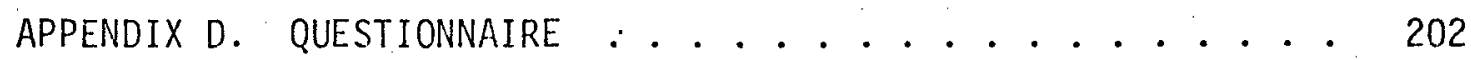

APPENDIX E. LARGE QUESTIONNAIRE . . . . . . . . 206

APPENDIX F. RESPONSES TO LARGE QUESTIONNAIRE . . . . . . 224

APPENDIX G. VERBATIM REPORT OF INTERVIEWS ........ 242

BIBLIOGRAPHY . . . . . . . . . . . . . . 296 


\section{LIST OF ILLUSTRATIONS}

\section{Figure}

1. Graph of Church "Kingdom Growth" per 1000 members in relation to church congregational size............... 183

2. Graph of Church Growth per 1000 members in relation to church congregational size . . . . . 184 


\section{LIST OF TABLES}

Table

1. North American Division Seventh-day Adventist

Churches (sizes by percentage, 1980).......... 99

2. Church Size and Growth . . . . . . . . . . . . 99

3. Church Size and "Kingdom Growth" .. . . . . . . 100

4. Responses to Questions $3-12$ on Questionnaire (Appendices E and F) .............. . . 152

5. Responses to Questions 13, 15, 16 on Questionnaire . . 153

6. Responses to Questions 18-22 on Questionnaire . . . . 154

7. Questionnaire results for Family Functions . . . . . 158

8. Size of Church and "Kingdom Growth" per 1000 Church Members.................. 183

9. Size of Church and Growth per 1000 Church Members . . 184 


\section{ACKNOWLEDGEMENTS}

I wish first of a 11 to express my gratitude to the Lord for His saving grace, His daily strength, and His call to the gospel ministry.

I would like to thank the Australasian Division for their support and encouragement throughout this doctoral progran and Andrews University and the Seventh-day Adventist Theological Seminary for providing the Doctor of Ministry course of study.

The guidance of my committee chairman Dr. Norman Miles, was greatly appreciated, as was the encouragement given by $\mathrm{Dr}$. Arnold Kurtz, particulariy in the embryo stage of development of this project. Dr. Steven Vitrano made useful contributions and gave enthusiastic support throughout the writing of the report. I would like to thank $\mathrm{Dr}$. James Cox for his time and interest in reading and improving the manuscript in the final stage of the report.

The friendly, loving members of the otsego church have encouraged me in continuing with this project and have cooperated in the research and application of it.

Robyn Mitchell and Deirdre Lindsay deserve thanks for their contribution in typing sections of the report--often done at short notice and yet with cheerfulness and willingness. A special thanks is deserved for Gail Valentine as she so graciously labored over typing the final copy: 
Without the understanding and encouragement of my family this project would never have been completed and so I would like to reserve a very special appreciation to my parents and my wife and children for their patient, loving support. 


\section{INTRODUCTION}

\section{General}

Having pastored in a number of small churches I have become interested in the dynamics which govern the operation of these organizations. In the prevailing climate of this century, the small church seems an anomalous organization, perhaps one which by all the "rules" should not still be in existence. Yet as a number of authors have pointed out, small churches are still very much with us and are very tenaciously hanging on to life. 'This is true to such an extent that in most Protestant denominations, churches with a membership attendance below seventy-five constitute over 33 percent of the churches in each respective denomination, with no indication that this situation will change very much in the near future. 2

Since the end of the 1960s there has been an increasing interest in small organizations, including small churches. Some of these studies have been quite interesting and reflect upon the potential for the growth and viability of small congregations. I wish to look briefly at some of this material as well as reflect upon it in the light of the structures and developments within my own

${ }^{1}$ Carl S. Dudley, Making the Small Church Effective (Nashville: Abingdon, 1979), p. 21.

${ }^{2}$ Lyle E. Schaller, "Looking at the Small Church," Christian Ministry 8 (JuTy 1977): 66 . 
Seventh-day Adventist denomination. This denomination is well in the mainstream of Protestant churches in that it too has developed a predominant structure of small churches, having over one third of its churches in North America below a membership of fifty; over 60 percent below a membership of one hundred; and over 80 percent below a membership of two hundred.' The statistics for the worldwide church are probably even more skewed towards the predominance of small churches.

Hence from the actual situation existing within the Christian church in North America there is need of further examination of the small church and its viability.

McGavran and others in the Church-Growth movement see small groups as most important for growth. ${ }^{2}$ The implications of this fact for the small church need to be investigated and the sociopsychological factors in operation within such groups needs examination so that the optimum strength can be mobilized within these churches which so often feel as if they have no favorable characteristics or advantages when compared with large congregations.

\section{Justification of the Project}

Although there are many definitions of just what constitutes a "small church," all of them would place the vast majority

INorth American Division Church-Growth Study (Berrien Springs: Andrews University, 1980), mid-project report (forthcoming). See table 1.

${ }^{2}$ Donald A. McGavran and Win Arn, How to Grow a Church (Glendale: G/L Fublications, 1973), pp. 115, 176; 161, 162. Cf. C. Peter Wagner, Your Church Can Grow (Glendale: G/L Publications, 1976), pp. $97-109$. 
of Adventist. churches in this category, and hence a topic dealing with them is relevant to nearly the whole church.

A number of very small Adventist churches (e.g., say below fifty members) are frustrated and exist by a tenuous thread. This. project examines the dominant reasons for their problems, the strengths they may have as a small group; an attempt is also made to formulate suggestions as to how internal or external sources of strength can help them cope with or alleviate the troubles.

Some small churches are in such a situation that for the benefit of al1--the community of congregational members and the conference administration alike--it may be better if they were to close. This project attempts to examine degrees of viability and to indicate the level at which it may be necessary to recommend closure of a church. Because such moves involve a broad range of human dynamics and such closure "solutions" often result in adverse unsuspected results, the personality characteristics of the small church "organism". is examined. It is felt that such guidelines may be helpful for church members, pastors, and conference administrators.

In the light of the belief of the Adventist Church in its unique prophetic role in the world, the characteristics peculiar to the small church are examined and compared with those of larger churches to ascertain in what situations and communities the small church may be better suited to fulfil this role and to give some guidelines on optimum sizes for a new church breeding from an existing congregation. 
Thesis

If the characteristics peculiar to the smaller church are better known, such knowledge will assist in assessing the potential for the existence and growth of established churches and their possible future. In addition, it will provide some guidance for the future establishment of new churches and will possibly indicate minimum factors needed in order that the role of "church" may be fulfilled.

\section{Definition of Terms}

Viability. In the context of this paper the term "viability" means a degree of operational performance whereby the church is at least fairly successful in meeting the various needs within a group calling itself a "church" and which has at least some potential to maintain its existence in the future.

Growth. The term "growth" means both the growth of numbers in church membership and the spiritual fellowship and nurtural development.

Community. "Community" is used in three senses in this paper: (1) the surrounding social milieu within which the local church is placed; (2) the believing group--the congregation--itself; and (3) in its technical sense, the predominantly personalrelationship-oriented group in contrast to a "society" which is predominantly goal or task oriented in its cohesive force.

M.B.O. As used in this paper, the abbreviation M.B.O. stands for Management by 0bjectives as applied to church renewal and growth. R.B.0. (Revitalization by Objectives) or other "ecclesiastical" forms 
have not been used, although the meaning is the same--that of tangible growth and nurturant goals being made at the local church level by the church members themselves who also cutline the specific subgoals and action strategies to reach to or toward the goal or goals they themselves have set. Periodical evaluation of the program is a) so an inherent part of the process.

Kerygma, diakonia, and koinonia. Three Greek words are taken to mean, respectively: (1) kerygma, the doctrine, preaching, and testifying of the truth of the Gospel message; ${ }^{1}$ (2) diakonia, the practical outworking of that Gospel in care, service, help, comfort, and nurture to others--both within and particularly without the believing congregation; and (3) koinonia, the fellowship which develops between believers reconciled to God and which also extends to others outside the church community.

\section{Guidelines and Report Process and Development}

Parameters and Limitations

In this paper I attempt to look at the characteristics which are present in the small church--which is understood as a congregation which acts as a one-cell unit. Certain comparisons are made with large churches which operate as multi-celled organisms, but contrasts and comparisons do not form the inajor part of this paper. Rather the personality of the small church itself is focused upon, particularly its peculiar strengths and characteristics of koinonia

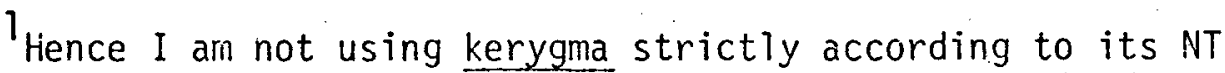
useage--the preaching of the arrival of the Messiah, the Kingdom, the call to repentance, resurrection, but somewhat more broadly to also include didake (teaching) and marturia (witness). 
(or fellowship). I do not wish to place a maximum number-limit on "smal1" or propose a certain ideal size of church--although some practical suggestions in this direction are made in chapter 2 . Nor do I wish to set a minimum membership number for a congregation to call itself a church, because factors other than straight numbers should be taker into account in such a proposition.

Although church growth and church growth principles form an important part of the paper, a discussion of viability may mean more than this, hence I wish to examine the rationale behind the small church operations rather than a model of church growth.

\section{Report Process and Development}

This report is developed along the following lines:

1. A theological study relevant to the small local church is made in the light of: (a) recent scholarship in this area, (b) some relevant New Testament motifs, and (c) actual New Testament practices.

2. Relevant literature is used, together with personal experience and collected data, to ascertain suggested basic requirements for a small church to be viable in view of the characteristics peculiar to the small church.

3. An examination is made of the relationship between denominational expectations and the characteristics, expectations, and

Tome church-growth authors may challenge me on this and suggest that church growth is overwelmingly growth in numbers, and per haps they are correct. However, I have preferred to use "viability" to denote something broader than growth which may still allow some small churches to keep living and feebly swimming rather than sink under the waves of massive inadequacy, inferiority, and guilt which flood from the church-growth success model. 
needs of the small church, with suggestions as to how a more fruitful interaction could be developed.

4. A study is made of the small Otsego, Michigan church to find whether certain negative characteristics can be identified which hold back growth or contribute toward decline, and conversely, which positive factors may have helped maintain its existence and could increase its viability and promote growth.

5. An attempt is made to develop certain basic guidelines to indicate when a smaller church can still continue to call itself a church or when perhaps it should think seriously of radically changing its program and operation, or even disbanding or amalgamating with another congregation.

If this study were to suggest a model which may best describe the operation of the small church it would be that of the "family." 1 But just as families vary radically, so do small churches. Hence this study seeks to look at those characteristics which the large spectrum of small churches seems to have in common. It would appear that these characteristics are also very similar to those present in nuclear and extended families, hence the comparison seems to be valid.

IRichard Rohr, "Building Family," 8 Sojourners (January 1979): 20-22. 
CHAPTER I

THE CHURCH AS FAMILY

\section{Contemporary Theological Views}

Family Style Community in the Church

In looking at the small church it is interesting to see how recent theological writers have laid a foundation upon which investigators of the characteristics of the small church can build a strong supportive framework. If one thing unites these various concepts it is that of the place of 'personal relationships.' It is this one great trait which really distinguishes the small church (or single, extended, small group) from a large church (many smal1 groups meeting together).

M. Douglas Meeks says of the theological position of Jurgen

Moltmann:

Moltmann's theology is preeminently a trinitarian theology which provides a consistent trinitarian view of the church. .. I believe that Moltmann's main contribution to practical theology is that he places it in a trinitarian context.

The 'family' relationship within the Trinity is taken by Moltmann as the norm in considering the relationship between the Persons in the Trinity and those being called into the Kingdom of

IM. Douglas Meeks, "Moltmann's Contribution to Practical Theology," ed. and trans. Theodore Runyon, Hope for the Church (Nashville: Abingdon, 1979), p. 61. 
God: And in relationships among the community members themselves

the pattern of the Godhead is once again the norm. Moltmann can say:

God as love, however, can only be witnessed to and experienced in a congregation small enough for members to know each other and accept one another as they are accepted by christ.

It is the Trinity which permeates all of Moltmann's theology, and in examining the participation of the Church in the history of God, he says: "In the movements of the trinitarian history of God's dealings with the world, the church finds and discovers itself in all the relationships which comprehend its life."2

Karl Barth found his basis for the doctrine of reconciliation in the Word, agreeing with Schleiermacher that all theology will be church theology, yet saying that the church is not God's first word. Jesus Christ is God's first word. ${ }^{3}$ But the danger exists for some to suggest that the church, as the proclaimer of Christ, is authorized to be the last word of God. Moltmann helps meet this problem with his theology of reconciliation and mediation based on the concept of the Trinity. Yet Barth and Moltmann are very close together in their view of the intimate involvement of God (the Trinity) with this world

Jurgen Moltmann, "The Life Signs of the Spirit... . " ed. and trans. Theodore Runyon, Hope for the Church, p. 40.

2 Jurgen Moltmann, The Church in the Power of the Spirit (New York: Harper and Row Publishers, 1975), p. 64, cf. Karl Barth, Church Dogmatics, vol. 1 part 2 (New York: Charles Scribner's Sons), p. 124.

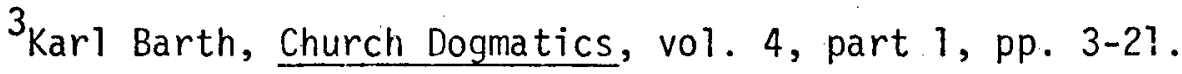


and His people. 1 Schleiermacher is also very logical in linking the operation of the Trinity with the ministry of the Church. ${ }^{2}$ Moltmann's "theology of hope" is not supporting some idea of a totally futuristic "dream time" period of bliss--although it involves the eschaton; nor is it to be equated with the liberal golden age to be ushered in by radical social reform--yet tireless service for others is involved. Rather he sees hope for the church residing wholly in Christ and the salvation He has accomplished for us:

In intention the statements about the church--'the body of Christ', 'the house of God', 'God's people', 'the communion of saints', etc.--are also directed towards the person of Jesus and his history, by way of the christological titles on which they depend. . . . It is only the present realization of the person that brings the church into its necessary and hopeful non-contemporaneity with the present. ${ }^{3}$

Moltmann sees the hope of the church residing in the salvation and reconciliation provided by the Persons in loving

1 Note this rather radical statement by Barth: "First and supremely it is God who exists for the world. And since the community of Jesus Christ exists first and supremely for God, it has no option but in its own manner and place to exist for the world." Karl Barth, Church Dogmatics, vol. IV, part 3 (Edinburgh: T. \& T. Clark Ltd.), pp. 762-764.

2 "For unless the being of God in Christ is assumed, the idea of redemption could not be thus concentrated in His Person. And unless there were such a union also in the common Spirit of the Church, the Church could not thus be the Bearer and Perpetrator of the redemption through Christ. Now these exactly are the essential elements in the doctrine of the Trinity. ...." Friedrich Schleiernacher, The Christian Faith, vol. 2 (New York: Harper and Row, 1963), p. $73 \overline{8 .}$

3 Moltmann, The Church in the Power of the Spirit, p. 67. Note Douglas Meeks' definition of what Moltmann's theology of hope is not; Meeks, pp. 67, 68; cf. Karl Barth: "It may be a theology of hope in the glory of the children of God, a glory that is already revealed in the resurrection of Jesus Christ and is to be revealed anew at the very last, for the benefit of all creatures and, therefore, also for theology and its work." Evangelical Theology (Grand Rapids: Wm. B. Eerdmans Publishing Company, 1979), p. 155. 
relationship within the Trinity. ${ }^{1}$ : As personal relationships form the basis of God's dealing with His church and in congregations dealing with each other and with the world, Moltmann sees this best exemplified in small communities forming a loving family fellowship patterned after that within the Trinity itself.

For this reason everything depends on the emergence of sma 11, freely constituted, comprehendible communities in the large, uncomprehendible districts of the church. Community exists only when persons really know each other. God as love is experienced not in large organizations and institutions but in communities in which people can embrace each other. 2

Moltmann notes the recent strange developments in Germany where small voluntary Christian groups are springing up and revealing a life not found in the state churches. ${ }^{3}$ He sees the heritage of these modern developments lying in the Radical Reformation rather than the truncated Lutheran and Calvinist Reformation, which unfortunately and fatefully set the stage for the diminution of the place, power, and prestige of the local congregation. ${ }^{4}$

Edward Quinn notes this same recommendation of the development of "basic communities" ("primal". communities for Dudley) in Karl Rahner. ${ }^{5}$ Rahner is thinking more in the area of social action by

JJurgen Moltmann, The Open Church (Philadelphia: Fortress Press, 1978), pp. 85, 86.

2 Ibid., p. 125.

${ }^{3}$ Ibid., p. 122. A situation foreseen by Emil Brunner as far back as 1953; Emil Brunner, The Misunderstanding of the Church (Phi1adelphia: The Westminster Press, 1953), pp. $117-118$.

4 Moltmann, The Open Church, p. 117.

${ }^{5}$ Karl Rahner, The Shape of the Church to Come (London: SPCK, 1974), p. 7. Cf. Dudley, Making the Small Church Effective, pp. 3245. 
many small communities formed at the "grass-roots" level by lay. people with a burden of diakonia. He says they should be recognized as legitimate churches amongst the sisterhood of churches in the Catholic parish, with married leaders if this is decided by the community. 1

Anders Nygren, taking Paul's analogy of the church as the Body of Christ, builds a powerful case for the complete unity of the church (whether referring to local congregations or universal). ${ }^{2} \mathrm{~A}$ unity he sees founded in love between the various members making up the church. ${ }^{3}$ Yet in the light of Moltmann's view that love and community going together can really only be experienced in a group or situation where people really know one another and interact intimately together. One wonders then how an individual congregation (orie Body, or unit suggests, Paul and Nygren) which is above the size for all the "members" to know and relate to one another in family fashion can really in practise experience loving community as a unit or church? In the context of establishing the house church as the very life blood of the universal church in an Anglican situation, John A. T. Robinson says:

The visible Church of Christ is a congregation of faithful men, in terms of the local unit, and then think of the universal Church as a federation of these units. But, while the Church is always the great Church, it can nevertheless, and must, be embodied in units which can still be described

I Ibid., p. 109.

${ }^{2}$ Anders Nygren, Christ and His Church (London: SPCK, 1957), pp. $93-96$.

3 Ibid., pp. 110, 111. 
as 'the Church'--the Church as it finds expression 'at Corinth', 'in your house.' These units are not simply bits of the Church; they are the body of Christ in its totality, as it exists in this or that of its cells. Each cell is a microcosm on its own scale perfectly reproducing the whole. This is an immensely important point for the doctrine of the local Church, and it is the truth which Congregationaljsm and our own Articles have so magnificently grasped.

It seems, therefore, that the criterion that some would require of "sufficient numbers" has really little to do with what constitutes a Christian community under the name of "church." Rather church is present when a gathering forms one body meeting as a family of the children of God to worship and celebrate their redemption and fellowship with the saving, loving members of the Trinity. Helmut Thielicke puts it this way:

. . I believe the church for a far different reason. It is because the word of the Lord grips me there and leads me to the source of life, and because at a stroke two things now become clear to me. The first is that I have heard this creative and transforming word only there, and only there can I hear that this word may be heard only in the fellowship of Christians, that is, where two or three are gathered in his name. And a second thing also becomes clear: his people are found wherever this word is spoken. There the Lord will be 'in the midst of then'; there the miracle of the church will take place.2

\section{A Tripartite Existence}

By tripartite I mean the threefold characteristics which make up a church: (1) preaching, witnessing, the Word (kerygma); (2) fellowship, community, both with believers and unbelievers

1 John A. T. Robinson, On Being the Church in the World (Philadelphia: The Hestminster Press, 1960), p. 83. 1968), p. 236.

${ }^{2}$ Helmut Thielicke, I Bel ieve (Philadelphia: Fortress Press, 
(koinonia); and (3) service, suffering for others (diakonia). Moltmann sees that "the unity of the universal church can be organized through synods and offices of leadership only when unity already exists at the grass roots level. "1 Hence the local church community becomes the bulwark and source of unity for the whole Christian church and Moltmann only sees unity developing when the Reformation impetus is still maintained. This impetus he sees as composed of three strands: "the justifying faith, the universal priesthood of all believers, and the mature, responsible congregation." 2 The three characteristics of the church are really the practical operation of the three strands in the Reformation: (1) preaching and witnessing is the testifying to justifying faith; (2) fellowship and community is the living out of the universal priesthood of all believers, and (3) service and suffering for others is the life of a mature, responsible congregation. The whole unified community then is geared for the work of mission in conformity with God's work of mission for the world. ${ }^{3}$

In looking at local communities it would seem that at least superficially kerygma can be exercised by and in groups whatever their size, e.g., a large number of conversions at Billy Graham rallies where thousands of people are assembled. Further research,

1 Moltmann, The Open Church, p. 116.

2Ibid., pp. $116,117$.

3Lesslie Newbigin, The Open Secret (Grand Rapids: Wm. B. Eerdmans Publishing Company, 1978), pp, 1, 2. Newbigin, like Moltmann, finds his basis for the church and mission in the Trinity, see e.g., pp. 28-31. Cf. John R. W. Stott, Christian Mission in the Modern World (Downers Grove, 111.: Intervarsity Press, 1977), pp. 2125. 
though, may possibly indicate more success in small group and celltype preaching situations. Yet it would seem that diakonia can only be exercised in cell groups--they may be very small or fairly large and a committed large church can operate reasonably well a number of efficient service cells, with each individual member also supposediy serving his neighbors. The very small congregation may be limited in what it can do collectively, but even the smallest can operate at least one or two small cells in service as well as individual labor. Undoubtedly the small church has in potential and practise a much greater opportunity to involve a larger proportion of its members than a large church. ${ }^{1}$ But in the third area of koinonia it would seem that meaningful fellowship is only possible in a group within a certain size limit. ${ }^{2}$ This means that a large church, above this limit, is at a serious disadvantage when it comes to koinonia and cari really only maintain it in the subcells within the congregation and hence in all honesty could find it difficult to call itself a unit or one body of Christ. Both individual churches and conferences or parishes face a similar problem and both try to meet it by the use of organizational structure and an increasing reliance upon a hierarchy. History would seem to bear out the fact that as size increases and fellowship drops, hierarchical control structures increase power and influence. Almost inevitably a rift grows between clergy and laity--those making the real decisions and those carrying out and effected by the decisions. Both Barth and Moltmann see that

' See chapter 2 .

2 Ibid. 
historically this change dramatically took place in the Constantinian era when, as Moltmann says:

The fellowship of Christ became the religion of society. The church forfeited her special form and distinct visibility as a fellowship and became a part of the public order. . . . The division between clergy and laity was finalized. Faith was exercised through participation in the religious ceremonies sponsored by the church. Fellowship in the church was replaced by gradations of communion with the church.

Not only did the loss of fellowship result in the elevating of the professionals over the laity, but the effect was passed on to the other two areas of church operation--witness and service.

The gospel witness became an official proclamation handed down from higher authorities. With this came also the deterioration of Christian diakonia practised by the congregation. It was replaced by public welfare and private charity. The Christian mission of evangelization was also lost.2

This does not mean that largeness is necessarily wrong and smallness right, ${ }^{3}$ but history should at least caution us to the danger to the church when increasing size destroys true fellowship in a worshiping group.

The small church has an advantage over the large church in that operating as a unit, or as a united family--the one body of Christ--it can experience koinonia or fellowship among each of its members--an event practically impossible in a group larger than 200-

I Moltmann, Hope for the Church, p. 39; cf. Karl Barth, Community, State, and Church (New York: Doubleday and Co., 1960), pp. 157-160.

${ }^{2}$ Ibid. 710.

${ }^{3}$ Cf. Karl Barth, Church Dogmatics, vol. 4, part 1, pp. 709, 
300 members. $^{1}$ Of each of the three areas of church activity, koinonia should be able to reveal the gospel best of all, for kerygma spells out the Gospel, and diakonia is the Gospel in action, but koinonia is the Gospel in essence--it is reconciliation involving intimate personal relationship.

Therefore, the nature of the church as the reconciled community is inseparable from the function (mission) of the church as the minister or agent of reconciliation. The being of the church and the calling of the church merge into one under the single reality of God's reconciling activity in Jesus Christ. 2

The small church, even down to just a few members, building upon its "natural" characteristic of koinonia, can work at strengthening its kerygma (preaching and witness) and diakonia (service and ministry) just as the Gospel when experienced also results in it being witnessed and ministered.

\section{A Total "Charismatic" Community}

We noted earlier how the fellowship (koinonia) in the community was intimately related to the belief in the priesthood of all believers. Hans Kung ties together the Church as the people of God, as the body of Christ, as a spiritual building, as a temple of the Holy Spirit and then says: "The whole people, filled by the spirit of Christ, becomes a priesthood set apart; all Christians are

${ }^{1}$ See chapter 2, where discussion is given to the one-familyfellowship "glue" which begins to come apart in an extended group larger than about 200-300 people.

${ }^{2}$ Arnold B. Come, Agents of Reconciliation (Philadelphia: The Westminster Press, 1964), pp. 48, 49. Cf. Karl Barth, Church Dogmatics, vol. 4, part 2, pp. 642-647. 
priests." 1 Hence I am referring to a Spirit-filled and Spirit-lead community when I talk of it as "charismatic." It takes place when, as Kung says:

The Spirit of God turns man away from the world and from himself and places him under God's grace. The reign of the world is finished, the true reign of Christ begins. The Spirit of the Lord takes possession of us, and opens to us intransient things, life and the future. He gives us a recreated childhood: a new freedom from sin, law and death in peace, joy and life. But the Spirit is only given to the individual through being given to the community, the church.2

The source of charismatic fellowship in the church is found in that communion we have with God through the Third Person of the Trinity as noted by Arnold Come:

The reality of this rootage of all human creaturely togetherness in reconciliation with God is beautifully and precisely expressed in Paul's Trinitarian benediction, 'The grace of the Lord Jesus Christ and the love of God and the fellowship Kononia of the Holy Spirit be with you all" (2 Cor 13:14). Grace and love between God and man, and among men and creatures are inseparable from deep, personal, spiritual community with God. 3

Through the Holy Spirit, being reconciled with God by the blood of the Lamb, we have fellowship with Him and with fellowreconciled brethren in the family community of the Church. Hence it is the presence of the Spirit in the Church which fosters fellowship and being reconciled. He does not leave us powerless but gives to the Church charismatic or spiritual gifts. ${ }^{4}$ Kung prefers to call them "charisms" and says of them: "The true charism is not simply a

IHans Kung, The Church (New York: Sheed and Ward, 1967), pp. 370,371 .

$$
\begin{aligned}
& { }^{2} \text { Ibid., p. 162. }{ }^{3} \text { Come, p. } 42 . \\
& { }^{4} \text { See Rom 12:4ff., Eph } 4: 8 \mathrm{ff} .
\end{aligned}
$$


miracle; it is something in the service of the community, giving a sense of responsibility towards the community and the desire to edify and benefit it." 1

No member of the body of Christ is left out of the gift distribution by the Holy Spirit; all receive a "charism: and should use it to nourish the community and the mission of the community in the world surrounding it. ${ }^{2}$ A large church with a more structured organization can usually through the structure place gifted people in service positions, but a small church more loosely organized and often lacking a "critical mass" ${ }^{3}$ is often 111 -educated and 117 equipped to recognize, develop, and utilize the spiritual gifts distributed within its ranks. The study of the subject of spiritual gifts and the Holy Spirit Himseif has been discredited in the past because of a connection with "enthusiasm," 4 yet recent scholariy work seems to present it more in its important New Testament place. ${ }^{5}$

${ }^{1}$ See Kung, p. 182.

${ }^{2}$ See Moltmann, The Church in the Power of the Spirit, pp. 294314. Cf. Scheiermacher, pp. 574-578.

${ }^{3}$ More will be said on this concept in chapter 2.

${ }^{4}$ Moltmann and Kung obviously disagree in this area, yet Kung has an interesting insight into Luther's opposition to the enthusiasts and how it came about that they in the end triumphed over him. Incidently, Kung places Seventh-day Adventists squarely in the "enthusiast" tradition. Kung, pp. 194-203. Cf. Moltmann, The Open Church, pp. 117, 118.

${ }^{5}$ E.g., Thomas F. Torrance, Theology in Reconstruction (Grand Rapids: Wm. B. Eerdmans Publishing Company, 1966), pp. 240-258; Conflict and Agreement in the Church, vol. 2, "The Ministry and the Sacraments of the Gospe1" (London: Lutterworth Press, 1960), pp. 1357. An excellent paper is entitled "Christ's Ministry through His Whole Church and Its Members," in Encounter 25 (Winter 1964): 105129. See also Ray S. Anderson, Historical Transcendence and the 
Although the whole church should benefit from this neglected area being examined, the most dramatic changes should be seen in the small church, which also is more "pro-charismatical" in its operation, more flexible, and more open to potential change. But the Gifts are not given just to edify the individual or the congregation. If we agree with Newbigin' that mission is the primary task of the Church, then the Gifts within the church are to be used for the world. Even prophery which Paul upholds as edifying the believers (1 Cor 14) has ever been a primary tool in evangelism (e.g., the Scriptures themselves). With the majority of Christian churches being in the smallchurch category, ${ }^{2}$ it is vital that the small church see itself as a Spirit-filled, gifted community open to the world, with the message of reconciliation. ${ }^{3}$ And in this plea by many recent theologians for a "grass roots," "basic or primary group" development in the successful "church" of the future, could not the small-church leaders and members hear the voice of the Spirit pointing out the priceless treasure in the intimate family fellowship of the small-church

Reality of God (Grand Rapids: Wm. B. Eerdmans Publishing Company, 1975), pp. 227-251.

$1_{\text {He quotes from the Willingen Conference of the Interna- }}$ tional Missionary Council (1952): ". . there is no participation in Christ without participation in his mission to the world." Newbigin, p. 1.

${ }^{2}$ Chapter 2 looks at this in more detail, but the Adventist Church has over three quarters of its churches with less than 200 members and well over half with less than 100 . In these characteristics it is not very much different from other Christian churches.

$3_{\text {I feel that it is for this reason that Moltmann (Hope for }}$ the Church, pp. 38, 39, and The Open Church), Rahner (The Shape of of the Church, p. 93), and Karl Barth (C.D. 4; 3: pp. 762-795) a17 call for an "Open Church" in the future, a church "for the world." 
community--yet a fellowship that will only be mobilized as each member sees himself as a minister called to serve his brethren both within the community and outside it.

In the next section I would like to consider the theology of the New Testament relative to the small church, particularly as it relates to the picture of the church as a family fellowship.

\section{A New Testament Theological View}

The Family of God

Although the Greek word for family (patria), when used specifically for the "people of God," seems to be used only in one place in the New Testament (Eph 3:15), there appears no doubt that under a number of "related" metaphors, the church as the "family of God" ranks with other significant terms such as: "the body," "the community," "the bride," etc. ${ }^{1}$ This text in Ephesians is somewhat controversial, yet commentators seem to agree on such major concepts as "oneness" in Christ, "a unity of the church below with beings in heaven above," and the redeemed community now bearing the one name of the Father. ${ }^{2}$ The passage reads: "For this reason I bow my knees

\section{${ }^{1}$ Compare Jamieson, Fausset, and Brown, Commentary on the} Whole Bible (Grand Rapids: Zondervan, 1970), p. 1085. Also PauT S. Minear, Images of the Church in the New Testament (Philadelphia: The Westminster Press, 1960).

${ }^{2}$ T. K. Abbott, A Critical and Exegetical Commentary on the Epistle to the Ephesians and to the Colossians (ICC) (New York: Charles Scribner's Sons, 1905), pp. 93, 94, sees great significance in the lack of the article before patria and therefore discounts the translation "the whole family. "William Hendriksen, New Testament Commentary (Grand Rapids: Baker Book House, 1967), pp. 167-170, disagrees and prefers the AV rendering. Others take a mediating position. 
before the Father, from whom every family in heaven and on earth is named: (Eph $3: 14,15 ;$ RSV).

Although the grammar may tend to support the RSV translation "every family," the context would tend to support the unity idea expressed in the "whole family" found in the AV. " The central point, though, is that all bear the one name, ${ }^{2}$ and that now in the family of God, each member partakes of the riches and blessings of that family, in particular the gift of the Holy Spirit through whom Christ dwells in the heart of the believer. ${ }^{3}$

It seems that three basic points can be drawn from the passage: (1) The faithful servants of God, whether on earth or in heaven, whether angels or men, are looked upon as forming one family. ${ }^{4}$ (2) All in this family bear the one name--that of the

${ }^{1}$ See Charles Hodge, Commentary on the Epistle to the Ephesians (Grand Rapids: Wm. B. Eerdmans, 1966), pp. 179, 189, but compare: Francis Foulkes. The Epistle of Paul to the Ephesians (Grand Rapids: W'm. B. Eerdmans, 1963), pp. 101, 102.

${ }^{2}$ Schrenk points out that all of God's creation in not primariiy in view here in the "whole family." He is not principally "Father of all" but rather (always in Ephesians) "the Father of Jesus Christ." "It is not as the primal father in the Greek sense, but as the revealed Father in Christ, that God has a relation to every patria. . . " Gerhard Friedrich, Theological Dictionary of the New Testament (Grand Rapids: Wm. B. Eerdmans, 1970), 5:1019.

3 Eph 3:16, 17.

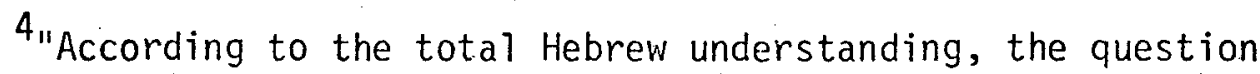
of the nations is viewed from the standpoint of the family and the father. .. . The heavenly and the earthly are constantly interrelated. . : . From the Father of Jesus Christ our gaze is directed to every patria which finds the motive power of unity in this Father." Ibid., p. 1018. Cf. Heb 12:22-24, and Paul Minear, "The Mystery, the Grace and the Power: Eph 3:1-21," Reformed World 34 (1977): $342-348$. 
Father. This strengthens the unity concept. All are now counted as of the one lineage. The Scriptures seem to make little distinction between the "natural born" (perhaps the angels in heaven, or any other created beings who have never fallen) and the "adopted children" (those "bought back" by the shed blood of the Lamb of God). 1 (3) All of the family wealth and blessing, bestowed by the Father upon His children and heirs, is now showered upon His redeemed children upon the earth. The pinnacle of the gifts given to the members of the family is the giving of the gift of Christ to dwell in the believer's heart through faith and by the power of the Holy Spirit.

Paul explains in this passage the glorious blessings purchased by the Lord Jesus Christ and how the gift of adoption into the family of God, while hidden in the past, has now been revealed. No longer is God's salvation or blessing to be locked up or restricted by any national or ethnic boundaries, for now the mystery of a redemption, open to all, has been revealed (Eph $3: 8$ ). The author has developed in this chapter his revelation of the mystery once hidden from the "sons of men" (the human "family"), the notion that now through the grace of God in Jesus Christ all the "sons of men"-whoever they might be--can be included in the "family of heaven and earth," and that now the church is to be God's instrument in bringing this glorious revelation of the gospel to others, not only through the preaching of Christ but also through the manifestation of the Tove of Christ actually seen in the church itself as it partakes of

TFor example, Heb 12:22-24. 
the "fulness of God" (Eph 3:19). ${ }^{1}$ Paul concludes the chapter with a doxology founded upon the fact that there is no limit to what God can do in and through His people.

It would seem that Paul is looking upon the church--whether composed of Jews, Gentiles, or mixed--as now appropriating God's promises once made to his ancient people of Israel to the new Christian family being raised up, and that now God's people are those called out by faith in Jesus Christ.

The figure of the church as the "people of God" is a major one in the New Testament, although some differences among:cominentators does seem apparent, mainly concerning the question as to what extent the Christian church has or has not displaced national Israel as God's chosen people. Hans Kung recognizes the importance of the figure to the NT church:

The idea of the people of God is the oldest and most fundamental concept underlying the self-interpretation of the ekklesia. Images such as those of the body of Christ, the temple and so on, are secondary by comparison.2

Kung declares that the apostolic church clearly realized that it was the true Israel, the true people of God, and had no hesitation in applying the central idea of the people of God to themselves. ${ }^{3}$

'On this common but problematic use by Paul of "fulness" (pleroma), Albert Barnes suggests: "It means here, 'that you may have the richest measures of divine consolation and of the divine presence; that you may partake of the entire enjoyment of God in the most ample measure in which he bestows his favours on his people.'" Notes on the New Testament, vol. 8 (Glasgow: Blackie and Son, n.d.T, p. 64 .

2 Kung, pp. $119,120$.

${ }^{3}$ Ibid. Unfortunately, Kung weakens his position considerably, so it seems to me, by also attempting to maintain national, racial Israel as the true people of God through this Christian era. 
Minear follows a pattern similar to Kung's by tracing the people of God through the OT and then into the Christian church under the New Covenant, but he seems closer to the biblical perspective in noting little radical change in God's attitude toward his loyal people, whether under the OT or NT eras.

So strong is this sense of solidarity that one must conclude that the continuity between the two Testaments is grounded in the fact that both tell the story of how the same God fulfills his covenant promises to the same people. It is significant that no change of name was considered necessary to make room for the new community. The Israel to whom the gospel comes and through whom the mission to the world is accomplished is the same Israel to whom the promise had been given.

Accepting the fact that the NT takes the title "the people of God" and, without an apology, applies it to the Christian church, let us look a little closer at some of the extensions of the family ana logy.

The Church as Sons and Daughters

In many places the NT calls the believer a "son" or a "child" of God. A number of different Greek words are used wi thout a great deal of difference in meaning, often they are clearly synonyms. ${ }^{2}$

He is far from alone in this and, like most, he is virtually dependent on a partisan interpretation of Rom 9-11. Ibid., pp. 132-150.

1 Minear is stronger in his support of the concept of the one people of God--Israel--than Kung, although he too finds a place for biological and racial favor for national Israel in the Christian era. Images of the Church in the New Testament (Philadelpha: The Westminster Press, 1960), p. 72. In addition he notices many of the 01d Testament's symbols, rituals, and articles being taken over and applied to the church in the Christian era.

${ }^{2}$ Oepke classifies them as synonyms. See TWNT, 5:636. Cf. G. Abbott-Smith, A Manual Greek Lexicon of the New Testament

(Edinburgh: T. and T. Clark, 1964), p. 334. 
Hence a theological position based on differences between the words would be built on a rather tenuous foundation. Although the word "daughter" is only rarely used together with "son," in reference to the believing community (e.g., Acts 2:17, quoting from the LXX of Joel 2:28-32), it is accepted that the three ma in words ("son" or "child," masculine and neuter, respectively) when used of the community, generally do not involve any limitation to the male sex. In most contexts, I would prefer to render all three terms (hios, teknon, and paidion) as "children," "men and women," "brethren and sisters," or "sons and daughters," etc." The use of this "offspring" language in the NT comes right out of the OT tradition and must have been very familiar to both Jews and early Christians. The "sons of faith" were in the process of being called out of "natural" Israel and from amongst the Gentiles. ${ }^{2}$

I would like to examine the concept of sons and daughters (or children) of God under the subheadings which seem to bring out some of the main characteristics dwelt upon by the NT.

\section{Children like their Father}

Jesus employs this image, but in the process raises, for us, a theological problem. "Just how much and in what way do the children resemble the Father?" In the beatitudes the Lord said:

This is probably a basic point in the "liberated pharisee," Paul's statement in Gal 3:28, 29 ". . . there is, neither male nor female: for ye are all one in Christ Jesus. . . "

${ }^{2}$ This was not an entirely "new" concept for some of the prophets had hinted at it; e.g., Isa 56, 50, 66; Hos 2:23. 
"Blessed are the peacemakers: for they shall be called the children of God" (Matt 5:9). This should be connected with verses $43-48$ at the close of the chapter, ". . . Love your enemies . . that ye may be the children of your Father. . . be ye therefore perfect, even as your Father which is in heaven is perfect."

These verses are significant to the role of the believing community (as well as the individual Christian) as family, for a basic characteristic of a healthy and happy family is some successfut method of conflict solving. Here in Matt 5:9, Jesus is speaking of those who make peace (not pacifists or non-resistors, but those who actually bring about peace by overcoming evil with good). ${ }^{1}$ It is those who work actively toward harmonization, toward the strengthening of friendships, and the avoiding of petty bickering who display the divine nature of love and who are called sons of God by those who observe them. ${ }^{2}$ It does not mean that they will suppress all conflict or open discussion of "hot" issues (in fact, they may work towards encouraging open discussion), ${ }^{3}$ but their aim will be that of making peace and advancing the cause of God.

The concluding verse of the chapter (Matt 5:48) presents the "impossible possibility," yet, as David Hill has said, "The

'David Hill, The Gospel of Matthew (London: New Century Bible 0liphants, 1972), p. 173.

${ }^{2}$ Ralph Earle, The Wesleyan Bible Commentary, vol. 4 (Grand Rapids: Wm. B. Eerdmans, n.d.), p. 37. Cf. T Thess 5:23; Eph 2: 14-18. Also Philip A. Micklem, St. Matthew (London: Methuen and Co. Lto., 1917), p. 39.

${ }^{3}$ For example see Speed Lees and Paul Kittlaus, Church Fights (Philadelphia: The Westminster Press, 1977), pp. $\overline{47,48 .}$ 
emphasis is not on flawless moral character, but on whole-hearted devotion to the imitation of God--not in the perfection of his being, but of his ways." 1 Jesus is not talking about the "sinlessness" of Godrow being perfectly attained in his children, but rather the positive aspects of God's perfection--what he is in his dealings with us:

The perfection of God in Matthew 5 is that grace of God which goes beyond mere justice and goes out to the evil man, and not merely to the good man; to the unjust man, and not merely to the just man. In distinction from publican and heathen, God loves those who do not love Him, and in distinction from scribe and Pharisee who would not lift a finger, said Jesus, to help the burdened, God loves the sinful and needy, the evil and the unjust, sending them rain and sunshine.?

Those who are a part of the family of God have a standard of conduct which is "out of this world." Surely the Lord Jesus, in the sermon on the mount, is saying nothing less than this, but it is a conduct done in faith, perhaps with flaws, yet done in a similitude of the divine pattern and, hence, partaking of the likeness of the Father's perfection. ${ }^{3}$

Luke renders Jesus' plea as a call to mercy (Luke $6: 35) .4$ Then to the immensely high standard "perfection" and "mercy"--as the

THill, p. 131.

2 James Daane, "The Perfection of God," The Reformed Journal $8(1958): 5$.

${ }^{3}$ Daane wrestles with this problem of Jesus' high ideals for his people which he suggests permeate the whole of the Sermon on the Mount, and concludes by saying: "The perfection of God is His gracious conduct toward sinners, the children of God who have been fashioned and shaped by this gracious divine perfection must reveal this same perfection in their conduct toward their enemies." Ibid., p. 6 .

${ }^{4}$ See comment by W. C. Allen, Gospel According to St. Matthew (ICC) (Edinburgh: T. and T. Clark, 1957), pp. 55, 56 . 
Father is both of these--Peter now adds for them to be "holy ones" as God is "holy" (1 Pet 1:14-16). There is to be a "separation" (the basic meaning of "holy") from all defilement and sin, but note:

The idea of "separation," in so far as it continues to flavour the word, is separation to God rather than separation from the world; naturally separation to God means separation from $\sin$ because God and sin have no common meeting point. Thus understood it teaches a positive rather than a negative conception of conduct.

The children of God are not to isolate themselves from the unbelieving world. Being holy does not imply being "cloistered." On the contrary they are now, like Israel of old, to be God's channel of light and salvation to those surrounding them who are yet outside the family (1 Pet 2:9-12).

With this development by Peter, we are led into the next section dealing with the "called-out-remnant" characteristics of God's family, but before proceeding I would like to conclude this portion by returning to the basic words of Jesus in the Sermon on the Mount and note Suzanne de Dietrich's summary:

If in the Sermon on the Mount we have merely a system of ethics, or of a self-sufficient morality, then its demands must overwhelm us. It has often and rightly been reproached for lacking realism, for demanding the impossible. The Sermon on the Mount is "good news" only if we receive it from. the mouth of the One who himself lived it and who, by his grace, desires to live it again in us, to transform us into his image, to make us authentic sons of the Father. Otherwise, it remains for us only a judgment, for it lays bare all the avowed or hidden refusals of a heart which is in rebellion against the divine law. But it is also a call

IErnest Best, I Peter, NCB (London: 01 iphants, 1971), p. 86 compare Elmer G. Homrighausen, The Gospel According to St. Matthew, The Interpreters Bible, vol. XII (New York: Abingdon Press, 1957), pp. 102, 103. 
and a promise, a glorious opening on the coming kingdom of which, by faith, we are the children.?

Children by faith

I look at this suggestion from the viewpoint of three passages of Scripture: (1) In Matt 8:5ff, the story of the healing of the centurion's servant (or son) indicates that one is not a member of God's family by lineage, race, social, or economic status, or even by zealous striving to keep all the precepts of the law. Rather, it is by accepting by faith the deliverance offered in grace by the Lord. 2 This was a radical idea to the minds of Jesus' hearers and it seems to have remained radical ever since.

There are some interesting steps in the narrative which are quite relevant to the situation of the family membership today: First, the petitioner has no natural grounds or rights to approach the Lord, and he frankly faces this fact honestly and confesses it. Second, he comes to the Lord anyway. In spite of seeing no legal, national, ethnic, social, or any other ground for acceptance, he still comes and pleads for the naturally impossible. Yet this act of faith, like all acts of faith, is not completely baseless, for he has heard rumors and reports about Jesus' ability to heal, and

7 Suzanne de Dietrich, The Gospel According to Matthew, LBC (Richmond, Virginia: John Knox Press, 1961), pp. 39, 40.

2 "We are brothers and sisters in the house of the Father, who willed us to be his children. . . The Incarnation deepened this filiation and fraternity with the Son. Already in eternity we were children of God in the Son. Now in history we express the import of this fact in time and space, in the flesh and in the spirit." Leonardo Boff, Liberating Grace (New York: Orbis Books, 1979), p. 190. 
upon this tenuous evidence he places his faith. 'Third, he confesses his complete unworthiness, based on a true insight into his sinful condition and moral insufficiency. ${ }^{2}$ Fourth, he puts his faith into action by saying that the word of power and authority, even over sickness, lay with Jesus, and he backed up his stand by giving an illustration supporting his position. Such faith, said Jesus, would be shown by countless others who would come into God's family and the "natural born" without faith would be disinherited and rejected.

The passage seems to be clearly saying that the ground of entry to the family of God is one based upon faith and not natural birth or privilege, hence all of God's children are adopted and none have a natural right to be at the great eschatological party of the Kingdom with Abraham.

(2) In Rom 9-11, Paul elaborates upon the relationship between Jew and Gentile. In spite of what many commentators seem to suggest, I would propose that the passage maintains Paul's basic thesis that the sole foundation of acceptance into the family of God is by faith and adoption, not by race, "natural descent," or any other human "right," worth, work, or devising. ${ }^{3}$ Nor does the passage demand a double predestination as the ultimate definitive for salvation, and so displace faith. ${ }^{4}$ Hence a position which makes

$1_{\text {de Dietrich, pp. 51, } 52 .}$

${ }^{2}$ Micklem, p. 74; Hill, p. 158. 3E.g., Rom 9:23-33.

${ }^{4}$ See Everett F. Harrison, "Romans," The Expositors Bible Commentary (Grand Rapids: Zondervan Publishing House, 1976), 10:107. 
Paul's a dogmatic assertion, unique to the rest of his teachings, in this passage (particularly at the climax in ch. 11:25, 26ff.) of some future miraculous end-time transformation of the whole nation of Israel (or for that matter, any other group along racial, national, or ethnic lines), must be viewed with some skepticism. ' The olive tree in ch. 11 clearly seems to be spiritual Israel, and the criterion for remaining on, or being grafted into, it is belief in the Lord Jesus Christ as Messiah and Saviour. ${ }^{2}$ Hence being a part of the family of God is not ultimately determined by an arbitrary decree by God, nor by birth or nationality, but rather by God's call in mercy open to all who will in faith repent and accept Christ as Lord and Saviour.

The situation is relevant to us today when long-established members of a small church look upon themselves, with their higher moral, health, and religious standards, as somehow having an

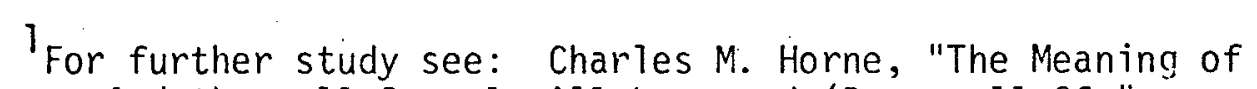
the Phrase, And thus all Israel will be saved (Romans 11:26," Journal of the Evangelical Theological Society 21 (1978): 329-334; R. C. H. Lenski, St. Paul's Epistle to the Romans (Columbus, Ohio: Wartburg Press, 1945), pp. 695-737; Karl Barth, The Epistle to the Romans (New York: Oxford University Press, 1977), pp. 412-417; Johannes Blauw, The Missionary Nature of the Church (Grand Rapids: Wm. B. Eerdmans, 1974), p. 101; John Calvin, EpistTe to the Romans (Grand Rapids: Wm. B. Eerdmans, 1947), pp. 436, 437; G. C. Berkouwer, The Return of Christ (Grand Rapids: Wm. B. Eerdmans, 1975), pp. 323358; Herman Ridderbos, Paul: An Outtine of His Theology (Grand Rapids: Wm. B. Eerdmans, 1977), pp. 358, 359. Compare George S. Worgul, Jr., "Romans 9-11 and Ecclesiology," Biblical Theological Bullet in 7 (July 1977): 99-109; Anders Nygren, Commentary on Romans (Philadelphia: Fortress Press, 1967), pp. 399, 400; Johannes Munck, Christ and Israel (Philadelphia: Fortress Press, 1967), pp. 132-137.

$3: 1-12$.

${ }^{2}$ Rom $11: 19-26$. Cf. 1 Pet $2: 6-10 ;$ Eph $1: 3-14 ; 2: 1-22$; 
advantage on the salvation ladder or in God's list of favored ones. A long family heritage of church membership cannot keep one from being pruned off the olive tree of spiritual. Israel when true saving faith is absent. This passage teaches us today that family lineage, whether in national or spiritual Israel, counts for nothing when personal faith is not placed in the Saviour. A Christian heritage can provide a positive environment, a rich educational climate for the Gospel (e.g., Rom $3: 1 \mathrm{ff} ; 11: 11-32$ ) but in and of itself it cannot grant family membership.

(3) In Gal 3:26-29, Paul expounds the truth of a salvation appropriated wholly by faith and, in doing this, he seeks to consolidate the church into one family unit:

For ye are all the children of God by faith in Christ Jesus. For as many of you as have been baptized into Christ have put on Christ. There is neither Jew nor Greek, there is neither bond nor free, there is neither male nor female; for ye are all one in Christ Jesus. And if ye be Christ's, then are ye Abraham's seed, and heirs according to the promise.

The Christian, in Christ Jesus, is a child of God by faith-he is one in the Body of Christ, with race, social status, or sexuality offering no advantage with respect to his relation with Christ. On the contrary, as a part of God's family, he is heir to all that belongs to God. Nor is there a strong individualism being taught here, rather there is the transfer from one family to another family or the changing of citizenship--the movement from one line of descent into another. This for Paul means a freedom from servitude, for up until now "God's people" had only lived to serve the law, and they only would live, as far as they could see, by serving the law. With the coming of the Gospel, they were now, Jew and Gentile, to see 
thenselves wholly accepted by God through the merits of Christ appropriated by faith. The children, forming the kinship of God, are members of that family, not because they keep the family rules, but solely because the Father of the family calls them in love. They respond, quickened by His Spirit, and enter within the family circle, through the merits of the death of the elder Brother who paid the ransom price for them. 1

The sinner, reaching out for a salvation outside himself with weak faltering faith strengthened only by the power of the Holy Spirit and accepting God's gift of salvation, also receives the gift of adoption into the family of God, with all the benefits that entails following in its train. ${ }^{2}$

Paul leaves no doubt about the practise of open sin being an eviderce of a lack of saving faith. His strong denurciations in Romans and 1 Corinthians in particular indicates this. The "upward" walk of sanctification is a purification of our lives, but never does he make this cleaning-up process a ground for our acceptance or family membership. ${ }^{3}$ This should caution us against the subtle temptation to allow outward obedience to the family rules to be some sort of ground of our acceptance by the Father. The evidence seems to be that this very tendency has affected the Christian church and in a measure the Adventist church. In particular it is devastating to the

1Matt 20:28; Mark 10:45.

${ }^{2}$ See Scheiermacher, p. 574. Cf. Gal 4:6, 7.

${ }^{3}$ See G. C. Berkouwer, Faith and Sanctification (Grand Rapids: Wm. B. Eerdmans, 1972), pp. 188, 189. 
growth and viability of the smaller church which should be at the "cutting edge" of the growth of the world-wide church. The failure to fully comprehend and accept the fact that our membership in the family is wholly by faith leads to a servitude to the rules of the family for acceptance, with the result that assurance of our salvation is lacking and as a result, joy in what our loving Lord has freely given us is also missing. The outcome is an increasing separation from the sinful, "disobedient" world, and a consequent exclusivism and isolation from souls perishing for want of the gospel hope. The very strength of the small church (its warm, friendly, family-social atmosphere) is sapped when its nembers cannot rejoice in a salvation given freely to them through faith. A large, manycelled church can make some fascade of coping, for it may offer programs and commodoties to its members and the public not possible to the smaller church (and thereby at times possibly promote an ersatz gospel). However, for the small church, such a lack can be shattering--both to the members and to the hope of winning souls from the world.

The family lineage for the Christian is through Sarah, not Hagar; the descent is by way of Isaac not Esau; and citizenship is in the heavenly Jerusalem not Sinai. Does this mean then that Jerusalem is to have nothing to do with Athens? The member of the family of God cannot, must not, remove himself from association with the family of men--for they have no, or little, hope apart from the balm of Gilead dispensed through the church, enfeebled and defective as it may be. By fellowshipping with and serving others, unresponsive as many may be, the church is nourishing itself as it follows 
in the Master's footprints. This double family membership is examined more closely in the next section, but now to summarize: each of the three passages noted above teaches that the ground of acceptance into the family of God is not by race, past family lineage, or any human attribute, it is rather only by faith in the Lord Jesus Christ. The only door into the household of God is therefore the door of adoption--there are no "natural" born nembers, except the elder Brother--the Lord Himself.

Blameless, separated and yet not separated children

In John 17:14-20, the Lord appears to be creating a dilemma, His children are both in the world and yet not of it. As far as describing what "is," He says that they are not "of the world." There is no "maybe" or "perhaps" or a future condition, not even a prayer that they might not be in the world, but rather He is describing what is a fact, for just as. He, the elder Brother, is not of this world, then neither are His brethren and sisters (v. 16). Jesus' prayer to the Father is that they should not be taken out of the world. Does this indicate some sort of concern by the Lord that a real danger could exist for both the world and His people if they withdrew from the world? John makes a play on the preposition "ek" in the Greek, whereby he has Jesus say in verse 15 that he does not pray for God to take them out (ek) of the world, but rather he prays that the Father preserve them from (ek) the evil (or evil one) ("in the world," perhaps). There is a profound difference which unfortunately becomes obscured in Christian practice. To remain in the world and yet to remain untainted and uncorrupted by evil (both in 
the world and from that which could develop from our own sinful nature within--for note "evil" in verse 15 remains unmodified) takes a walk of faith. It is where the battle of Christian maturity is really fought. The world is a dangerous place for children of the Kingdom and weak faith quakes before such a precipitous walk. So human nature tends to withdraw within the safe enclave--the fortress of the Christian community. ${ }^{1}$ No wonder Jesus prayed for the Father to strengthen His children to remain walking and mingling in the world of men, for they are now to carry out Jesus' work of saving souls and uplifting fallen humanity (vss. 18-21). ${ }^{2}$

The church as the family of God is yet still in the world, but its affections, its allegiance, its citizenship is in heaven and so "in Christ" God's child is reckoned as not being "in the world."

Wherefore come out from among them and be ye separate, saith the Lord, and touch not the unclean thing; and I will receive you, And will be a Father unto you, and ye shall be my sgns and daughters, saith the Lord Almighty (2 Cor $6: 17$, 18).

Separated, yet not separated, hearts turned from allegiance

${ }^{1}$ Compare Rahner, p. 30, and Moltmann, Hope for the Church, pp. 132, 133 .

${ }^{2}$ Compare Phil 2:12-15, and also note James Boice's caution against a "self-help" salvation in Philippians: an Expositional Commentary (Grand Rapids: Zondervan Publishing House, 1971), p. 162. Note the idea of "personal initiative" suggested by William Hendriksen, New Testament Commentary: Philippians (Grand Rapids: Baker Book House, 1962), pp. 120-123, and compare Marvin R. Vincent's stress on "man the co-worker with God," Epistles to the Philippians and to Philemon, ICC (Edinburgh: T. \& T. Clark, 1902), p. 65.

3 For a critical discussion of the problem of the authorship of this passage, see.Margaret E. Thra11, "The Problem of 2 Cor 6:147:1 in some Recent Discussion," INTS 24 (1977): 132-148. 
to this world to allegiance to God are then taken by Christ and redirected back into this world. This is a difficult paradox, but this is the way it is and must be if children of the family of God are to remain loyal and develop--the way it must be if a small church is to prosper numerically, spiritually, and in community blessing and influence. The church congregation, and most of all the small congregation in a small community or in an alien district, must $c$ ling to its acceptance by God through faith. It must keep itself unspotted from the corruptions of the community around it, but never must it withdraw from that community. In practice, Adventist churches may be in the community physically, but often the community is unaware of their presence, they have for all practical purposes withdrawn from the world. They have done and are doing the very thing Jesus prayed they would not do. In fact, it was this issue that led Him to plead with His Father to overrule so that they might not withdraw.

Yet communially we do what we do individually or in families. Rather than stay in the alien atmosphere of an unbelieving family and social group, the newly converted Christian usually quickly withdraws from friends and family into the church community. Pressures for this come from both sides, but the usual position of the established church has been to encourage this withdrawal for fear that the new Christian in his immaturity may be easily led astray and out of the church again. There seems to be a similar fear syndrome (sometimes admittedly well-placed) that leads some of our presentations from both pulpit and publications to play down a salvation wholly by faith and elevate, instead, sanctification, obedience, the 
victorious life, etc., out of fear that some will presume on God's grace and mercy and allow moral and church standards to decline in their lives. Both aberrations show a lack of faith in God's saving and keeping power. Surely, both alternatives are dangerous, but the God who has power to call a man from the world, convert him in Christ, change his habits and ways, also has power to keep him from the corruptions of the world. A truly saved man can walk in confidence of God's salvation, believing his salvation, past, present, and future is wholly by faith in what Christ has accomplished for him at the cross.

The pampered, overprotected, doted-upon new Christian (I am definitely not talking of warm personal fellowship and interest), far from maturing in the faith within the safe castle of the church, will ofien in practice develop a legalistic attitude toward his salvation and a growing unconcern toward those outside the church: Faith not lived, stretched, utilized, exercised each day begins to atrophy and die, and a subtle legalism, unrecognized as presumption, creeps in to replace it. The church must not turn aside from the battles of faith which God has purposely ordained that we need for growth in His family.

The Church as a Loving Household

The household of God

Paul could write: "Now therefore ye are no more strangers

ISee Victor C. Pfitzner, Paul and the Agon Motif (Leiden: E. J. Bril1, 1967), pp. 116, 117. Compare Peter T. O'Brien, "The Fellowship Theme in Philippians," The Reformed Theological Review 37 (1978): 9-18. 
and foreigners, but fellow citizens with the saints, and of the household of God" (Eph 2:19). No more are they sojourners, but part of the family of God--the "saints"--the ancient People of God." The picture of the household continues in the next verses to be ilustrated under the figure of the construction of a literal house, with Christ as the cornerstone. The whole church together is a holy temple (v. 21) built up together by the Holy Spirit and founded upon Christ. There is no thought here of the full family members, the citizens, or the saints becoming a holy temple themselves individually at some future eschatological day. Rather as each stranger and foreigner is converted to Christ, he becomes there and then a part of the household of God and a part of the holy temple. ${ }^{2}$

Through the cross we now have direct access to the Father (vss. 16-18) and, as such, enmity is gone and we become a fuil family member in spiritual Israel; not just the member of an earthly state or nation.

The family is a much more intimate brotherhood than the state. The relation to a father is much more sacred and tender than that which we bear to a civil ruler; and therefore, there is an advance in this clause beyond what is said in the former. If in the former we are said to be fellow-citizens with the saints, here we are said to be the children of God; whose character and privileges belong to all those in whom God dwells by his Spirit. ${ }^{3}$

'See J. A. Robinson, St. Paul's Epistle to the Ephesians (London: Macmilian and Co. Ltd., 1903), pp. 66, 67. Cf. "For this is the essential thing in the life of a people; and it is as a people, or a household of God, that Christians have alvays wished to be regarded." Schleiermacher, p. 561.

${ }^{2}$ Compare Charles Hodge, Epistle to the Ephesians (Grand

Rapids: Wm. B. Eerdmans, 1966), pp. 147, 148.

3 Ibid., p. 148 . 
A similar more specialized passage to Eph 2:19 is found in Gal 6:10, where Paul counsels the believers to be alive to serve and help others beginning with "the household of faith." He seems to be saying that the Christian is to do good to everyone wherever possible and surely, he says, most of all for others in the faith.

The "household" illustration used by Paul becomes distorted when we interpret it solely according to our modern nuclear family concept. His use embraces the eastern extended-family lineage motif, whereby all in that large extended family have duties, relationships, authority chains, etc. The household becomes a complete way of life, full of relationships and duties involving others in the large family and revolving around the center--the Father.

The household of love

The first epistle of John is full of the love motif, and in ch. 3:10 he says: "In this the children of God are manifest, and the children of the devil: whosoever doeth not righteousness is not of God, neither he that loveth not his brother" (1 John 3:10). John is revealing the ancient family tradition of the actions of the family member being directly responsible to the family reputation and even, therefore, revealing the true lineage of the individual. There seems no place for a person to be in the family and not maintain the fanily rules--the highest rule of which in the Christian family is that of love. For John, love means obedience to the family rules--righteousness--and without this there is no family connection. It is difficult for us to grasp the supreme place that the NT writers put the matter of loyalty to the Father's rules, for 
all of us have been influenced in various ways by the modern situational ethic. We tritely read of the ancient family emphasis upon blood lineage but forget the equally strong eastern emphasis upon conformity to the family rules.

The NT virtually demolishes the old tradition of earthly blood lineage and replaces it with a family based upon adoption through one Man's blood--that of the elder Brother. In Him we are of one blood, and our earthly blood connections, like the rest of our earthly works, can contribute nothing towards our salvation. Yet once having entered into the family of God, the ancient law of conformity to the family rules remains, yea, is strengthened from the 01d Covenant tradition to now demand even conformity of thought as well as actions to the will of the Father.

John says not to worry if those outside the family hate you (v. 13), for we know, he says, that we have passed from death (the family of men) into life (the family of God) and that this transition will reveal itself in love for the family brethren. So strong for John is this a natural (supernatural?) outworking of family membership that without a love of the brethren it is revealed that that person is still in fact outside the family of God--in the world of death.

John knows of no superficial membership in the Christian church, and opposition to such ideas seems to predominate in the later writers of the NT. Evidently such teachings and practices were creeping (flooding?) into the first century Christian church and maybe, with such similar ideas rampant today, the counsels of these later NT writers take on an added relevance for us. 
John leaves no doubt that salvation is wholly by faith through a profession of belief in Jesus Christ as the Messiah of God (1 John $5: 1$ ), but he immediately links the professor's love for Christ with a love for fellow Christians, and, what is more, a love for the children of God is created in us when we love and obey God (v. 2). It seems therefore that love of the brethren is a supernatural gift bestowed by God, with the Holy Spirit, at conversion. A lack of it, John indicates, is only a revelation that, as yet, individuals are unconverted. These are strong concepts, but I do not know how otherwise to understand John. There is no use working on developing love of the brethren, this comes as a part of true conversion. The unconverted must "work" on submitting his will to God under the power of the Holy Spirit, and see and confess his sinfulness, accept Christ as his Saviour, and thereby be converted.

The problem with a lack of love amongst brethren in the church is largely one of a lack of true conversion--a refusal to admit of a sinful and a lost condition. There is a need to fall upon the mercy of God, to claim the sacrifice of Christ alone for salvation, and to accept this offered gift of life by God's grace, through faith. In other words lack of brotherly love is just a symptom of a problem which is far more serious than we often dare to imagine or admit--a lost condition.

For the small church, such a condition is devastating to every type of relationship and growth. No exhortation to better relationships is likely to have very much effect, for the problem is really a lack of personal acceptance of salvation by faith. Only by believing that God has fully accepted us can we in turn fully 
accept our brethren because we believe God has accepted him as $\mathrm{He}$ has us. It is no wonder that professed Christians, who are unsure of their salvation, have difficulty loving their brethren--for in their thinking no-one is sure just. who God has accepted. Hence the eyes of many are focused on moral improvement as a criterion of acceptance; but it might be asked, at what level of purity and obedience to the rules is acceptance found with God? Instead of sanctification being the outgrowth only of a salvation received by faith, it becomes some sort of salvation process itself. The result is a legalistic present existence and a perfectionistic eschatology plus a non-growth state in the church, for man and his growth become the center of salvation, not what Christ has done for us, accepted by faith. The church as a loving household with doors open wide ready to adopt others drawn by the Holy Spirit seems to be the Lord's desire for his people. And in this role the small church has an immense potential in its natural family-style communion--it can be the community of the children of light. 1 It should present the picture of an open community to the bruised and hurt in the world surrounding it--a place of protection, yet without an air of selfdependence, for it must clearly express in word and deed that it is built upon and sustained only by the living presence of the Saviour. ${ }^{2}$

IAugustus Tholuck, The Gospel of John (Edinburgh: T. and T. Clark, 1860), p. 299. Cf. Karl Barth, C.D., vol 4, part 3, pp. $762-$ 764.

${ }^{2}$ Compare Heb $3: 6$. 
Theological Conclusions

1. The Scriptures seem to view all of God's faithful servants as being in one family (whether in heaven or on earth seems to make little difference). Hence the Word helps provide an antidote to one of the small church's major ailments--a feeling of insignificance, isolation, and inferiority. They are in fact a part of the one great family of God.

2. By being in the family the individual partakes of all the blessings of the family. The small church no less than a large congregation receives the gifts of the Holy Spirit, and because of the small church's unique characteristics it can often be in a better position to recognize, develop, and use these charismatic endowments.

3. The children of the Kingdom are loved as sons and daughters by the Father and they in turn reciprocate. This close family intimacy should be revealed most markedly in the fellowship within the small church.

4. The children act like the Father in that they become peacemakers, forgiving, lifting burdens, healing, and ministering. They no longer live selfish, sinful lives. Now they live to serve and bless others.

5. Believers are children by faith. Just as God, after the cross, negated race as providing a basis of favoritism or advantage toward salvation, so no one can now base his standing before God upon some human label, lineage, or offering. This is particularly relevant for the small church, which characteristically leans heavily upon its past heritage and tends to fight tenaciously to protect its 
traditions and standards. It can be tempted to look upon its battlescarred history of perseverance as some sort of justifying, even saving, merit.

6. The children of God stand as blameless, separated and yet not separated from the world. A solemn warning comes for the small church not to withdraw from the surrounding world, but instead to boldly reach in faith into the worldly community to touch and bless lives.

7. The church is to be a loving household out of which shines the light of God's love through doors open toward the world.

It seems to me that these theological propositions should be a basis upon which any considerations of viability in the smaller church should be formulated.

In the final section a brief examination is made as to how these theological "truths" were incorporated in the actual practice of the churches which developed in the NT era.

\section{A New Testament Practical View}

In this section a brief examination is made of three important areas of church operation to see how they existed in the suggested family-style community of the apostolic church. ${ }^{1}$ It is suggested that the very characteristics of the "family" model of the church are those which were basic to the founding of the Christian church by the Lord and its development by the apostles under the

The cautions of Hans Kung not to slavishly follow the NT model are well taken, and principles only are drawn from NT praxis. See Kung, pp. 23, 24. 
guidance and power of the Holy Spirit. The strengths which are characteristic of the small church seem to have been fully utilized by Jesus and His disciples, and the inherent weaknesses were to a large extent minimized by counteracting actions and circumstances. Hence a powerful potential for church growth and development was actually released into action and the Christian Church exploded.'

Some might argue: "We1l, of course, the church had to start out small and in small groups by necessity, so what? Everything begins that way, but improvement continues with growth, and the smallness, if anything, means a weaker, immature, but necessary condition along the way to maturity and greater power with increasing size." I venture to suggest that such an argument or concept is false, ${ }^{2}$ that, to the contrary, the greater "power" or "potential" lies with the "small," the immature, and that with increasing size comes a corresponding diminishing return on the investment of input energy. It seems evident that this is true whether for an organization, business, corporation, metropolis, club, babies and churches.

In opposition to this objection, it is suggested that by applying all the power potential of "smallness," and I am not negating the supernatural working and power of the Holy Spirit, the apostolic church exploded, but in exploding (e.g., 3,000 converted in a day, etc.) it never became "big"--it remained "small." Yet by

${ }^{1}$ See John A. T. Robinson, On Being the Church in the World (Philadelphia: The Westminster Press, 1960), pp. 83-95. in chapter 2.

${ }^{2}$ Discussion of the "big is beautiful" concept is presented 
"small" I do not mean that viability is equated with "smallness" and non growth, quite the contrary, the small must grow, and at times very fast, but it should remain "small" in its essential characteristics and make-up, which may entail frequent, well-planned, cell divisions. To explain further, let us look at three areas of apostolic church operation: preparation, administration, and worship.

\section{Preparation, Power, and Witness}

Jesus gathered a small group of twelve about Him for close association and instruction. He could have easily expanded the number of His disciples but He seemed to deliberately want to keep it sma11. ' He used an almost ideally sized group for educational purposes (as well as the obvious symbolic significance of the number twelve), and for over three years the group lived virtually as a family. No wonder the churches which the disciples raised up were on a family model. ${ }^{2}$ Even as the disciples grew to seventy, the "sma11 church" idea still remained. When Jesus sent out the twelve and the seventy, some interesting principles of church growth are noted. Firstly, the disciples went out in diads--two by two, presumably for intimate personal relationships with their listeners,

'E.g., for a discussion of the "Messianic Secret" see John Ashton, Why Were the Gospels Written? (Notre Dame, Indiana: Fides Publishers Inc., 1973), p. 64.

${ }^{2}$ John Navone seems to see this family motif particularly in Luke. See Themes of St. Luke (Rome: Gregorian University Press, n.d.), pp. 51-53. 
and for encouragement by one another'--to maximize koinonia or fellowship. Secondly, they went with a powerful message--kerygma, a call to repentance. Thirdly, they ministered to the needs of their listerners--diakonia--healing, casting out demons. There is no indication here that individual disciples just "specialized" in one of the three areas; and even later when the gifts of the Spirit were revealed, the special gift did not negate the threefold aspect of Christian life which should be revealed in every Christian and in every Christian community. Fourthiy, the disciples were to concentrate upon the group with the greatest potential for harvesting at the time, the Israelites themselves, and not the Samaritans or Gentiles. $^{2}$ Fifthly, the disciples were to evangelize, minister, and fellowship in the homes of the people. Close family relationships, with the attempt to win complete households seems to be the motive here. ${ }^{3}$ Finally, the missionaries were to regather to share experiences, counsel from the Teacher, and group nurturing and refreshing.

The group which entered into the Pentacost experience seems to have only been about 120 people (Acts $1: 15$ )--a small church. The whole prevading theme of the first chapter of Acts is unity and

TLuke 9:1-10; 10:1ff; Matt 10:7ff; Mark 6:7ff. Cf., William F. Arndt, The Gospel According to Luke (Saint Louis: Concordia Publishing House, 1956), p. 280.

2 Matt 10:5, 6 .

${ }^{3}$ Notice that even Jesus seemed to need the family warmth and friendship he found in the home of Lazarus, Mary, and Martha (Luke $10: 38-42)$. "Nothing in the account indicates that this was the first visit of Jesus in this hospitable home. . . . The tone of familiarity which Martha employs toward Jesus, makes us think that He had been in contact with this family before.". Arndt, p. 293. 
fellowship. The break in the ranks left by Judas' apostasy and death was repaired, 'the devastating situation of factions in the small church was eliminated, ${ }^{2}$ and they became a united fellowshipping body ready for the Holy Spirit to fall upon them and use them. It was the unity founded in the revelation of the meaning of the Cross and the promise of the continued presence of their resurrected Lord, which prepared that small company for Pentecost.

The speaking in tongues and the sermon of Peter combined small-group instruction with a mass rally-style evangelism--the groups preparing the listeners for Peter's preaching. Although the hearers were evidently dispersion Jews in the main, it does not seem to be restricted only to them. ${ }^{3}$ Hence already at Pentecost there is a strong indication that the newly-born church would have open doors to all nations, all classes, and all people.

Paul deplored the factions in the Corinthian church

The suggestion that the inclusion of Matthias was invalid does not seem to be well supported. See R. R. Rackham, The Acts of the Apostles (Grand Papids: Baker Book House, 1964), pp. 13, 14; and F. F. Bruce, Commentary on the Book of the Acts (Grand Rapids: Wm. B. Eerdmans, 1954), p. 52.

${ }^{2}$ Acts $1: 14 ; 2: 46$. See Charles $w$. Carter, The Acts of the Apostles (Grand Rapids: Zondervan Publishing House, 1959), p. 24. Unity and koinonia does not mean "total conformity," sameness, loss of individuality or of personal ideas or opinions differing from other brethren, no, not at all, but rather a family style "oneness" of social familiarity, love, and inter-action together. Controversy can exist, but only in selfless, family growth together. Compare: Richard B. Gaffin, Jr., Perspectives on Pentecost. (Phillipsburg, New Jersey: Presbyterian and Reformed Publishing Co., 1979), p. 9. Cf. Moltmann, The Church in the Power of the Spirit, pp. 308, 309.

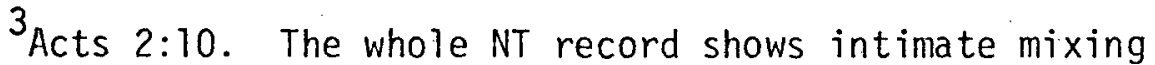
between unbelievers and believers--an absolute necessity for church growth. 
(1 Cor 1:10ff) which, if allowed to develop, would destroy a small congregation and nullify its witness--evidently what was happening in Corinth. He sought to head off the Judaizers in Galatia for a similar reason. ${ }^{1}$ Unity, togetherness in the body of Christ, seems a basic necessity for the church to be the church. It would seem. that the family-style congregations of the apostolic church could not have existed without such "one-ness," and hence Paul also sought to break down racial divisions between Jew and Gentile believers. ${ }^{2}$

The early church witnessed because it had a message to give, it had a kerygma about the Gospel and a call for men and women to repent, accept Jesus as Lord and Saviour, and press into the Kingdom of God. A small church without a message from the Lord is of all institutions the most pitifur and miserable. ${ }^{3}$

The Holy Spirit endowed the church with His power and influence and distributed spiritual gifts as He willed to each member for them to use in furthering the Gospe]. ${ }^{4}$ Not only was the message of the church a story of a divine deliverance from sin and a gift of eternal life, but the very power to propagate this Gospel was also to come from God through the Holy Spirit. The service or ministry

ISchnackenburg, for all his doubts upon the reliability of Luke's record, has no doubts about the incredible unity revealed in the apostolic church. See Rudolf Schnackenburg, The Church in the New Testament (London: Burns and Oates, 1974), pp. 14, 15.

2E.g., His breaking down of the "middle wall of partition" through the Gospe1, Eph 2:13-19; Col 1:20-23; 2:10-17. The unity theme is a strong one in Ephesians (e.g.. ch. 4).

${ }^{3}$ See D. M. Kelley, pp. 35, 58, 82.

${ }^{4}$ Acts 2, Rom 12:3-8; 1 Cor 12; Eph 4:11ff. 
of the apostolic church in healing, casting out devils, etc., was all empowered by God. The fellowship of the early church was under the direct influence of the Holy Spirit ${ }^{1}$ and hence kerygma, diakonia, and koinonia are, in an important sense, charismatic and a direct action of the Divine.

\section{Administration and Structure}

In a sense the establishing of the Christian church was a re-establishing of the theocracy, but now the second Person of the Godhead is present in His church through the Holy Spirit. That is why Gutzke could say: "There is nothing quite like the Christian church. The very structure of its life is different from anything else on earth." 2

The twelve apostles were undoubted leaders of the church, maybe even looking toward Peter as chairman, ${ }^{3}$ but in no sense was there any authoritarian hierarchy with Peter, or any other apostle, at the head. ${ }^{4}$ By the time of the Jerusalem Council, it seems that James had moved into this chairmanship role. ${ }^{5}$ There is considerable controversy today about the actual structure of the apostolic church, ${ }^{6}$ but most agree it was without "ranks and grades." Richard Hanson

1E.g., 2 Cor 13:14. 1966), p. 32 .

${ }^{2}$ M. G. Gutzke, Plain Talk on Acts (Grand Rapids: Zondervan,

${ }^{3}$ See Oscar Cullmann, Peter, Disciple, Apostle, Martyr (New York: The World Publishing Company, 1961), pp. 33-55. Cf. Acts 1: $15 \mathrm{ff} ; 2: 14 \mathrm{ff} ; 3: 4 \mathrm{ff} ; 5: 1 \mathrm{ff} ; 6: 1 \mathrm{ff}$. See Schnackenburg, p. 22.

${ }^{4}$ E.g., Acts $9: 26 \mathrm{ff} ; 11: 1 \mathrm{ff}, 22 \mathrm{ff}$.

${ }^{5}$ Acts $15: 13-33 ; 21: 17 \mathrm{ff} . \quad{ }^{6}$ Schnackenburg, p. 23. 
suggests that ". . . in the early days of Christianity, Christians acted as if the whole church, and not merely the ministers, possessed authority." ]

It seems that a group of elders in Jerusalem held some positions of authority, perhaps as the twelve itinerated to different areas, preaching. The same seems true in Antioch. ${ }^{2}$ The book of Acts indicates that Paul ordained elders in the churches he established, ${ }^{3}$ yet it must be admitted that the churches were largely "democratic" in that each member was accepted, perhaps even expected, to be a minister, not only to take an active part in decisions of the church but also to exercise the three functions of kerygma, diakonia, and koinonia. 4

The apostolic local churches seem to have been mainly house churches with smail congregations. ${ }^{5}$ This does not deny the practice of large, perhaps open air, gatherings or "rallies" such as took

IRichard Hanson, Christian Priesthood Examined (London: Lutterworth Press, 1979), p. 10.

${ }^{2}$ Some question the Pauline authorship of the Pastoral Epistles because of their advocacy of a well-structured leadership in the local church, yet if the record of the book of Acts is at all reliable it reveals that the church structure in the pastorals is only a natural evolutionary development of that already well-revealed from the very beginning of the church. (The silence of Romans to Galatians on leadership by elders and deacons does not prove that they did not exist in the Pauline churches.) (It does not seem as if the apostolic churches were quite as laissez faire as Hanson suggests. Ibid., pp. 12, 13.

$3_{\text {Acts }} 74: 23$.

${ }^{4}$ Eph 4:1-32; 1 Cor $14: 5,15,23-33$.

${ }^{5}$ Acts $2: 46 ; 5: 42 ; 12: 12 \mathrm{ff} ; 16: 13-15,40 ; 17: 1-7 ; 18: 4-8$;

20:7ff. Romans 16. See W. Curry Mavis, Advancing the Smaller Local Church (Winona Lake, Indiana: Light and Life Press, 1957), p. 13. 
place after Pentecost; ${ }^{\prime}$ but the basic church congregation seems to have been smal1, family-style gatherings in house churches. ${ }^{2}$ It was such groups, that caused the later adage, "how these Christians love one-another," to grow. This love was still brimming over into the unbelieving community in the time of Tertullian.

The newly established church formed a community with pooled property and almost a communal type structure. ${ }^{3}$ Although only the Jerusalem church explicitly is indicated as practicing the pooling of financial wealth, the close communal style of church organization seems to have been the norm throughout the apostolic congregations. Such a structure seems a fairly successful way for a new movement to begin, get over its birth-pains, and grow--perhaps, in difficult times, the only way. ${ }^{4}$ The NT churches do not seem to have been true communes; rather the members frequently met together in house churches with many of the positive aspects of a commune in operation, but without the short-lived, negative ones such as the destruction or weakening of the individual nuclear and natural extended families.

'Acts 2:46. Cf. E. Luther Copeland, "Church Growth in Acts," Missiology 4 (1976): 13-25.

${ }^{2}$ See Herbert T. Mayer, Pastoral Care (Atlanta: John Knox Press, 1979), p. 315.

3 Acts $2: 44-47 ; 4: 32-37 ; 5: 1 \mathrm{ff}$. Carter attempts to weaken the "pooled resources" understanding, but is not wholly successful, ibid., p. 40. But compare S. E. Johnson, "The Dead Sea Manual of Discipline and the Jerusalem Church of Acts," in Krister Standahl, ed., The Scrolls and the New Testament (New York: Harper and Bros., 1957), pp. 131-134. See also Schnackenburg, p. 18.

${ }^{4}$ See James T. Richardson, Mary White Stewart, Robert B. Simmonds, Organized Miracles (New Brunswick, New Jersey: Transaction Books, 1979), pp. 7-13. Compare John A. T Robinson, pp. 84-86. 
The method of financial support and the close fellowship seems to portray a type of voluntary "holy socialist" body with real care being shown toward the poor, disinherited, and weak in the community. In comparison most churches today, even very close-knit small ones, seem to be only a weak token copy.

\section{Worship, Fellowship, and Growth}

The Christian evidently continued to worship in the synagogues with their Jewish brethren, even outside of Judea, until the time came when the Jews cast them out. " It may be that "formal" Christian elders and deacons were not elected while Christian communities still worshipped in the Jewish synagogues. When opposition and persecution forced them out, the house churches appointed formal leaders, often evidently under apostolic guidance. ${ }^{2}$ The Jerusalem Christians, at least, still seemed attached to the temple, naturally enough, and probably also with Christian Jews from around the empire, right up until the destruction of the temple in A.D. 70. Most likely the separated Christian congregations worshipped with a liturgy very similar to the synagogue model. Even until the time of Justin Martyr (c. A.D. 150) only small "Christian" refinements had developed. 3 The Pauline espistles indicate that the worship services were lightly and flexibly structured with opportunities for the exercise of

$$
\text { IActs } 9: 20,21 ; 13: 42 \mathrm{ff}: 14: 1 \mathrm{ff} ; 16: 13 \mathrm{ff} ; 17: 1 \mathrm{ff} ; 18: 4 \mathrm{ff}
$$

(e.g., vss. 24-28 the Christians Priscilla and Aquila still worshipping in the synagogue heard Apollos there).

${ }^{2}$ E.g., Acts $14: 22 \mathrm{ff}$.

3 Just in Martyr, "The First Apology of Justin," ANF 1

(Grand Rapids: Wm. B. Eerdmans, 1884): 185:186. 
spiritual gifts, but only with due reverence and decorum worthy of a worship setting. The worship descriptions of praise, thanksgiving, psalms, preaching, prayer, and communion, as found in the NT, all seem to be in the context of a fairly small-sized worshipping community. Local leadership and participation seem to predominate, but there was also great willingness for visiting brethren, particularly apostles, to speak to and worship with the believers. ${ }^{2}$

Fellowship in the apostolic church was of equal importance with kerygma and diakonia, and an integral, indispensible part of both of them. The agape, or fellowship meal, was evidently a common part of the community life, and the fact that at times this meal degenerated in its purpose, because of selfishness, ${ }^{3}$ should be a caution to us that true fellowship involves unselfish sharing and is a fragile thing, ready to crumble if total commitment to Christ and control by the Holy Spirit is not maintained. The house churches of the NT were ideal models for the development and maintenance of fellowship. They were family-style communities, not only loving and nurturing each other but also open to the world outside. Moltmann says of the spreading apostolic church:

It was organized as a voluntary fellowship without regard to the distinctions of religion, race, class, nation, or gender, that divided the ancient world. . . Because of this the church spread quickly and irresistibly; she was the concrete form of freedom and peace. The second historical form Christianity took, therefore, was that of a community open

\footnotetext{
IE.g., 1 Cor 14 .

${ }^{2}$ For example, see Schnackenberg, p. 19.

$3_{1}$ cor $11: 18 \mathrm{ff}$.
} 
to the world, one that offered an independent communal existence in contrast to the traditional lines of division and enmity.

Luke records that the newly born church was of one heart and of one soul. ${ }^{2}$ Such love for one another--actually a reflection of God's love through Christ--could not help but set the church on fire and draw others to the flame.

The early Christian community grew at an amazing speed beginning with the 3,000 added after Pentecost ${ }^{3}$ and increasing daily, ${ }^{4}$ yet it clung to small-house churches. This very factor ${ }^{5}$ undoubtediy contributed greatly to the growth of the church and the characteristic did not change with the spread of the church into the empire. ${ }^{6}$. The small church could survive persecution much more successfully than a large institution ${ }^{7}$ and still keep growing. Perhaps

IMoltmann, Hope for the Church, pp. 38, 39; and Karl Barth, C.D., vol. 4 part 3, pp. 762-764.

${ }^{2}$ Acts $4: 32 . \quad{ }^{3}$ Acts $2: 41 . \quad{ }^{4}$ Acts $2: 47 ; 6: 1,7$, etc.

${ }^{5}$ For whatever reasons, perhaps principaliy from the example set in the synagogues which were usually small. Some have suggested the number of synagogues in Jerusalem just before its destruction in A.D. 70 was about 400 , with probably one synagogue for about every 100 of the adult population (Mavis, p. 12). Although perhaps the disciples sensed or were spiritually enlightened to see that the community dynamics given by Jesus could only be adequately fulfilled in small church congregations.

${ }^{6}$ Thomas M. Lindsay suggests that there were about three to five churches in Rome at about the time Paul wrote his epistle there. See The Church and the Ministry in the Early Centuries (New York: George H. Doran Co., 1902), p. 42.

${ }^{7}$ E.g., Acts $8: 1$. One reason for the survival of Judaism today is its historical clinging to small synagogues (Mavis, pp. 12, 13). Compare this with the collapse of big-institution Christianity in China with the coming of Communist persecution in the 1950 s and 60 s. 
the 70 disciples, increased to 120 (Acts 1), were spread over many house churches in Judea, with house churches dividing and spawning new house communities. Although the significance of meeting in private houses could assist in churches weathering the storm of persecution and promote the feeling of intimacy between members, a small church, meeting in its own church building today, still should be able to maintain many of the positive dynamics of the apostolic small communities.

It seems that not only should we highly regard the example and teachings of Christ and the NT for a solid foundation for the church today but also we should study how the Lord and His disciples actually put that example and instruction into practice in the churches they established. This teaching and practice should have much significance for our church operation today. If the church is not performing according to the NT model, and few would say that it is, then amongst the factors to be examined as to why should be consideration of size, group dynamics, and method of operation. When these are radically different from the NT model then at least the possibility should be considered that the performance of the church will also be radically impaired. It is too simplistic to suggest a one-to-one correlation in every age, such as structural fundamentalism might do. With basic human nature and human dynamics changing little, surely the NT praxis can teach us something in our modern church operation.

The next chapter looks at sociopsychological factors which are relevant to an examination of the smaller church. 


\section{CHAPTER II}

THE CHURCH AS FAMILY--SOCIOPSYCHOLOGICAL VIEWS

\section{Characteristics Peculiar to the Smaller Church}

What is Small?

There does not seem to be any one common definition as to just what constitutes the boundary line of "smallness." Carl Dudley says: "Reduced to a single work, money becomes the most frequent criterion in defining the small church." 1 On this basis James $E$. Lowrey, from the Episcopalian Church, suggests that congregations less than 250 average communicants (or 125 pledging units) are smal1 and therefore forced to operate a "below minimum church program." 2 Some would define small as ". . a church which is struggling to pay its bills;". others would say, ". . . a church that is hard pressed to maintain an organization and committee structure that permits it to participate fully, completely, and in a satisfying way in the life of the denomination and the community. " 3 The "small"

${ }^{1}$ Carl S. Dudley, Making the Small Church Effective, p. 19.

2 James L. Lowrey, Jr., Peers, Tents and Owls (New York: Morehouse-Barlow, 1973), p. 89. Yet as public opinion polls have indicated only one-third to one-half of the members in Protestant churches are found in morning worship services on any given Sunday, hence the Episcopalian "boundary line" may lie above the 500 membership roll names. Cf. W. Curry Mavis, Advancing the Smaller Local Church (Winona Lake, Indiana: Light and Life Press, 1957), p. 10.

${ }^{3}$ Paul 0. Madsen, The Small Church--Valid, Vital, Victorious, (Valley Forge, PA: Judson Press, 1975), p. 16. 
boundary is somewhat arbitrary and denominationally colored, ${ }^{1}$ but most mainline churches place the "small" boundary somewhere near the two hundred/three hundred active membership area. This means that over half of the mainline Protestant churches are classified as smal1. ${ }^{2}$ One definition that is appealing is that which says a church is small when each active member knows every other active member and can and does relate to most reasonably intimately. ${ }^{3}$ One author looking at the "glue" which holds congregations together notes that the "small church glue" runs out at about the two hundred mark:

The congregation with twenty or forty members is small enough that it can be glued together by the two great commandments of Jesus--the love of the Lord and the love of the members for one another. By contrast, however, the congregation with two hundred or more members usually is far too large and much too complex, to function as a "large small group."

Paul Madsen says that many church leaders conciude that any church of less than two hundred is marginal. ${ }^{5}$ He then says that introversion takes place in the struggle for survival, with little

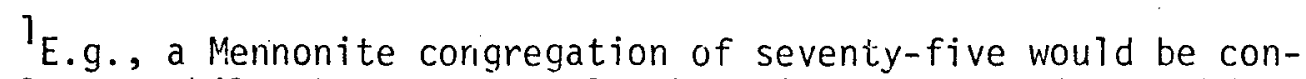
sidered large, while the same size Presbyterian congregation would be quite "small" and very marginal in viability; cf. Dudley, Making the Sma11 Church Effective, p. 20.

${ }^{2}$ See appendix $A$.

${ }^{3}$ Cf. Carl S. Dudley, "Membership Growth: The Impossible Necessity," Christian Ministry 8 (July 1977): 9; cf. also idem, Making the Small Church Effective, pp. 32-35.

${ }^{4}$ Lyle E. Schaller. Assimilating New Members (Nashville: Abingdon Press 1978), p. 23.

${ }^{5}$ Madsen, p. 10. The fact that this number would place twothirds of Protestant churches and over 80 percent of Adventist churches in the "marginal" category may indicate that our basis of judgment of both what constitutes "church" and "marginality" may need revision. 
energy, finance, etc., left over for the necessary outward movement of the church to meet its Gospel commission. If this is a true picture it is perhaps an unfortunate one. Admittedly there is financial tension below this two hundred membership level, but the equating of this with an introverted church is postulating what I think is a false root cause of inaction by small churches--at least in terms of how the evidence seems to be pointing in the Seventh-day Adventist church, some of which is examined later in this chapter.

The Seventh-day Adventist "rule of thumb" seems to call a church "small" when it drops below the one hundred membership mark-but this is an arbitrary line that seems not well founded. Lyle Schaller recommends that Protestant churches averaging fewer than forty-five members a Sunday should be classified as "small." He suggests that the "ideal size" for a one pastor congregation is about 175 average Sunday attendance. 1

Schaller probably comes closest to the Adventist perspective when considering size, although his ideas are primarily based upon financial and program conditions, whereas I would prefer to define a congregation as "small" when it operates fairly well as a single cell or principle group with each member reasonably familiar with every other member (i.e., following Dudley). In other words a church is "small" when it operates as an extended family--in real actual practice, not in the usual Christian cliche sense of "we are all one

ILyle E. Schaller, "Twenty Questions for Self-Evaluation in the Small and Middle Sized Church," Church Management 8 (April 1977): 18. Cf. Dudley, Making the Small Church Effective, p. 20. 
big family in this church." ${ }^{\prime}$. If this is said literally of the operation of a church above the 200 to 250 membership level then it is almost a technical impossibility for it to function as a single unit.

Therefore I will not attempt to suggest an upper limit to the size of the small church beyond that suggested above. This study therefore, is concerned with churches which operate in the singleunit family style. The cohesive "glue" and the conformity to a family operation becomes stronger as the congregational size diminishes--at least in a healthy, small church; although as the church gets smaller a tension grows between this characteristic and the pressure to be God's church in the community.

\section{Interpersonal Relationships}

As already suggested, the small church is really distinguished by interpersonal relationships which are different from the condition existing in a "large" church.

The small congregation is the appropriate size for only one purpose: the members can know one another personally. Not all the members can know all the others on a continuing, face-to-face basis, but they can all know about one another. They expect to be able to "place" everyone physically and socially in the fabric of the congregation. The caring cell church may be defined as a primary group in which the members expect to know, or know about, all other members. ${ }^{2}$

Each member can usually associate faces and names, family connections, and, often, the place in the church where each person sits. The over-whelming characteristic of the small church is personal

TSee Clyde H. Reid, "Small Groups Are Here to Stay," Union Seminary Quarterly Review 8 (May 1963): 395, 396.

${ }^{2}$ Dudley, Making the Small Church Effective, p. 35. 
relationships. It is one of the reasons for the tenacity of the small church to hang on to life; a disfunctioning of this relationship is one of the most common reasons for a small church to die-whether physically or spiritually. A bitter feud in a small church is a devastating situation because the group is primary and any infighting can be primitive and vicious.

The small church often has little else to offer except personal relationships. Its programs are spartan, its performance unpolished, its singing at times a capella by necessity, its Madison Avenue image near zero. Yet this one characteristic of warm family. relationship seems to give the small church a potential to meet some of the most basic needs in every normal human being. It can more than make up for its other lacks if this relationship is recognized, nourished, and deveioped in a genuine warm Christian spirit.

\section{Operational Methods}

In operation, the small church performs differently from a large church; invariably its staff is "non-professional" and, in some groups, so is the minister. In an age of increasing professionalism in the church, the small congregation seems to be an increasing incongruity. As Dudley says: "It does not fit the organizational model for management efficiency." 1 The probiem is compounded by the development since the early 1800s of success in the ministry being equated with the size of the church being pastored, a situation which

TIbid., p. 24. 
does not seem to have been at all prevalent prior to about $1800 .^{1}$

The financial improvement in pastors' salaries which usually accompany a move upwards in church size is not practiced in the Seventhday Adventist Church due to the function of the Conference organization through which appointments are made and the centralized tithing system which is a base for paying salaries.

But the system has not eliminated the equating of church size to pastoral professional success. ${ }^{2}$ This system of central dispersal of ministers, while viewed with suspicion by more congregationally minded Christians, does mean that appropriation of ministers tends to follow more of a field or church conference need rather than that of a sufficient number of local pledging or tithing units. ${ }^{3}$ I think the overall financing situation tends to give the very small churches better pastoral leadership than they might otherwise be able to afford if purely congregational financing were practiced. Hence it probably helps perpetuate the small church. On the other hand the conference system also tends to discourage churches from

'See Robert W. Lynn and James W. Fraser, "Images of the Small Church in American History," in Jackson W. Carroll, ed., Small Churches Are Beautiful (San Fransicso: Harper and Row Publishers, 1977), pp. 1-18. Lyle E. Schaller notes the importance of the "smali" congregation's self-esteem to its goals, expectations, and performance. "Looking at the Small Church," Christian Ministry 8 (July 1977): 6, 7 .

2 Personally, I think the Seventh-day Adventist financial arrangement is helpful and more in line with the NT emphasis upon equality in all things amongst the believers.

3 The practice is closely linked to the philosophy of the Adventist church which in general places the Gospel commission to all the world above the needs of individual Christians or even individual churches. It does help to minimize one form of inequality and deprivation, but opens up other dangers and problems. 
growing too big because most Conference administrators, operating under the Adventist Gospel Commission philosophy which places evangelism to all the world in top priority, are fairly reluctant to multiply ministers or other paid officers in the one church.

The Adventist church in practice tends to follow other Protestant groups in having shorter pastorates in small churches. A reverse practice might do less harm, for a small church, operating and living by personal relationships, often does not have the time to embrace pastors and their families into this close-knit group, hence his leadership and planning does not become assimilated into their midst.

Peter Wagner calls the primary-cell group a "kinship circle" because it is so close to a family situation. ${ }^{2}$ Its operation is also more of an informal family one, yet on the other hand, each member, as in a family, has his place "around the table." If one is missing, the group is aware of it and each is interested in the situation or condition of the absent member.

\section{Meeting Needs within the Small Church}

\section{Limited Plant and Programs}

Because of financial and leadership limitations, the small

${ }^{1}$ On the other hand the Adventist philosophy does not always encourage the establishment of new churches because the Conference administration realizes it becomes financially responsible to provide ministerial leadership whereas the individual new congregation would be virtually solely responsible in a more congregational type organization.

${ }^{2}$ C. Peter Wagner, Your Church Can Grow (Glendale: Regal, 1976), chapter seven. 
church often has to run a minimal or sub-minimal program by largechurch standards. The problem arises when we begin to set program standards far beyond the limited guidelines in the NT which seemed to have developed only very little by the time of Justin Martyr (c. A.D. 150). What is worse is that the standards are often those of a "full program" large church, and the small church operates under a constant inferiority complex because it can never match up. Perhaps a general shift in values needs to be made before administrators and smal1-church members can be educated into fully accepting themselves and their own programs--tailored to their need and potential. I believe that pastoral education is needed to improve worship services but it must be along Scriptural principles of worship and not along large-church worship practices. As Hollis Green says: "It is clearly evident that a church whose program suits the actual needs of its congregation has the basic framework for adequacy. ${ }^{1}$

Within the limitation of plant and staff and adequate church program can be operated right on down to a small company, provided "adequate" is defined relatively with respect to that size group in that situation and the peculiar needs of the people in that congregation. ${ }^{2}$ What is more, the program should also be capable of meeting the Lord's gospel commission and the expectations of the denomination providing they are "adequate" for the small church. 3

I Holl is L. Green, Why Churches Die (Minneapol is, Minn.: Bethany Fellowship, 1972), p. 36 .

${ }^{2}$ Other needs are discussed later in this chapter.

3 The denominational expectations are examined in the next chapter, and future modifications may need to be made to assist the small church to be and to be seen as viable. 


\section{7}

\section{Individual Personal Needs}

Long-time members

The small church is often heavily dependent upon its heritage, "a cocoon in which significant experiences can be remembered and replayed." 1 Each long-time member has his or her place in the pew--usually where he or she has sat for many years. The small church fairly successfully provides this cocoon for memories and fellowship in which brothers and sisters are often much "closer" in reality than blood relatives. Hence it meets the needs of the older long-time members with their typical late-and post-middle-age needs. Perhaps it is this characteristic which contributes most of all toward the tenacity of the small church to hold onto life.

The problem is that small churches can be so satisfied with just this need fulfillment that they forget the other need fulfillments which accompany the gospel commission imperative. (Hence the needs of three other groups yet to be considered are often badly neglected.) Here probably lies the source for lack of growth in many small churches. In fact, any numerical growth with new members joining becomes a threat for it disrupts the existing "family" and changes the "choreography of worship." 2 Subconsciously, if not consciously, many small churches just do not want to grow. Some may say, "Well, why can't they just go on meeting their own limited

'Dudley, Making the Small Church Effective, p. 42.

${ }^{2}$ On this interesting characteristic in the small church, called by Dudley "The Choreography of Worship," see Making the Smal1 Church Effective, pp. 35-37. Cf. also Membership Growth, p. 10. 
need-fulfillments, they aren't doing any harm and at least the church remains open in that place?" The problem is that it is a prescription for death, a long, lingering, cancerous-style demise of a tenacious small church. Death is certain unless a change comes, for a church cannot exist for. long when its reproductive facilities are put out of action. Before a physical death comes, some sort of spiritual death has already taken place because over a long period of time a totally introverted church finds it difficult to even maintain enough members by "natural increase" to stave off ultimate death. Thankfully, it seems the majority of small churches are not in quite this terminal condition, but unless the other need fulfillments as examined here are being met, their viability must be less than adequate.

Potential new members

A major principle in church growth is that a church wishing to grow must provide, and be seen by the community surrounding it as providing services, fulfillments, beliefs, relationships, etc., which individuals or groups in that society need. It is in this area that the smal1 church by current nature and tradition is at a weak point. It was not true, in general, in the apostolic church, for that institution, with its small churches, was meeting the hunger and needs of the first century, and it grew. Yet the available evidence indicates that its individual congregations remained household "small" churches. The question is, "Did the small church model of the apostolic era contribute toward the rapid growth of the early church or was it just a natural characteristic of a new grass-roots organization?" 
I hope the previous chapter has at least indicated the strong possibility that small size, family-style churches can be most effective in church growth and viability. This chapter seeks to ask, "What sociopsychological forces latent in a close-knit group can contribute toward this favorable trait in small churches? How can it be recognized, and mobilized to meet the needs of potential new members?"

Madsen lists three basic assets present in the small church:

1. Warmth and intimacy of fellowship, which a large church has to work to achieve but which is more natural to a small church

2. The possibility of identifying mission and concentrating upon it

3 The ability to be more flexible in approach, to minimize structure, and to reach agreement more easily. 1

If the small church can recognize these assets and see that it can meet the needs of a large number of people yet unreached with the gospel, then the first step can be taken in formulating mission goals to build up the congregation. But the foundation must be laid upon the Gospel commission which sees every person a candidate for entry to the Kingdom of God. Exclusivism and introversion are two of the chief enemies of the small church. The people most open to being drawn into a small-church circle are often the ones least desired by over-scrupulous or fearful members in the church, ${ }^{2}$ yet

Madsen, p. 29. Cf. Jurgen Moltmann, Hope for the Church, pp. 24, 25; also Dietrich Bonhoeffer, Life Together, p. 38 . ATso note that religious movements have very often sprung up amongst the poor rather than the middle and upper classes, for example, the Christadelphians. See Bryan R. Wilson, Sects and Society (Berkeley: University of/California Press, 1961), p. 317.

2 I remember one small church where on the day I preached the most notorious prostitude in town attended worship. After the 
the situation and seed-bed for growth in the small church which beckons these very "outcasts" seems to be the same as in NT times.

The potential in the small church to meet the needs of an increasing section of the population is very great, because the three areas of strength meet the very needs of a large part of the population, particularly the below thirty age group. The insecurity growing in our modern age, caused by the shattering of families, is throwing young people into adulthood desperately searching for some loving, warm, family-style community. The characteristics of a healthy, small church can meet these needs in a way few other organizations can match.

It was just such factors which drew thousands of young people into the new communal-style sects which grew up out of the Jesus Movement at the end of the 1960s. For example:

Another important "mobilization" consideration is the communal life-style adopted by most branches of the Jesus movement, which quite often was dealing with persons who, for various reasons, were not able to stay at home with their families. . . An obvious solution to the problem of a lack of community among these young people was a communally oriented movement. . . . This natural growth of communal living for people who would otherwise be homeless furnished a surrogate family for many of the participants

service the leading elder felt it his duty to tell her she would be welcome to attend the church but only if she truly had reformed her ways and straightened up her life. I think that lady was looking, probably desperately, for some acceptance as a person, for a warm fellowship of forgiveness, for the Gospel, for salvation, perhaps without being able to spell it out that way. Instead she got the law and a decided impression that she really wasn't welcome. She didn't return. 
and a loving, caring atmosphere in which to live. The importance of the communal motif in changing people's views and behaviour and in maintaining the new perspective should be obvious.?

The above study of the Christ Communal Organization reveals that the searching youth had "written-off" the large mainline congregations as being part of the condemning "establishment," often looking upon them as the strongest of the forces they were opposing. Probably much of the criticism was poorly founded, but the small church did and still does stand in a more favorable position to provide a warm, caring "surrogate" family for the many young adults in search of this need. ${ }^{2}$ The strong doctrinal and moral standards of the Seventh-day Adventist church are really not a barrier, if anything they are a positive attribute for growth, ${ }^{3}$ for the most successful of the new Jesus Movement sects have very high moral and doctrinal standards, close to those maintained by Seventh-day Adventists. 4

Usually outsiders can successfully enter the small church only by adoption. This takes mutual experience, faith, and

1 James T. Richardson, Mary White Stewart, Robert B. Simmonds, Organized Miracles (New Brunswick, New Jersey: Transaction Books, 1979), p. XXV. Cf. Moltmann, Hope for the Church, pp. 44, 45; also The Open Church, p. 110; Spirit, p. 330.

${ }^{2}$ Three small churches in Australia provided this family atmosphere to hippy groups and saw many of these young people become converted to Christ and join in church membership. Cf., Jack Balswick, "The Jesus People Movement: A Generational Interpretation," Journal of Social Issues 30 (1974): 23-42.

${ }^{3}$ See D. M. Kelley, Why Conservative Churches Are Growing (New York: Harper and Row, 1972), pp. 56-59; 125-129.

${ }^{4}$ See Richardson, pp. 19-21. 
understanding, but the strong potential koinonia of the small church makes the small-church group a highly effective adoptive family. "Adoption depends on mutual respect and understanding. It cannot be rushed. It cannot be earned. Adopted members are often around the congregation for a long time before they 'become members. "1

\section{New baptized members}

Koinonia seems the weakest element in the application of the church-growth trilogy (the denominational kerygma and diakonia being reasonably strong) for many small Adventist churches, and it is a fatal weakness. The small church has a natural advantage in fostering koinonia (fellowship), but it must be developed and exercised or the introversion disease can afflict the body, and true centrifugal koinonia will die. Oosterwal's study in the Lake Union Conference seems to indicate that koinonia is the most important of the three in bringing people into the Adventist Church, for 67 percent of those joining the church from a non-SDA background first became acquainted with the SDA message through neighbors, friends, relatives, and acquaintances. In fact, relatives and acquaintances were the most important influence on persons to become members of the church (57. percent). 2

Fellowship and relationships between people is such a strong factor in both bringing people into the church (evangelism) and keeping them there (nurturing) that any weakness in koinonia is

IDudley, Membership Growth, p. 11.

${ }^{2}$ Gottfried 0osterwal, Patterns of S.D.A. Church Growth in North America (Berrien Springs, Michigan: Andrews University Press, 1976), p. 40. 
fatal--particularly for the small church which really has koinonia

as its foundation. Oosterwal can say:

It appears from a number of data that the church membership among Seventh-day Adventists is strongly a family affair. In some of the churches nearly every member had some primary or secondary relatives who were also members.

The encouraging thing in these statistics is to see natural family relationships being maintained within the church and the potential within the families to lead still others to the Lord Jesus Christ. The danger, though, is that the congregation will forget that the commission of Christ demands that the church provide a warm "surrogate" family to the homeless and lost out in the world. From just relating to each other, the smal1-church members must open their arms to others so that searching, needy souls can also be adopted into the family of God. When "natural descent" obscures the open arms and doors to "adoption," gospel koinonia becomes lost and the small church begins to look only inward and starts to wither.

The 1971 study by Wicker and Mehler on the assimilation of new members in a large and a small church indicated that a smaller United Methodist Church (338 members) was significantly more effective in assimilating new members than a larger church 1599 members). Wicker was testing the theory of Barker $(1960,1968)^{2}$ in which it is claimed that,". . . the behaviors and experiences of members of

\section{IIbid., p. 34. But note the real danger for introversion} to arise.

2R. G. Barker, "Ecology and Motivation" (Nebraska Symposium on Motivation, 1960) 8, pp. 1-50; and R. G. Barker, Ecological Psychology: Concepts and Methods for Studying the Environment of Human Behaviour (Standford: Standford University Press, 1968). 
voluntary organizations are influenced by the degree to which an organization's activities are undermanned." 1 The evidence seemed to support Barker's theory, but a later (1972) study by Wicker, in the area of participation, made of 320 churches ranging from less than 100 members up to 3200 members did not show support for Barker's undermanning theory. ${ }^{2}$

Oosterwal's study seems to indicate that ". . . churches between 100 and 350 members in general, showed the largest growth numerically, as well as in many of the other dimensions of church growth. "3 Schaller suggests that a church with an attendance level of about 175 was about ideal for one pastor. 4 If the postulated "optimum" size of an Adventist church lies in the small church area of 150-350 members and that the "one family glue" begins to become unstuck above this ievel, then some questions may be raised as to the validity of Wicker's (1972) study. Wicker says the results are similar to those found in large and small schools (Barker \& Gump, 1964) and large and smal1 industries (Parker \& Lawler, 1965; Willems,

IAllan W. Wicker and Anne Mehler, "Assimilation of New Members in a Large and a Smal1 Church," Journal of Applied Psychology 55 (1971): $151-156$.

${ }^{2}$ Allan W. Wicker, Joseph E. McGrath, and George E. Armstrong, "Organization Size and Behaviour Setting Capacity as Determinants of Member Participation," Behavioral Science 17 (1972): 499-513. Various tentative suggestions were made to explain the results, e.g., small churches may not really be undermanned as was assumed, physical plant size may be as determinative as numerical size for attendance. The concept of just what "undermanning" means may need to be reexamined.

3 oosterwal, p. 28.

${ }^{4}$ Schaller, Twenty Questions, p. 18. 
1964b) in which small units have lower absentism and turnover rates, higher productivity and higher job satisfaction than large units.' The evidence seems to be strong that in both potential and practice, small churches are better capable than large churches of assimilating and nurturing new members. Hence small churches should be aware of this trait and recognize in it a positive characteristic in their "small church personality."

"Internal growth" members

The evidence seems to indicate that in the previous three groups, the small church seems to have some advantages in meeting each group's characteristic need, but in holding its own baptised young people, the small church seems to be at a disadvantage. Dudley comments: "Unfortunately, the young people who have been 'born into' the small church often leave the community when they become young adults. Some will return; many will not. ${ }^{2}$

The Seventh-day Adventist Church has become increasingly dependent upon its church-school system to help provide a strengthening environment of Christian education for its young people. That seems to be a contributing factor in Oosterwal placing his optimum size for an Adventist church in the upper limit of the "small church" spectrum--i.e., at about 200-350 members. He says:

'Alan W. Wicker, "Size of Church Membership and Members' Support of Church Behavior Settings, "Journal of Personality and Social Psychology 13 (1969): 286.

${ }^{2}$ Dudley, Membership Growth, p. 11. Cf. the weakness of an overpowering type conversion in "staying power; "Dietrich Bonhoeffer, Life Together (New York: Harper and Brothers, 1954), p. 33. 
. . churches of 200-350 members have by far the best potential for church growth. . . . Religious commitment is strongest and according to some social scientists, even indissolubly bound to small communities. Because of the strong emphasis in the S.D.A. Church on the education of its children, it seems that the optimal size for an Adventist community ranges between 200 and 350 members. That church is usually strong enough to operate its own church school (Grades 1-8). It has enough talents to rely on for its programs and activities, while it is still small enough to foster the face-toface relationship so necessary for real communion and fellowship.

But what of the small church at the other end of the spectrum--in the under-fifty membership group? The numerous boarding academies in this country provide some place for small churches to send their high-school-age young people, but many, having had a non-church K-8 education, are often not happy or prepared to break their peer group bonds and attend a strange academy, of ten hundreds of miles away. In any case, these young people are lost to the sma11 church even if not to the denominational church. It must be admitted that in providing for the needs of school-age young people, the very small church is at its weakest. That very age group needs some group of peers with which to mix, learn, share, and grow up, and in many very small churches there may be less than six or seven in the school-attending age group. If one spouse (usually mother) remains home and is suitably interested and inclined, she can teach the child the basic rudiments of nature, reading, and writing, etc., until the age of seven or eight, ${ }^{2}$ but from this age,

10osterwal, p. 31.

${ }^{2}$ See Raymond S. Moore, Better Late than Early (New York: Readers Digest Press, 1975), and School Can Wait (Provo, Utah: Brigham Young University Press, 1979). 
social interaction with peers would seem to be needed and school entry would not want to be further delayed. The problem may be postponed but not solved by this infrequently practiced partial remedy. According to my experience, the basic minimum church membership for a spartan one-teacher church schooi seems to be about 150. Sometimes smaller groups can consolidate to operate not only a church school, but other social, youth, mission, and community activities, even if this means the very small individual church becomes in reality a unit that meets alone on Sabbath morning as a "Sabbath morning worship fellowship." 7 Few small churches choose this action, possibly because they have not looked honestly and objectively at their situation and formulated what they can and cannot do.

Some small, isolated Adventist churches have no other Adventist churches near enough to consolidate for certain activities. If the theological position of the NT, which pictures the church as both called out of the world and also sent into the world, was accepted and applied, it could lead to some radical actions by the small church. The first chapter looks at this important teaching and considers the dangers which the sallying forth of active faith can bring, but the church militant is ever in a "dangerous" position and must remain so. if carrying out the Lord's commission. Closer social ties could be made with other evangelical groups in the area which share similar standards as do Adventists on drinking, smoking, and

IKeith L. Inskeep, "Finding One's Own Success Model," Christian Ministry 8 (July 1977): 23. 
entertainment, etc. ${ }^{1}$ Social gatherings, prayer groups, and possibly even a church school could be supported jointly, ${ }^{2}$ if a loving Christian spirit were maintained by each party involved. ${ }^{3}$ If the Adventist message is really believed, faithfully lived, and tactfully and lovingly witnessed to before other Christians in close association, it cannot fail to make a strong impression upon others. The small Adventist church in such a situation should grow as its members testify to a salvation received by faith and lived out in the life.

\section{Age, Social, and Interest Groups Within the Small Chruch}

Most students of church growth list homogeneous groups as a general basic requirement for growth. It may be so, but this should not encourage a kind of exciusivism, for this would seem to be counter-productive to growth and against Christian principles. There seems no doubt, however, that not only do small groups which are open to the community, such as the house churches of the NT,

This close interaction seemed to be characteristic of both the apostolic church and also the early Adventist community.

${ }^{2}$ While pastoring a small church, two of my children attended a Lutheran elementary school for two and one-half years. We found it much more satisfactory than the one year they spent in a public school. The opportunity for both parents and children to dialogue on beliefs was considerably greater than if the children were attending the public school. Cf., Charles Mylander, Secrets for Growing Churches (New York: Harper and Row Publishers, 1979), p. 136.

3 Even if the fear that young people could form relationships and eventually marry out of the church should be realized in a few cases, the situation for the young people in many smiall churches could hardly be worse than at present and the interaction arrangement may prove to be a great deal better. 
lend themselves to growth, they also tend towards homogeneity. But Christian principles surely forbid the withdrawal of warm koinonia from everyone willing to attend and join a church. Hence small churches have the difficult task of identifying with similar homogeneous groups in the worldly community for maximum mission effectiveness, as suggested in church-arowth theory, while at the same time providing an open door to anyone who might wish to join and then assimilating into the family all who wish to become members--only a true spirit of koinonia seems to be capable of such performance.

Yet there is really no such thing as true homogeneity in a congregation even in a small church where the racial backgrounds are similar. Within a small congregation there are different age and interest groups, different social and financial groups. A large church normally accepts this condition as is and, in fact, these various subgroups usually form the structures of the cells which are the real operating units of the big church. The big church lives with its cliques and its interest and generation gaps for it can do little about them, yet the one-family unit of the small church cannot happily live with divisions. ${ }^{2}$ To be healthy the small church must make some reasonable joint effort to meet the needs of the

${ }^{1}$ See Mylander, pp. 133-138, and cf., Schaller, Assimilating New Members, pp. 65, 66, and C. Peter Vagner, Our Kind of People (Richmond: John Knox Press, 1978).

${ }^{2}$ For the differences in relationships within a society and a community, note John Macmurray, Persons in Relation (New York: Harper and Brothers, 1961), p. 157. Cf. also Bonhoeffer's caution between human and spiritual love in human relations (Life Together, p. 34). 
various age and interest groups because, as Macmurray says:

A community, however, is a unity of persons as persons. It cannot be defined in functional terms, by relation to a common purpose. It is not organic in structure, and cannot be constituted or maintained by organization, but only by the motives which sustain the personal relations of its members. It is constituted and maintained by a mutual affection. This can only mean that each member of the group is in positive personal relation to each of the others taken severally. The structure of a community is the nexus or network of the active relations, of friendship between all possible pairs of its members.

Accomplishment of tasks and purposes are not the primary concern of the small church, maintaining and fostering personal relations between communicants is, and any attempt to increase the viability of the small church must major in this area because it operates together as a group, cell or family. Therefore not only does the small church involve a larger percentage of its members in leadership, in operating positions in the church, and in the worship activities, but it involves a larger proportion of its members in all activity in the church--as compared to a big congregation.

In a large church, if a hike is organized by the Young People's Society, usually the young people alone will go; but not so in small churches (the smaller the church the more the "not so"). If the youth organize a hike, everyone is virtually under obligation to go. At a hay-ride, in a healthy small church, grandparents and babes in arms will all be there, together with the youth who probably organized it. The age groups at the function will naturally tend to congregate together, but the interaction between groups is frequent

TMacmurray, pp. 157, 158. Cf.. Dietrich Bonhoeffer, The Communion of Saints (New York: Harper and Row Pub., 1963), pp. $\overline{81,82 .}$ 
and there is no doubt that it is a combined group activity. They mutually put investment together into the group and fellowship envelopes all within the community.

As the family of the small church inter-relates it cannot help but have an effect upon the individuals and the individual nuclear families of which it is comprised. Although the situation can create problems, it would seem that from the standpoint of family life it would have a therapeutic value, creating not only a better relational life between members, but a better climate within the individual nuclear families.

Small churches can meet the needs of the various age and interest groups within them but they can usually do it successfully only by involving all (or nearly al1) the members, for what they do, they do as a family. It means that sixty-year olds who never dream of playing games at a large church social will "gird up their loins" and get in there with the young people in a small-church event. A Sunday baseball game engaging a smal1-church group will not be between two teenage teams, as it might be in a large-church event, but between two teams of ages from seven to seventy (or more). This does something to the human dynamics of the people involved, and I cannot help but feel that its overall result is beneficial for individual, family, and church health.

In a Management by Objectives program for the small church, mission-goal planning must major in the area of personal relations; and plans must take into account an operation which must cater to the group as a whole. Within this one-cell concept, the individual spiritual gifts must be seen to find their input into the united 
Body, or the program probably will not succeed.

If the commission of the Lord that the church is also the church for the world is forgotten, and the gaze is directed inwards with the doors shut to "them" outside, the introversion plague, characteristic of small groups, will be realized. Reginald Smart sees this terminal sickness as the malaise of contemporary Protestant churches, He, too, sees true koinonia being best expressed in small groups, and, in calling for a restoration of such groups, he points out the accompanying danger of introversion:

Some form of the small-group remedy is certainly necessary if the churches are to recover the unique koinonia without which they are very questionably the body of Christ. Moreover, it cannot be denied that such groups can provide a solution to some of the problems of relevance and appropriate adaptation of the church to the world. But such groups can also be stumbling blocks if they are exclusive. They also tend towards introversion: they can easily become ends in themselves rather than mearis to mission, and thus become the very antithesis of that participation in the world which is the most basic expression of love for one's neighbour.?

It would seem that the introversion inherent in the modern psychological approach which places self-actualization at the top of the pyramid of an individual's psychological development does not meet either biblical directives or those for lasting good mental health. Hence just seeking to meet the individual's apparent needs or interests is not enough--even from a secular psychological viewpoint. According to Viktor. Frankl:

TReginald K. Smart, "The Local Protestant Church as an Instrument of Mission" (Th.D. thesis, Boston University School of Theology, 1964), p. 248. On pp. 25]-253 Dr. Smart gives limitations of the small group which are worth noting. 
... pleasure is primarily and normally not an aim but an effect, let me say a side effect, of the achievement of a task. In other words, pleasure establishes itself automatically as soon as one has fulfilled a meaning or realized a value . . . the more we strive for happiness, the less we attain it. Peace of mind also must content itself with being an automatic effect, for it is self-destroying as an intention. . . A good conscience is one of those things which can be brought about only as an unintended side-effect, and is destroyed at the moment that it is sought after directly... true morality. . . begins only when man has begun to act for the sake of something or someone, but not for his own sake, that is, for the sake of having a good conscience or of getting rid of a bad one.

Just attempting to meet age, social, and interest-group needs within the small congregation will not meet either individual real needs or the need of the church to be the church in the unbelieving community. The small church must be a community with open doors to the world, attuned to the needs "out there" and using its gifts and talents to help meet those needs, not just distantly using diakonia as a "softener" or "wedge" so that the kerygma can be promoted. Rather, genuine koinonia should flow out of the church carrying diakonia and kerygma with it, but it should precede and carry the other two in its train.

Therefore meeting human needs in the "other," both within and without the church, is an absolute necessity for the healthy small congregation--and even perhaps, if Frankl is correct, for the health of the individual member.

It is the contention of the author that an adequate view of man can only be properly formulated when it goes beyond homeostasis; beyond self-actualization--even beyond man himself!--to that transcendent sphere of human existence

TViktor E. Frankl, "Beyond Self-Actualization and Self Expression," Journal of Existential Psychiatry 1 (1960): 8-9 
in which man chooses what he will do and what he will be in the midst of an objective world of meanings and values.

It would seem therefore that both healthy individuals and churches must depend on healthy relationships among people. Fellowship or koinonia is therefore the lifeblood of the small church and to a large extent its viability depends upon the primary presence of this characteristic.

\section{The Family Function Model for Need Fulfillments}

If personal relationships are the forte of the small church, then it seems legitimate to suggest that the one-cell operation of the small congregation shares much in common with the one-cell operation of a nuclear or extended family. Therefore there should be some relevence in the study of family dynamics which is applicable to the smal1 church.

John Rodgers in his study of family functions noted the considerable variation that existed amongst theorists on the number of functions performed in a family. ${ }^{2}$ For a working model of family functions he chose the Reichert (1978) Model of Eight Universal Family Functions which is really a synthesis of various functions suggested by many authors from 1940 to 1976. As Rodger's research supported this model fairly well, I would like to use it in a modified

${ }^{1}$ Ibid., p. 17. For a philosophical view, note John Macmurray, The Self as Agent (London: Faber and Faber Ltd., 1957), pp. 127-145.

${ }^{2}$ John E. Rodgers, "Assessing the Social-Psychological Interior of the Family: An Empirical Basis for the Study of Family Functions" (Ed.D. dissertation, Berrien Springs, Michigan: Andrews University, 1979), pp. 20-31. 
85

form in application to the small church as a family. 1 Reichert's functions are incorporated under three broad categories: (1) maintenance, (2) developmental, and (3) maintenance/developmental. I modify, where I feel it is applicable, the elements existing within each function.

I. Maintenance Functions

A. The Reproductive Function, which involves

1. Replacement of members

2. Application of the Great Commission Imperative

B. The Economic Function, which involves

1. Efficient achievement of material needs

2. Division of labor according to abilities and gifts

C. The Protective Function, which involves

1. Spiritual, psychological, and physical protection of members

a. Development of a system of rules

b. Enforcement of rules

2. Social Control

II. Developmental Functions

A. The Nurturant Function (leads to emotional becoming), which involves

1. Emotional gratification

2. Tension management

3. Therapy

B. The Philosophical Function (leads to moral becoming),

IIbid., pp. 28-31. 
which involves

1. Values

2. Ethnics

3. Morals

c. The Socialization Function (leads to social becoming), which involves

Rights and responsibilities regarding interactions with others

D. The Education Function (leads to cognitive becoming), which involves

1. Acquisition of knowledge of Sacred History

2. Conditioned aspects of personality

III. Maintenance/Development Function

The Personalization Function (leads to idiosyricratic becoming), which involves

1. Body structure

a. Differing personalities

b. Differing ages, interests, and concerns

c. Differing social and financial strata

2. Body function

a. Differing calling and concerns

b. Differing spiritual gifts

c. Differing commitments ${ }^{1}$

I I have not modified the essence of these eight functions but I have taken the application to the nuclear family and applied it to the situation of a voluntary community drawn together as a worshiping group. Each function now relates to the individuals in the small church and how this primary group meets the personal needs expressed in each function. 
A brief interpretation of each function as I feel it applies to a family-style small church is as follows:

IA. Reproductive function: the need for the church to grow in numbers to replace members and to carry out the imperative of the Great Commission (Matt 28:19, 20), which commands the bringing into the family of others from outside.

IB. Economic function: keeping the church economically viable so that needs of plant, equipment, education, mission, etc., will be met, and using the available labor to help accomplish this.

IC. Protective function: protecting members from heresy; schism, and apostasy by using a wise system of rules and their enforcement-which acts also as a social policeman.

IIA. Nurturant function: meeting the emotional needs of the members with a system of tension and conflict management in a therapeutic climate, e.g., showing love and affection to one another, visitation, Sunshine bands, counselling, marriage and family enrichment, etc.

IIB. Philosophical function: developing spiritual, ethical, and moral values, not only in theory, but in practice in relationships with family members and those outside the family. IIC. Socialization function: assimilating rights and responsibilties toward others in the group by interaction with them, e.g., independence maintained but within the approval and acceptance of the community. 
IID. Educational function: growth in knowledge of Scripture, sacred and church history, etc., plus a certain conditioning of personality to the group mold.

III. Personalization function: acceptance of people who are different and hence a different application of traits, with a respect for individual personality within the family.

It would seem that the eight functions of a nuclear family, as suggested by Reichert, are also relevant and applicable to the family-style operation of the small church.

\section{Examination of Growth and Viability Potential in the Small Church}

Church-Growth Criteria and Studies

McGavran, like Smart and many others, sees introversion as a major stumbling block in church-growth--churches in this condition really see no possibilities for growth and believe that such might cost something that they are unwilling to pay. ${ }^{1}$ Therefore in order to be viable the small church must be open to the worldly community outside. It must have a deep burden for unsaved souls, hence its kerygma is to be of the highest meaning. Salvation must be seen as lying only in acceptance of the Lord Jesus as Saviour, but if reconciliation is not experienced between the members, then fellowship will be absent and hence the church has no desire, power, or effectiveness in contacting the unbelievers outside its door.

The small church by nature is strongly attached to its past, but if that past does not go back far enough--to the cross--for its:

IDonald A. McGavran and Win C. Arn, How to Grow a Church (Glendale: G/L Publications, 1973), p. 5. 
foundation, then some other aberration of heritage could usurp the place of the one Cornerstone. This to me seems vital if a living fellowship, the life-blood of the small church, is to be present in abundance.

We live from the past, but we do not live in it. We live in the present. So also with the Christian fellowship. While its persisting memory makes it plain that it lives from its past--centrally, from the event which is called by the name of Jesus Christ and of which he is the abiding point-of-reference--it must necessarily live in the present. And in that present, it lives by its relationship with the contemporary world. It is open to that world and to the influences which the world brings to bear upon it, even when it appears to reject both the world and its influences. Conversely, it affects the world, although sometimes it seems difficult to indicate any plainly visible evidence of this affect. But this relationship is the double one of acceptance and rejection.'

The small church must not only have a driving imperative from the Lord to evangelize the world outside its door, it must aiso see the possibilities there and set goals to accomplish them. The small church, even with its spiritual gifts, may see little potential in the group for reaching its goals, but in its strategies it should give full recognition to the tremendous mission-potential the small church has in its natural characteristic of koinonia. Halverson's counsel is ever so applicable to the small congregation:

It is plain, therefore, that no congregation or community of faith can be what it ought to be until it takes fellowship seriousiy--until it continues steadfastly in fellowship as well as the apostle's doctrine, breaking of bread and prayer. . . In the Sermon on the Mount, our Lord made it clear that fellowship was fundamental to life. The unity of brother with brother, believer with believer, disciple with disciple was primary and should be given priority in

${ }^{1}$ Norman Pittenger, The Christian Church as Social Process

(London: Epworth Press, 1971), p. 78. 
the life of a church. In other words, anything that destroys or disrupts or minimizes fellowship should be treated as intolerable in the life of the community.

Robert Rhoads found the following factors, amongst others, to be important for growing churches: strong pastoral leadership and preaching, high laity involvement and satisfaction, openness to new ideas, leadership involved in recruiting, training and involving new members in the church life, congregation satisfaction with worship services, location in new, growing area, homogeneity of the community with the congregation. ${ }^{2}$ They match up well with those of McGavran and Arn, namely planning for growth, setting growth goals, conducting more efficient meetings, committing more members to discipleship, having small-group fellowship, utilizing direct evangelism, and multiple ministries to meet people's needs. ${ }^{3}$ A small church may not be able to very easily change its location or its racial make-up, but even these should be considered in its future planning. It is evident that in educating the small church for growth and viability the role of an enlightened pastor/leader is vital. ${ }^{4}$ He can educate the congregation into seeing its potential and its abiltiy to set its own goals. He therefore can have a powerful influence upon the koinonia present in the small church. The growth factors

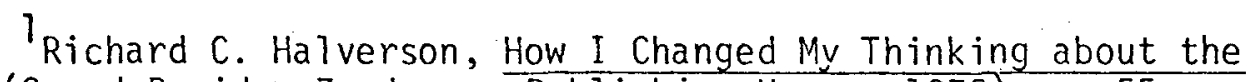
Church (Grand Rapids: Zondervan Publishing House, 1972), p. 55.

${ }^{2}$ Robert I. Rhoads, Sr., "Church Growth and Decline: A Case Study of the Variable Factors Effecting Membership Ingression and Egression of Four Churches" (D.Min. thesis, Lancaster Theological Seminary, 1979), pp. 16, 17.

3 Ibid., p. 18.

${ }^{4}$ Cf. Donald J. MacNair, The Growing Local Church (Grand Rapids: Baker Book House, 1975), pp. 39-43 
of McGavran and Arn are all possible for the small church and some fit better into its mold than for a large church. McGavran recognizes the potential of the small or house church in describing such in Puerto Rico:

Visitors become part of a small church, small enough so real friendship can be developed, real care can be exercised, and real koinonia can be experienced. Real responsibility is delegated to laymen. 1

MacNair suggests four fundamental resources upon which every viable local church must be developed: (1) the headship of Christ, (2) the final authority of the Bible for all our faith and our practice, (3) the work of the Holy Spirit, and (4) the eldership providing spiritual oversight.

Upon these resources MacNair builds four functions needed in every viable local church: (1) worship, including, of course, the sacraments; (2) growth in grace, including instruction, sanctification (and therefore discipline), and fellowship; (3) outreach, including evangelism, missions, and community involvement; and (4) acts of mercy, including the diaconate and community and world concerns. ${ }^{2}$

Therefore it would seem that these four resource questions should be asked of a small church looking at its viability, or of a group thinking of starting a new church. Do they see the implications in these expected resources and is each of them present in their midst? Then the group should face penetrating questions as to

\section{IMcGavran, p. 96. Compare "Small Assemblies of Christians} Are a Very Important Part of. Church Growth," p. 90.

${ }^{2}$ NacNair, pp. 21-25. 
how these resources can be applied in the four functions. Are they, or can they, provide adequately these functions, and can they set realistic goals which will develop each of these four areas? If not, then the viability of an existing small church should be questioned, and for a group thinking of beginning a church, it may be better to wait and recruit more strength before launching out.

Mayer suggests a five-point program to monitor the spiritual health and vitality of a Christian community. He calls for a balanced and continual growth in five Christian actions or graces: worship, fellowship, witness, service, and nurture. 1

The list does not differ essentially from that of NacNair, and in a way both are really an expansion of the three basic elements of Christian life: kerygma, diakonia, and koinonia (preaching, service, and fellowship).

It would seem that the three basic functions of Christian life (perhaps five for Mayer) can be expressed best in the familystyle, one-cell community of the smal1 church, particularly if the "lost" one in modern big-church Christianity, that of koinonia (or fellowship), is to have its rightful place in the NT trilogy model. Note Mayer's observation:

Again historical research suggests that this fivefold growth happens best, and perhaps only, in closely knit communities where the nembers feel some sort of compulsion to help each other and to lean on each other. In the history of the church, especially, but not only, in the first five centuries, a pattern repeats itself with regularity, and many Christians have experienced this in their own communities. As the congregation grows, fellowship decreases, and when this happens,

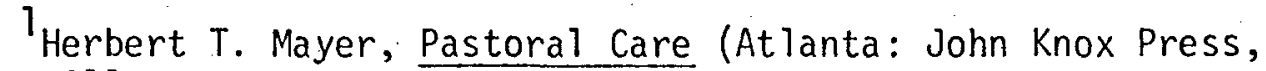
1979), p. 311. 
the total vitality of the congregation decreases. The percentage of people involved in worship falls off. The practice of service declines as individuals begin to distance themselves from other members. . . Members stopped caring for each other. 1

Far from modern church-growth movements by-passing the small church, it would seem that lasting, healthy growth in Christianity, as McGavran has expressed it, is intimately tied to the growth and viability of the small, family-style congregation.

\section{Recent Seventh-day Adventist Studies}

One of the most significant studies on church growth yet done in Seventh-day Adventist churches was that conducted by Gottfried 0osterwal in the Lake Union Conference (consisting of churches in the states of Michigan, Indiana, Illinois, and Wisconsin). ${ }^{2}$ One of the findings in this study was the great diversity of the constituency, and paralleling this fact was the great diversity of programs in the churches. Oosterwal believed this diversity of both people and programs to be a strong factor in growth, although where growth was absent it was often because the programs of the church had no appeal to the believers and therefore failed to stimulate growth. $^{3}$ He felt that:

One of the consequences of the findings may well be that the church will stimulate local congregations to become more creative in developing programs that appeal to a much larger number of believers and that are much more geared towards particular local needs, resources and challenges. 4

IIbid., pp. 312, 313.

${ }^{2}$ oosterwal, Patterns of SDA Church Growth in America--A study of various size churches in the Lake Union of Seventh-day Adventists. ${ }^{3}$ Ibid., pp. 63, 64. 4Ibid., p. 65. 
Another finding was the seemingly utter dependence of Adventist church growth upon the minister (pastor) and the way he fulfills his role. Perhaps this is due to paternalism which has grown to an unhealthy extent. If so, then the role of the pastor needs to be re-examined. Oosterwal makes two suggestions: (1) to see the pastor as called primarily to preach the Word of God, which in turn stimulates the believers to missionary zeal; and (2) to see the pastor as a preparer of the laity for evangelism, service, and church growth.

Another finding was the overwhelming influence of the laity in church growth and this through the simple experience of testifying to what Christ had done for them in their everyday life and work and social contacts. Oosterwal suggests three ways to develop this poteritial: (1) to seek ways to stimulate believers for spontaneous witnessing, (2) under guidance from the pastor, to develop spiritual gifts within the congregation, and (3) to help the laity apply and coordinate their gifts for church growth. 1

In making recommendations Dosterwal calls for a "humanizing," direct-contact, person-to-person emphasis in mission, and this can only be by an inner motivation "bubbling out" of the joyful believer. He calls for a personalizing of approach which places the plans and goals in the local church itself instead of denominational uniformity. In relation to church size, 0osterwal's study showed that churches between 100-350 members had the largest growth, percentage wise, with large churches (over 600) having the smallest. The

IIbid., pp. 66-73. 
100-350-member size also had the highest religious commitment and involvement in evangelistic outreach. They also had the lowest apostasy rate and the greatest commitment to tithing and stewardship programs. He summarizes by saying:

From these various data on the size of the church the conclusion may be drawn that there is indeed a casual relationship between church growth and the size of the church. . . These findings also concur with anthropological and sociological studies on the small community. Religious commitment is strongest and according to some social scientists, even indissolubly bound to small communities.

Perhaps the dynamics operating in small churches has yet to be fully grasped by Adventists, although it seems to have been recognized by an Adventist pioneer and writer, Ellen G. White. ${ }^{2}$ Oosterwal seems to be approaching the heart of the problem when he connects church growth with koinonia:

Adventist churches may have to rediscover that the success in church growth is as much dependent upon the creation of genuine communities of believers characterized by a warm fellowship as it is on the preaching of the message. For, as this study on church growth has shown over and over again, proclamation wi thout fellowship remains mere sterile propaganda that lacks the power to win souls to Christ. This challenges the church to discover what structures can

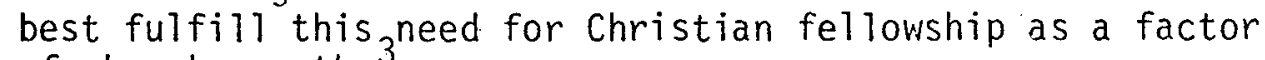
of church growth.

Mike Scofield conducted a project in 1975, whereby he looked at the relationship between church size and offering performance. ${ }^{4}$ The survey covered approximately three hundred churches of various sizes in central and northern California and in Oregon.

${ }^{1}$ Ibid., pp. $30,31$.

${ }^{2}$ See Comprehensive Index to the Writings of Ellen G. White (Mountain View, California: Pacific Press Publishing Association, 1962), 1:557, 563 .

${ }^{3}$ Oosterwa1, p. 53. ${ }^{4}$ Ibid., pp. 83-87. 
The results indicated no real relationship between tithe and church size. In churches over one hundred membership it did appear that local offerings tended to decrease, per member per year, with the increasing size of the congregation.'

In mission offerings, per member per year, there was quite a strong trend for decrease as church membership size increased. Similarly, there was a definite trend for the ratio of Sabbath School offerings to tithe to decrease as church size increased.

Scofield's research would seem to indicate better average mission offerings, per member per year, in small churches when compared with larger institutions. There was also a better average giving for local church offerings in smaller churches (at least down to one hundred members), and the same trend seems to be true of the ratio of Sabbath School offerings to the tithe.

The reasons for these results are not clear. It does not appear that the suggestion which says that the increasing financial efficiency of larger organizations results in a decreasing proportional giving by the members is a valid one. This could explain local church offering trends, but hardly explains the even stronger trend to reduction in mission giving. An explanation related to Barker's "undernlanning" theory may be more valid, i.e., that the higher percentage of members in leadership and participative positions in the smaller churches produces a stronger interest and drive

In central California this trend was continued down to churches less than 100 membership also, al though churches in the 300-500 membership size were anomolous to the trend. Ibid., p. 86. 
to be involved in the church's overall program. ${ }^{1}$ If this suggestion should prove to be valid it could provide support for the concept that sma11 churches are more "natural practicers" of M.B.0. than larger institutions. 2 Possibly small churches are just more conservative than larger churches and hence still remain more closely supportive of the traditional top-priority of mission offerings of the Adventist church. Scofield's study has provoked a number of questions which shourd be investigated further.

Although there may not have been as spectacular results from the introduction of M.B.O. in small churches as when compared with large organizations, nevertheless positive improvements in church operation and growth seem to have resulted from two projects implemented in smal1 churches. One was conducted in 1976-1977 by Eoin Giller in a small forty-member congregation and the other by 01 iver Johnston in a 150-member church. ${ }^{3}$ Both projects were based on the application of Management by Objectives principles, and Giller's in particular indicated that the goal setting and implementation increased the level of koinonia in the church (which tends to be

I It may need to be determined whether this tendency for increasing involvement embraces everyone in the small church or just those actually involved in leadership and active participative positions. In very small churches this may well nigh be everyone!

${ }^{2}$ At the same time it could indicate that the introduction of M.B.O. programs into the small church may make a much smaller impact (and hence result in disappointment) than in a large church. See chapter III.

${ }^{3}$ Eoin E. Giller, "Building up the Body of Christ: A Study in Church Revitalization Leading to Church Growth" (D.Min. project, Berrien Springs: Andrews University Seminary, 1977); 01 iver L. Johnston, "The Introduction of Management by Objectives into the Buchanan, Michigan Seventh-day Adventist Church" (D.Min. project, Berrien Springs: Andrews University Seminary, 1979). 
"naturally" high anyway in a healthy small church). As a process to move small churches off their common plateau situation, the above studies seem to indicate encouraging success with M.B.0.

A current (1980) church-growth study in progress looks at 320 randomly selected Seventh-day Adventist churches in North America. Of these, 37 percent are below 50 members, 62 percent are below 100 members, and 82 percent are below 200 members. 1 It indicates that the Seventh-day Adventist Church is primarily a sma11church denomination--at least in North America. From the initial results, it seems that there is no real relation between size of church and "Kingdom growth" (defined as baptisms and professions of faith for a given year, minus members removed from the roles through apostasy, death, and those who are missing, although, in total, the very small churches (below fifty members) had the highest percentage of churches with zero "Kingdom growth" (56.1 percent and their actual percentage of growth (4.4 percent), where it occured, was also below average. ${ }^{2}$ Since this study embraces black, white, and Spanish churches, it is interesting to see how the ethnic differences effect church size variations. From discussions with church pastors and from personal observation, it seems that black churches may have inbuilt processes, programs, or ethnic characteristics which seem to enable many of their larger churches--within the Adventist

\section{${ }^{1}$ See North American Church Growth Study (Berrien Springs:} Andrews University Seminary, 1980), table 1.

${ }^{2}$ Large churches (over 500) had the highest percentage of some "Kingdom growth" (90 percent), but to deduce from this that churches of this size therefore are the denomination's best prospects for growth, would be very unwise. See tables 2 and 3. 
denomination at least--to maintain an elevated level of koinonia resulting in a high fellowship and "celebration" climate in the

\section{TABLE I}

CHURCH SIZE

\begin{tabular}{cc}
\hline \multicolumn{1}{c}{ Size } & Percent \\
\hline $1-50$ & $37 \%$ \\
$51-100$ & $25 \%$ \\
$101-200$ & $20 \%$ \\
$201-300$ & $13 \%$ \\
$501-750$ & $3 \%$ \\
$751-1000$ & $1 \%$ \\
$1000+$ & $1 \%$ \\
\hline
\end{tabular}

Note: The random selection of $300+$ churches in the North American Division Church Growth Study yields the above break-down which should represent the Division church sizes by percentages.

TABLE 2

CHURCH SIZE AND GROWTH

\begin{tabular}{rccc}
\hline $\begin{array}{c}\text { Size of } \\
\text { Church }\end{array}$ & $\begin{array}{c}\text { Average } \\
\text { of Growth }\end{array}$ & $\begin{array}{c}\% \text { of Churches } \\
\text { with } \begin{array}{c}\text { Growth } \\
\text { or Decline }\end{array}\end{array}$ & $\begin{array}{c}\% \text { of Churches } \\
\text { with Some } \\
\text { Growth }\end{array}$ \\
\hline $1-50$ & 10.6 & 66.7 & 33.3 \\
$51-100$ & 6.4 & 36.7 & 63.3 \\
$101-150$ & 6.8 & 26.7 & 73.9 \\
$151-200$ & 1.6 & 35.7 & 64.3 \\
$201-300$ & 3.9 & 17.6 & 82.4 \\
$301-400$ & 2.7 & 40.0 & 60.0 \\
$401-500$ & 3.0 & 33.3 & 66.7 \\
$501-$ & 2.4 & 27.3 & 72.7 \\
\hline \multirow{2}{*}{ Average } & 6.7 & 42.0 & 58.0 \\
\hline
\end{tabular}


TABLE 3

KINGDOM GROWTH

\begin{tabular}{rccc}
\hline $\begin{array}{l}\text { Size of } \\
\text { Church }\end{array}$ & $\begin{array}{l}\text { Average } \% \\
\text { of Kingdom } \\
\text { Growth* }\end{array}$ & $\begin{array}{c}\% \text { of Churches } \\
\text { with O King- } \\
\text { dom Growth }\end{array}$ & $\begin{array}{c}\% \text { of Churches } \\
\text { with some King- } \\
\text { dom Growth }\end{array}$ \\
\hline $\begin{array}{r}1-50 \\
51-100\end{array}$ & 4.4 & 56.1 & 43.8 \\
$101-150$ & 6.6 & 35.0 & 65.0 \\
$151-200$ & 6.2 & 17.4 & 82.6 \\
$201-300$ & 5.5 & 14.3 & 85.7 \\
$301-400$ & 3.7 & 17.6 & 82.4 \\
$401-500$ & 2.8 & 20.0 & 80.0 \\
$501-$ & 3.8 & 33.3 & 66.7 \\
\hline Average & 5.4 & 9.1 & 90.0 \\
\hline
\end{tabular}

Source Note: These details as per Mid-Project report of the North American Division Church Growth Study (1980).

Note: *Kingdom growth is calculated by subtracting, for any given year, church apostasies and missing members from church baptisms and professions of faith (i.e., it ignores transfers of membership).

church, a level which seems to be rare in large white churches.' Hence as this paper has looked primarily at small white churches in comparison with larger white churches, a similar study amongst black churches may need to take other factors into account.

A program implemented by Caleb Rosado is in operation in the All Nations Adventist Church in Berrien Springs. This program, conducted in a group in the upper limit of the small-church category (a membership of 264), does have implications for the small

1 But compare with C. Peter Wagner, Your Church Can Grow (Glendale: G/L Publications, 1976), pp. 97-103, and Edward A. Rauff, Why People Join the Church (New York: The Pilgrim Press. 1979), pp. 86-96. 
church in that church goals, planning, and operation are conducted solely by the whole church at monthly business meetings rather than by a church board--which does not exist in this church. ${ }^{1}$ Subcommittees are responsible to the business meeting only, and strong pastoral nurture and visitation by lay-leadership is an important part of this church's operation. This church is making a real attempt to employ a spirit of koinonia in its operating structure and is using some "natural" characteristics of small churches to help accomplish this.

\section{Summary}

1. Small churches are probably best classified as congregations where every attending member knows and can relate fairly intimately with every other attending member.

2. Sma11 churches are characterized by their emphasis upon personal relationships rather than task or goal orientation, hence they are communities rather than societies.

3. Churches classified as small have difficulty meeting the different age, social, and interest-group needs within them. The most difficult need to meet seem to be those of the teens and young married. This may be because so many members in small Adventist churches are in the fifty year-old-and-above group. This weakness can be partially offset by efficient use of what programs are provided, because all or nearly all the church participates in them.

'See suggestions made in chapter III on small churches preferring to make decisions as a family (i.e., at business meetings) rather than in a select group such as a board. 
The needs of high-school age children are particularly difficult to meet in the very small church, and radical programs may need to be implemented to help solve the problem.

4. Small churches have a tremendous potential for growth and viability in their "natural" possession of warm, family fellowship, because many people in the world are searching for membership in just such a "surrogate" family.

5. The functions present in a nuclear or extended family seem also applicable to the family of the small church: Reproductive, Economic, Protective, Nurturant, Philosophical, Socialization, Education, and Personalization. The viability of a small church can be gauged to a large extent by seeing how it matches up in meeting these functions in its congregational life.

6. Church-growth studies both within and outside the Adventist Church see church or group size as a highly relevant factor in growth. Although the relation of size to growth is not altogether understood there seems to be some indication that positive factors present in family-style groups are important ingredients for growth of the Christian church. The characteristics of primary or single-cell groups seem to be a necessity for the development of koinonia or fellowship--a much-wanted commodity in churches today.

7. Finally, it could be said that there is every indication from the socio-psychological makeup of family-style groups that the small church will continue to be in the majority, not only in the Adventist Church, but also in the rest of the Protestant world, and that if its positive factors are recognized and utilized, it could 
103

be the fastest growing class of congregation as the Church enters the final two decades of this century. 


\section{CHAPTER III}

\section{THE CHURCH AS FAMILY--IN RELATION TO CURRENT}

SEVENTH-DAY ADVENTIST STRUCTURES

In this chapter I wish to look at the structures as set up by the Church Manual and their relevance. to the characteristics present in the small church. The principle aim is to note how these structures help, hinder, or remain neutral toward assisting viability or growth in a small church.

In briefly looking at the organizational development in the church it would seem that from the very early days church leaders have struggled with the tension between freedom, spontaneity, innovation, and congregationalism on the one hand, and unity, structure, world-view, and representative-presbyterianism on the other. Both positions have strengths and weaknesses. which greatly effect small churches and their operation.

The Seventh-day Adventist church began in a way, not unlike the apostolic church, with individual conversions, but usually involving the nuclear family and often extended family accessions. It began with house churches and generally amongst the poorer classes with membership widely scattered. 1 Ellen White indicated in 1893

?From Ellen G. White's address to the General Conference in 1893: "From the first our work was aggressive. Our numbers were few, and mostly from the poorer class. Our views were almost unknown to the world. We had no houses of worship, but few publications, and 
that organization in the early days was needed:

To provide for the support of the ministry, for carrying the work in new fields, for protecting both the churches and the ministry from unworthy members, for holding church property, for the publication of the truth through the press, and for many other objects, organization was indispensable.

Within ten years from this statement by Ellen white the church had reorganized into departments and unions, particularly to carry out a world-wide work in the various areas she mentioned. But another important reason for her call for reorganization was to dissassemble the oligarchical structure which she disapprovingly called "kingly power." 2

Now that a strong organizational structure for which Ellen White fought, and I believe rightly so, has been established, the Church must closely guard against the weaknesses inherent in such a structure from sapping the iife power of the church and suffocating the strength and vitality that lies with the individual local congregation. The organizational structure can contribute toward the vitality and free individuality for growth of the local church but it can only do so by closely monitoring and at times restraining its own latent power, continually looking at its role from the individual

very limited facilities for carrying forward our work. The sheep were scattered in the highways and byways, in cities, in towns, in forests." C. C. Crisler, Organization (Washington, D.C.: Review and Herald Publishing Association, 1938), p. 12.

Ibid. She adds: "Yet there was strong feeling against it among our people." Cf. J. N. Loughborough, The Great Second Advent Movement (Washington, D.C.: Review and Herald Publishing Association, 1909), pp. 343-348.

${ }^{2}$ See Ellen G. White, Testimonies for the Church (Mountain View, California: Pacific Press Publishing Association, 1948), 8:232, 233, 236, 237. 
congregation's point of view and not down upon the congregation from the apex of a political pyramid.

There are strong movements taking place in Christianity toward re-establishing initiative and authority down at the "grassroots" level in the local church, and Seventh-day Adventists should closely follow and learn appropriate lessons from this development. The Adventist Church has much to be thankful for in the positive contribution a strong organization has made, but that does not make the organization and the Church immune to its inherent weaknesses. The small local church seems to suffer most with increasing distance between congregation and major leadership decision making. ${ }^{1}$ Perhaps because it feels it has little "clout," a small church makes little effort, and rarely does it resort to cooperative approaches together with other small churches because such moves in a hierarchical structure are often viewed as rebellious.

I would like to look first of all at the denominational structures for the preparation of candidates for church membership from the point of view of a small-church situation. The Church Manual is my main source, ${ }^{2}$ although other references are used as well when these are helpful.

${ }^{1}$ See Hollis L. Green, Why Churches Die, pp. 145-150.

${ }^{2}$ Seventh-day Adventist Church Manual (Washington, D.C.: General Conference of Seventh-day Adventists, 1976). I am using the 1976 edition, realizing that as this paper is being written, revisions for a new edition are already being made following the 1980 General Conference Session. 


\section{Family Member Preparation}

\section{Accession into the Family}

It is only natural that a manual, by its very nature, be terse and legal in its tone, hence some understanding needs to be made in the application from rule-book to flesh and blood people. Yet the undoubted emphasis and intention in the manual is upon people being correctly instructed, believing the right things, and then, through the correct procedures, becoming church members. 1 The candidate is requested to acknowledge belief in and/or practice the twenty-seven listed doctrines. There are solemn warnings given against ministers who baptize inadequately instructed candidates and of candidates who do not fully understand their position. Experience tells me of the battles many people have who come out of the world to meet these high requiremerts, and I do not believe any requirements should be lowered in any way. ${ }^{2}$ Yet the presentation in the manual seems to be little different from the requirements for joining a lodge or a club, admittedly one with high standards. There seems little in the Manual expressing the fact that the candidate, whether one from "natural increase," from another Christian body, or from the "world" is about to participate in the most momentous, joyous, and beautiful thing in this life--joining the family of God.

This aspect should really be the one most emphasized and it becomes even more relevant and powerful in a small church. In joining a big

\section{${ }^{1}$ Church Manual, pp: $50-63$.}

${ }^{2}$ It is encouraging to see though that in the new revision (1980) a real attempt being made to express the Fundamental Beliefs in a more positive tone. 
church, the new member appears small and insignificant. If he settles into church fellowship it will almost inevitably be with a cell group within the large congregation. There is an increasing attempt to make these cells warm, family fellowships with those of like interests, but it seems difficult to move these cells beyond goal-oriented motivation and to cultivate the type of one-family fellowship of a small one-cell church.

An attempt is made in the Manual to place membership on a spiritual basis by emphasizing conversion, "but it seems more a conversion of accepting points of doctrine rather than one involving a personal belief in the all-sufficient sacrifice of Jesus upon the cross for our salvation--an acceptance of Him as Saviour and Lord with the doctrinal beliefs and life-style changes clearly growing out of that salvation by faith.

Hence the Manual majors on the vow of the candidate and his grasping of doctrinal points, whereas a family model would place the weight of exhortation upon the existing family members, their lifestyle example, and their responsibility of love, fellowship, and nurture of this newly born addition to the family. A rather sad paragraph in this section of the Manual is found on page 63 where guidance is given in the case of "Receiving members who are not known." Evidently it is particularly addressed to converts of an evangelist and it suggests that the church pastor or elder visit the

${ }^{\mathrm{l}}$ Church Manual, p. 50. 
baptismal class and become acquainted with the new prospects for membership, suggesting that this will "enable the church to be better prepared to receive the new members into church fellowship." It is depressing to contemplate just how often this actually takes place in practice and how sadly inadequate a method it is to assimilate new converts into membership.

From the first contact with an interested person, koinonia should be as strongly implemented and practiced as kerygma, together with diakonia. It would seem that any evangelistic "crusade," whether conducted by a "professional" evangelist or by a local pastor-laymen program, which does not spend as much in planning time, and money on the koinonia aspect of a total ministry as it does on the kerygma is doomed to failure or mediocre results. ${ }^{1}$ If people were just brought into church membership by evidence, reason, and mind alone, the almost total kerygma emphasis might be justified, but the fact is that they are not. ${ }^{2}$ Human beings are also

ISome evangelistic "preaching" could not be classified as kerygma (even under the broader use of this term within this paper) and perhaps this departure from the $N T$ is at least a partial reason for evangelistic failure.

${ }^{2}$ It would seem that Adventists still are not over the influence of the Enlightenment in their own church. By this I mean the belief that mind and reason are the deciding and controlling factors in man's actions, i.e., reason above all else controls man's destiny. "Kant saw the Enlightenment as man's claim to be recognized as an adult, responsible being." Peter Gay, Issues in Western Civilization, 2 vols., ed. Leon Apt (Boston: Holbrook Press Inc., 1974), 2:2. Together with the deification of reason went a teaching of man's ultimate perfectibility in this life and a denial of man as being inherently sinful (p. 1). Cf. Crane Brinton, Ideas and Men (New York: Prentice Ha11, Inc., 1950), p. 369; al so idem, European Intellectual History (New York: Macmillan Co.. 1964), pp. 1, 13; and Robert E. D. Clark, Science and Christianity (Mountain View, California: Pacific Press Publishing Association, 1972), pp. 35-39. 
heart-led creatures, they not only want fellowship, they have to have it to live. The small church by nature has an abundant latent supply of warm, family fellowship which needs to be extended beyond the open front doors into the surrounding community. If converts cannot immediately bring their own unconvinced family and friends into the church with them, then the church family must become the family of the new converts. ${ }^{1}$ The congregation must become family to the new converts long before they enter the baptismal font if koinonia is to be a strengthening, healing balm through the traumatic period of doctrinal and life-style changes. Then the congregation must remain with the newly baptized members during the equally traumatic post-baptismal emotional slump which almost inevitably seems to come.

A short, high-powered, three-week "professional" evarigelistic crusade to boost a small-church membership would seem to be almost a complete waste of time and money unless a spirit of koinonia has already spread from that little congregation to include in its fellowship, according to the capacity of the group and the influence of the Holy Spirit, as much of the surrounding community as it possible.

The small church should find no restrictions on its viability from the high standards for church membership as set out in the

${ }^{7}$ The church fellowship should be something more than just a surrogate family. The individuals in the small church should become the closest persons to the candidates for membership and should stay with them in this position after baptism. Cf. "Meaningful koinonia (fellowship) must precede and accompany effective kerygma (proclamation) and diakonia (service)." Eugene C. Bianchi, Reconciliation (New York: Sheed and Ward, 1969), p. 118. 
Church Manual, as these do not seem to be a deterent for growth in any size church, ' but the very small emphasis upon the place of koinonia in accessions into the church is disturbing from the point of view of the small church, the life of which largely revolves around this characteristic.

Lay Involvement, Ministry, and Training

The Manual in its current form would seem to be not so much a teaching guide for the small church as purely a book of procedures. As such, some valuable things have been omitted, notably a developed ecclesiology. ${ }^{2}$ There are a few Ellen White quotations and an apology for organization, but that is about all. It would seem that J. N. Loughborough's book made a better attempt at ecclesiology than the current manual, ${ }^{3}$ and perhaps that is the reason why it has ". . long held an honored place in the Movement." 4 Maybe we should not expect such a subject to now be included in the contemporary style of the Manual, yet without it a serious weakness seems to remain with the book, if it is to be instructive for use in small churches. 5

The Manual sets out the requirements for local church

Kelley, pp. 119-132. ${ }^{2}$ Church Manual, pp. 25-31.

3J. N. Loughborough, The Church, Its Organization, Order and Discipline (Washington, D.C: Review and Herald Publishing Association, 1907).

${ }^{4}$ Church Manual, p. 21.

${ }^{5}$ This is particularly apparent because of the dearth of Seventh-day Adventist material on ecclesiology--it seems a neglected and fruitful area for Adventist scholars and writers. 
officers, with heavy weight given to the responsibility of each office--particularly elders and deacons. 'The language is highly task oriented, maybe unavoidable in a manual, but it can contribute toward developing leaders who are primarily task oriented instead of people oriented. This renders the job and character descriptions in the Manual deficient with respect to the needs of the small church. ${ }^{2}$

With the emphasis given to chains of authority in administration, intensive job descriptions, and character requirements, lay involvement could be subtly discouraged and so could willingness to enter into training programs. ${ }^{3}$ The small church partly compensates for this by its inherent characteristic of involving higher precentages of its members in leadership as the size of the church decreases. $^{4}$

Brief counse 1 is given in the Manual for the training of young men as deacons and this is good, but one wonders if a broader aspect of training throughout the descriptions might not better contribute towards lay involvement in ministry than the present sole

${ }^{1}$ Church Manual, pp. 81-95.

${ }^{2}$ Perhaps then the Church Manual itself is at least partially to blame for the present unfortunate situation whereby knowledge of, respect for, and application of the Church Manual seems to decrease in roughly direct proportion to the size of the local church!

${ }^{3}$ E.g., using materials found in: B. Rogillio, "How the Spiritual Gifts of the Laos Can Be Called Forth. . . " (D.R.E. thesis, Southern Baptist Theological Seminary, 1971; C. F. Christiansen, "Training Lay Persons to Engage in the Ministry of Caring" (D.Min. thesis, Drew University, 1979).

${ }^{4}$ See Wicker (1969), p. 281. 
emphasis upon job demarcation and character and performance excellence. 1

Perhaps a whole new section is needed in the Manual on layinvolvement and training, and this may require a major revision of church departments and leadership roles. ${ }^{2}$. It seems that current moves to see the Sabbath School class as a witness cell could be a forerunner of other changes which would help tie the whole church and the departments into a total involvement of the laity in ministry and witness. It would seem that such changes would also need different emphases, viewpoints, and guidelines in future editions of the Manual, changes which would most likely involve a reduction in rigidity and autocracy but not in church standards, warmth, and decorum.

Such moves, from the standpoint of the small church, shouid be encouraged. The small church would profit if it could evolve these Biblical views on its own and see that its own natural personality as a small church involves an every-member ministry and a responsibility first toward those in the worshiping family and then to those still in the world outside.

IFor example, Loughborough presents the Shepherd, undershepherd, and sheep analogies with warmth and tenderness, and in such a way that there is no restriction to just the elders or deacons. Anyone in the church could read these Scriptures and Spirit of Prophecy extracts and see that they were deeply involved in shepherding and ministry too. Such is hardly possible in the stark job descriptions of the current Manual. E.g., Church Manual, pp. 75108.

${ }^{2}$ As well as many recent works on lay training, there has also been a renewed interest in John Wesley's "class meetings" of the Methodists. 
Worship and Mission

It may seem strange to link worship and mission together, and yet how a church worships powerfully expresses its philosophy of mission. As a church gets bigger, its worship services seem to become more structured, its hymns more measured and stately, its prayers more formal and ponderous, its sermons more phrenetic than cardiac. These things can be helpful and may be an improvement in worship standards, but small churches usually seem resistive to this type of worship "improvement" and their resistance seems to come more from a basic "biological" characteristic rather than just obstinacy. Could it be that the small church clings to its gospel songs, for example, because to them they are expressive of "family," whereas the formal, dignified hymns are not? It is worthwhile for leaders of worship to attempt to educate the smal1-church congregation to at least attempt to appreciate some of the fine, old, "stately" hymns and to point out, gently, that often their theology is more correct than some of that presented in gospel songs. But the weaning would be very difficult because to the small congregation it would be a move away from warm family fellowship. Similar attitudes are sometimes involved when sermons leave the emotional, family feelings behind and move into more philosophical, logical expositions. It would seem that a better rationale may be needed than a personal desire or conviction to "improve" singing or sermons in the small church. A study of the peculiar characteristics of the small church may make leaders of worship more cautious about attempting radical reforms which may actually be running right against the small-church personality. 
Hence the small church's view of mission, as seen through its worship service, is one of embracing people into the fellowship of the family. It, by nature, would place this even above mentally "converting" people to the family theological views, and in its mission it should therefore present this natural fellowship characteristic to the world before (in time) and in conjunction (i.e., of equal importance) with its kerygma.

As far as the Manual is able, the section on the worship services appears to cater reasonably well to the small church and, in fact, seems to have been compiled by people aware of the needs of the small church--even to the point of being biased towards that size of congregation. E.g., "We do not prescribe a set form or order for public worship. A short order of service is usually better suited to the real spirit of worship." 1 A shorter and a longer order of service is suggested, leaving room for flexibility in design around a basic framework, and the good worship practice of alternation between the message from the Lord and the congregational response is at least allowed for. ${ }^{2}$

The Manual notes the need for hospitality to be exhibited at the worship services ${ }^{3}$ and says, "A spirit of hospitality should be cultivated in every church." The note is made that attention should be given to the welcoming of visitors to worship services, yet if hospitality is not spontaneously shown by many within the church, not just an organized "welcoming" group at the door, the visitor quickly

\footnotetext{
${ }^{1}$ Church Manual, p. 113. ${ }^{2}$ Ibid., p. 116.

3 Ibid., p. 112.
} 
senses it and feels slighted from true fellowship. The ability to project hospitality naturally varies from quite difficult in a large church to very natural in the smallest. When a small church has "to work at cultivating hospitality" something is wrong, it is sick, for a healthy small congregation should naturally exude fellowship and hospitality. Perhaps that congregation needs to look at its relationship with Christ and His Gospel call--for most likely something must be wrong in this basic Christian tenet.

\title{
Administration and Structure
}

\section{Denominational Guidelines}

At higher levels

The Manual proposes that the Seventh-day Adventist church follows a representative form of church government and says: "This form of church government recognizes also the equality of the ordination of the entire ministry." I It would seem from the context that "the entire ministry" is referring to the "professional clergy" and hence seeks to expound an equality amongst these in distinction from the episcopal and papal systems. If this is a correct reading, then it would indicate that the doctrine of the priesthood of all believers is understood in a limited sense only, when it comes to higher church governing bodies. It seems that in common with most other Protestant churches, laity voting power has meaningful input only at the local church level and, possibly, at the next stage of administration (in the case of the Adventist church, the local

\author{
$8: 236,237$.
}

IIbid., pp. 46, 47. Cf. Ellen G. White, Testimonies, 
conference level). Above this stage, laity input seems to be more of a token with real decision-making power lying with the clergy.' It is agreed that at these higher levels deeply spiritual people are needed and only they are really able to take a broad overview and make widely effective decisions. Yet to equate these people as only being found amongst the professional clergy seems to be unfortunate. The human dynamics which produce apathy and weakness in a local church, when the people themselves do not make the decisions effecting them, still operate toward plans and projects coming from higher levels of government. ${ }^{2}$ Whether such effects in people are justified or not, they happen, and it would appear that as Management by Objectives operation of the local church (whereby the people make their own goals, plans, objectives, and action strategies) can revitalize church operation, so a similar effect should be obtained with a higher degree of lay democracy at the upper levels of government.

It may not be practical or feasible to have many lay members on Union, Division, and General Conference operating staff or executive committees, as these are in many cases full or nearly full-time situations, but it should be possible to have strong lay representation on the voting delegate bodies at the various levels. Perhaps a lay representation of 50 percent of all voting delegates is not an unreasonable aim. It would mean that delegates elected by the

${ }^{1}$ Compare: Chester A. Pennington, Half Truths or Whole

Gospel? (Nashville: Abingdon Press, 1972), p. 23.

2 Is it possible that the lay-input into local conference levels makes this body the most powerful in real terms? 
various executive committees to attend the Union, Division, and General Conference sessions would eventually be composed of 50 percent lay men and women, and 50 percent would be from the denominationally employed. The argument that only the clergy is really familiar with prospective candidates for leadership positions is hardly a good one and possibly points out other problems that need to be corrected. Also the solution that would have the clergyman nominated as a "clergy" delegate and his wife as a "lay delegate" hardly does justice to the aims of this suggestion or to that of equality of the sexes in decision making. The logistical problems in implementing such a suggestion may be many, but it would show that the church is in earnest in its belief in the ministry of the laity and democracy in church operation. Such a program may have to be introduced slowly in some third world divisions, but it would eventually mean a change, for example, at the General Conference session where delegates (particularly from outside North America) are presently overwhelmingly denominational employees and their spouses. It would testify to church members and to the world that the Adventist church is a church of the people and the local church--the small church in particular ${ }^{1}$--and not a church dominated by hierarchy and institutions.

$1_{\text {With over }} 60$ percent of the churches in North America below one hundred membership, and over 80 percent below two hundred, it means it would express that Adventists really do believe in the authority of the small church when lay folk from them can be elected to governing bodies even when it involves the world-wide organization of the denomination. 
Organizational cautions

Strong organization can be both a blessing and a curse to the small church. The Manual stresses throughout the value, need, and method of strong organization, with guidelines as to how the leadership in the local church can further this. ${ }^{1}$ Counsel is given for the protection of the churches against radical or schismatic attacks against it from within and without, and emphasis is placed upon developing respect and obedience to leadership. This counsel is needed and valuable if the local church is to operate both as an army and also as a family. Both analogies apply to the church and both must have firm, good rules with respect and obedience to leadership. Yet the tendency in religious organizations seems to be that when discipline and organization grows stronger and more rigid, powerlessness, disinterest, and inactivity grip the laymembers. ${ }^{2}$

It would seem that the battle to justify strong organization has been fought and won long ago, ${ }^{3}$ and there is a real danger that the church could err on the side of over-organization and develop a

1E.g., Church Manual, pp. 20-24: 40-49.

${ }^{2}$ similarly in the practical ministry and theological areas, when orthodoxy and traditionalism is promoted by a strong conservative organization against new proposals, ideas, and methods, then progressive innovative ideas and even "truth" can be rejected as "liberal" or heretical. Biblical and church history bears a sad testimony to the fact that it has been the strong defenders of orthodoxy who have been foremost in attacking and restraining God's cause of advancing truth. E.g., Pharisees versus Jesus; Aleander, Eck, et. al. versus Luther; mainline churches versus Millerites, etc.

${ }^{3}$ If the pendulum should swing too far the other way it may have to be fought all over again, but fear of that should not cause administrators to prevent it from finding the position of greatest power--in the middle. 
hierarchical monster of sorts. In such an unfortunate situation the undoubted strengths of congregationalism would be lost and local church apathy would be almost complete--in spite of strong persistent calls for loyalty, revival, and reformation from the leadership.

\section{Program Initiators or Reactors}

The previous section looked in particular at the higher levels of church government from the point of view of the small church. Now I would like to expand the concept introduced there of lay ownership of decision making, plans, and programs in the local church. When organizational development squeezes out local and individual initiative, innovativeness, plans, and power, then vitality is sapped, apathy takes over, and, at best, a caretaker subsistence existence ensues. ' This seems to be particularly effective in anaesthetizing small churches, but it effects a11. When leadership in the local church itself is autocratic, or rule is by oligarchy, the result in the individual members is the same--and the results are particularly obnoxious and devastating in the smaller sized church. Despotism, whether benevolent or not, has too often arisen in small churches. Inevitably inaction results or a violent eruption wrecks the church.

"The church" with its structures, organizations, and powers exists exclusively for the sake of the congregation. There is in the church nothing higher than the congregation. All ministries of the church are related to the congregation and are put to the test by the mature congregation. From its side, the congregation is mature to the degree that it no longer experiences itself as being taken care of ecclesiastically

IWitness the poor production of state-owned collective farms in communist countries, for example. 
and tended to by ordained officials but rather becomes the independent, responsible subject of its own history with God. Only then can Christian freedom be experienced in the congregation, for only then will the congregation be experienced as the free zone of the Spirit of God.

In the hierarchical church with its splendid buildings and its wise authorities religious power was and is experienced as a reflection of the fatherly sovereignty of God in heaven. But God as love can be experienced and represented only in the comprehendible congregation in which one sees and recognizes the other, and accepts the other as he or she is accepted in Christ.

The gospel of the Christ crucified "for us" puts an end to religion as power and opens up the congregation's experience of God, the experience of love: Justifying faith thus puts an end to religious belonging and creates freedom in community. . . . It is possible that out of a church for the people which takes care of the people, there could come a church of the people, a congregational church. This is possible whenever and wherever the energies of the Spirit in the congregation are set free and no longer dampened.

The Church Manual does seem to reflect more of this paternal attitude toward administration and leadership than one that is relational and equal, as suggested in a more Trinitarian model favored by Moltmann. According to the Manual: "All church officers, including the pastor and elder, should cooperate fully with the conference officers and departmental secretaries in carrying out all local, union, division, and General Conference plans." 2 Such a statement is possibly necessary, for the polity of the church is a conference model and not congregational, but as a control against hierarchical development and the loss of local congregational dignity and power a balancing statement such as the following should perhaps be included: "All conference officers and departmental secretaries as representatives of the local, union, division, and General

\footnotetext{
1Moltmann, The Open Church, p. 115; cf. Rahner, pp. 56-60. ${ }^{2}$ Church Manual, p. 87.
} 
Conference should cooperate fully with the local church in carrying out its plans."

Such a statement may seem radical, but it would show genuine recognized power lying within the local church--even the small, seemingly weak congregation--and would make a reality of the recognition by the Manual that the Conference departmental leaders are to be "advisors" to the local churches."

\section{Faith Action Advance 1979}

It is good to see that the North American Division has implemented a program based upon power and witness in the local church. Voted in April 1979, Faith Action Advance (FAA) ${ }^{2}$ makes a real attempt to put goal setting, implementation, and re-evaluation back into the field church where the action must really take place if the church is to be "the church" in the world and carry out the Gospel commission.

The program outline recognizes some serious weaknesses in past methods and attempts to meet some of the characteristics and needs of the small church, such as already presented in this paper. Briefly noted are some of the areas of strength in this FAA plan and also some reservations.

A real attempt seems to be made to make this a totally new

I Ibid., p. 183. Presently the Conference president is to ". . counsel them regarding their activities and plans" (p. 182). The role is decidedly paternalistic and possibly needs to remain so, but with a greater tangible recognition of the goals and plans of the local church.

${ }^{2}$ This is the name of a program to initiate a Management by Objectives style of church operation in the North American Division of the Seventh-day Adventist Church. References to the planning manual for this program will be noted in this section as FAA. 
way of thinking about both the church organization and the local church--and the interaction between the two. This appears so because, for perhaps the first time, a program is initiated which puts the goals and planning into the local churches themselves instead of formulating them at higher levels and handing them down for the local church to implement. Since certain procedures have been followed in the past, there may be a problem for pastors and conference leaders to change methods, even after experiencing the rationale in training seminars. The temptation to "push the program along" down the line from the division to the local church could still exist. Some encouragement to keep working on the plan may be needed from above, but caution also may be needed to keep the goals at the local church end--with interaction between levels-rather than the old way of power, pusin, and authority flowing down from the top in an attempt to motivate the members in the local church. Two good things flow out of the plan for the small church: (1) much of the rationale of FAA fits in with the characteristics of the small church. It is not just another program taken from some "successful" group somewhere, "adapted" at the General Conference or Division levels and then sent down the line to all churches to be implemented and so "finish the work." Small churches are often bewildered by such programs, they don't see how it matches with them or their community. The blindness may really lie with them rather than with the program, but the fact that it didn't arise from their midst, specifically tailored to their community, there is little hope that it will be implemented. Now a church, with FAA, is encouraged to set its own goals, suggest its own ways of meeting 
these goals, find out its own peculier talent and gift mix, implement on a continuing basis its own strategies, and then evaluate itself. It means that the small church, already living with an inferiority complex, does not have to add a guilt experience because it fails to match up with Conference goals. Excuses for failure because Conference goals cannot be met would become invalid. It takes away excuses for failure, because ultimately the church remains answerable to itself and this should prove a better motivator than pressures and proddings down the authority line.

(2) Some of the rationale for FAA does not seem to fit the characteristics of most small churches. By this I mean that FAA, as presented, is goal oriented toward accomplishing a task or tasks, but small churches are not basically goal or task oriented. They are "people" or "relationship" oriented--hence their protlem when the Conference was driving towards goals. Yet FAA is good for small churches because it encourages them to discipline themselves into setting their own goals. Uniess guiding organizations and small-church pastors allow and perhaps even encourage the goals to major in the area of personal relations, the program could have difficulty getting off the ground in small churches.

In the PERT chart the program is shown as being launched directly in at the local conference level, and this seems to be a progressive move to get it in as close as possible to "grass roots" level. Yet I wonder if it is more idealistic than realistic. I would imagine if and when FAA is introduced in Divisions other than

1PERT means: Program Evaluation and Review Techniques: It deals with events, lines of dependence and elements of time. FAA 1979, p. 7. 
the North American Division it certainly will not be the reality, for I cannot imagine it coming in any way other than down the line from the General Conference, to Division, Union, local conference, and finally the local church. It may have been better to face this situation in the beginning, for the current experiment where the Union and Division remain in the background probably will not become actual reality.

The aims as listed in the FAA document fit well with the philosophy of the small church. ${ }^{1}$ The FAA concept of the church is a step forward, beginning: "More and more we must view the church as a fellowship of believers--the koinonia of the New Testament. It is people in fellowship with each other and in fellowship with God...." ${ }^{2}$

This concept is most powerfully true in the small church and hence, in a sense, as this fellowship increases with diminishing size, a church should become even more "the church" as it gets smaller. If small churches could ponder this important aspect, it could help alleviate them from their feelings of weakness, inadequacy, and inferiority. This of course must be balanced with the increasing problem of meeting various need fulfillments with diminishing size which strains the fellowship.

Each of the seven dynamics of FAA seems to be a step forward from the outlook of the whole local-church aspect, but particularly that of the small church, e.g., Spiritual Preparation, Spiritual Leadership, The Concept of the Church, The Meaning of Ministry,

$$
\text { IIbid. } \quad 2 \text { Ibid., p. } 14 .
$$


Spiritual Gifts, Implementation and Strategy, Follow-Up/Through. The PERT chart looks at each of these seven dynamics as they are designed to be implemented in the local conference pastoral-and leadership-training seminars and then in each local church. Further illumination is given on a more biblical view of the church:

The local congregation becomes the action unit of the church at large. Thus it is imperative to understand the church as a place of fellowship and as a fortress in the world, with a mission to the world. 1

The three-fold aspect of mission as exemplified in the life and teachings of Jesus is clearly presented in FAA as the foundation of mission for the church today--Proclaiming, Serving, Fellowship. ${ }^{2}$ I have some reservation about the aim of fellowship as given here: "(3) Developing Christian community and fellowship in the churches by spiritually nurturing and equipping the belivers for witnessing and service." ${ }^{3}$ It seems to be giving the concept of "fellowship" a twist which makes it heavily task oriented, almost as if afraid that loving interaction purely of itself between "family" members and visitors is not enough without giving it a task-oriented goal. The aim as stated could be accepted perhaps by a large church with its cell groups and society orientation, but a small church with its

IIbid., p. 20. Cf., "The church with mission is God's people in the world called out of the world to go back into the world in order that the fellowship might be enlarged. Church growth then is based on the idea that the church is out in the world giving an account of its faith. The local congregation is the action unit of the church where all this happens" (p. 14).

${ }^{2}$ Ibid., p. 35. Compare, with slightly different arrangement for goals: Waldo J. Wearning, Vision and Strategy for Church Growth (Chicago: Moody Press, 1977), p. 50.

$$
3 \text { FAA } 1979 \text {, p. } 35 .
$$


family outlook may be uneasy about it. The fellowship aim, perhaps acceptable as far as it goes, hardly grasps the powerful "pure" fellowship dynamic present in the healthy small church, which is probably the strongest weapon of the small church for evangelism.

A refreshing feature of the FAA program is its recognition of the place of koinonia (in the small church context--"family fellowship") in the evangelism of the local church:

The very beginning of the process of making disciples is when the church reaches out to others. . . That process continues in earnest when the individual who has responded to the Holy Spirit deepens that experience by listening, learning, and fellowshipping within the church.

Before baptism the individual will consider a particular local church, his church; the pastor, his pastor; the members his friends.

The ability of the small church to provide such a fellowship environment is difficult to equal in a large church, and upon the presence of this fellowship climate hinges the success of the evangelistic mission of the small church.

In recognizing the importance of continuing education for "old" and "new" members alike, the FAA document also notes the close interaction between spirituality, education, fellowship, and witnessing, and hence presents a balanced and accurate picture of the dynamics of a vital church. ${ }^{2}$ This viewpoint is tangibly expressed

I Ibid., p. 29. Cf., "In order to sustain a member of the church his/her social needs must be found in the church and its life style. Therefore priority is to be given to planning the worship service, socials, and activities in the atmosphere of a true inclusive fellowship" (p. 63).

${ }^{2}$ Ibid., p. 34. For a model of small-group leadership training, see Alex $N$. Nemeth, "The Training of Leaders as Coordinators for the Experience of Koinonia in a Small Group Setting" (D.Min. thesis, Drew University, 1979). 
in the recommended training to be given the adult Sabbath School teacher who is to become the central leader of the witnessing groups (formed from the Sabbath School classes):

Before there can be effective witnessing in the church, the church must be united and families within the church must be united. This seminar seeks to build strong family units within the church and effecfive communication between all members of the family of God.

The health of the nuclear families within the church largely determines the health of the church family, and this seems to become more obvious and pronounced the smaller the church congregation.

In summarizing FAA from the viewpoint of the small church, it would seem that in both philosophy and practice it very much fits in with the characteristics and "personality" of the small church. It presents a refreshing view of biblical ecclesiology and, in fact, suggests a good apology for the small church.

My major reservation lies in the fear that FAA will be received too tritely as "just another program" instead of a major change in direction of authority, goal setting, and implementation. It must be grasped by the leaders and pastors first of all for what it is in its overall scope and aim. If they remain unconvinced and/ or inwardly threatened, then it cannot work under their leadership. Just as the introduction of this type of Management by Objectives program in a local church hinges on the pastor being fully commited and leading the action, so this FAA aim of extending it over all of the North American Division relies on the dedication of the

IIbid., p. 44. 
leadership to the plan. It would be unfortunate if the overall aim is missed and pieces of the program are lifted out, promoted, and pushed down the traditional goal-setting, motivation channels.' Such a fate would be particularly unfortunate for the small church which stands to be duly elevated and renewed under a faithful application of FAA.

\section{Fellowship and Growth}

Relationship with Sister Churches

The Manual seems to be rather silent about fellowship among different congregations except for cooperation for church school and public relations purposes. ${ }^{2}$ From my own experience it seems that little interaction and fellowship takes place between sister churches. This is unfortunate for the warm family fellowship which should normally be present in a small church should flow out to sister churches. Instead, a rivalry or competition almost exists among churches within fairly close proximity. Rather than ignoring or feeling threatened by one another, small congregations should work together to mutually boost their own viability. From earlier studies ${ }^{3}$ it would appear that amalgamation among congregations should be approached with caution. Churches are not inorganic objects, they are living

IFor example, the suggestion of making the adult Sabbath School teacher the leader of a missionary group formed out of his class. In some areas a similar fate seemed to have happened with the Stewardship program, which in a way was to be an MBO-type program.

${ }^{2}$ Church Manual, pp. 168-174.

3 For example: Allan W. Wicker and Claudia E. Kauma, "Effects of Merger of a Smla 11 and a Large Organization on Members' Behaviors and Experiences," Journal of Applied Psychology 5.9 (1974), 1:24-30. 
organisms and when transplanted they often reject the new amalgamating individuals. ' Yet when small churches look at themselves honestly--appraising their strengths and weaknesses--then jointly look at themselves with other churches, the differing characteristics could help meet unmet needs in both groups by some combined activity. Many small churches are so isolated from others that any meaningful joint activities are not really practical, yet even here, sometimes a concerned larger church could send teams of young people at certain periods through the year to run programs in quite distant small churches. These visiting young people may not be viewed as "family" by the small church at first, but after a few visits the few young people in the small church will look upon the visitors as "extended family." If the youth of the small church accept others as "part family," the rest of the church wiil quickly follow because they operate as one cell. Larger "smal1". churches (i.e., 150-250 members) could do more in a "big sister" role for smaller churches without becoming a threat to the small group-particularly if distances are fairly great.

The implementation of FAA should open the way for churches to look at their communities and their own gifts and talents. It could well be that gifts revealed in one small church could be used in the mission territory of another small church and so interaction among small churches would not only more efficiently evangelize the territory (say in a large urban or suburban area) but would pull

'Further research beyond Wicker's needs to be done on the amalgamating of congregations, but from personal experience it seems that it should always be approached with great caution and investigation. The sum of two "weak" parts may not make a stronger whole. 
sister churches together in a stronger fellowship--the aim not only of FAA but also of the Lord in having a united world-wide body to receive the Latter Rain, and be prepared for His return.

The Manual gives three reasons for disbanding a church:

(1) loss of members, (2) disciplinary reasons, (3) apostasy. ' The Manual suggests that the second happens extremely rarely and the third is not common in North America. Usually the reason for disbanding is loss of members. The process of disbanding given is of necessity cold and formal, and yet it is describing the possibly avoidable death of an organism. ${ }^{2}$ Perhaps a formal amalgamation with another church, if possible, may be better than the trauma of a disbandment, but even this seems to carry its own "cultural" shock. In ecumenical movements of amalgamation, the process has been slow.

It must be admitted that these often involve congregations of different denominations; but even in congregational cooperation on mission projects, of the many hundreds of attempts over 50 percent fail before three years and few last five years. ${ }^{3}$ Schaller gives some

${ }^{1}$ Church Manual, pp. 260-263.

${ }^{2}$ Hollis L. Green, Why Churches Die (Minneapolis, Minn.: Bethany Fellowship, 1972). Green would probably summarize his excellent material into four lacks: message, goals, leadership, and love: Some writers have suggested, when disbandment cannot be avoided, that it should be approached as one would a funeral, with a funeral service, and a pastoral climate to help the disrupted members through the "grief" period. The suggestion does at least show the importance of recognizing the organic nature--particularly of a small church--and the almost "biological" attachment of the members to it. Cf. M. J. Clingenpeel, "Southern Baptist Churches which Disband: Implications for Theology and Terminal Ministry" (Ph.D. thesis, The Southern Baptist Theological Seminary, 1979).

${ }^{3}$ Lyle E. Schaller, Creative Congregations (Nashville: Abingdon Press, 1972), p. 110. 
recommendations for cooperative ventures: (1) involved laymen planning from the very beginning; (2) beginning with realistic goals; (3) avoiding arguments over buildings and real estate; (4) advertizing widely the results of the effort--as this will encourage participating churches and others. It would seem from the Lutheran nine-church parish experiment in Kansas, noted by Schaller, that cooperative ventures could be done quite successfully, but with each church retaining its own meeting house and church services.'

Probably such an arrangement could also work in small Adventist churches if Schaller's cautions were followed. Yet the dynamics of the small church does not engender them by nature into cooperation with others. If such moves do not come from mature grassroots lay leadership, the hope for lasting success is about zero. Education, such as that provided in FAA, should not only help small churches in goal setting and spiritual gift recognition, development, and utilization but also assist them to see their true valuable place in the larger body of the church and in relationship with sister churches.

\section{Auxiliary Organizations and Groups}

From dealing with interchurch fellowship and its relation to growth, I would like to turn attention to the inner auxiliary organizations of the small church and their part in the viability of the congregation.

Basically they have been traditionally designed for task accomplishments--education, advertizing the church, helping others,

I Ibid., p. 112. 
etc., yet their one purpose has undoubtedly been mission--to carry the Adventist "message" into the world. But the small church, with its "relational" rather than "task" orientation, has neither been enthusiastic about goal setting for "tasks" or particularly enthusiastic about taking the departments of the church very seriousiy. In practice the departments ${ }^{1}$ have served another purpose, at times little admitted, to provide not only an opportunity for people to do something for the Lord in an area which they enjoy but also to provide a climate in which the individual needs of the congregation can be met. People need to have an outlet for their abilities and interests, to maintain their own emotional, mental, and even physical health. Yet, as Viktor Frankl points out, unless these are directed into ways which can be seen as helpful and positive toward others, little happiness and satisfaction result. ${ }^{2}$ The church departments can provide such an avenue for need fulfillments directed into active channels of mission, and particularly with the development of spiritual gifts in the smaller church, should the value of the departments become recognized and utilized. From looking upon the departments as mission channels into which any elected officer was expected to fit, with little regard for personal talent or gift, a more humanized and biblical role should emerge which will utilize the gifts and talents within the small church in the most efficient way.

${ }^{1}$ In looking at auxiliary organizations I refer principally to local church departments.

${ }^{2}$ Viktor Frank1, "Beyond Self-Actualization and Self-Expression," Journal of Existential Psychiatry 1 (1960): 5-20. 
In actual practice large churches in the past have utilized their departments to some extent as cells for people with like interests (hardly would the title of "spiritual gift" have been used or accepted), but few small churches followed suit--largely because of their one-cell, one family, church personality.

With the implementation of education in spiritual gifts, the small church should change its traditional lackadaisical attitude toward church departments. A view point which stresses the humanrelations role of the departments (inherent in spiritual gifts education) rather than their task orientation will greatly help the small church to do this. The departments can be seen as assisting the individual member to utilize his talent and spiritual gift instead of viewing them as a threat to the one-family concept of the small church. They can be seen as bones in the limbs of the iocal Body of Christ upon which they as individual members can provide the living muscle and tissue to carry out the Lord's work of fellowship and service through that congregation.

Very small churches may not have many or any department committees, and because of their primary-group philosophy they have no real desire, intention, or manpower to form them. They usually operate with a board and hold rare business meetings. The Manual says board meetings convene at least each month. ' Few very small churches follow this, but their goal setting and implementation of goals would probably be improved if they did. It may be better when implementing FAA and Spiritual Gifts to plan regular business meetings

' Church Manual, p. 131. 
and less frequent board meetings (to be held when needed), for the small church prefers to operate as a whole family rather than through an elitist group, such as a board. To be successful, the formidable formality of the Manual for business meetings should be modified.' It should take on more of a nineteenth century testimony meeting. It could be a time for informal reporting of gift and talent use over the previous period without an attempt to structure the program under rigid departments. With increasing church size, the structure of the business meeting also becomes more apparent, but a genera] loosening up and broadening of the present procedure would seem to be needed if departmental planning and reporting is to become meaningful to the small church under the new direction of FAA and Spiritual Gifts.

\section{Direction of Future Change}

It would seem that the basic structure of church operation as found in the Manual should remain, but when developments such as suggested in FAA are put into practice some changes will be needed if organization is to keep up with the dynamic movement of the real church.

One of these developments may probably be a deeper examination of ecclesiology and the role of the Seventh-day Adventist church in this historical development of the Christian Church. Developing from this could be a "liberalizing" of hierarchical structure, with real power and respect being returned to the local church. Within the local church itself, and even up the ladder of higher church

I Ibid., p. 134 
governing bodies, lay input and involvement would become a normal process. Growing out of this should be a deeper interest in the work of the church both locally and throughout the world. Probably the basic structure of the small church will not change very much. Hopefully, with development of spiritual gifts within the Body, the church departments will come alive--albeit in a less structured, probably more productive, way.

These suggestions are probably more my optimistic speculations from present trends than anything else, yet such processes are in action now which, if not arrested, could cause these developments. This should elevate the position and viability of the small church--provided it also moves with the times. 
CHAPTER IV

THE CHURCH AS FAMILY--IN THE LOCAL

OTSEGO MICHIGAN, CHURCH

\section{History of the Church}

Period of Growth--1861-1918

It is uncertain exactly how the Otsego church began, because when Joseph Bates came preaching through the district in 1859, some Sabbath-keeping Adventists were already in the area-although probably the two meetings held by Bates consolidated and added to the believers. In May of the same year, James White, another church pioneer and husband of Ellen white, spoke to a "large" congregation gathered in a tavern dance hall in the town. The Otsego church was formally organized in December 1861 and met, as they had done already for some years, in private homes until they opened their own church building in 1867--the same one still in use today. 1

It would seem that two laypeople, Aaron and Lydia Hilliard, who moved to the Otsego district from New York about 1855, were probably instrumental in gathering the first group of believers together in that area. ${ }^{2}$ Evidently the initial group began through

II am indebted to the church clerk's records, some of which are quite sketchy for the early period.

${ }^{2}$ So, according to one record, yet James white in the Review and Herald, 19 Niay 1859 , p. 204, records that upon his visit he was 
laywitness and was strengthened under the later evangelistic preaching of Bates and White, who were both undoubtedly strong "charismatic" leaders. Yet distinction between laypeople and "ordained clergy" was rather vague in the early days of the denomination, and it has been suggested that at the time of Bates'preaching in the 0tsego district he was in reality also a layman."

The church began with thirty-three charter members and continued to grow for another fifty years, during which time lay involvement seemed to be a key feature of the church, i.e.,

April 9, 1865--Aaron H. Hilliard elected as a delegate to attend the Michigan yearly conference; John Person and G. Leighton elected to visit some of the brethren, and Sisters P. Russell and Mary Hadden to visit some of the sisters in the church.

April 28, 1867--two men were chosen to "enquire into the state and standing of the young members of the church."

April 9, 1870--a committee of six was chosen to visit every member of the church.

April 16, 1893--each member was visited in an effort to eradicate any $i 11$ feeling that existed between members and provide for a brotherly harmony within the church.

Evangelistic meetings were held in 1863 by Elder Cornell

encouraged that the Hilliards would be joining them from New York. Cf. Arthur W. Spalding, Footprints of the Pioneers (Washington, D.C.: Review and Herald Publishing Association, 1947), p. 172. Cf. Review and Herald, 12 June 1855.

1 Perhaps particularly before denominational organization in 1860. Cf. "Otsego and Allegan Celebrate 90th Anniversaries," Lake Union Herald, 5 February 1962 
and Brother Lawrence; by Elders Corliss and Canright in 1880; and by William S. Ostrander in 1892.

It seems that a youth evangelism program was conducted in 1908, but a lay program begun in April 1915 does not seem to have been a great success. A proposal for an open Bible study on Sunday evenings was also rejected in June 1917.

The West Michigan Conference office was located in Otsego from 1902 to 1914 when it was moved to Lansing. Soon after the church membership, which had reached sixty-nine by 1906 and peaked at 117 in 1918, began a downward slide. In 1908, with a membership of seventy-eight, the church requested the conference to supply them with a pastor. They had operated for forty-seven years almost totally under layleadership. It was another seventeen before they received their first "permanent" pastor, Elder $W$. C. Hankins in late 1925. Such was the importance of the church business meetings in the early days that members were disfellowshiped for failure to attend them. These meetings were of a highly spiritual nature including a preparatory Sabbath testimony and confession service, an evening or Sunday meeting with singing, devotions, and prayer season, and the business meeting to conclude.'

Apparently generally good relations were maintained with other churches in the town, for in 1884, when Ellen White took a series of meetings there in November, "The Congregationalist minister very courteously offered to withdraw his appointment for Sunday

IGary E. P.usse 11, "The Otsego Seventh-day Adventist Church-A History" (Unpublished term paper, Andrews University, Michigan, 1974), pp. 8-10. 
evening, inviting Sister White to speak in their house, as it was larger than ours. Though the evening was very stormy, yet the house was crowded." 1

The first sixty years were characterized by growth (very slow until 1900) and lay leadership, with concern for lay-leadership visitation of the members. In the early 1900s Otsego had its own conference academy and its own local church school plus other facilities. Thus the presence of the denominational institutions probably contributed to the membership. However, only a few public evangelistic campaigns are recorded (there may have been more than the three or four), so it seems that for a variety of possible reasons only small emphasis was placed upon evangelistic crusades.

During the latter part of this period, the population of Otsego grew from 1,851 in 1894 to 2,812 in 1910 and 3,168 in 1920-the fastest growth period in the town's recent history.

\section{Period of Decline--1919-1972}

When the conference office moved to Lansing in 1914, evidently many families moved also, for al though 0tsego membership continued to rise until 1918, transfers away from Otsego rapidly escalated after that. Membership of 117 in 1918 dropped to 84 in 1922 and to 67 in 1923 where it remained steady until the end of the 1920s. There were wide fluctuations in the 1930s, from 54 in 1934

IArticle by D. M. Canright in the Review and Herald, 2 December 1884. It is not known if this relationship changed at all after D. M. Canright's apostasy to the Baptist Church in the town in 1887. 
to 74 in 1936, and down to 49 by 1940.1

It does not really seem as if the loss of the institutions in the town after 1914 was the real reason for the continual decline in membership, which reached a low of 21 in 1972 , the year the church closed.

During this same period the population of the town slowly grew from 3,168 in 1920 , to 3,245 in $1930,4,328$ in 1940 , and 3,990 in 1950. The population peaked in 1960 at 4,142 and dropped to 3,957 in 1970. This decline may have continued in the 1970s, but this will not be known until the results of the 1980 census are released.

In the Otsego church, this same time period seems to have seen spasmodic pastoral leadership for the first thirty years ${ }^{2}$ and fairly continuous pastoral guidance for the last twency-four years. Apparently 0tsego, during these latter years, was included in a parish with one or two other churches (Allegan and.Douglas) and the

IOnly three evangelistic campaigns are recorded as being held from 1918 to 1954; James Edson White in 1920; Lyle Shepard in 1937; and Dwight Wallack in 1951. The elevated membership of seventy-four in 1936 was caused by the transfer of membership into the 0tsego Church of twelve of the Adventist staff from the White Memorial Home in Plainwe11, which closed in late 1935. And the rapid 34 percent decline over the next four years was possibly caused by these same health-institution staff transferring their membership elsewhere. Membership in 1897 was forty-nine and in 1940 again forty-nine.

${ }^{2}$ Brother and Sister Piper were present on Sabbath, June 18, 1921, following which the clerk recorded that they were glad to have a minister present as ". . . we seldom hear a sermon." Two months later they again had a minister preach and recorded ". . . it was good to have someone to talk to them." For the JulySeptember quarter in 1927, the church had three ministers and one denominational doctor visit them--i.e., four sermons in three months! 
pastor probably conducted worship services every second or third week. Leadership, therefore, was shared between laity and pastor, but it would appear that initiative for action in the church was placed increasingly upon the "professional" leadership of the pastor. With two or three churches to care for, the pastor finds it difficult to do an adequate job of leadership, and in some areas he cannot begin to supplant good lay leadership. There are no notations in the clerk's records about concern for visitation of the members by the lay leadership., such as took place prior to 1900 , although doubtless informal and irregular visitation took place. Visitation for forthcoming disciplinary action and for financial pledging is mentioned--but no programs of organized lay-pastoral visitation seems to have been formulated. Good relations seem to have been maintained with other churches, at least in 1921 when the church building was rented to the Christian Reform Church for use on Sundays. ' In November 1937 and 1938 the church joined with a union of other denominations for a combined Thanksgiving service in the town. Membership continued to drop until it reached twenty-one in 1972. On December 23, 1972, Pastor Howard Greene called a meeting of the eight members who were present, all but one voted to close the church. It was voted that Dale Lamb write a letter asking the conference to take responsibility for the church furniture. On January 1, 1973, letters of transfer for all members were sent by Janet Lamb, clerk.

'Clerk's records for October 2, 6; November 24, 1921. This arrangement lasted until November 1929. In April 1931 it was voted not to rent the church to other denominations--the reason given for this is not indicated. 
In spite of the steady decline in membership, much fruit was born in the service to the denomination by the mission service throughout the world of many sons and daughters brought to Christ earlier in the history of this little church.

\section{Period of Revival--1973-1980}

The dynamics which were in operation in 1859-1861 were repeated in 1973 when the Otsego church was reopened. The real strength lay with a group of lay people who were willing to set up a church as a witness to the gospel in the town. But the key to the implementation of such a scheme lay with the initiative of men called to the gospel ministry who had a vision and a plan. As Joseph Bates and James White were instrumental in organizing the lay people into a church in 1860, so David and Monika Yancey, joined by Jack and Sandra Colclesser, were the primary initiators in having the church reopened. While a theology student at Andrews University, David Yancey preached at Allegan church one Sabbath early in 1973 . He heard that the Otsego church had been closed for some months, so he drove over to look at it. He was quite impressed with its structure, as well as its history, and purposed to do all he could to have it reopened. After consulting with the local pastor, Howard Greene, David visited church members who lived in the area and was encouraged by the number willing to re-restablish the church in 0tsego. Others caught his enthusiasm and vision, and hence, on May 12, 1973, the 0tsego church reopened with 120 people in attendance. On August 4, 1973, the church was officially organized with forty-four members, which increased to fifty-two in 1975, and went back to forty-eight in 1976. 
A notable feature of this revival period has been the assistance given to the local pastors by Seminary and theological students from Andrews University. This fairly continuous presence of students for eight years has provided good worship leadership when the local pastor is elsewhere (usually every second week). Another feature is the considerable distances many present members have to come to the church--preferring this rather than attending churches which may be closer but are much larger.

In 1973-1974 the church was completely remodeled inside, and a special homecoming day was held on November 2, 1974, to commemorate the renovation and reorganization of the church. The congregation has subsequently bought the house next door and work has progressed to restore this house to its original (pre-1900) condition and appearance. It is being used for Sabbath School and welfare purposes.

\section{Description of the Viability Project}

The small 0tsego church was virtually resurrected from the dead with the aid of ministerial students in 1973. As a Seminary student I, with my wife and children, began to attend the church during 1977. We took the place of another Australian Seminary family, Tom and Pam Ludowici who, with their children, were about to return home. Tom had organized a number of programs in the church, including the 1974 homecoming and a Marriage Enrichment Retreat, which seemed to encourage and strengthen the small congregation. The membership was holding at about the forty-member level 
and the church seemed to be stabilizing after the trauma of the closure and reopening.

The object of the Viability Project was to see how the members viewed themselves, the pastoral leadership, the community, etc., so that their present viability could be examined and goals and plans could be initiated for the future of the church.

It was decided that a fairly comprehensive questionnaire would be distributed to the members to ascertain how adequately they felt the church met their needs-socially, spiritually, vocationally, etc.--and how the church met the needs of the community. As the church had decided in early 1979 to run a series on health, believing they needed growth in this area, a pilot survey on health was run in conjunction with this. Of the thirty-six survey forms distributed on April 21, twenty-six were returned compieted, including one from a visitor. The results were interesting and informative, and the level of knowledge and practice of health principles were found to be fairly high.

On April 22, 1979, I met with the church board at a meeting chaired by the church pastor, Elder Carl Reibow. The board agreed to cooperate in the program and indicated an interest in assisting me in looking at their potential for growth and future development.'

\section{The Congregational Survey}

The viability questionnaire was distributed on July 14, 1979, and completed forms were handed back over the next few weeks. The

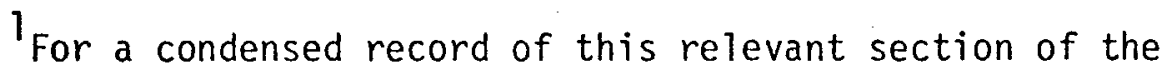
board meeting on April 22, see appendix C. 
questionnaire was in two parts--one a short two-page survey dealing with the member's baptismal record, musical talent, and sermontopic needs and interest. It was designed mainly to help the church pastors with their planning so that they could be the greatest blessing to the church. This first questionnaire could have the member's names included if he or she desired, the second larger questionnaire was to be anonymous. 1

It is believed that the church as a family has responsibility to others, not only to those within the family but to strangers outside the church. Therefore the questionnaire attempted to gauge attitudes which were indicative of members' feelings and involvement.

The project was not to just gauge the viability of the otsego church but rather to also compile a profile of the congregational viewpoint and then, from this basis: to set goals for the future growth of the church. Hence the project was optimistic in that it expected the church to evaluate itself as viable and to learn what they could do to make it more so.

There were sixteen of the first survey forms returned and fifteen of the second. The forms were only given to adult church members. Although the few visitors present were invited to participate, it is believed that all declined. The number returned would indicate about a 75 percent response of the regularly attending members. $^{2}$

${ }^{1}$ See appendices $D$ and $E$.

${ }^{2}$ The timing of the survey was probably not as good as it could have been--it was summer vacation time and the following two Sabbaths the church was closed for the Michigan campmeeting at Grand Ledge. 
The questions on the survey principally evaluated each member's attitude toward other church members, the ministry, and community, issues in the Adventist church, and mission responsibility. Hence, according to Reichert's eight family functions, 1 this survey of the Otsego church-family majored in the functions of philosophical, reproductive, protective, socialization, and personalization, only a few questions covering education and nurturant, and none concerned economic.

There were some questions involving particular Seventh-day Adventist doctrines, teachings, or practices, some of which might be considered controversial. The idea was to gauge the individual's grasp of these doctrines to indicate where the member stood in his or her Adventist educational "development" and his or her attitude toward a few current issues. The aim was to determine if this small church was in touch with the dynamic movement of the church at large. By far the greatest weight in the survey lay in the area of belief and practice for mission (philosophical--reproduction), as it was felt that this contained the strongest indication of future viability. Because the social structure is so important in the small church, this aspect was also given heavy weight. so that indications in this area might be apparent.

Individual growth, talent, and gift utilization have been mentioned as important in earlier chapters, hence the personalization function was fairly heavily weighted in the questions. The questionnaire aimed at gaining some indication of the family member's felt

${ }^{1}$ See chapter II and Rodgers, pp. 28-31. 
needs in education, only a little in the area of nurturing (involving personal counselling and visitation), and none in the financial function (economic). The absence of the latter may be a weakness in the survey, if finances are as big a factor in small-church viability as some authors suggest. ${ }^{\prime}$ I agree that most small Seventh-day Adventist churches are struggling to pay their bills--if not constantly as least seasonally, but I think that the major reason for problems are other than finances.

Perhaps there would be more carry-over into the nurturant function from socialization and personalization beyond that estimated, hence the nurturant factor may be more strongly represented than indicated.

The large questionnaire was probably too long--120 questions-yet it seemed necessary to include a large number of questions on the critical area of mission in order to gain a reasonably good profile of the church. There were a number of open-ended questions and also an opportunity to write in qualifying remarks or additional comments for many other questions. A fairly good response was obtained from this type of question and suggestions from these were fed into the group evaluation and goal-setting meeting held as a post-survey. The large questionnaire was divided into four sections:

(1) Fellowship, Ministry, and Mission, (2) Community and Social, (3) Beliefs, (4) Witness. There was some overlapping with individual questions, so there was no rigid demarcation between sections.

\footnotetext{
${ }^{1}$ See chapter II.
} 
Assessment of Results

Sixteen people responded to the short questionnaire. Some interesting results can be noted here. To Question 3: "If I knew my relative(s)/friend, who are not now members of God's remnant church, could hear only one more sermon before their death, I would want them to hear most of all about ...", a large proportion (seven) answered, "The love of Jesus for them." And to a similar question asking what topic the respondents would prefer for their final sermon before death, eight responded with "The love of Jesus for me." The topic they felt they needed the most sermons on was "forgiveness," second was "how to be patient," third was "how to overcome temptation," and about seven topics vied for fourth place. This survey indicated that the greatest felt need of the church was for a permanent pastor, and the second was a tie between a personal relationship with Christ and the need to win souls. To the question "One thing I would never neglect to do if I were pastor of this church . . .", a variety of responses were given, but the two most numerous were "to make visitors welcome" and "to visit members."

The factors most influential for baptism were many and varied (it was an open question), the most common was "conviction of Bible truths," followed by "a desire to become one of God's people." Yet though different people and wording were used in their responses (e.g., sister, mother, wife, children, etc.) it would appear that equalling or surpassing "bible truth" was the influence of relatives, loved ones, and friends.

The second, larger questionnaire was answered by fifteen people and surveyed a wider field. The scores are found in appendix 
$F$, however, some scores are noted here. ${ }^{1}$

The members seemed to be happy with their church experience $(3,8)$ but felt inadequately prepared to give Bible studies $(10,19)^{2}$ In response to questions concerning spiritual gifts $(16,69)$, six felt that they had the gift of exhortation, four believed they had the gift of faith, two indicated evangelism, and one each for teacher, administration, and stewardship. Five did not know what gift they had. ${ }^{3}$ When asked whether they felt they should be giving Bible studies (17), seven answered "no," five said "yes," but added that they lacked the necessary training, and two indicated that they were giving studies at the moment, i.e., 13.3 percent. (This is the same proportion as those who felt they possessed the gift of evangelism (16) and possibly involves the same people. ${ }^{4}$ ) Peter Wlagner suggests about 10 percent at the most would normally possess the gift of evangelism in a typical church, ${ }^{5}$ but of an average membership attendance of about twenty-six, the two would equal about 7.7 percent. The survey respondents indicated that witnessing for

The question on the large survey form is shown in parenthesis. In the first two sections of this large questionnaire, I am indebted to suggestions by Eoin B. Giller, "Building up the Body of Christ" (D.Min. project thesis, Andrews University Theological Seminary, 1977).

${ }^{2}$ See table 4. See appendix $E$ for questionnaire.

${ }^{3}$ See table 5 . See appendix $E$ for questionnaire.

${ }^{4}$ See table 5 .

${ }^{5} \mathrm{C}$. Peter Wagner, Your Spiritual Gifts Can Help Your Church Grow (Glendale: Regal Books, 1979(, p. 177. This question was a little leading in a negative direction and so perhaps increased the negative response. 
Christ was their number one priority as a Christian. (15), church attendance took second place. To the question, "To how many families or individuals had you given a series of Bible studies over the past twelve months" (19), ten replied "none," although ten also said they were devoting between "some" and "five hours plus" per week to some form of outreach for Christ (21). ${ }^{1}$ The questionnaire perhaps was deficient in not seeking to find out what kind of outreach was done. Probably the seven who felt no need to give Bible studies were included in the ten who had not given any in the past twelve months. Some of the seven also indicated "yes, but . . . ;" and interestingly enough, one who answered "no" also said he was giving Bible studies at present! It would seem that at least the five who indicated that they should be giving Bible studies but lacked training could be given more confidence with adequate instruction.

The respondents felt that they should be more involved in local community $(5,31)$ and social roles $(36,37)$, and there was a fairly good response to indications of willingness to help in specific programs. Good suggestions for the social activity of the church were obtained in the open-ended questions, and other helpful information was obtained for those planning future Vacation Bible Schools, Five-Day Plan to Stop Smoking, et cetera.

The order of priority given to the pastor's roles (13) went as follows: (1) Bible student and man of prayer, (2) preacher and leader of worship, (3) soul winner, (3) teacher, (4) church enabler-equips and helps members to minister to the community, (5) visitor,

${ }^{\top}$ See table 6. See appendix $E$ for questionnaire. 
TABLE 4

PESPONSES TO THE LAREE QUESTIONNAIRE

FOR FELLOWSHIP, MINISTRY, AND MISSION

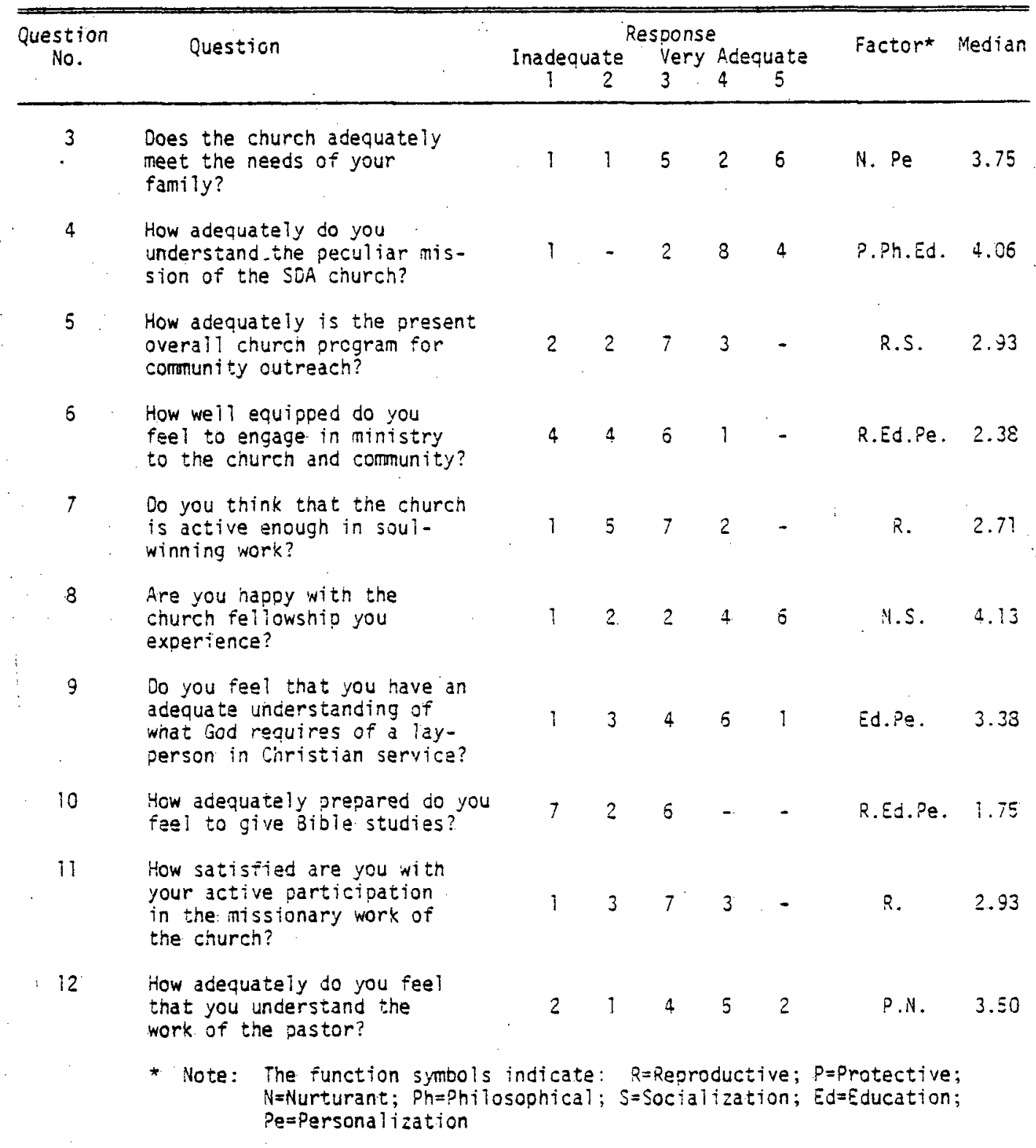


TABLE 5

RESPQNSES TO THE LARGE OLESTIONIJAIRE FOR MINISTRY AND MISSION

Question Order

No. of Rank

13 Which of the pastor's roles is most important?

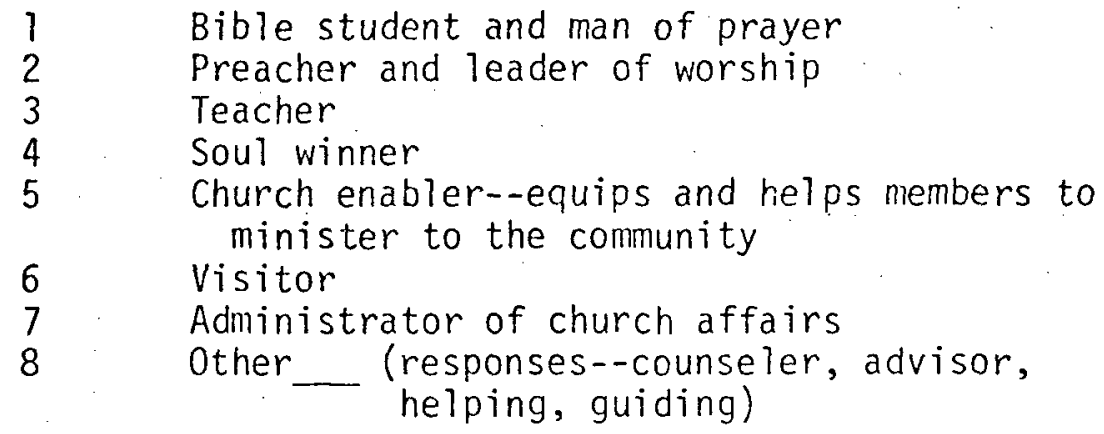

15 Which activity is most important to you as a Christian?

$\begin{array}{ll}1 & \text { Witnessing for Christ } \\ 2 & \text { Church attendance } \\ 3 & \text { Good deeds } \\ 4 & \text { Soul winning through Bible studies } \\ 5 & \text { Welfare work } \\ 6 & \text { Sabbath School attendance } \\ 7 & \text { Prayer Meeting }\end{array}$

16 Which one of the following spiritual gifts do you believe God has given you for Christian service? (Obviously some responded to more than one.)

Nos. Gift Evidenced

$\begin{array}{ll}1 & \text { Teacher } \\ 2 & \text { Evangelist } \\ 6 & \text { Exhortation } \\ 1 & \text { Administrator } \\ 1 & \text { Stewardship } \\ 4 & \text { Faith } \\ 5 & \text { Nor sure }\end{array}$


TAELE 6

RESPONSES TO THE LARGE QUESTIONNAIRE

FOP. WITMESS

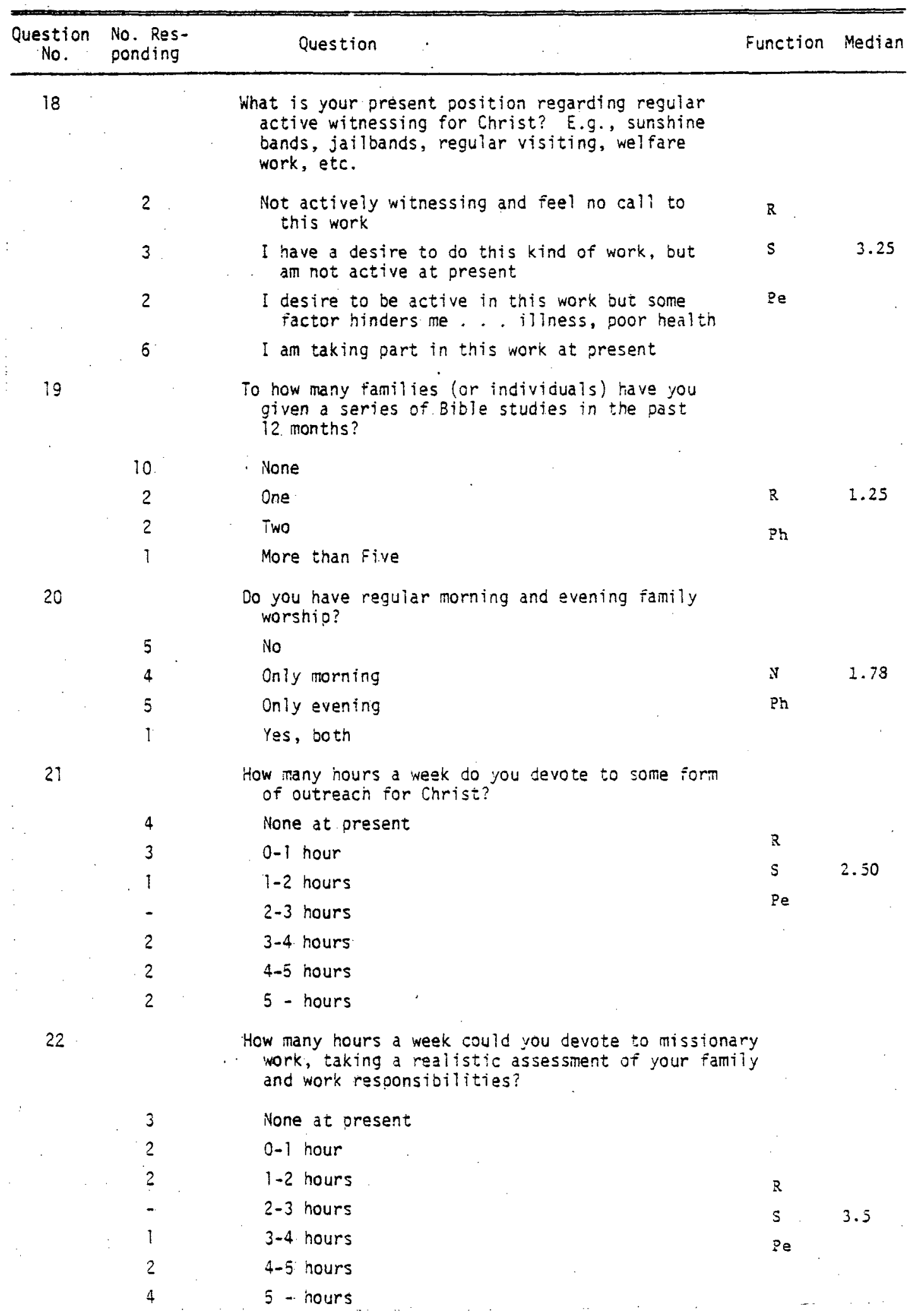


(6) administrator, and (7) counsellor.'

Only one person of the fifteen indicated that they had both morning and evening worship in their home, nine had either morning or evening family worship, and five said they had no worship at all (20). There seemed to be some tendency for the fifty- to seventyyear-old group to be higher in not having worship and this could be because of a single life-style with a number in this age group. ${ }^{2}$

In the second section on beliefs, it appears that this small church is fairly well aware of the current church climate, surprisingly so for a small country-town church. Maybe this is due to the presence, in addition to the regular pastor, of undergraduate and graduate Seminary students in the church for the past eight years. Seven of the members indicated that the NT taught others to be ministers as well as ordained pastors (six were uncertain). Although the majority indicated a correlation between health, dress, adornment, speech, and thoughts, et cetera, with salvation (49-51), eleven rejected any good works as contributing towards God granting eternal life (56, cf. 55 and 65 ). They did not believe in other ways to heaven outside of Jesus Christ (66), hence the basic evangelical platform for mission remains strong in this church. Related to this was the result which had eight declare that God's love was superior to His law, while four felt that law was superior to love (63). This somewhat philosophical question, possibly indicates the belief that God's love even surpasses His justice--which does seem to be the NT emphasis (only two were uncertain on this difficult question!).

$$
{ }^{1} \text { See table } 5 . \quad{ }^{2} \text { See table } 6 .
$$


The grasp of belief in the assurance of salvation seems quite strong, with twelve indicating that if they died that night they believed they would be resurrected to eternal life (three were uncertain) (58). There did seem to be some weakness in the doctrine of inspiration, with nine equating total inerrancy with inspiration while three remained uncertain $(60)$. The members did not believe in degrees of inspiration between Ellen white and the Bible, which seems more biblical (57), but they did tend to indicate that one true prophet could be more inspired than another (54). This subject is a current one under examination in the church and this small congregation does seem somewhat confused at this time.

They indicated confidence that the Holy Spirit had given them spiritual gifts (69)--twelve said "yes" and three were uncertain (cf. 16).

The topical question on the ordination of women split the members down the middle, four in favor, four against, and seven undecided. Twelve believed they would not take another Adventist or an Adventist institution to court if they were financially wronged by such people, three were uncertain (72).

A narrow, sect-type exclusivism in salvation doctrine does not seem to be strongly present in this church, nor is a legalistic outlook. In beliefs and doctrine they seem to have a good base to build on for future growth, and open-mindedness should encourage them to have open doors to the world outside. This already seems to be borne out in their recent congregational life.

${ }^{1}$ See table 5 . 
In the final section on witness it would appear that the church is quite optimistic about its mission role and generally knows the "correct" answers, but in practical application, both in this section and the first part, there does not seem to be appropriate performance. ${ }^{l}$ The grand mean for this section was a positive trend of 3.93 on a scale of $5 .^{2}$ As a self-appraisal of witness potential the reasonably high mean probably indicates that this is a receptive congregation to new-comers joining it. This has been well seen in recent practice and hence the elevated 3.93 is probably a gauge of the openness of the congregation to mission rather than the actual involvement of people in direct, tangible mission activity. Yet as earlier chapters in this study have indicated, the koinonia (or fellowship--probably showing up in this elevated witness score) is the small church's greatest potential for evangelism and church growth. Only one or two may have the gift of evangelism, but the healthy small church has the ability to surround the newcomers who are brought by the "evangelists" with an abundance of warm family fellowship which is hard to resist. The same fellowship surrounds the visitors brought to the church by members with other gifts. Sometimes it is hard to indoctrinate these contacts. These visiting people may have to learn doctrine in the worship services

IFor this last section on witness I have adapted some of the questionnaire material used by G. G. Bietz, "The Concept of Christian Witness" (D.Min project thesis, Andrews University Theological Seminary, 1976), pp. 156-158.

2 This "mean of means" of 3.93 showing an elevation above the standard mean of 3 , would seem to imply a good grasp of the concept of witness, by the respondents (the reliability coefficient for this section being a good .911). 
and later in pastoral visits, but it is the warm, family fellowship that can hold the visitors until doctrines can be understood and accepted. Such seems to be the method of growth in the 0tsego church.

\section{Family Functions}

The "mean" of the "medians" of the survey results when applied to Reichert's eight family functions are shown in table 7.

\section{TABLE 7}

$\begin{array}{lc}\text { Reproductive } & 2.63 \\ \text { Economic } & \text { not available } \\ \text { Protective } & 3.4 .8 \\ \text { Nurturant } & 3.16 \\ \text { Philosophical } & 2.60 \\ \text { Socialization } & 3.47 \\ \text { Education } & 3.11 \\ \text { Personalization } & 2.92\end{array}$

These results have not been tested outside this church and are a subjective application of what I feit were relevant questions to certain functions. Only the first two sections of the large survey were applied.

The scores seem to indicate that as a family the members feel secure (in this case spiritually, mentally, and physically within the congregation). In socialization within the group and in nurture (in that they have an adequate counseling climate) they

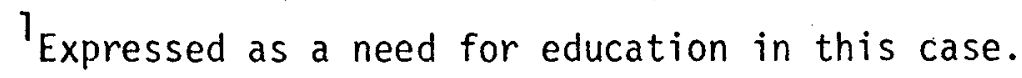


also appear to feel adequate. They also feel a need for education (primarily for outreach and mission), while their philosophical (spiritual, devotional climate) and personalization (personal growth and development of individuals) functions seem somewhat lower than they should be.

Their reproductive function seems to be operating below an acceptable level and this does not bode well for the future of the group, although they are reflecting this need in their desire for education in mission and witness.

As a family they seem to be in fairly good health, although reproductive weakness is fatal in the long term. They need further training for ministry--particularly in the utilization of their spiritual gifts--and continued development of their already wellexhibited family fellowship.

\section{Summary}

In summary of the survey results it could be said that the church is generally happy with itself. It believes it should be doing much more in the local community, that it does not have enough social activity within itself, that it is not doing enough in missionary work, and that its members do not see much need for changing their priorities. There is obviously some tension in the fact that the need for new members (voiced often in open-ended questions) and organic growth was at the top of the needs list, while the larger proportion said that they were not holding Bible studies, were inadequately trained to hold them, and almost half indicated no burden to study with people. Yet the larger proportion indicated their 
willingness to witness to their faith and six indicated that they actually were witnessing in some specific way--evidently they believed that they could win people to the church without having Bible studies with them. Obviously there is a place for disciples like Andrew in the soul-winning work, and evidently many in the church were in this category. In this survey and in an earlier health survey (in which nine of twenty-five indicated fifteen minutes a day or less in personal devotions) there is an indication of little deep scripture study--either in time or concentration (a)though four in the health survey indicated that they were spending two to three hours a day in personal devotions). It would seem that knowledge of scripture is being viewed as a possession principally of the professional. There was a desire to grow, but it seems to be restricted to tutored growth on the Sabbath. Evidently this is where education must begin, and an attempt was made to initiate this by introducing a Bible-marking seminar for several Sabbath afternoons. If this program is successful a strengthening of the philosophical function should result.

\section{Outgrowth of Results}

A well-advertised Sabbath afternoon meeting was held on August 25, 1979 to examine the survey results and set goals for the church--particularly for the next twelve months. The meeting was divided into three sections. First, the survey results, their meaning, and implication were presented. (This presentation lasted about forty-five minutes.) Second, the group broke up into three subgroups or cells to consider the results and to formalize one goal 
statement with some attendent subgoals and action strategies for the church. (This also lasted about forty-five minutes.) Finally one large group reconvened to examine the three goal statements and subgoals and from this to collectively produce one goal which would fit in with the evident viability of the church. Subgoals and action strategies to proceed toward that goal were then suggested.

About twenty-two people, including some interested visitors, were present for this meeting and after listening to the survey results and guidance for the goal-setting process, eighteen remained to join in the second part of the subgroup goal setting. The three groups of about six people each began work on the goal statement. One group was all ladies, another all men, and the third was mixed, yet the goals set were surprisingly similar.

The small groups joined as one large group and the goals developed by the smaligroups were displayed and discussed. From the three goal statements, one goal statement which they felt met the potential of their church, was formularized. They believed the church was viable enough to remain in existence, that they had a message and a ministry for the Otsego community, and that they could continue to grow. Their finalized statement of the otsego church said: "Our church is a gathering of people to worship and to spread the gospel. We see ourselves as being called to give strength and help to all, both within the church and also in the community."

Subgoals within the capacity of this small church were discussed and most in the outreach area centered around the completion of the renovation of the house next door to the church. Only 
relatively minor things needed to be done to complete it, but some influential folk in the group felt that it had to be completely finished so that the public could be invited to some outreach programs which were tentatively planned. Work on the house had come to a standstill. Only minor repairs were needing to complete the project. The group openly discussed the possibility that they had made the completion of the house a necessity before launching into any community outreach programs, and that they were holding back on the completion because they unconsciously feared putting church energy and gifts into outreach. They realized that this fear was not valid and made specific dates and goals for completing the house. Some of these have not been met and as yet, the house has not been opened as a Welfare Center.

They recognized the need for education in mission and spiritual gifts and requested a seminar in Spiritual Gifts to be followed by training in Bible marking and witnessing. A regular program of social activity was initiated and a person was elected to organize it.

On September 8, 1979 the first of two seminars on Spiritual Gifts was held with fifteen members present. Following the presentation three small groups were formed to examine some of the biblical

${ }^{1}$ Goal setting in a small church is a very fragile thing, for in this case unforeseen family and health problems have unavoidably delayed their plans. There is no reserve back-up force to replace "casualties" in a small church, for usually most things are,done with the only strength they have, and when that falters or fajls, the operation slows or stops. 
gifts. ${ }^{1}$ Each group wrote its conclusions on newsprint, reported its study to the combined group, and all entered into a lively. and informative discussion. The second seminar, held September 22, was attended by only members. The meeting concluded with a Hout's questionnaire for suggesting likely spiritual gifts. ${ }^{2}$ Two additional people, unable to attend the meeting, completed this test at home. A gift mix for the group was revealed which matched very closely that indicated by Question 16 in the survey.

Every two weeks following the Spiritual Gift Seminars, Bible-marking seminars were held. Attendance varied between seven and twelve persons. This program continued through the winter for six months, but many older members were unable to attend.

The questionnaires objectively obtained information about how each respondent felt over a broad spectrum of questions concerning church and individual life, thus revealing the viability of the church. The usefulness of a questionnaire seems to drop off a little in a "small small" church because each one in the group already knows a lot about the feelings and outlook (even the spiritual condition) of others in the church, and the members almost intuitivery seem to act and think as one. This has its problems as well as its positive advantages. But in this church some interesting

I I do not think that small groups (say five to seven members) operating within a large extended "smal1"group (e.g., a small church) are as dramatically effective as when they are used within a large "faceless" society, but in this situation they did operate smoothly and revealed the usual peculiarities of different people. mixes.

2 Modified Hout's questionnaire (Pasadena, Ca.: Fuller Evangelistic Association, 1978). 
viewpoints, suggestions, and ideas came to light which otherwise may never have been expressed. The pastor has some feedback on the congregation's views on sermon topics and their own felt needs in preaching.

The goal-setting meeting seemed to be enjoyed and proved helpful in clarifying direction and steps to reach goals. Although these were realistic, the meeting did point out the inherent weakness of the small church--a fully committed and under-manned group of leaders who do the work, and when unforeseen circumstances remove these people temporarily or permanently, the whole program virtually stops.

As an instrument to measure viability, the survey pointed out strengths in the area of koinonia (sociality), a burden for the community outside the church, and a desire for education in mission and witness. Weaknesses were a]so revealed--poor reproductive potential for new members, unmet felt needs especially among the young-married-age group, and a lower than desirable spiritual and devotional life in the church family.

\section{Personal Views of the Church Family}

In addition to information obtained through the surveys and that expressed in group discussions, I wanted to talk to members of the church family individually or in nuclear family couples. ${ }^{1}$ The aim was to learn how they felt about the church family, what they viewed as its strengths and weaknesses, and how the fellowship

${ }^{1} A$ condensed, lightly edited verbatim of the taped interviews is found in appendix $G$. 
community met or failed to meet their felt needs. Frequent visits and discussions familiarized me with the outlook of the few highly committed leaders in the church who carry the major burden of church operation. In the personal interviews, I especially wanted to hear from the members of the church family who were usually less outspoken, were more recent members, or were potential members. The philosophy found in the interviews is homespun and perhaps simplistic, the attitudes, judgments, and theology at times inaccurate, but it is a cross-section of how some of the members of the small 0tsego church look at themselves. From these totally subjective thoughts some major characteristics can be distilled which should give some indications of the present and future viability of the church.

One thing which seems to emerge is that some types of people with certain needs are drawn towards the small church. If the small church could recognize the drawing power it possesses it could capitalize more upon this ability in its growth profile toward the community.

Long time members

The needs of people vary greatly and the needs of new or prospective members are often different from "long-term" members. While examining what these needs are and how they are being fulfilled by this particular small church, we will look first at members who have been in the 0tsego church for at least five years.

Margaret has been an Adventist for most of her life. She attended the Kalamazoo church $\left(300^{+}\right)$for many years, but her twelve 
year old daughter wanted to transfer to the small otsego church when it was being reorganized in 1973. Reluctantly she left the larger church and with her daughter united with the Otsego church. Margaret says she still enjoys the friendly, close group at 0tsego. She says the influence of the minister has an important bearing upon the climate and attractiveness in a church, but feels it is the presence of friends and loved ones which is the biggest factor in the enjoyment of church fellowship.

Margaret is a very friendly, easy-going person and upon being asked by a friend if anyone could attend her church she replied that they certainly could. This friend has been attending quite regularly for about twelve months. Margaret is using her spiritual gift in a way which can help the church grow.

Carol, Margaret's daughter, is now twenty-one years old and is married to Dale, a ministerial student at Andrews University. She said she did not have very many friends in the Kalamazoo church, although she attended church school there, and felt attracted to the little church being re-established in 0tsego. She is not sorry she transferred there and enjoyed being the oldest of the "kids." It made her feel needed and wanted. She liked helping them with their problems and arranging functions and recreation for them. Carol indicated that at one stage, when passing through a low spiritual time in her life, the warmth of the church and the feeling of being needed by the younger children kept her in the church. Without this she probably would have left the Lord. Now that she is married and attending college, she and her husband Dale are members of another small church and enjoy the responsibilities and leadership placed 
upon them in another litile congregation.

Lloyd, with his wife Laura and two sons, has been attending Otsego since it was revitalized in 1973. Lloyd had grown up in a "small, small" church further west and liked the family fellowship as well as its close proximity of Otsego. They moved to Battle? Creek, where he was working, but continued to attend Otsego, twentyfive miles away, for a number of years. About twelve months ago the family transferred their membership to the large Battle Creek tabernacle situated close to their home. He indicated that one reason for the move was the cost of travel, but more important was the feeling that the larger church provided a more disciplined, informed, and structured environment for keeping his boys interested and involved-particularly, he suggested, in activities like Sabbath School. He admitted that there was some influences in the new, large church that concerned him--a greater number of uncommitted young people who could perhaps be an undesirable influence on the boys.

Lloyd points out that one problem in the small church is overburdening a group of leaders who find it impossible to adequately staff even the reduced number of departments in the small church. In this case he felt that the youth Sabbath School suffered from a lack of experienced, well-trained leaders and disciplined, informative programs. It was pointed out in chapter II that inadequate programs for the "internal growth" members of the church was probably the greatest operating problem of the small church. Only a deliberate, purposeful approach to the problem, with goals to meet this need given a high priority, would a solution begin to evolve.

Merv was a member of another denomination in otsego when he 
became convinced that he should join the Adventist faith and began to attend the 0tsego church. As he put it, he "fell absolutely in love with the people there." He married Wilma about four years ago and they attended the larger Kalamazoo church but were concerned that they felt lost and unrecognized in the large group, so they transferred to Otsego although it was much further away. They enjoy the family-style fellowship there and Merv has some leadership positions. Wilma has shown evidence of possessing the gift of evangelism and has been doing voluntary Bible work out of the church for the past two years. She feels happy about inviting her Bible study interests to worship services as she knows they will be fully accepted by the whole group and feel at home there. She expresses her reservations about the acceptance of such people in a large group which does not act as a family.

Merv and Wilma's experience points out a strong factor in the small church's personality--its ability to warmly welcome strangers by, as it were, throwing their arms around them and embracing them into the fellowship of the group. Such a climate forms a positive environment for newly reborn Christians.

Wilma's spiritual gift is already bringing souls into the church.

Visitors and new members

Louis is a fairly regular visitor to 0tsego from a moderately large "sma11" church about fifteen miles away. He feels that size does not always determine warmth in the congregation, but the large church has to work at it much more than the small congregation which 
seems to be able to show it more spontaneously.

He thinks that warmth must be radiated by many others in the congregation in addition to the welcoming committee at the door. Louis feels that less formality in the smaller church increases the level of "cheerfulness" and believes this is because more people are involved in leading out and operating the programs. In other words, people have more "cheer" because "everybody" has something to do--"busy people are happy people."

This interesting concept I had not considered before, but perhaps the small church is better structured to carry M.B.0.-type programs right out into the pews than is the big church. There is no doubt from the research that churches involve an increasing percentage of people in leadership and operating positions as size decreases. There also seems no doubt that people involved in running and planning within an organization have greater dedication and take a stronger interest in that organization, its growth, and development. Louis' home-spun philosophy may have hit on the fact that small churches should be closer to the ideal model of Management by Objectives than may be possible with larger organizations. Bonnie and Bill are also regular visitors from the same larger church as Louis. In fact they are attending every week and it is expected that they may soon transfer their membership to Otsego. Bonnie feels her children do better in a smaller church. Note the difference, though, with Lloyd--Bonnie's two children are about three and four years old and still closely attached to their parents, whereas Lloyd's are in their early teens and very attached to their peer group. 
Bonnie feels that with everyone having to work to operate the church it builds a spirit of team-work in the whole group. Bonnie feels that the message of the preacher is the most important element in the success of the worship service. It is not surprising that she, therefore, prefers the informality of the small church to the more structured program in a large church. Bill also notes the high involvement in working at keeping the small church operating and feels this is reflected in a stronger bond among the members.

Cliff, with his wife June, has been attending for about six months; he has been baptized recently and became a member of the otsego church. He felt attracted to the church by the welcome and the warmth of the people, as well as the conviction of the Bible truths he learned with Wilma's help. Cliff says he had never felt at home in a large church although ne saw little difference in the worship services. His wife June was in hospital expecting their first child and was unable to be present for this interview, she is preparing for baptism.

Chuck and Donna took Bible studies with Wilma and were baptized and joined the church about twelve months ago. They admit that they felt uncomfortable on the first visit to the worship service as it was obvious in such a small group that they were visitors. It was the personal contact and Bible study with two Adventist ladies that drew them into the church. They felt at home in the small congregation after the warm welcome and it was easier to attend each time after that. Cruck does wish for more activity in the church and finds the lack of other meetings such as prayer meeting and infrequent social activity a problem in the church. He wishes 
the pews were filled each Sabbath for he feels that when the people are spread out in the church it takes away a feeling of warm fellowship.

Donna likes the small church situation and feels that in worship services she feels closer to God in the simple, intimate service rather than the more complex worship in a large congregation. Socials, although not held as often as in a large church perhaps, make you feel closer to the people than in a very large group, she suggests.

These are just a cross-section of the ideas on fellowship given by the "ordinary" members of the small otsego church.'

My evaluation

In looking at the past history of this church it would seem that the church began with dedicated laypeople formed into a church congregation by wise pastoral leadership; however, it was layleadership which principally operated the church for over sixty years. Since then there has been an increasing burden placed upon an ordained pastor (shared with other congregations) to make major decisions in leadership. The records indicate a concern in early business meetings, prior to 1900, for lay-leadership visitation of the members--particularly those on the periphery or dilatory in worship atteridance. There is no indication of lay-visitation voted in the church after 1900 except for disciplinary and financial reasons. The business meetings of last century differed from those

$$
\text { I For a slightly condensed and lightly edited verbatim of }
$$
the taped interviews, see appendix $G$. 
which developed in this century. 'The quarterly Sabbath service was very special, including the ordinances if an ordained pastor was present, attendance reports, or apologies were expected from each member--those not reporting would be visited by a lay visitation team. Testimonies at this meeting were explicit, personal, and emotional--and were expected from a large number--particularly those wishing to join in membership. At the business meeting held the same night or the next day, discipline was firm and not long delayed--for non-attendance and/or non-reporting, apostasy, etc. Transfers of membership, in or out, were not voted by rote but long pondered and often rejected. The overall impression is given that the activities of the church were the most important element in these people's lives, and they took church doctrines, standards, and relationships in the utmost seriousness, believing they had a real bearing upon their own salvation.

Increasingly through the twentieth century this "seriousness" in the business of the church lessened. Perhaps in some ways it was for the better, in others it may have made the church weak and ineffective. The business meetings indicated by the clerk recorded more and more financial matters and less personal material. Public evangelistic campaigns have evidently never been a frequent event in Otsego--averaging one every fifteen to twenty years, although those prior to 1900 were probably the most influential of all in building membership during that early period.

${ }^{1}$ Although at least as recent as June 18,1927 , testimonies were still being made, at this meeting thirty-six people gave testimonies well over half of the then seventy members! 
Since the church reopened in 1973 there has been help from Seminary students. Consequently, some dependence upon them in addition to that already placed upon the pastor, has developed. It is doubtful if the church could exist today under almost total layleadership as it did through the late 1800s. Leadership, mission, and witness training need to continue so that this aspect could be strengthened from the present low confidence in their own layleadership ability.

The viability project centered around a congregational survey which revealed certain strengths and weaknesses in the church. Firstly, the church membership liked the warm fellowship present in the group and most felt it met their own personal needs fairly well; their grasp of some current issues on beliefs was quite good--they are evidently not cut-off from developments in the Adventist church as a whole and reflect the same indecisiveness on some issues as the church at large. On the other hand, a large number showed no desire to have Bible studies with others, although a little under half of the tested group indicated some activity in witnessing and actually placed witnessing as the highest priority of a Christian. In the survey, and later in Hout's questionnaire, the gifts of the Spirit as indicated in the church, majored in the area of personal relations--helps, hospitality, faith, mercy, service, etc. Only one indicated the gift of administrator, one of teacher, and two for evangelist. Over all, leadership-type gifts were hardly represented at all, and a number of people had quite low over-all scores on the Hout's questionnaire.

In applying the results to Reichert's eight family 
functions, ${ }^{1}$ my subjective evaluation would indicate the church quite strong in its Protective, Nurturant, and Socialization functions. The people feel secure with their pastoral leadership, their channels for counseling and comfort, and their social relationships together as well as with those outside the church society. Their spiritual and devotional function (Philosophical) seems below an acceptable level and it would seem that other things have squeezed this out of primary importance. From all indications in the records, this same church in the nineteenth century ranked high in this area. Also their Personalization function seems slightly depressed, perhaps indicating not enough action or opportunity for engaging in the development of personal gifts and talents within the church. They show a need for education (particularly in the area of mission and witness) and a concentration upon elevating their Reproductive function. The latter may be best accomplished by further training so that witness is seen. as much broader than having formal Bible studies with people and knocking on strangers' doors. The section on witness showed a good response to the attitude and theory of witness--so there seems to be a good mission foundation to build upon and develop.

In comparing the survey results with Mayer's five Christian actions or graces, it would seem that the public worship action is adequate (within the informal structure of the small church), but the private expression of this (personal devotion, witness, and functions.

ISee chapter II and table 7 for the various suggestions on 
study) is less than adequate. Fellowship is high, but in relationship with other small churches actual comparisons are unknown. Witness is being engaged in to a limited extent and a few members are showing good, tangible results, but the concept seems to be well grasped by the respondents. Service is limited, but the need is recognized and moves are being made (largely centering in preparing the adjoining building for an "open house" in public welfare programs) to put plans into action. Nurture seems adequate in the church, with considerable informal lay-visitation and encouragement of members aided by pastoral visitation. The results are similar when applied to MacNair's four viability functions: worship, growth in grace, outreach, acts of mercy.

To this must be added the constructive suggestions and viewpoints gained from the open-ended questions, which indicated a deep interest and concern for the success of the church in the town and a particular desire to further develop the present good level of koinonia in the congregation.

The goal-setting meeting held after the survey was well attended and the group activity included at that time highly involved those present. But, true to the characteristics of a small church, the development and feeding of personal relations was perhaps more important to them than the plans and goals developed in the meeting. This must be accepted as normal with a small church, and strong drives to task accomplishment might only frustrate and slow up the church in its operation. The action strategies formulated at the meeting were not all carried out, and the most important one, the completion of the adjoining house, still has not been accomplished, 
due to unseen circumstances. The education program initiated at this meeting ran for six months with fluctuating attendances. This involved two sections: the first dealing with Spiritual Gifts and the second, a Bible-marking seminar. A third series on witness within the Otsego Community is planned for the near future.

Finally, in evaluating the personal responses of individual church members to questions about small churches, and their 0tsego church in particular, the following things could be said. ${ }^{1}$ (1) Their responses seemed to support other studies that small churches draw people of a certain "pro-family style group" outlook--they need to worship in this type of situation. They are people who usually do not mind being involved in leading out in some area or another; they are people who like being put to use. Margaret, Chuck, and possibly Donna may not be "smal1-church oriented" peop?e. Margaret, because of her nature, may fit into any size group quite comfortably, wherever she had friends. It would seem that the needs of the teenagers and young marriedsare least we 11 catered for in this church and with their church orientation not yet firmly determined this group is the one most likely to seek a different church setting. Carol seems to be one who had a "smal1-church orientation" from her childhood days and found the 0tsego church a supportive fellowship for this. The sma11-church characteristic of "people before programs" seemed to be also borne out in the interviews, with the recognition of a higher involvement percentage-wise of members in leadership positions--some saw this as building a team spirit and perhaps unknowingly voicing

\footnotetext{
${ }^{1}$ See appendix $G$.
} 
the strangest tenet of Management by Objectives--participation builds interest and involvement.

Certain weaknesses of the small church were voiced--inadequate programs, particularly for the young, and inexperienced and ill-trained leadership in some departments. Little involvement in the community outside the church was also seen as a weakness.

The Otsego church is a viable group but is unlikely to grow much beyond the fifty-membership level unless there is a radical change in the present outlook of the people or a large influx of different folk--both eventualities not very likely in the near future. Much will depend on encouragement and support being given to the lady Bible worker who has been foremost in developing this growth. Her manner and approach is very good and the results encouraging. Possibly one or two others may be able to be trained to do similar work, but the rest may have to learn how to employ their different gifts more effectively in other ways in the broad work of mission and witness.

One problem in the church seems to be the increasing dependence upon the leadership of the pastor--voiced in the survey as the greatest need being that of a sole pastor for the church. The desire does not seem to be a completely healthy one, although the sentiment for it is understandable and reflects the trend of the past fifty years. Such a request is unlikely to be granted in the near future and wishful thinking may hold the church back from making positive steps toward increasing their size and their viability themselves. 
CHAPTER $V$

THE CHURCH AS FAMILY--CONCLUSIONS

AND SUGGESTIONS

\section{Implications from Theology and Scripture}

From a basis in the doctrine of the Trinity, family-style love and interaction can be postulated as a model for the church, because through reconciliation, redeemed humanity has been offered a place within the family of God. The death of the elder Brother has meant the full adoption of His brothers and sisters into the kingdom family. The way this best seems to be expressed in this non-glorified earthly existence is within the fellowship circle of a one-cel1, primary group, worshiping community. Within such a group, koinonia seems best able to be experienced and expressed, but it also must be extended through the open doors of the church into the society of the world outside.

Under the metaphor of family-style images, the NT speaks of the sons and daughters of God and indicates how these children should live and act within the household of love. The scripture's presentation of the family imagery seems to be that of a community breathing the atmosphere of loving fellowship. The children reflect the perfection of the Father in loving others as He does. They should be ever mindful that there are no natural earthly children in this family, except the Son, and hence they are children by adoption-- 
which grants them an equal place in the kingdom with all other beings in God's creation. In being adopted into the family and called out of the world, they are also sent back into the world to identify and mingle with it so that they might be God's agents of reconciliation to mankind. The scripture's picture of an ideal, loving household bathed in koinonia seems best expressed in a small-group, familytype congregation.

Not only does the NT present the theory and ideal of what the Christian community should be, it also describes the actual churches which grew up founded upon the teachings of Jesus and the disciples. From all the evidence available it appears that smallgroup house-churches formed the basis of the worshiping communities. It also seems that the very factors spoken of by Jesus and the disciples were the foremost characteristics of the apostolic churches. There appeared to be no hierarchy in the apostolic communities, although strong leadership seems apparent. The independent housechurches would have been strongly resistent to hierarchical development and yet there seemed to be a surprising oneness, a unity, in the Christianity which spread through the Roman Empire. The Christian churches did not withdraw from their most fruitful mission field--the Jewish synagogues and communities, rather they remained closely allied with or even remained within Jewish society. It seems that they continued worshiping in the Jewish synagogues until Jewish persecution drove them out. Yet the churches of the apostolic era developed into churches with doors open to all the world. Under the ministry of Paut, racial distinctions or divisions within Christian churches began to be broken down as congregations saw their 
mission addressed to all mankind regardless of color, race, sex, or nationality.

It appears that the small house-churches of the apostolic era faithfully exemplified and practiced the theory and guidelines expressed in the teachings of Jesus and the apostles.

\section{Implications from the Relevant \\ Studies and Literature}

Personal relations are the most important characteristic of the small church. In fact, by nature, small congregations normally consider these before such task orientation as goal-setting, etc. Hence, in suggesting planning procedures for the small church, personal, "family" relations should always be taken into account. Fellowship seems to be the "glue" which binds primary groups, like small churches, into one unit. This "glue" appears to run out above the 200 to 250 membership point suggested by a number of authors, so probably groups above this size should not be classified as small churches.

Small churches seem to show different levels of success in meeting the needs of the various age groups within the congregation. Many small churches have not grown very much, or at all, over a long period because they are primarily composed of older folk who have their needs well met in a typical small church. The accent upon the past and the low level of activity, both characteristic of small churches, are features of late and post-middle age people. The needs of prospective new members in the unbelieving community are either not met by the believers in the small church or are not seen to be met by those outside the church. Outreach work by the small 
church, therefore, is often met with little success, if it is attempted at all. Yet the family fellowship present in a small church can be a powerful instrument to win souls, for there are many lonely, homeless people looking for a warm fellowship community to provide a surrogate family.

If small churches can evaluate their talents and gifts, and open their doors to the world outside and let the fellowship love of a reconciled community flow out, many more people would be impressed by the witness of the church and drawn into its fellowship. Exclusivism and introversion must be overcome by genuine koinonia so that all who wish to fellowship with the group--whatever their background, color, race, religion, or sex--are warmly welcomed and accepted as souls whom the Lord loves and whom they should love also.

A number of studies conducted since the late 1960s seems to indicate certain advantages in the small church when compared with large institutions: (1) they seem better able to assimilate new members (Wicker); (2) they have a higher percentage of the roll membership in regular attendance at worship services (Wicker, Wilkien); in Adventist church circles (3) they appear to have a higher per member giving level--particularly in mission offerings (Scofield); (4) they seem to show a higher religious commitment level (0osterwal); and (5) they exhibit a lower apostasy rate (0osterwal).

In church "kingdom" growth, (i.e., growth patterns exclusive of transfers) the results seem to be more on a curve than lineal, with very small churches (below fifty) at a serious disadvantage showing the highest percentage of churches with zero growth (56.1 
percent). ${ }^{1}$ This latter study indicated results somewhat different from Dosterwal's more limited survey in that it had churches above five hundred members having the highest percentage of churches (90 percent) with some growth and an about average growth percentage of 5.4 percent. Table 9 indicates that per 1,000 church members, churches below 150 have the highest growth rate, but evidently transfers in some small churches are placing them into the nongrowth section. ${ }^{2}$ Up to the five-hundred level the curve for growth in the initial NADCG study generally confirms Dosterwal's findings and seems to indicate a church size in the range of one-hundred to three-hundred members as being optimum for growth--this is still in the range of the small church, but while keeping the advantage of a one-cell family it is also large enough to meet the needs of the members and the worldly community outside. Very small churches (below fifty) may not expect to see a radical change in their growth patterns, unless the milieu in which they are placed changes. ${ }^{4}$ For many this will not be likely, so they should evaluate themselves and their potential; and constantly monitor their communities, looking for people and areas with the greatest potential for growth. If and when the society changes to a more favorable one, the church should be immediately aware of it and make aggressive plans, within their

1 See tables 3 and 8. NAD Church Growth Study.

${ }^{2}$ Compare tables 8 and $9 . \quad 3$ See figs. 1 and 2.

${ }^{4}$ It would appear that some amongst the third of growing churches below fifty could be drawing transfer membership from 151200 and over 500 membership churches, this perhaps should be further investigated. 
183

TABLE 8

KINGDOM GROWTH PER 1000 CHURCH MEMBERS

\begin{tabular}{lccc}
\hline $\begin{array}{c}\text { Size of } \\
\text { Church }\end{array}$ & $\begin{array}{c}\text { No. of Members } \\
\text { in Churches with } \\
\text { some Kingdom } \\
\text { Growth }\end{array}$ & $\begin{array}{c}\text { Average } \% \\
\text { of Kingdom } \\
\text { Growth }\end{array}$ & $\begin{array}{c}\text { No. of New } \\
\text { Kingdom } \\
\text { Members }\end{array}$ \\
\hline $1-50$ & 438 & 4.4 & 19.3 \\
$51-100$ & 650 & 6.6 & 42.9 \\
$101-150$ & 826 & 6.2 & 51.2 \\
$151-200$ & 857 & 5.5 & 47.1 \\
$201-300$ & 824 & 3.7 & 30.5 \\
$301-400$ & 800 & 2.8 & 22.4 \\
$401-500$ & 667 & 3.8 & 25.4 \\
$501-$ & 900 & 5.4 & 48.6 \\
Average & 658 & 5.3 &
\end{tabular}

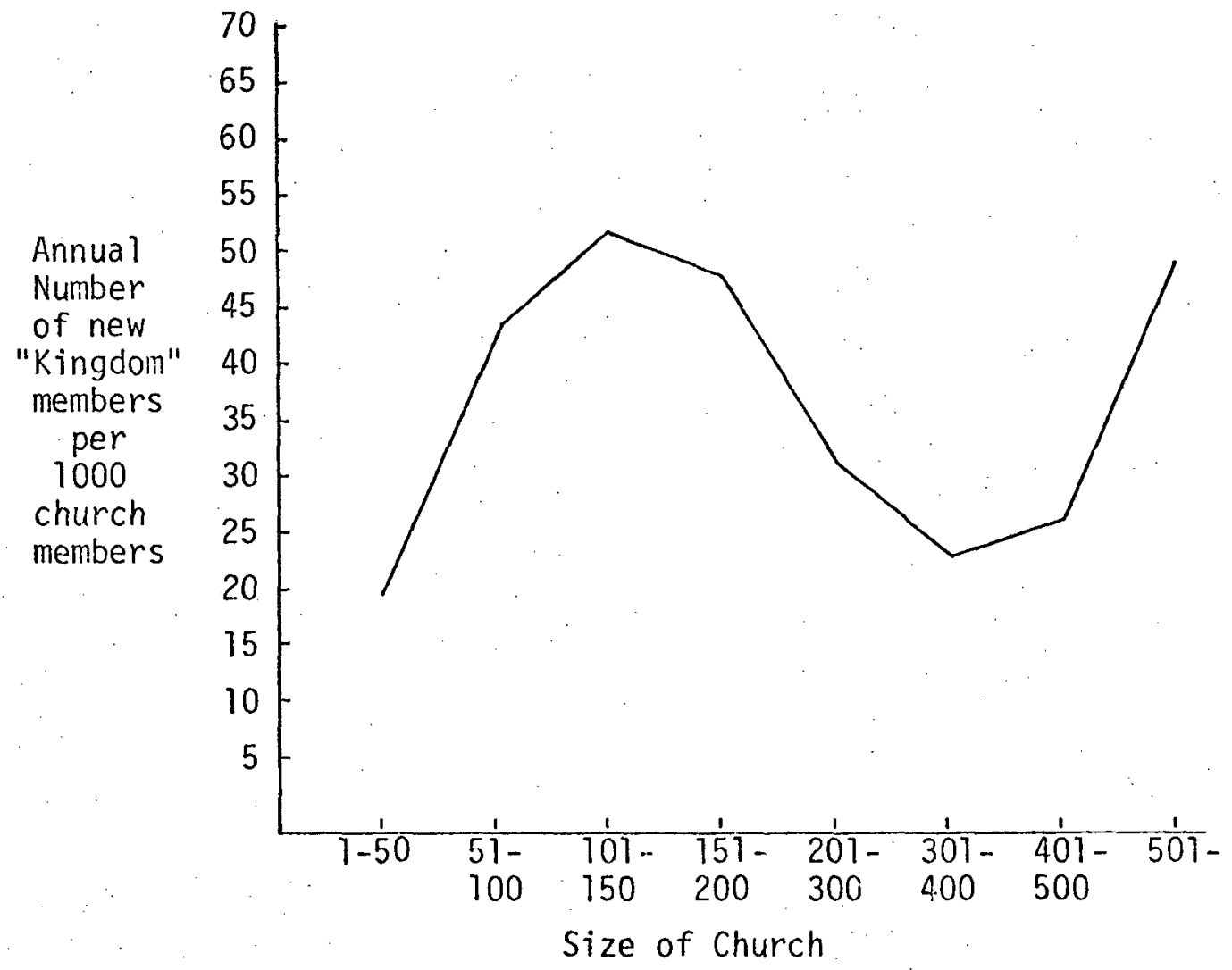

Fig. 1. Church Size to New Kingdom Members from Above Table, in Graph Form. 
TABLE 9

CHURCH GROWTH PER 1000 CHURCH MEMBERS

\begin{tabular}{lccc}
\hline $\begin{array}{l}\text { Size of } \\
\text { Church }\end{array}$ & $\begin{array}{c}\text { No. of Members } \\
\text { in Growing } \\
\text { Churches }\end{array}$ & $\begin{array}{c}\text { Average } \% \\
\text { of Growth }\end{array}$ & $\begin{array}{c}\text { No. of New } \\
\text { Members }\end{array}$ \\
\hline $1-50$ & 333 & 10.6 & 35.3 \\
$51-100$ & 633 & 6.4 & 40.5 \\
$101-150$ & 739 & 6.8 & 50.3 \\
$151-200$ & 643 & 1.6 & 10.3 \\
$201-300$ & 824 & 3.9 & 32.7 \\
$301-400$ & 600 & 2.7 & 16.2 \\
$401-500$ & 667 & 3.0 & 20.0 \\
$501-$ & $\underline{727}$ & $\underline{2.4}$ & 17.5 \\
Average & 580 & 6.7 &
\end{tabular}

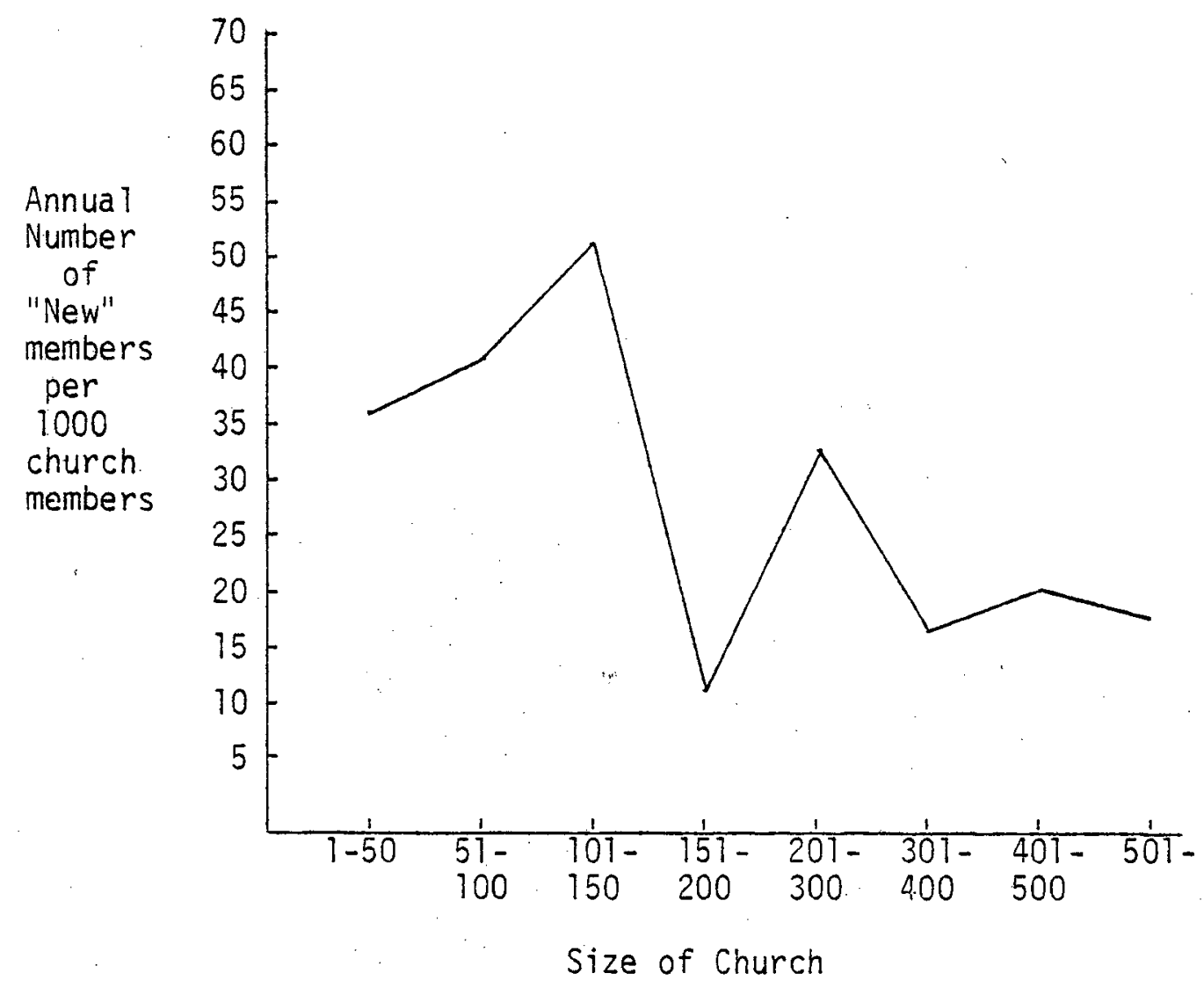

Fig. 2. Church Size to "New" Members from Above Table in Graph Form. 
capacity and under the blessing of the Holy Spirit, to work in this newly developed, more fertile soil.

\section{Implications from the Otsego Situation}

The history of the otsego church indicates that this congregation is a very typical small church. It grew slowly until 1900, then rapidly to 1918, dipped rapidly, flattened out, and then slowly declined. After its "resurrection" it grew to fifty-two in 1975, declined to thirty-four in 1978, and has inched upward to thirty-six at the present time (1980). The membership figures of over onehundred in the early 1900s were quite artificial and the sole result of Otsego becoming a temporary Adventist institution church. Many of the members who came and went in that period were not really committed to the church or the town, they were committed to the organization and when it moved, the church returned to a typical smalltown congregation. The same was again true to a lesser extent after the revival in 1973. A considerable number of people who assisted in re-establishing the church and joined at that time were not really committed to the church or the town, they were committed to an idea and a project--to re-establish a defunct historical church. The same is true to a certain extent of ministers and seminary students with membership there, including my wife and myself. It is the lay-members who ultimately will decide the fate of this church-and probably most churches large and smal1--for they are the ones who are committed to the church and the town.

It would seem that there is reasonable conmitment in Otsego to the church and town, but many members come fairly long distances 
to the church and since other churches are just as close, the commitment cannot be said to be very high in strength. If the energy crisis worsens, more may choose to attend closer churches and forsake 0tsego, though its current high family-fellowship and communal love may prove stronger than high priced gasoline.

The Otsego church reveals the expected characteristics of a small church--positive ones of high warmth and fellowship, involved worshipers and, quick decision making; and negative ones of slow growth, fragile goal-accomplishment power, and a drain to institutional churches. This membership drain is discouraging but it is all too cormon--according to the initial NADCG study, 43.8 percent of churches below fifty had some "kingdom" growth, but when transfers were taken into account, their overall growth dropped to only 33.3 percent of these very small churches having any growth. ${ }^{1}$ one third of small churches are growing and otsego appears to be in this category at the moment, but it must bear some of the responsibility for its losses. Needs not being met cause members to move to churches where they are met. Otsego needs to shift more of its emphasis from meeting needs of the over-fifty year olds to those of families with children--for this group holds the immediate destiny of the church. Death continues to reduce the membership at an increasing rate as the average age of a long stagnant small church continues to rise, but transfers out of the church could be reduced, and possibly the lesser problem of apostasy as well, by a re-appraisal of potential and priorities in the church.

${ }^{1}$ Compare tables 2 and $3 ; 8$ and 9. 
The survey and project in the otsego church revealed it to be in reasonably healthy condition, but it has weak reproductive power, hence its viability is somewhat marginal. The spirituality of the church seems lower than it should be but is probably average. $^{l}$ The accessions into church membership recently are gratifying and, if maintained together with other changes, slow church growth could continue. The process of goal setting, planning, and lay-witness training needs to be continued and this should broaden the spiritual gift utilization and reproductive base in the church.

\section{Suggestions for the Future}

Sma11 Church Education

When the results of surveys such as the Church Growth (now in progress) become available, small churches should see the results and their implications. If their own pastor is unable to do this, trained men need to be brought in to do it. There is much available in studies and scholarly literature to support the small church institution. The members of small churches should know their value, for most of them live under a constant inferiority complex--most of which is unwarranted. Training to recognize, develop, and use its spiritual gifts is important if not essential to small churches. But of equal importance is a recognition of the needs of the various age, social, and interest groups within the church. Priority should be given to the most crucial ones for reproduction--to the youth and young marrieds.

Study should be made of needs in the outside community and

${ }^{1}$ See the Philosophical function score in table 7. 
plans, within the limited resources of the small congregation, should be made to meet these. The church should be educated to search out and recognize social needs, for the Adventist church has tremendous resources for this purpose--even when channelled through a small church.

Relationship with the Organization

The climate seems to be improving for a more fruitful interaction between organization administration and the small church. As administrators recognize the potential of the koinonia present in the healthy small church to help that church grow, an added respect should be engendered in relationships. The results should be conference organized training seminars in small-church growth and enlightenment in the dynamics of the small church so they can better understand and appreciate themselves.

If FAA is successfulity implemented in North America, then the mutual respect of the local church for the conference, and vice versa, should be improved as goal setting is put back into the local congregation. This will require much training at all levels, including the local church itself, and my fear is that this training may not be adequate to convince and "convert" leaders and administrators and may not be well enough grasped by the laity to successfully implement it.

Inplications of Radical Reconstruction

A small church which accepts the fact that its koinonia is also for the world, that it must be extended beyond the front door of the church into the community, and then goes ahead and does 
it, must also expect some drastic results. They must be willing to welcome and embrace those who choose to fellowship with the smallchurch people, those who may be of a different color, a different financial and social group, and sometimes with a sordid or notorious past. But when these people enter the front door of the small church they must find an incubator room inside and not a freezer. If the small church cannot come to this place under the grace of God, then it has not yet grasped koinonia and probably as a group has not yet grasped the hand of the Master. They cannot grow. The foremost contemporary writers in ecclesiology are saying that the Christian church of the future will be a church at grass-roots level, one made up of people in primal communities or family-fellowship groups. The trend is well under way in Europe and there is every indication that it will grow here in the United States as well.

If a church evaluates itself as too small to continue operation, it should seriously consider the options. Closing the church is a traumatic event, but it may be a better choice than continuation with a few people (often the young) whose needs are grossly unmet. If members can fellowship in another small church which fully adopts them, the psychological trauma can be reduced, but if they are forced to attend a large church the effect upon the small-church member can be severe. Equally traumatic seems the apparently easy solution of amalgamating two small churches to make a bigger and better whole. I have done no objective studies in this area and more needs to be done on amalgamating beyond the studies by licker. It would seem from my experience and from personal interviews that the end result may be worse than the two individual small churches. Transplanting 
living organisms, like small churches, is a delicate, risky business and should be approached with great caution and investigation.

Another alternative, which seems to have met with greater success, is for small churches to recognize that they cannot hope to meet all the needs of some groups and to cooperate with other small churches for certain social events, mission projects, schooling, etc. This is better than just ignoring the needs of certain groups, even if it takes time and effort to build relationships in the combined activity group. Cooperation does not destroy the individual small churches. These continue, especially as Sabbath morning worshiping fellowships. It means that all the strength can be thrown into operating just Sabbath School and the worship service. Because of the strong individualism of small churches, even this solution may not always work in practice. A "big sister" role by a fairly distant large church could supply some leaders and programs a small church needs for the few youth and children in the small church. Such would be a worthy project for young people in the larger church. Radical reconstruction within the small church to increase its viability could result in operating structures that are more in line with its natural characteristics. Hence the small church may. operate without a board and solely through a regular (say bi-monthly) business meeting. It may have to eliminate department leaders, but should not if it can be avoided. If anything, the small church should try to maintain regular reporting at business meetings by the leaders to encourage them in their work, but it may be done better in the informal setting of a testimony meeting. The 0tsego church members are not reluctant to give testimonies and the informal 
atmosphere of small churches encourages such. Regular opportunity for this should be made and it could be incorporated with a more devotional program in the regular business meetings. A return to a nineteenth-century style of business meeting, at least in some things, would seem to fit the personality of the modern small church admirably.

There is no reason why organized lay-leadership visitation cannot be done in a small church, as is done in large congregations. While the effect may not be so dramatic, it will nevertheless be beneficial.

None of these suggestions are really "radical" but any change at all in a semi-fossilized small church could be classified as radical. Some small churches are going to have to honestly evaluate themselves and change or the increasing death rate will finally exterminate them.

\section{The Future of the Small Church}

There is no indication that the small church will die out as an institution, rather it seems that it will have an increasingly important role in the future development of Christianity--particularly within the Seventh-day Adventist church. It above all church institutions has the greatest potential to effect a proper balance. and interwoven relationship between kerygma, diakonia, and koinonia, and then to present that threefold unity to a searching world. It may be limited in meeting the needs in the surrounding community, but by its inherent nature of being people oriented instead of things-or-task oriented it has the capacity to reach the very heart 
of searching souls. It can provide a community whereby people can feel at home, unthreatened and accepted. As Schumacher said, ". . people can be themselves only in small comprehensible groups."

Or as Moltmann, the theologian with whom we began this paper, asked,

What would it be like if Christian congregations and communities were no longer to regard themselves only as "the community of saints," or as "the congregation of the faithful," but as such a "community of friends?" . . . Then they would have to break through their unconscious and sometimes, unfortunately, also very, deliberate exclusivity with respect to the "evil world" and "unbel ievers," and be ready for friendship with the friendless. Then they would have to assemble in grass root communities that would live close to the people and with the people in the friendship of Jesus. ${ }^{2}$

It would seem that small churches may be best able to fulfil the suggested future role for Christian communities. But not only will small churches have to re-examine themselves so that they may better develop and carry koinonia into the world outside, large churches may have a greater moral responsibility to do so as well. It may not be sufficient to perpetuate large churches on the grounds that some people need to be buried in a large crowd at worship, ${ }^{3}$ or that the small-group cells and sub-congregations do as well in koinonia as individual small churches. The evidence seems to indicate that if a one-thousand-member church in a large city broke into five, scattered, two-hundred-member separate congregations it would provide better koinonia amongst the members than any

IE. F. Schumacher, Small Is Beautiful (New York: Harper and Row Publishers, 1973), p. 70 .

2 Moltmann, The Open Church, p. 62.

${ }^{3}$ E.g., like C. Peter Wagner a confessed big church person, Your Church Can Grow, pp. 97-108. 
sub-congregations could accomplish, and also make a much greater missionary impact upon that community. Yet such a radical division could be as traumatic upon big-church-oriented people as absorption of a small church by a large church makes upon small-church folk. Perhaps in the future, honest dedicated Christians in some large churches will take this radical step and out of it find a new world in the small church.

\section{Conclusion}

This study would seem to indicate that for an organization to truly be the church in the world then kerygma, diakonia, and koinonia needs to be present and experienced in a balanced combination in the total life of the berieving community. Hence an emphasis should be placed upon a rebuilding of koinonia which seems to have become weakened (and with it an unfortunate concurrent weakening of both kerygma and diakonia, for the three are tied inextricably together). It is suggested that a return to family style communities could accomplish this in the best way. But if a truly strong koinonia (and with it kerygma and diakonia) is to be established there must be a proper balance between loving family fellowship--a "glue" which seems to generally grow stronger as the group gets smaller, and the fulfillment of the needs of the local church (also an intimate part of koinonia), which seems to get weaker as the group gets smaller.

In general terms it seems this balance between fellowship "glue" and need fulfillments balances out best in churches of 100 to 200 membership size. Factors such as proximity of other churches, 
community pecularities, and educational facilities, may modify this proposal but as a "rule of thumb" in the North American situation, such a size would seem to be optimum. For large churches wishing to spawn and smaller churches looking for an optimum size to aim for, such a 100-200 membership size proposal may be helpful.

Small churches should see themselves as a legitimate section of the "church," maybe the legitimate section, with a leaning on the strength of the Lord for the support which they so desperately see lacking in themselves. Through them the "family" might teach love and reconciliation:

Family is the last holdout of the non-utilitarian mode. It will not allow you to make it into a commodity. It must teach the church its living word so that the church can teach the world how life is generated, how faith is shared, and how God is love.?

IRichard Rohr, "Building Family," Sojourners $\&$ (January 1979): 22 . 
APPENDIX A

CONGREGATIONAL MEMBERSHIP SIZE TO NUMBER

OF CHURCHES IN DENOMINATION 
CONGREGATIONAL MEMBERSHIP SIZE TO NUMBER OF CHURCHES IN DENOMINATION

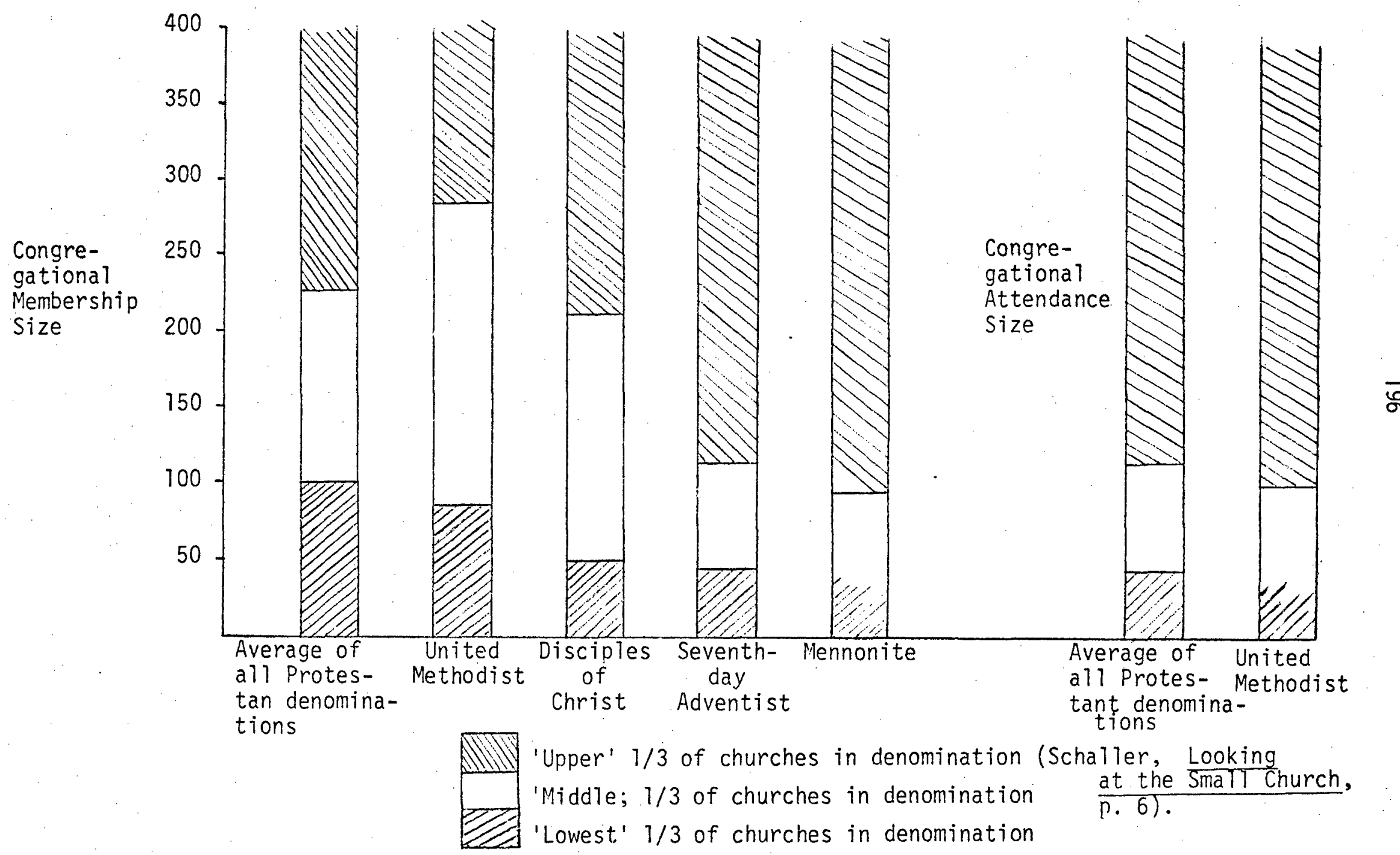


APPENDIX B

EARLY CHURCH CONGREGATIONAL SIZE AND PASTOR-LAY IMPORTANCE 


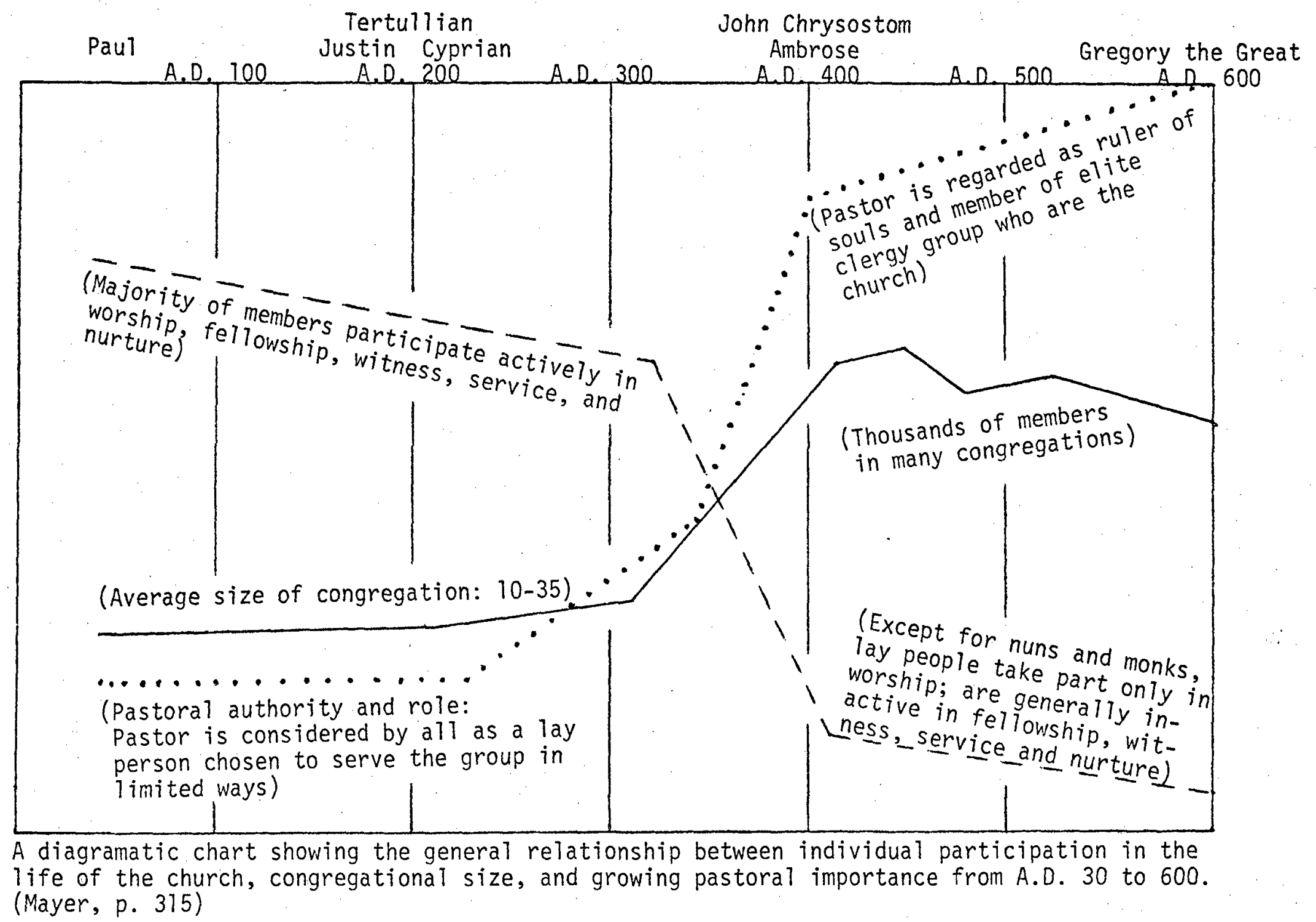




\section{APPENDIX C}

RELEVANT PORTION OF OTSEGO CHURCH BOARD-MEETING HELD TUESDAY, APRIL 22, 1979 
APPENDIX C

\section{RELEVANT PORTION OF OTSEGO CHURCH BOARD-MEETING HELD TUESDAY, APRIL 22, 1979}

Pastor Carl: Brother Hortop has something he would like to present to the Board.

Kerry (researcher): (Presents his suggested viability project, with surveys, goal setting meeting, etc., emphasizing that he would operate it under Pastor Carl's leadership and that any planning for the future would lie with the church itself. Some favorable characteristics of the church, providing a basis for the project, 'were dwelt upon, plus the fact that the project design was such that no individuals or families in the church would be alienated. The role of Spiritual Gifts and assessment of potential and possibilities for the congregation were presented to the board, together with some tangible suggestions for growth in church influence in the community.)

Pete (senior elder): You mentioned growth--what do you mean by growth--just an increase in members? You see, in the past we have regularly brought folk into the church, only to see families and individuals move out into other areas and churches and our numbers end up back where they were before. What about the development we are putting in here physically, with the Shepard house and all?

Kerry: The growth I would be looking at is a broad concept--embracing organic, spiritual, physical--everything that goes to make us up as a church. So, yes, we will be assessing growth, or the lack of it, in membership and also other areas--including the physical plant, so that development of the Shepard house would be included.

Pastor Carl: We were just talking about the possibility of some sort of public evangelistic campaign this coming church year, how would this or similar schemes fit in with this program?

Kerry: I believe it would fit in very well, and from the viability appraisal meeting, goals could be set which would include such a campaign or similar plans to be instituted during the year.

Pete: You would need to have some way of measuring whether we were growing or not, or what we were doing--how do you plan to do that?

Kerry: In a few weeks time I plan to give the church a fairly comprehensive survey which should give us a profile of the church's current attitude to ministry and mission, social and community, 
some beliefs, and mission. We have already taken a survey of the members' standing on items of physical health. Then we will hold a meeting to look at our viability and from that set goals for the church--particularly over the next twelve months, to see what we can do and where we can go with what potential we have.

Pat (senior deaconess): It sounds interesting, I would like to see if we could grow.

Kerry: I believe when Tom Ludowici was here he held some meetings on the subject of Spiritual Gifts. I would like to find out what you did then and work on from there.

Pete and Lloyd (deacon) indicate that they attended this seminar on Spiritual Gifts, but gave no details of it at this meeting.

Wilma (Sabbath School teacher, Bible-worker): Well, I would like to know what Spiritual gifts I had. I will look forward to that meeting.

Kerry: Well, we can look again at Spiritual Gifts, for there must be quite a number who didn't go through the last seminar. We will aim to show how the various gifts can be put to work to help the church grow. There is a new climate in the church whereby it is recognized that not everyone can be expected to do equally well what another brother or sister gifted in that area can do.

Meeting then moved on to other business. 
APPENDIX D

QUESTIONNAIRE 
APPENDIX D

QUESTIONNAIRE

You can greatly assist your Pastor in his ministry to the needs of the Church and the community. Please give careful thought as you answer each of the questions asked. Your forthright answers will be greatly valued and kept in complete confidence. Thank you so much! Your Pastor.

NAME OCCUPATION

ADDRESS ADDRESS OF OCCUPATION

(zip) (zip)

HOME PHONE BUSINESS PHONE

CONTACT IN CASE OF EMERGENCY

CURRENT CHURCH OFFICE/RESPONSIBILITY.

FORMER CHURCH OFFICES/RESPONSIBILITIES

DO YOU PLAY A MUSICAL INSTRUMENT? WHAT IS IT?

DO YOU ENJOY SINGING SOLOS, IN DUETS, TRIOS, QUARTETS, ETC?

IF SO, DO YOU SING BASS, BARITONE, TENOR, ALTO, SOPRANO (circle one)? KINDLY LIST THOSE IN THE CHURCH WHO YOU KNOW PLAY A MUSICAL INSTRU$\operatorname{MENT}(S)$, OR SING

DATE OF BIRTH (Please)

DATE OF BAPTISM WHO BAPTIZED YOU?

WHERE WERE YOU BAPTIZED

WHAT WERE THE GREATEST FACTOR(S) INFLUENCING YOUR DECISION TO BE BAPTIZED?

ARE ALL MEMBERS OF YOUR FAMILY ADVENTISTS?

PLEASE LIST NAMES (AND ADDRESSES AS BEST YOU CAN) OF THOSE NOT YET BAPTIZED, AND/OR THOSE WHO HAVE BACKSLIDDEN

(1ist others on back side) 
IF I KNEW MY RELATIVE(S)/FRIENDS WHO ARE NOT NOW MEMBERS OF GOD'S REMNANT CHURCH COULD HEAR ONLY ONE MORE SERMON BEFORE THEIR DEATH, I WOULD WANT THEM TO HEAR MOST OF ALL ABOUT

IF I KNEW I WOULD HEAR ONLY ONE MORE SERMON BEFORE MY DEATH, I WOULD WANT TO HEAR MOST OF ALL ABOUT

OUR CHURCH NEEDS MORE SERMONS ON (select up to 10 only, please):

SALVATION BY FAITH

CHRISTIAN UNITY

FORGIVENESS

STANDARDS

SABBATH OBSERVANCE

THE GREAT PROPHECIES

SANCTUARY

JUDGMENT

SECOND COMING

SPIRIT OF PROPHECY

LAW

GRACE

PRIORITIES IN LIFE

HOW TO OVERCOME TEMPTATION

HOW TO OVERCOME FEAR

HOW TO ACCEPT YOURSELF

CRITICISM

CHRISTIAN LOVE

FAMILY RELATIONS
THE CHARACTER OF GOD WHY HUMAN SUFFERING WITNESSING REARING CHILDREN CHRISTIAN EDUCATION. HEALTH HOLDING GRUDGES HOW TO BE PATIENT REPENTANCE RELIEVING GUILT MEANING OF BAPTISM CONDITION IN DEATH SPIRITISM PURPOSE IN TRIALS WITNESSING REVERENCE STENARDSHIP (other) (other)

THE GREATEST NEED OF OUR LOCAL CHURCH IS

"IF I WAS PASTOR OF THIS CHURCH, ONE THING I'D NEVER NEGLECT TO DO WOULD BE:" 


\section{5}

HOW LONG SINCE YOU HEARD A SEPMON ON (check under appropriate columns) One Month Three Months Six Months One Year Never HEALTHFUL LIVING STANDARDS

SALVATION BY FAITH SIGNS OF 2nd COMING SABBATH OBSERVANCE LABOR UNIONS RELIGIOUS LIBERTY CHRISTIAN EDUCATION SPIRIT OF PROPHECY SITUATION ETHICS THE GREAT PROPHECIES SPEAKING IN TONGUES WITNESSING FORGIVENESS

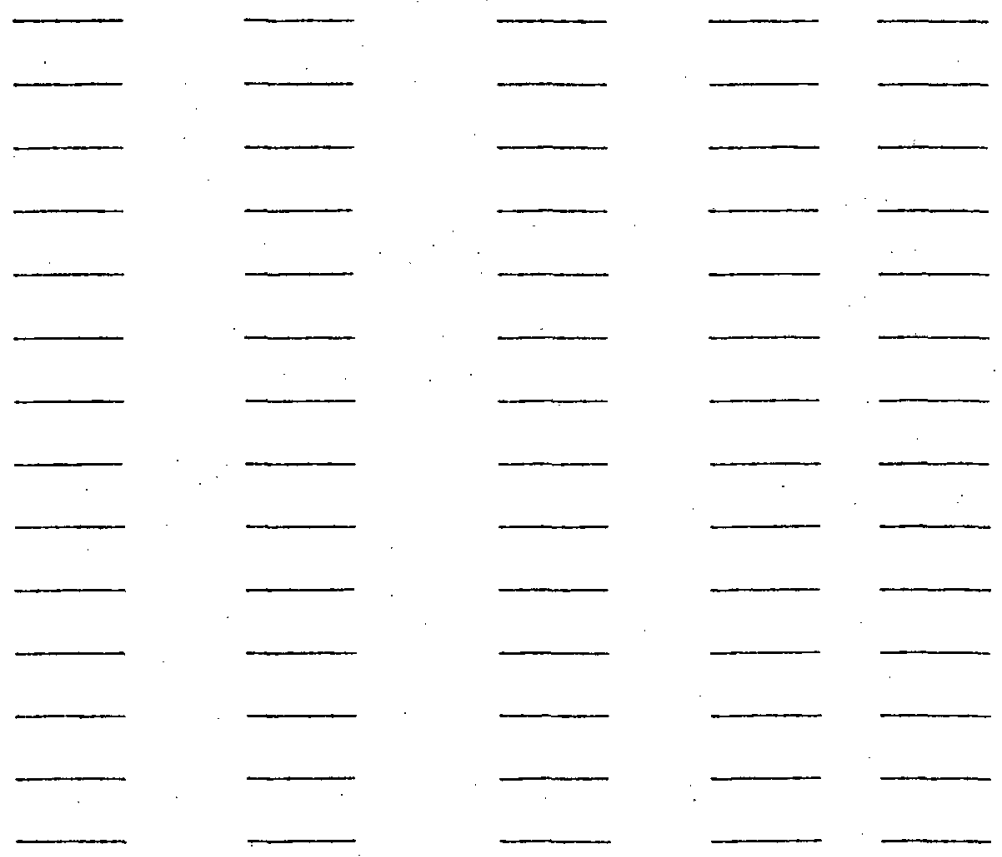


APPENDIX E

LARGE QUESTIONNAIRE 


\section{APPENDIX E}

\section{QUESTIONNAIRE}

This profile is designed to gather information and ideas from the members of the church which will help it to plan and organize its yearly program. It is a confidential document. Please place an $X$ in the appropriate box, or circle the appropriate number, and/or write in your response or comment. Thank you so much for assisting in the advancement of your church.

1. What do you like best about this church group?

2. Have you any specific recommendations for changes in existing church ministry and progams?

3. Does the church adequately meet the needs of your family?

4. How adequately do you understand the peculiar mission of the SDA church?

5. How adequate is the present overall church program for community outreach?

6. How well equipped do you feel to engage in ministry to the church and community?

7. Do you think that the church is active enough in soul winning work?

8. Are you happy with the church fellowship you experience?

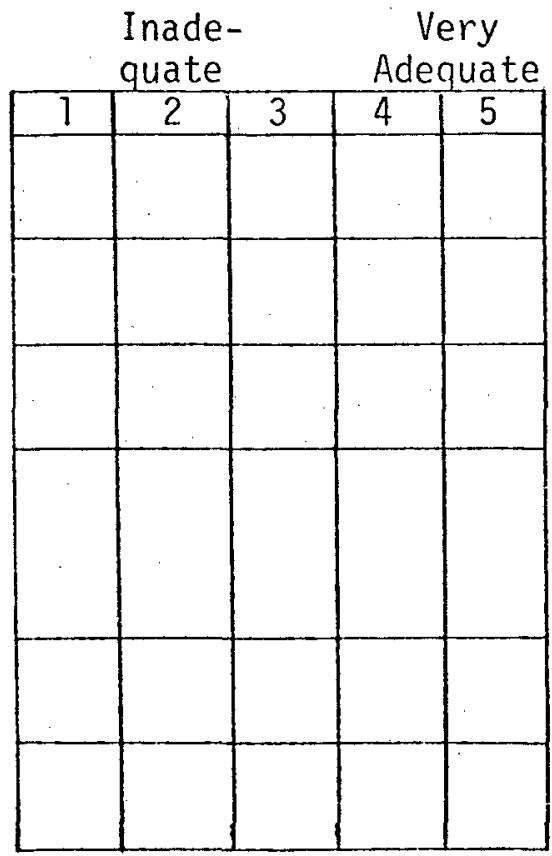


9. Do you feel that you have an adequate understanding of what God requires of a layperson in Christian service?

10. How adequately prepared do you feel to give Bible studies?

11. How satisfied are you with your active participation in the missionary work of the church?

12. How adequately do you feel that you understand the work of the pastor?

Inade-

Very quate Adequate

\begin{tabular}{|l|l|l|l|l|}
\hline 1 & 2 & 3 & 4 & 5 \\
\hline & & & & \\
& & & & \\
\hline & & & & \\
\hline & & & & \\
\hline & & & & \\
\hline
\end{tabular}

13. Which of the pastor's roles is more important? (Please rank the roles in order of importance using 1 for the most important and 8 for the least important.)

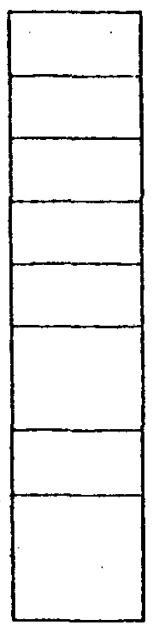

Administrator of church affairs

Visitor

Preacher and leader of worship

Teacher

Bible student and man of prayer

Church enabler--equips and helps members to minister to the community

Soul winner

Some other, such as:

14. Do you feel that your priorities in life need adjusting?

No change

1
2 prior
3 Major changes

45

15. Which activity is most important to you as a Christian? (Please rank the activities in order of importance using 1 for the most important and 7 for the least important.) 
15. Cont.

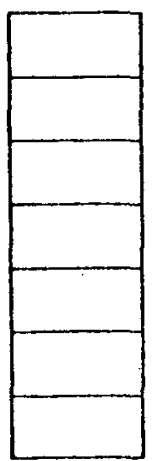

Welfare work

Prayer meeting

Soul winning through Bible studies

Church attendance

Witnessing for Christ

Good deeds

Sabbath School attendance

16. Which one of the following Spiritual Gifts do you believe God has given you for Christian service? (You may consider that God has given you more than one gift--please choose the one which is most significant.)

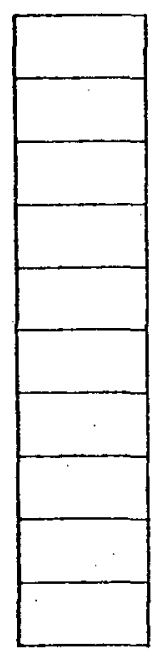

Teacher

Pastor

Evangelist--personal or public

Exhortation--stimulating or encouraging others

Administration--good organizer

Help--good at support

Stewardship--giving

Faith--prayer, belief

Not sure

Dther--please specify

17. Do you feel that you should be giving Bible studies? (Remember, not all are called to this work.)

No.

Yes, but family responsibilities hinder

Yes, but my work load is too heavy

Yes, but I feel that I lack adequate training

Yes, but some other reason hinders, e.g.:

Yes, and I am giving Bible studies at present 
18. What is your present position regarding regular active witnessing for Christ? E.g., Sunshine bands, Jailbands, regular visiting, helfare work, et cetera.

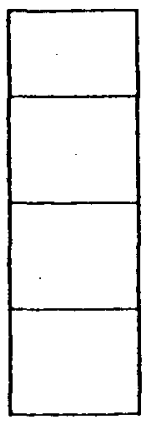

Not actively witnessing and feel no call to this work I have a desire to do this kind of work, but am not active at present

I desire to be active in this work, but some factor hinders me--please specify

I am taking part in this work at present

19. To how many families (or individuals) have you given a series of Bible studies in the past twelve months?

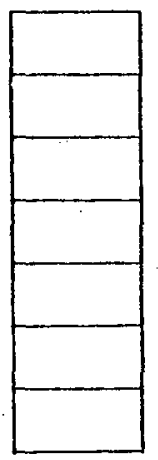

None

One

Two

Three

Four

Five

More than five

20. Do you have regular morning and evening family worship?

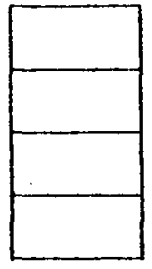

No

Only morning

Only evening

Yes, both

21. How many hours a week do you devote to some form of outreach for Christ?

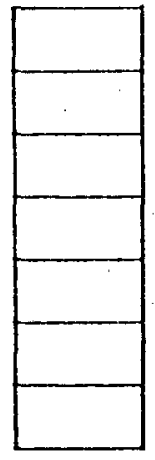

None at present

0 - 1 hour

1 - 2 hours

2 - 3 hours

3. -4 hours

4 - 5 hours

5 - hours 
22. How many hours a week could you devote to missionary work, taking a realistic assessment of your family and work responsibilities?

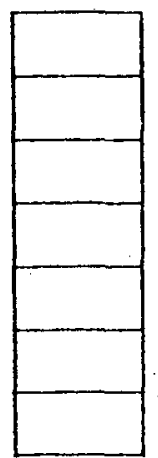

None at present

0 - 1 hour

1 - 2 hours

2 - 3 hours

3 - 4 hours

4 - 5 hours

5 - hours

23. How close do you live to Otsego?

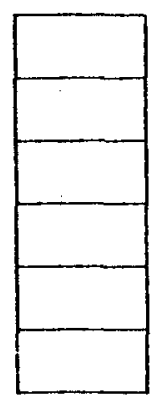

In the town

Less than 5 miles

5 - 10 miles

10 - 20 miles

20 - 30 miles

$30+$

24. Which sex are you?

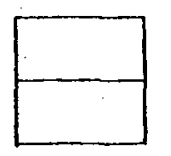

Female

Male

25. Please mark your age bracket

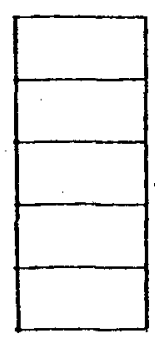

Under 20 years

20 - 30 years

30 - 50 years

$50-70$ years

$70+$

26. If a convert, can you please state your former faith:

What was the chief human agency or influence which led you to baptism? 
26 Cont.

If you have not been baptized, have you seriously considered being baptized?

27. Would you be interested in attending brief seminars on various aspects of church and family life, lay training, doctrines, spiritual gifts, et cetera?

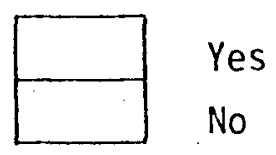

28. Please indicate which time is most suitable for you for an one hour seminar:

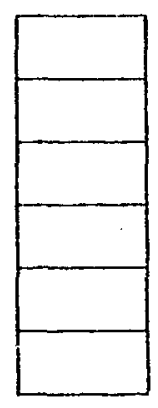

Saturday night

Sunday

Sunday night

After potluck lunch, Sabbath

Weeknight

Other (please indicate)

29. Please indicate which of the following topics would be most valuable to you. (Place a one in the most needed, two in the second, and so on.) Feel free to add and include your own suggestions.

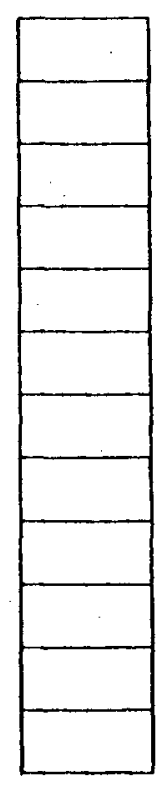

Giving Bible studies

Successful marriage

Bringing up children

Church leadership

Sabbath School preaching skills

How to mark your Bible

Spiritual Gifts

Lay witnessing

Group dynamics

Health

Modern cults and sects

Dispensationalism 
29. Cont.

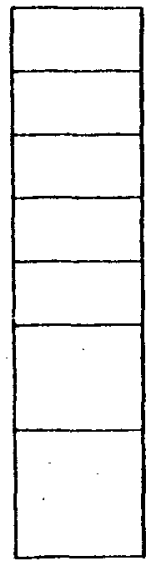

Last day events

Prophecies

Sanctuary

Salvation by Faith

Bible doctrines (please indicate):

Denominational History

Other

30. If seminars were commenced (perhaps a month or two in the future) how often do you feel they should be held?

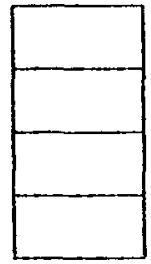

Once a week

Once a month

Twice a month

Other

\section{Community and Social}

31. Do you think this church should be involved in local community and social roles?

\begin{tabular}{|c|c|c|c|c|c|}
\hline $\begin{array}{c}\text { Not at } \\
\text { all }\end{array}$ & A little & $\begin{array}{c}\text { Less than } \\
\text { present }\end{array}$ & $\begin{array}{c}\text { About the } \\
\text { same }\end{array}$ & $\begin{array}{c}\text { More than } \\
\text { now }\end{array}$ & $\begin{array}{c}\text { Much more } \\
\text { than now }\end{array}$ \\
\hline & & & & & \\
\hline
\end{tabular}

32. If you indicate "more than now" suggest in what ways: 
33. Please check the appropriate box to indicate your level of willingness to participate in the following community activities.

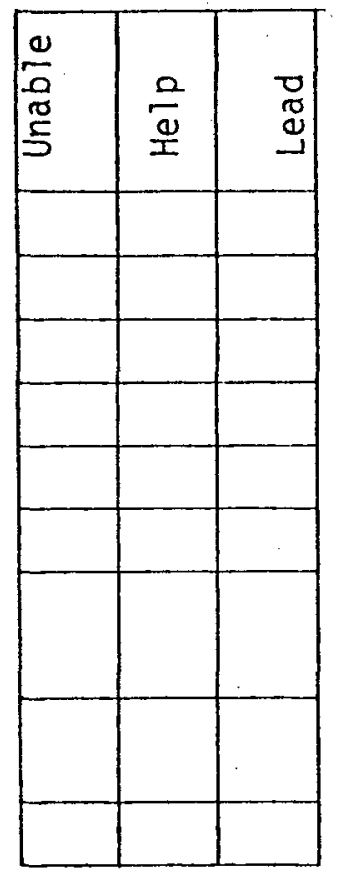

Vacation Bible School

5 Day Plan

4 DK (Alcoholic Abuse Program)

3 Cs Health Program

Sunshine Bands

Cooking Schoor

Welfare Projects (specify):

Men's service club (assists Dorcas in welfare work)

Welfare Service (Formerly Dorcas)

Other (please specify):

34. How often should the church have an evening social together?

\begin{tabular}{|c|c|c|c|c|c|}
\hline $\begin{array}{c}\text { Not at } \\
\text { all }\end{array}$ & $\begin{array}{c}\text { Once a } \\
\text { year }\end{array}$ & $\begin{array}{c}\text { Every } \\
\text { quarter }\end{array}$ & $\begin{array}{c}\text { Once a } \\
\text { month }\end{array}$ & $\begin{array}{c}\text { Every 2 } \\
\text { weeks }\end{array}$ & $\begin{array}{c}\text { Every } \\
\text { week }\end{array}$ \\
\hline
\end{tabular}

35. How often do you attend the weekly fellowship luncheon?

\begin{tabular}{|c|c|c|c|l|}
\hline Never & $\begin{array}{c}\text { Every few } \\
\text { months }\end{array}$ & $\begin{array}{c}\text { Once a } \\
\text { month }\end{array}$ & $\begin{array}{c}\text { Every 2 } \\
\text { weeks }\end{array}$ & Every week \\
\hline
\end{tabular}

36. How often should the fellowship luncheon be held?

\begin{tabular}{|l|l|l|l|l|}
\hline Not at al1 & $\begin{array}{c}\text { Every } \\
\text { quarter }\end{array}$ & $\begin{array}{c}\text { Once a } \\
\text { month }\end{array}$ & $\begin{array}{c}\text { Every 2 } \\
\text { weeks }\end{array}$ & Every week \\
\hline
\end{tabular}


37. If you attend the weekly luncheon fairly regularly, does it edify you spiritually and socially with other church members?

\begin{tabular}{|l|l|l|l|l|}
\hline Not at all & A little & Somewhat & $\begin{array}{c}\text { Quite } \\
\text { considerably }\end{array}$ & Very much \\
\hline
\end{tabular}

38. Can you suggest how social programs can be used in Christian outreach?

39. What is the best time for you to attend church social functions?

40. Do you have further suggestions on social activity within the church and/or for the community?

41. Can you please list your hobbies?

Past:

Present:

42. Please indicate on the schedule which times would be the most convenient for you to work in the community in some form of missionary outreach. (Please mark the hours available where known in the appropriate portion of the day.)

\begin{tabular}{|l|l|l|l|l|l|l|l|}
\hline & Sun. & Mon. & Tues & Wed. & Thurs. & Friday & Sabbath \\
\hline Morning & & & & & & & \\
\hline Afternoon & & & & & & & \\
\hline Evening & & & & & & & \\
\hline
\end{tabular}


Please place an $X$ for your answer, attempt to answer No or Yes as often as you can. A line is provided after each question for you to add your own comments or qualifications if you desire.

43. Can non-Seventh-day Adventist Christians be saved today?

44. Will all the saved, who are sealed at the close of probation, be Sabbath-keepers?

45. Can a willfully disobedient person be saved?

46. Do you believe that Satan will literally impersonate Jesus Christ on the earth?

47. Do you believe Martin Luther, John Calvin, and John Wesley will be lost because they did not keep the Sabbath?

48. Does the New Testament teach that only ordained pastors are ministers?

49. Do you believe there is any correlation between health and salvation?

50. Do you believe there is any correlation between dress, adornment, amusements, and salvation?

51. Do you believe there is any correlation between what you say and how you think of others, and salvation?

\begin{tabular}{|c|c|c|}
\hline No & $\begin{array}{c}\text { Un- } \\
\text { certain }\end{array}$ & Yes \\
\hline & & \\
\hline & & \\
\hline & & \\
\hline & & \\
\hline & & \\
\hline & & \\
\hline & & \\
\hline & & \\
\hline & & \\
\hline & & \\
\hline & & \\
\hline & & \\
\hline & & \\
\hline & & \\
\hline & & \\
\hline & & \\
\hline & & \\
\hline & & \\
\hline & & \\
\hline
\end{tabular}


52. If you had to choose between losing your job and breaking the Sabbath, would you break the Sabbath and work?

53. If you had to choose between going to jail and remaining there, or working on Sabbath, would you do to jail?

54. Do you believe that one true prophet can be more inspired than another true prophet?

55. Do you believe that acceptance of Jesus Christ as your Saviour is the most important salvation doctrine in the church? If not please suggest another

56. Do you believe God forgives us and grants us entry to heaven because of faith in Jesus and our own good works?

57. Do you believe Ellen G. White was as inspired as the Bible writers were?

58. Do you believe that if you should die tonight, you would be resurrected to eternal life when Jesus returns?

59. Is it more important to keep the Sabbath correctly than to help someone in need on that day?

\begin{tabular}{|l|l|l|}
\hline No. & $\begin{array}{c}\text { Un- } \\
\text { certain }\end{array}$ & Yes \\
\hline & & \\
\hline & & \\
\hline & & \\
\hline & & \\
\hline & & \\
\hline & & \\
\hline & & \\
\hline & & \\
\hline
\end{tabular}


60. Is inerrancy in every statistic and detail of the Scripture an absolute necessity if it is inspired?

61. Can a Christian remain loving and living in the same house with an unbelieving spouse?

62. Is it better to die than to commit a deliberate sin?

63. Is it true that God's justice is superior to His love?

64. Is it true that Satan has committed the unpardonable $\sin$ ?

65. Is it true that the cross has more to do with our salvation than the Sabbath?

66. Do you believe there are other ways to salvation (i.e., through non-Christian religions) without going through Jesus Christ?

67. Do you believe we fully understand now all the prophecies of Daniel and Revelation?

68. Do you believe the "Speaking in Tongues" of the New Testament involved "languages" unknown anywhere on the earth?

\begin{tabular}{|l|l|l|}
\hline No & $\begin{array}{c}\text { Un- } \\
\text { certain }\end{array}$ & Yes \\
\hline & & \\
\hline & & \\
\hline & & \\
\hline & & \\
\hline & & \\
\hline & & \\
\hline & & \\
\hline & & \\
\hline & & \\
\hline & & \\
\hline & & \\
\hline & & \\
\hline & & \\
\hline & & \\
\hline & & \\
\hline & & \\
\hline
\end{tabular}


69. Do you believe the Holy Spirit has given you scme Spiritual Gifts?

70. Do you believe women should be ordained to the gospel ministry?

71. If you could live your life over aga in would you change things so that it would be quite different than what it now is?

72. Do you believe that if wronged, you would take another Adventist or Adventist institution to court to obtain what you deserve to receive?

\begin{tabular}{|l|c|c|}
\hline No & $\begin{array}{c}\text { Un- } \\
\text { certain }\end{array}$ & Yes \\
\hline & & \\
\hline & & \\
\hline & & \\
& & \\
\hline & & \\
\hline
\end{tabular}




\section{QUESTIONNAIRE}

Directions:

Please respond to the following statements frankly and honestly.

Do not place your name on this questionnaire or on the other answer sheet.

A1l answers will be kept confidential.

Please answer all questions.

For each statement in this questionnaire, mark the appropriate number on your answer sheet which best represents your feelings.

Number 1 means that you strongly agree

Number 2 means that you tend to agree more than disagree

Number 3 means that you neither agree nor disagree

Number 4 means that you tend to disagree more than agree

Number 5 means that you strongly disagree with the given statement

Mark only one of the above possibilities

for each question.

73. I am a person who is usually ready to share my faith.

74. I believe every Christian should consider himself a witness.

75. I don't understand why people would want to become missionaries.

76. I have a personal relationship with Christ.

77. If I picked up a hitchhiker I would probably witness to him about my faith in Christ.

78. Belief in God is fundamental to my life. with the given statement

with the given statement

with the given statement

with the given statement 
79. You can't witness unless you have an experierice with Christ.

80. My chances of being saved are so slim it isn't worth the effort.

81. Having a good relationship with Christ is the most important thing in my life.

82. People who are especially busy should not be given any witness responsibilities.

83. I feel no obligation to witness to others.

84. My friends know me as a committed Christian.

85. If I had opportunity to go on a door to door witness band I would go.

86. I don't like to talk about Spiritual things with others.

87. Even if I were given the opportunity I doubt if I would talk to someone about Christ.

88. I might be happier if I did not know about Adventism.

89. I enjoy telling others about my Christian experience.

90. Witnessing is really for just some Christians.

91. I would feel at ease if called on to tell of my faith.

92. I would feel free to invite my non-Seventh-day Adventist friends to church with me.

93. People who know me wouldn't stop swearing when I came into the room.

94. Not every Seventh-day Adventist Christian has the capability of winning someone to Christ.

95. Feeling the way I do about religion is very important to being the kind of person I want to be.

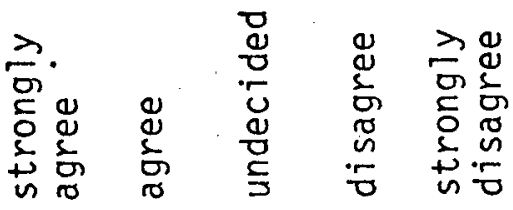

$\begin{array}{lllll}1 & 2 & 3 & 4 & 5\end{array}$

$\begin{array}{lllll}1 & 2 & 3 & 4 & 5\end{array}$

$\begin{array}{lllll}1 & 2 & 3 & 4 & 5\end{array}$

$1 \quad 2 \quad 3 \cdot 4 \quad 5$

$\begin{array}{lllll}1 & 2 & 3 & 4 & 5\end{array}$

$\begin{array}{lllll}1 & 2 & 3 & 4 & 5\end{array}$

$\begin{array}{lllll}1 & 2 & 3 & 4 & 5\end{array}$

$\begin{array}{lllll}1 & 2 & 3 & 4 & 5\end{array}$

$\begin{array}{lllll}1 & 2 & 3 & 4 & 5\end{array}$

$\begin{array}{lllll}1 & 2 & 3 & 4 & 5\end{array}$

$\begin{array}{lllll}1 & 2 & 3 & 4 & 5\end{array}$

$1 \quad 2 \quad 3 \quad 4 \quad 5$

$\begin{array}{lllll}1 & 2 & 3 & 4 & 5\end{array}$

$\begin{array}{lllll}1 & 2 & 3 & 4 & 5\end{array}$

$\begin{array}{lllll}1 & 2 & 3 & 4 & 5\end{array}$

$\begin{array}{lllll}1 & 2 & 3 & 4 & 5\end{array}$

$\begin{array}{lllll}1 & 2 & 3 & 4 & 5\end{array}$ 
96. I can't imagine myself witnessing.

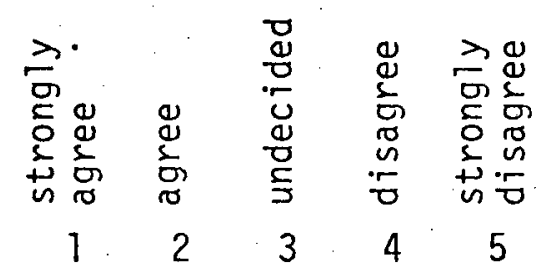

97. I would feel free to talk to a close friend about my relationship with Christ.

98. When I think of witnessing I think of going out with groups on Sabbath afternoon.

99. I am afraid to share my faith with others.

100. Christian witness is essential to finishing God's work.

101. I would witness more if I knew how to go about it.

102. I am not the type to initiate any conversations on religion.

103. When I think of witness I have good feelings.

104. Witnessing is for those with outgoing personalities.

105. If given the chance I would give Bible studies to a non-Seventh-day Adventist.

106. Some jobs people hold don't really require the person to be a witness.

107. Witnessing should be left to those professionally trained to do it.

108. Witnessing to okay for those who like going door to door.

109. Witness really involves all of my life.

110. I find that my ideas on religion have a considerable influence on my views in other areas.

111. I would be proud to tell someone I am a Seventh-day Adventist.

112. Witnessing embarrasses me.

113. I like people too much to try to push my religion on them.

$\begin{array}{lllll}1 & 2 & 3 & 4 & 5\end{array}$

$\begin{array}{lllll}1 & 2 & 3 & 4 & 5\end{array}$

$\begin{array}{llll}2 & 3 & 4 & 5\end{array}$

$\begin{array}{lllll}1 & 2 & 3 & 4 & 5\end{array}$

$\begin{array}{lllll}1 & 2 & 3 & 4 & 5\end{array}$

$\begin{array}{llll}1 & 3 & 4 & 5\end{array}$

$\begin{array}{lllll}1 & 2 & 3 & 4 & 5\end{array}$

12345

$\begin{array}{lllll}1 & 2 & 3 & 4 & 5\end{array}$

$\begin{array}{lllll}1 & 2 & 3 & 4 & 5\end{array}$

$\begin{array}{llll}1 & 3 & 4 & 5\end{array}$

$\begin{array}{lllll}1 & 2 & 3 & 4 & 5\end{array}$


114. Daily Scripture study is not really vital to living a Christian life.

115. I would consider myself a worldly person.

116. Belief in God makes life on earth worthwhile.

117. Others who wanted to tell a dirty story wouldn't stop because I was in the group.

118. I like the positive feeling I have when I talk to someone about my religion.

119. I would not normally seek out opportunities to share my faith.

120. I should have more witnessing contacts with people of non-Seventh-day Adventist faith.

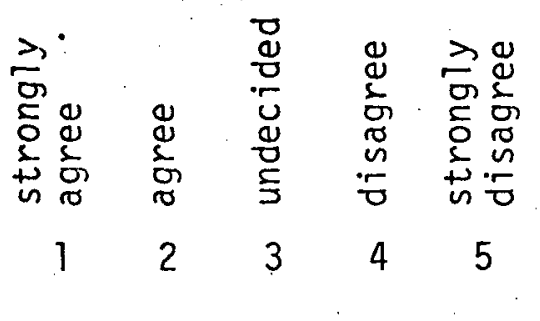

$\begin{array}{lllll}1 & 2 & 3 & 4 & 5\end{array}$

12345

12345

$\begin{array}{lllll}1 & 2 & 3 & 4 & 5\end{array}$

$\begin{array}{lllll}1 & 2 & 3 & 4 & 5\end{array}$

$\begin{array}{lllll}1 & 2 & 3 & 4 & 5\end{array}$ 


\section{APPENDIX $F$}

RESPONSES TO LARGE QUESTIONNAIRE 


\section{APPENDIX F}

\section{RESPONSES TO LARGE QUESTIONNAIRE}

1. What do you like best about this church group? Like a family, unity, love of Jesus here, friendly, people very close, small enough to know everyone, I just like it, sincere, true interest in others.

2. Have you any specific recommendations for changes in existing church ministry and progams?

Column in newspaper, more talk of Christ instead of law-keeping, more involved in soul-winning, begin and end church service on time, a full-time pastor, add a Bible-worker, reach out with more love to others.

3. Does the church adequately meet the needs of your family?

4. How adequately do you understand the peculiar mission of the SDA church?

5. How adequate is the present overall church prograni for community outreach?

6. How well equipped do you feel to engage in ministry to the church and comniunity?

7. Do you think that the church is active enough in soul winning work?

8. Are you happy with the church fellowship you experience?

Inade-
quate
\begin{tabular}{|l|l|l|l|l|} 
Very \\
\hline 1 & 2 & 3 & 4 & 5 \\
\hline 1 & 1 & 5 & 2 & 6 \\
\hline 1 & & 2 & 8 & 4 \\
\hline 2 & 2 & 7 & 3 & \\
\hline & & & & \\
\hline 4 & 4 & 6 & 1 & \\
\hline 1 & 5 & 7 & 2 & \\
\hline 1 & 2 & 2 & 4 & 6 \\
\hline
\end{tabular}


9. Do you feel that you have an adequate understanding of what God requires of a layperson in Christian service?

10. How adequately prepared do you feel to give Bible studies?

11. How satisfied are you with your active participation in the missionary work of the church?

12. How adequately do you feel that you understand the work of the pastor?

Inade-

Very quate Adequate

\begin{tabular}{|l|l|l|l|l|}
\hline 1 & 2 & 3 & 4 & 5 \\
\hline 1 & 3 & 4 & 6 & 1 \\
\hline 7 & 2 & 6 & & \\
\hline 1 & 2 & 7 & 3 & \\
\hline 2 & 1 & 4 & 5 & 2 \\
\hline
\end{tabular}

13. Which of the pastor's roles is more important? (Please rank the roles in order of importance using 1 for the most important and 8 for the least important.)

\begin{tabular}{|c|c|}
\hline 5.6 & Administrator of church affairs \\
\hline 5.29 & Visitor \\
\hline 2.85 & Preacher and leader of worship \\
\hline 3.43 & Teacher \\
\hline 2.5 & Bible student and man of prayer \\
\hline 5.21 & $\begin{array}{l}\text { Church enabler--equips and helps members to } \\
\text { minister to the cormunity }\end{array}$ \\
\hline 3.43 & Soul winner \\
\hline \multirow[t]{2}{*}{6.7} & Some other, such as: Counselor \& advisor, helping \\
\hline & and guiding members \\
\hline
\end{tabular}

14. Do you feel that your priorities in life need adjusting? No change

$\begin{array}{ll}1 & 2 \\ 1 & 1\end{array}$

$$
\begin{aligned}
& 3 \\
& 8
\end{aligned}
$$

Major changes

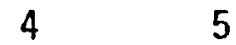

4

15. Which activity is most important to you as a Christian?

(Please rank the activities in order of importance using

1 for the most important and 7 for the least important.) 
15. Cont.

\begin{tabular}{|c|c|c|}
\hline 5 & 4.33 & Welfare work \\
\hline 7 & 5.2 & Prayer meeting \\
\hline 4 & 4.0 & Soul winning through Bible studies \\
\hline 2 & 3.53 & Church attendance \\
\hline 1 & 1.33 & Witnessing for Christ. \\
\hline 3 & 3.66 & Good deeds \\
\hline 6 & 5.07 & Sabbath School attendance \\
\hline
\end{tabular}

16. Which one of the following Spiritual Gifts do you believe God has given you for Christian service? (You may consider that God has given you more than one gift--please choose the one which is most significant.)

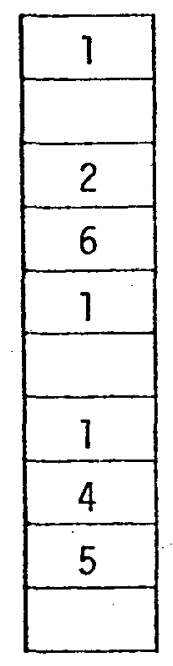

Teacher

Pastor

Evangelist--personal or public

Exhortation--stimulating or encouraging others

Administration--good organizer

Help--good at support

Stewardship--giving

Faith--prayer, belief

Not sure

Other--please specify

17. Do you feel that you should be giving Bible studies? (Remember, not all are called to this work.)

\begin{tabular}{|l|}
\hline 7 \\
\hline 1 \\
\hline 1 \\
\hline 5 \\
\hline 3 \\
\hline 2 \\
\hline
\end{tabular}

No

Yes, but family responsibilities hinder

Yes, but my work load is too heavy

Yes, but I feel that I lack adequate training

Yes, but some other reason hinders, e.g.:

Yes, and I am giving Bible studies at present 
18. What is your present position regarding regular active witnessing for Christ? E.g., Sunshine bands, Jailbands, regular visiting, h'elfare work, et cetera.

\begin{tabular}{|c|}
\hline 2 \\
\hline 3 \\
\hline 2 \\
\hline 6 \\
\hline
\end{tabular}

Not actively witnessing and feel no call to this work I have a desire to do this kind of work, but am not active at present

I desire to be active in this work, but some factor hinders me--please specify

I am taking part in this work at present

19. To how many families (or individuals) have you given a series of Bible studies in the past twelve months?

\begin{tabular}{|c|c|}
\hline 10 & None \\
\hline 2 & One \\
\hline 2 & Two \\
\hline & Three \\
\hline & Four \\
\hline & Five \\
\hline 1 & More \\
\hline
\end{tabular}

20. Do you have regular morning and evening family worship?

\begin{tabular}{|l|}
\hline 5 \\
\hline 4 \\
\hline 5 \\
\hline 1 \\
\hline
\end{tabular}

No

Only morning

Only evening

Yes, both

21. How many hours a week do you devote to some form of outreach for Christ?

\begin{tabular}{|l|}
\hline 4 \\
\hline 3 \\
\hline 1 \\
\hline \\
\hline 2 \\
\hline 2 \\
\hline 2 \\
\hline
\end{tabular}

None at present

0 - 1 hour

1 - 2 hours

2 - 3 hours

3 - 4 hours

4 - 5 hours

5 - hours 
22. How many hours a week could you devote to missionary work, taking a realistic assessment of your family and work responsibilities?

\begin{tabular}{|c|c|}
\hline 3 & None at present \\
\hline 2 & $0-1$ hour \\
\hline 2 & $1-2$ hours \\
\hline & $2-3$ hours \\
\hline 1 & $3-4$ hours \\
\hline 2 & $4-5$ hours \\
\hline 4 & 5 - hours \\
\hline
\end{tabular}

23. How close do you live to Otsego?

\begin{tabular}{|l|}
\hline \\
\hline 6 \\
\hline 6 \\
\hline 1 \\
\hline 2 \\
\hline
\end{tabular}

In the town

Less than 5 miles

5 - 10 miles

$10-20$ miles

20 - 30 miles

$30+$

24. Which sex are you?

\begin{tabular}{|c|l|l|}
\hline 11 & Female \\
\hline 4 & Male
\end{tabular}

25. Please mark your age bracket

\begin{tabular}{|l|l|l}
\hline & Under 20 years \\
$20-30$ years \\
\hline 4 & \begin{tabular}{l}
$30-50$ years \\
$50-70$ years \\
\hline 7
\end{tabular} \\
\hline 1 & $70+$
\end{tabular}

26. If a convert, can you please state your former faith: 3 none; 7 protestant groups

What was the chief human agency or influence which led you to baptism? Relatives, family witness, friends, just wanted to start a new life, evangelistic meeting 
26 Cont.

If you have not been baptized, have you seriously considered being baptized?

27. Would you be interested in attending brief seminars on various aspects of church and family life, lay training, doctrines, spiritual gifts, et cetera?

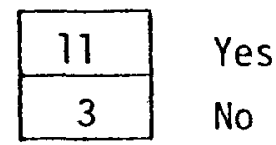

28. Please indicate which time is most suitable for you for an one. hour seminar:

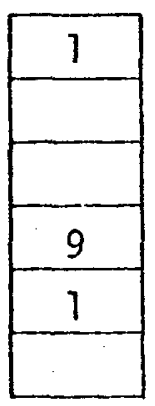
Saturday night
Sunday
Sunday night
After potluck lunch, Sabbath
Weeknight
Other (please indicate)

29. Please indicate which of the following topics would be most valuable to you. (Place a one in the most needed, two in the second, and so on.) Feel free to add and include your own suggestions.

\begin{tabular}{|c|c|c|}
\hline 7 & 8.0 & Giving Bible studies \\
\hline 8 & 8.11 & Successful marriage \\
\hline 10 & 8.67 & Bringing up children \\
\hline 17 & 12.44 & Church leadership \\
\hline 13 & 11.89 & Sabbath School preaching skills \\
\hline 6 & 7.3 & How to mark your Bible \\
\hline 3 & 5.11 & Spiritual Gifts \\
\hline 2 & 4.83 & Lay witnessing \\
\hline 15 & 12.1 & Group dynamics \\
\hline ר & 11.0 & Health \\
\hline & 12.2 & Modern cults and sects \\
\hline & 11.89 & Dispensationalism \\
\hline
\end{tabular}


29. Cont.

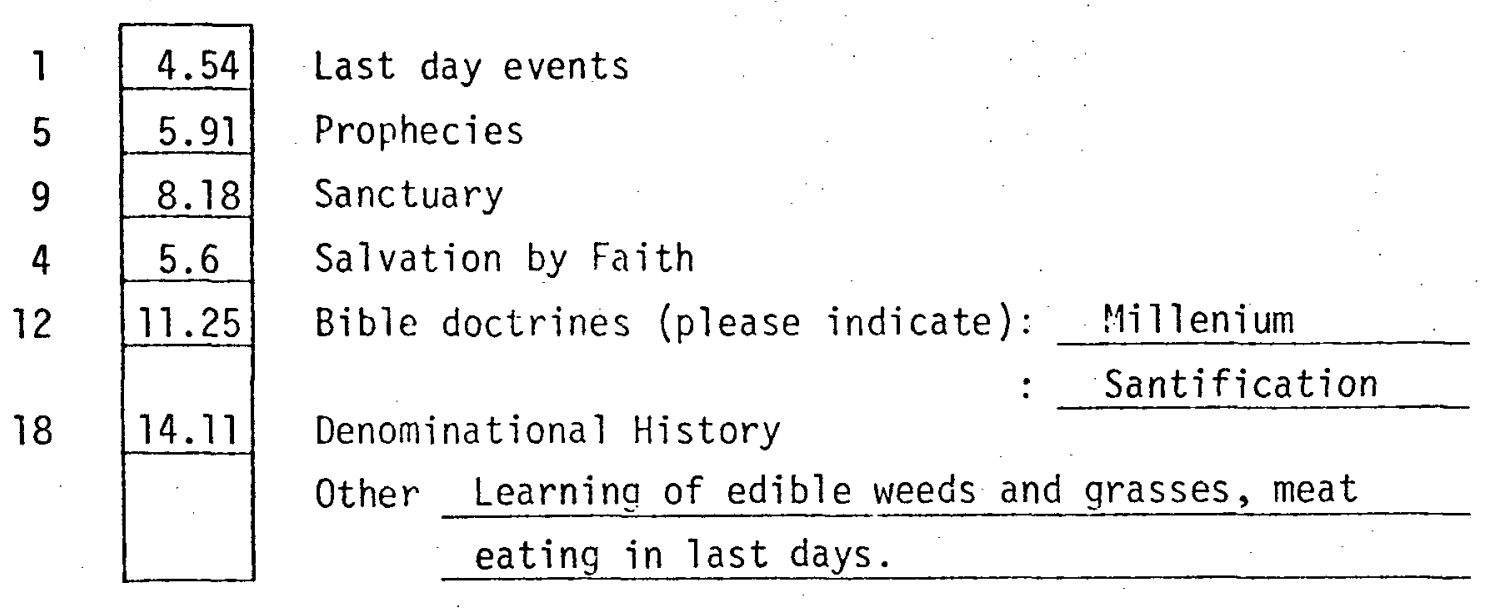

30. If seminars were commenced (perhaps a month or two in the future) how often do you feel they should be held?

\begin{tabular}{|l|}
\hline 5 \\
\hline 3 \\
\hline 5 \\
\hline
\end{tabular}
Once a week
Once a month
Twice a month
other

\section{Community and Social}

31. Do you think this church should be involved in local community and social roles?

\begin{tabular}{|c|c|c|c|c|c|}
\hline $\begin{array}{c}\text { Not at } \\
\text { all }\end{array}$ & A little & $\begin{array}{c}\text { Less than } \\
\text { present }\end{array}$ & $\begin{array}{c}\text { About the } \\
\text { same }\end{array}$ & $\begin{array}{c}\text { More than } \\
\text { now }\end{array}$ & $\begin{array}{c}\text { Much more } \\
\text { than now }\end{array}$ \\
\hline & & 4 & 4 & 6 \\
\hline
\end{tabular}

32. If you indicate "more than now" suggest in what ways: Open welfare center; 5-day plan, Sunshine band, ads in paper, outside church in summer, cooking classes, health and exercise classes, Friday night service for community. 
33. Please check the appropriate box to indicate your level of willingness to participate in the following community activities.

\begin{tabular}{|c|c|c|}
\hline $\begin{array}{l}\frac{0}{0} \\
\stackrel{0}{5} \\
\frac{5}{5}\end{array}$ & $\frac{0}{x}$ & $\begin{array}{l}0 \\
0 \\
\\
\end{array}$ \\
\hline 3 & 7 & 1 \\
\hline 1 & 9 & \\
\hline 1 & 9 & 1 \\
\hline 2 & 6 & 1 \\
\hline 2 & 6 & \\
\hline 4 & 4 & 1 \\
\hline 1 & 7 & 1 \\
\hline 1 & 3 & \\
\hline 2 & 8 & 1 \\
\hline
\end{tabular}

Vacation Bible School

5 Day Plan

4 DK. (Alcoholic Abuse Program)

3 Cs Health Program

Sunshine Bands

Cooking School

Welfare Frojects (specify): Mending clothing,

food distribution, send some kids to camp

Men's service club. (assists Dorcas in welfare work)

Welfare Service (Formerly Dorcas)

Other (please specify): Christ our Righteousness seminars

34. How often should the church have an evening social together?

\begin{tabular}{|c|c|c|c|c|c|}
\hline $\begin{array}{c}\text { Not at } \\
\text { all }\end{array}$ & $\begin{array}{c}\text { Once a } \\
\text { year }\end{array}$ & $\begin{array}{c}\text { Every } \\
\text { quarter }\end{array}$ & $\begin{array}{c}\text { Once a } \\
\text { month }\end{array}$ & $\begin{array}{c}\text { Every 2 } \\
\text { weeks } \\
6\end{array}$ & $\begin{array}{c}\text { Every } \\
\text { week } \\
1\end{array}$ \\
\hline
\end{tabular}

35. How often do you attend the weekly fellowship luncheon?

\begin{tabular}{|c|c|c|c|c|}
\hline Never & $\begin{array}{c}\text { Every few } \\
\text { months }\end{array}$ & $\begin{array}{c}\text { Once a } \\
\text { month }\end{array}$ & $\begin{array}{c}\text { Every 2 } \\
\text { weeks }\end{array}$ & Every week \\
\hline 1 & 5 & 1 & & 8 \\
\hline
\end{tabular}

36. How often should the fellowship luncheon be held?

\begin{tabular}{|c|c|c|c|c|}
\hline Not at all & $\begin{array}{c}\text { Every } \\
\text { quarter } \\
1\end{array}$ & $\begin{array}{c}\text { Once a } \\
\text { month } \\
2\end{array}$ & $\begin{array}{c}\text { Every } 2 \\
\text { weeks } \\
1\end{array}$ & $\begin{array}{c}\text { Every week } \\
9\end{array}$ \\
\hline
\end{tabular}


37. If you attend the weekly luncheon fairly regularly, does it edify you spiritually and socially with other church members?

$\begin{array}{cccc}\text { Not at all A little } & \text { Somewhat } & \begin{array}{c}\text { Quite } \\ \text { considerably }\end{array} & \text { Very much } \\ 1 & 1 & 5 & \end{array}$

38. Can you suggest how social programs can be used in Christian outreach?

Christian love, more personal contacts--bring them along. More action less talk on this.

39. What is the best time for you to attend church social functions? Early afternoons, after 7:00 p.m. (3); Sunday, Sunday afternoon, Saturday night, anytime, weekends.

40. Do you have further suggestions on social activity within the church and/or for the community?

Outdoor things--sports, fishing, hiking, camping, swimming, planting, guest speakers from other denominations, ice ream secials, s]jiding parties, more for the community, sing-spiration for community.

4. Can you please list your hobbies?

Past: Farming, crotcheting, stamp collecting, post-card collecting, sports, roller skating, swimming, movies, models, baseball, indoor plants, etc.

Present: Breakmaking, woodworking, bowling, golf, gardening, stamp collecting, crotcheting, cooking, paintina, drawing, reading, sewing, restoring antiques, bike riding, group games, ping-pong, racket-ball, arts and crafts.

42. Please indicate on the schedule which times would be the most convenient for you to work in the community in some form of missionary outreach. (Please niark the hours available where known in the appropriate portion of the day.)

\begin{tabular}{|l|c|c|c|c|c|c|c|}
\hline & Sun. & Mon. Tues & Wed. & Thurs & Friday & Sabbath \\
\hline Morning & & & 3 & & 2 & & \\
\hline Afternoon & 1 & 2 & 3 & 1 & 2 & 1 & 6 \\
\hline Evening & 1 & & 1 & 1 & 1 & 2 & 4 \\
\hline
\end{tabular}


Please place an $X$ for your answer, attempt to answer No or Yes as often as you can. A line is provided after each question for you to add your own comments or qualifications if you desire.

43. Can non-Seventh-day Adventist Christians be saved today?

44. Will all the saved, who are sealed at the close of probation, be Sabbath-keepers?

45. Can a willfully disobedient person be saved?

46. Do you believe that Satan will literally impersonate Jesus Christ on the earth?

47. Do you believe Martin Luther, John Calvin, and John Wesley will be lost because they did not keep the Sabbath?

48. Does the New Testament teach that only ordained pastors are ministers?

\begin{tabular}{|c|c|c|}
\hline No & $\begin{array}{c}\text { Un- } \\
\text { certain }\end{array}$ & Yes \\
\hline & & 15 \\
\hline 4 & 3 & 8 \\
\hline 10 & 2 & 3 \\
\hline & 1 & 14. \\
\hline 14 & 1 & \\
\hline 7 & 6 & \\
\hline 4 & 1 & 9 \\
\hline 2 & & 13 \\
\hline 3 & & 12 \\
\hline
\end{tabular}

49. Do you believe there is any correlation between health and salvation?

50. Do you believe there is any correlation between dress, adornment, amusements, and salvation?

51. Do you believe there is any correlation between what you say and how you think of others, and salvation? 
52. If you had to choose between losing your job and breaking the Sabbath, would you break the Sabbath and work?

\begin{tabular}{|c|c|c|}
\hline No & $\begin{array}{c}\text { Un- } \\
\text { certain }\end{array}$ & Yes \\
\hline 11 & 3 & \\
\hline & 2 & 12 \\
\hline 5 & 3 & 7 \\
\hline & & 14 \\
\hline 11 & 1 & 2 \\
\hline 1 & 1 & 13 \\
\hline & 3 & 12 \\
\hline 10 & 2 & 1 \\
\hline
\end{tabular}

59. Is it more important to keep the Sabbath correctly than to help someone in need on that day? jail and remaining there, or working on Sabbath, would you do to jail?

54. Do you believe that one true prophet can be more inspired than another true prophet?

55. Do you believe that acceptance of Jesus Christ as your Saviour is the most important salvation doctrine in the church? if not piease suggesi another

56. Do you believe God forgives us and grants us entry to heaven because of faith in Jesus and our own good works?

57. Do you believe Ellen $G$. White was as inspired as the Bible writers were?

58. Do you believe that if you should die tonight, you would be resurrected to eternal life when Jesus returns?

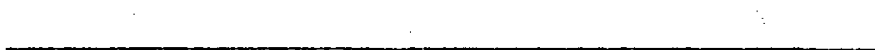


60. Is inerrancy in every statistic and detail of the Scripture an absolute necessity if it is inspired?

61. Can a Christian remain loving and living in the same house with an unbelieving spouse?

62. Is it better to die than to commit a deliberate sin?

63. Is it true that God's justice is superior to His love?

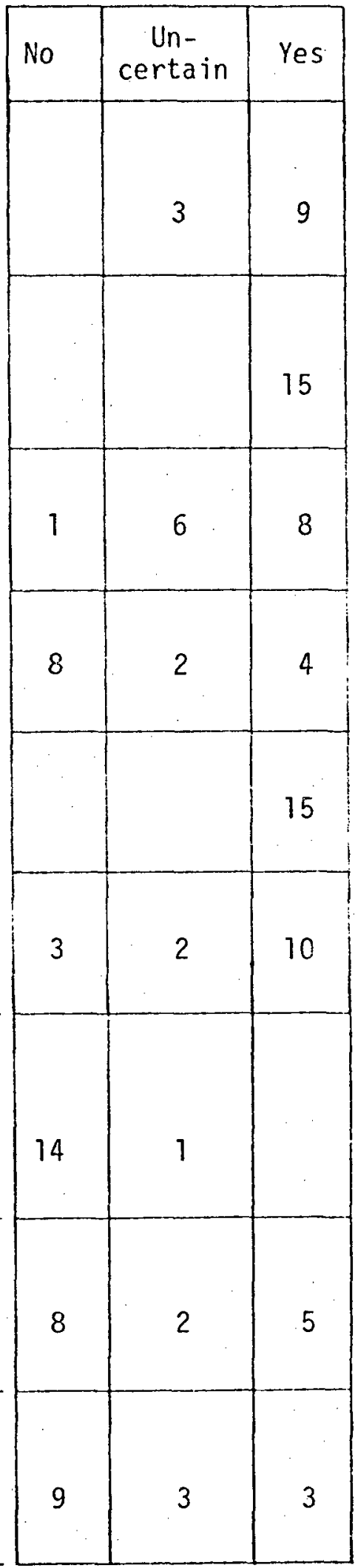

67. Do you believe we fully understand now all the prophecies of Daniel and Revelation?

68. Do you believe the "Speaking in Tongues" of the New Testament involved "languages" unknown anywhere on the earth? 
69. Do you believe the Holy Spirit has given you some Spiritual Gifts?

\begin{tabular}{|c|c|c|}
\hline No & $\begin{array}{c}\text { Un- } \\
\text { certain }\end{array}$ & Yes \\
\hline & 3 & 12 \\
\hline 4 & 7 & 4 \\
\hline 7 & 2 & 6 \\
\hline 12 & 3 & \\
\hline
\end{tabular}

70. Do you believe women should be ordained to the gospel ministry?

71. If you could live your life over aga in would you change things. so that it would be quite different than what it now is?

72. Do you believe that if wronged, you would take another Adventist or Adventist insti. tution to court to obtain what you deserve to receive? 


\section{QUESTIONNAIRE}

\section{Directions:}

Please respond to the following statements frankly and honestly.

Do not place your name on this questionnaire or on the other answer sheet.

All answers will be kept confidential.

Please answer all questions.

For each statement in this questionnaire, mark the appropriate number on your answer sheet which best represents your feelings.

Number 1 means that you strongly agree

Number 2 means that you tend to agree more than disagree

Number 3 means that you neither agree nor disagree

Number 4 means that you tend to disagree more than agree

Number 5 means that you strongly disagree with the given statement

Mark only one of the above possibilities for each question. with the given statement

with the given statement

with the given statement

with the given statement
73. I am a person who is usually ready to share my faith.

74. I believe every Christian should consider himself a witness.

75. I don't understand why people would want to become missionaries.

76. I have a personal relationship with Christ.

77. If I picked up a hitchhiker I would probably witness to him about my faith in Christ.

78. Belief in God is fundamental to my life.

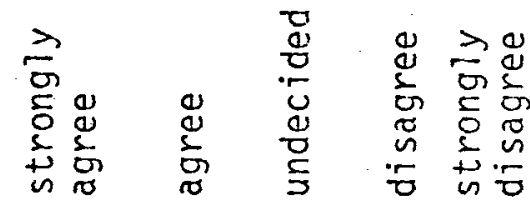

$\begin{array}{lllll}1 & 2 & 3 & 4 & 5\end{array}$

$\underline{4} \quad \underline{8} \quad \underline{3}$

$\begin{array}{lllll}1 & 2 & 3 & 4 & 5\end{array}$

$10 \quad \underline{4}$

$\begin{array}{ccccc}1 & 2 & 3 & 4 & 5 \\ 1 & & \frac{1}{3} & \frac{7}{4} & \frac{5}{5}\end{array}$

$\underline{9} \quad \underline{6}$

$\begin{array}{lllll}1 & 2 & 3 & 4 & 5\end{array}$

1. $4 \quad 7 \quad 1$

$\begin{array}{lllll}1 & 2 & 3 & 4 & 5\end{array}$

$12 \quad 3$ 
79. You can't witness unless you have an experience with Christ.

80. My chances of being saved are so slim it isn't worth the effort.

81. Having a good relationship with Christ is the most important thing in my life.

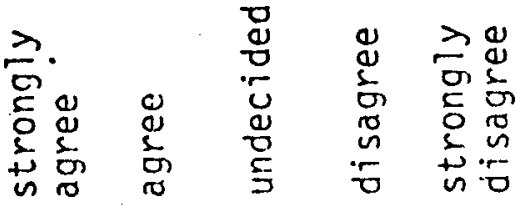

$\begin{array}{lllll}1 & 2 & 3 & 4 & 5 \\ 6 & 5 & 1 & 1 & 1\end{array}$

$\begin{array}{lllll}1 & 2 & 3 & 4 & 5\end{array}$

$1 \quad \underline{2} \quad \underline{9}$

$\begin{array}{rrrrr}1 & 2 & 3 & 4 & 5\end{array}$

82. People who are especially busy should not be given any witness responsibilities.

$\begin{array}{lllll}1 & 2 & 3 & 4 & 5 \\ 1 & & 1 & 6 & \underline{7}\end{array}$

83. I feel no obligation to witness to others.

84. My friends know me as a committed Christian.

85. If I had opportunity to go on a door to door witness band I would go.

86. I don't like to talk about Spiritual things with others.

87. Even if I were given the opportunity I doubt if I would talk to someone about Christ.

88. I might be happier if I did not know about Adventism.

89. I enjoy telling others about my Christian experience.

90. Witnessing is really for just some Christians.

91. I would feel at ease if called on to tell of my faith.

92. I would feel free to invite my non-Seventh-day Adventist friends to church with ine.

$\begin{array}{lllll}1 & 2 & 3 & 4 & 5\end{array}$

$\begin{array}{llll}2 & 1 & 3 & 8\end{array}$

$\begin{array}{lllll}1 & 2 & 3 & 4 & 5\end{array}$

$\begin{array}{llll}6 & 6 & 2 & 1\end{array}$

$\begin{array}{lllll}1 & 2 & 3 & 4 & 5\end{array}$

$\begin{array}{llll}4 & \underline{6} & \underline{3} & 1\end{array}$

$\begin{array}{lllll}1 & 2 & 3 & 4 & 5 \\ 1 & 1 & 2 & 8 & 3\end{array}$

$\begin{array}{lllll}1 & 2 & 3 & 4 & 5 \\ & & \underline{3} & \underline{8} & \underline{3}\end{array}$

People who know me wouldn't stop

swearing when I came into the room.

94. Not every Seventh-day Adventist Christian has the capability of winning someone to Christ.

95. Feeling the way I do about religion is very important to being the kind of person I want to be.

1

$\begin{array}{llll}2 & 3 & 4 & 5 \\ 1 & & \underline{6} & \underline{7}\end{array}$

$\begin{array}{lllll}1 & 2 & 3 & 4 & 5\end{array}$

$\begin{array}{lllll}3 & 6 & 3 & 1\end{array}$

$\begin{array}{lllll}1 & 2 & 3 & 4 & 5\end{array}$

$1 \quad \underline{6} \quad \underline{7}$

$\begin{array}{lllll}1 & 2 & 3 & 4 & 5\end{array}$

$1 \quad \underline{5} 1$

$\begin{array}{lllll}1 & 2 & 3 & 4 & 5\end{array}$

$\begin{array}{llll}6 & 7 & 1 & 1\end{array}$

$\begin{array}{rrrrr}1 & 2 & 3 & 4 & 5 \\ 1 & \underline{3} & \underline{4} & \underline{4} & \underline{3}\end{array}$

$\begin{array}{lllll}1 & 2 & 3 & 4 & 5 \\ 2 & \underline{5} & \underline{3} & \underline{3} & \underline{2}\end{array}$

$\begin{array}{lllll}1 & 2 & 3 & 4 & 5\end{array}$ 
96. I can't imagine myself witnessing.

97. I would feel free to talk to a close friend about my relationship with Christ.

98. When I think of witnessing I think of going out with groups on Sabbath afternoon.

99. I am afraid to share my faith with others.

100. Christian witness is essential to finishing God's work.

101. I would witness more if I knew how to go about it.

102. I am not the type to initiate any conversations on religion.

103. When I think of witness I have good feelings.

104. Witnessing is for those with outgoing personalities.

105. If given the chance I would give Bible studies to a non-Seventh-day Adventist.

106. Some jobs people hold don't really require the person to be a witness.

107. Witnessing should be left to those professionally trained to do it.

108. Witnessing to okay for those who like going door to door.

109. Witness really involves all of my life.

110. I find that my ideas on religion have a considerable influence on my views in other areas.

111. I would be proud to tell someone I am a Seventh-day Adventist.

112. Witnessing embarrasses me.

113. I like people too much to try to push my religion on them.

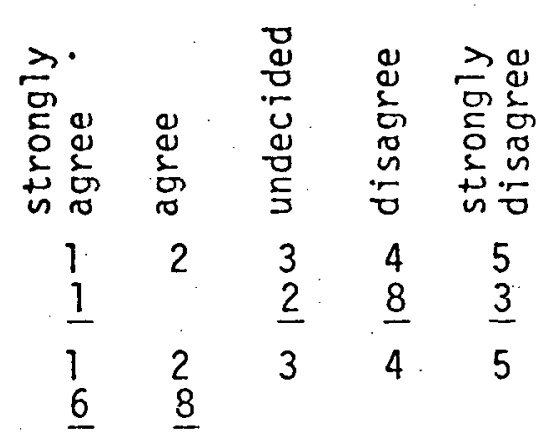

$\begin{array}{lllll}1 & 2 & 3 & 4 & 5 \\ & 1 & 2 & \underline{7} & \underline{4}\end{array}$

$\begin{array}{lllll}1 & 2 & 3 & 4 & 5\end{array}$

$\frac{1}{2} \quad \frac{3}{3} \quad \frac{6}{4} \quad \frac{4}{5}$

$\begin{array}{lllll}1 & 2 & 3 & 4 & 5\end{array}$

$9 \quad \underline{4} \quad \underline{1}$

$\begin{array}{lllll}1 & 2 & 3 & 4 & 5\end{array}$

$\begin{array}{lllll}2 & 6 & 2 & 3 & 1\end{array}$

$\begin{array}{lllll}1 & 2 & 3 & 4 & 5\end{array}$

$1 \quad \underline{2} \quad \underline{3} \quad \underline{6} \quad \underline{1}$

$\begin{array}{lllll}1 & 2 & 3 & 4 & 5\end{array}$

$1 \quad \underline{8} \quad \underline{3}$

$\begin{array}{lllll}1 & 2 & 3 & 4 & 5\end{array}$

$\underline{4} \quad \underline{3} \quad \underline{8}$

$\begin{array}{lllll}1 & 2 & 3 & 4 & 5 \\ 1 & 4 & 6 & \underline{3} & \end{array}$

$\begin{array}{lllll}1 & 2 & 3 & 4 & 5\end{array}$

$12 \frac{2}{3} \quad \frac{6}{4} \quad \frac{6}{5}$

$1 \quad \underline{5}$

$\begin{array}{lllll}1 & 2 & 3 & 4 & 5\end{array}$

$1 \quad \underline{4} \quad \underline{5} \quad \underline{4}$

$\begin{array}{lllll}1 & 2 & 3 & 4 & 5\end{array}$

I $\quad \underline{3} \quad \underline{3}$

$\begin{array}{lllll}1 & 2 & 3 & 4 & 5 \\ 8 & 5 & & 1 & \end{array}$

$\begin{array}{lllll}1 & 2 & 3 & 4 & 5\end{array}$

$\begin{array}{lllll}7 & \frac{5}{2} & \frac{2}{3} & 4 & 5\end{array}$

$\begin{array}{lllll}1 & \frac{1}{2} & \frac{2}{3} & \frac{7}{4} & 3 \\ 2 & 5 & 1 & 3 & 3\end{array}$

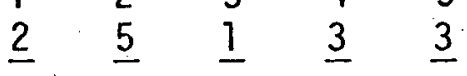


114. Daily Scripture study is not really vital to living a Christian life.

115. I would consider myself a worldly person.

116. Belief in God makes life on earth worthwhile.

117. Others who wanted to tell a dirty story wouldn't stop because I was in the group.

118. I like the positive feeling I have when I talk to someone about my religion.

119. I would not normally seek out opportunities to share my faith.

120. I shouid have more witnessing contacts with people of non-Seventh-day Adventist faith.

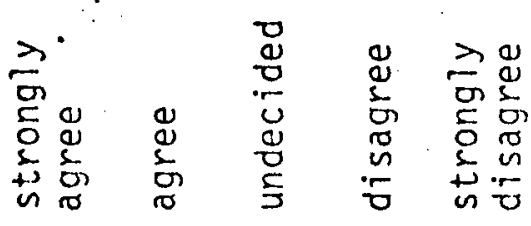

$\begin{array}{lllll}1 & 2 & 3 & 4 & 5\end{array}$

$1 \underline{5} \cdot \underline{8}$

$1 \cdot 2 \quad 3 \quad 4 \quad 5$

$12 \frac{2}{3} \quad \frac{5}{4} \quad \frac{8}{5}$

$11 \quad 3$

$\begin{array}{lllll}1 & 2 & 3 & 4 & 5 \\ 1 & 2 & 4 & \underline{5} & 2\end{array}$

$\begin{array}{lllll}1 & 2 & 3 & 4 & 5\end{array}$

$\underline{4} \quad \underline{10}$

$\begin{array}{lllll}1 & 2 & 3 & 4 & 5 \\ & 4 & \underline{4} & \underline{5} & \underline{1}\end{array}$

$\begin{array}{lllll}1 & 2 & 3 & 4 & 5 \\ 2 & 9 & & \underline{3} & \end{array}$ 
APPENDIX G

VERBATIM REPORT OF INTERVIEWS 
APPENDIX G

A condensed, lightly edited verbatim of taped interviews with a few Otsego church members and visitors. I tried not to be too leading in drawing some shy people out. The people had received no preparation or tutoring for the interviews, or in small church psychology.

It's Sabbath afternoon, March 15 at Dick Salisbury's home and we're just waiting for the ladies to get our potluck ready. I'm going to ask some of the folks here what they see in the smaller churches and in particular, what they see in their own little church here in Otsego that they find attracts them to the church and maybe they might even suggest something that they think may be improved.

June and Cliff have been coming along regularly to the church for quite a few months now. They are not baptized, technically I suppose they are not Seventh-day Adventists. They're studying and they are coming along fine in their Christian growth.

KERRY: Do you enjoy yourselves meeting with our little church, Cliff?

CLIFF: Yes, I do.

KERRY: Does.. well June's not here, we might talk to her later on about it as well. Can you tell me one thing that you find attracts you along to a small church in comparison perhaps with bigger churches that you've been to. Is it 
something about the smaller church you think that is more attractive than the bigger church, for a start?

CLIFF: Yes, it's being made part of the church and felt welcome there, and you can feel the love.

KERRY: So you think that by being small they can show more warmth to you than perhaps you'd find in a bigger church?

CLIFF: It's possible.

KERRY: Would you have any idea about what size church you'd find this would show up whereas you wouldn't in a bigger one? About what limit, any idea? Perhaps it doesn't always follow that way.

CLIFF: I don't think it follows. In the big churches I've been to I've never felt any warmth.

KERRY: No. What would you classify as big? About how many folk along in attendance?

CLIFF: I'd say about a hundred or more.

KERRY: Even a hundred or more you'd think starts to get a little bit colder than a smaller church? Anything else you can think of about the small church that makes you perhaps more at home or you enjoy more than perhaps in a bigger group? CLIFF: I don't know. I just can't say that I really enjoy it. KERRY: What about the church service itself? Actually sitting there in the church service, not just the people--talking with them afterwards or before the church service. Is there anything about the church service itself that is different and in anyway more attractive or less attractive 
for you than say a bigger group meeting?

CLIFF: I don't see much difference in the church service.

KERRY: So you think the ritual of the hymn singing and the prayers and the sermon is much the same in both groups?

CLIFF: Pretty much the same.

KERRY: So there's something about the fellowship in the smaller group?

CLIFF: Yes.

KERRY: What do you think--just in our potlucks or general talking together in the foyer of the church? When would you especially see the friendliness shown more? It's a bit difficult to put you on the spot like that but can you think when it shows up the most?

CLIFF: I'd say in the potluck dinners.

KERRY: When we have our potluck lunch each Sabbath. We're meeting this Sabbath in a home because we normally meet in the house alongside the church. Is that open today, Merv, or haven't we got our oil yet for our heating? No oil for heat. Okay. Louis, would you like to come over here. You're a Seventh-day Adventist and you're a member of-which church?

LOUIS: Pinedale.

KERRY: What size is the church you come from?

LOUIS: $\quad$ Right around 200.

KERRY: This was a combination of two congregations that were what size before that? 
LOUIS: About 125 for Gobles and around 75 I think for Bloomingdale.

KERRY: So now you end up with about a 200 congregation.

LOUIS: Right, about 200.

KERRY: How do you find what Cliff has been talking about. He says that outside the church service there seems to be more of a--how did you put it--sort of a warmth shown by the people in a smaller group which doesn't show up in... How do you feel in this matter of the small church and this warmth? Do you think this is an important thing or not in the church life?

LOUIS: I have been to big churches that have the warmth. Let's clarify that.

KERRY: What would you say about big, just estimating in your own mind "big"--50 member, 100, 150, 500--what would you say?

LOUIS: I have been to churches that had 3,000 members and were warm.

KERRY: Right. What was it about them that made them warm. Was it just the people or do you think they had an arrangement whereby they could show their warmth to people?

LOUIS: I think that first of all you're going to find that certain individuals will give an impression of warmth and caring and other people might care just as much but they don't show it in the same way. Most congregations that give an impression of warmth are those who have organized themselves in such a way that they'll meet you at the door, they will show an interest in you during the services, through speaking to you, like when you come in and sit down in Sabbath 
School they'll talk to you. They'll talk to you between the services, they talk to you after the services. They actually show that they care.

KERRY: So you think someone was organized to take the place of the welcomer in the church--that they knew it was their task to be like this, or do you think it was spontaneous?

LOUIS: You will find that some individuals will do this spontaneously but most people won't.

KERRY: In a big church do you think there is more need to have it organized otherwise no-one will do anything like that?

LOUIS: Right.

KERRY: Now, although perhaps it may have been organized do you think it came across to the people who are visitors as spontaneous? That you did really feel that you were we come?

LOUIS: I think that this is the important thing that if a large congregation is to choose someone or a group of individuals shall we say to actualiy do this they would have to be people that can do it spontaneously. If it's something that they're following, you know, rules and regulations, it is going to work out just like trying to follow the rules and regulations in salvation--it doesn't work.

KERRY: Right. It is going to be mechanical. The people are not going to feel warm. So it needs to be someone with a spiritual gift or talent that the Lord has sanctified in this area. I suppose it would be the gift of hospitality. 
LOUIS: And another thing about a small church is it's not as forma1. You might have a formal order of worship but it doesn't come across as being as formal.

KERRY: We just spoke before about the church service. What do you find different about the bigger church and the smaller church? First of all, is there anything more of an advantage for a small church than a large church as far as its order of service is concerned. You mention it's less formal. Is this an advantage or not, and in what way?

LOUIS: Scripture says that "the Lord loveth a cheerful giver" but I think he also loves a cheerful worshipper because giving is a part of worship and quite often you will find that the more formal a service becomes the less cheerful it becomes. I think that this is an important thing that there be a good deal of happiness in worship.

KERRY: Do you think this can show up in a less formal church service and a smaller church as you say, or a bigger church? Is it easier to take place in a smaller church?

LOUIS: I think it's easier to see the cheerfulness of worship in a smaller church, partly because seemingly everybody has something to do, and if you can keep a person busy you can keep them happy.

KERRY: Do you think that that's important for a church to have this--the people are happy and that they look happy, or that they enjoy worship and that they have something to do? LOUIS: If a person feels that what is happening is partly their 
responsibility they're going to be a whole lot happier. If they feel they are being shut out (and there are politics in larger churches which will shut certain individuals out), that when a person feels shut out that they are going to be less happy and it will show.

KERRY: That sounds like a big point. Now, outside the worship service, to the people as a whole, do you think there is an advantage in a church being big and operating in a bigger group, could they have more social opportunities for people, than in a small group? There are probably pros and cons with everything but what do you think outside the worship service?

LOUIS: As far as social is concerned, in the larger churches you will find that the social side of the congregation will be segregated more or less by age bracket. You will have the over 50 club, you will have the club that's aimed at parents, you will have the club that's aimed at the young marrieds, you will have the club for the teenagers, and so on.

KERRY: Do you think they would be able to operate in the small churches?

LOUIS: And in the small church you will find that they operate as an entire congregation and this, to me, is important because we are attempting to a certain extent in the large church to tear the family apart. Grandpa and Grandma go here, the folks go here, the young son who is just married goes here, and the teenage son goes here, and so on. Whereas in a 
small church everybody is pulling together and they are in effect uniting the family and this is an important thing and one which we as a people have got to look at even in larger churches.

KERRY: You mentioned the worship service. It doesn't bother you that perhaps we can't have the finesse and the fine timing and the good choirs and perhaps a good organ as you might find in a big church? That doesn't bother you in your worship? You would rather have the informality? You think that is an advantage? Not everyone has to agree with you, but for you personally, you feel that this is . . ?

LOUIS: Back in the 01d Testament, Scripture says "to obey is better than sacrifice" and to have love for God is the important thing. Okay so the timing's a little bit off. Maybe they have to use tapes like were used today for the hymn singing, but this is not to distract from the fact that we are there not to show off but to worship Jesus Christ. And I think that this is where we've got to look.

KERRY: And then you felt that outside the, or even perhaps within, the congregation, but particularly thinking of them as a group, they operate more as a collective entity, a family unit, rather than small groups oriented to the needs of the different age groups and the different interest groups of a big church.

LOUIS: With the emphasis that we have within the church on the family I think that the small church best exemplifies the 
family because of the way everybody has to pull together, otherwise things just don't get done.

KERRY: So you think as in a family group it should operate similarly in a church group--it should work together. I can see that that would be an advantage for the smaller church which is more tied together, with not so many different groups.

LOUIS: But this isn't to say that the family concept cannot be utilized within the large church, but you're going to have to have individuals that are willing to work at it.

KERRY: Yes, and to somehow tie it all together into a whole congregation.

LOUIS: Right.

KERRY: Which is perhaps not so easy to do.

LOUIS: Right.

KERRY: It is more difficult. Excuse me, Bonnie, I'd like to have a lady in here. Bill and Bonnie you come over here. Where are you from? Where's your membership at the moment?

BONNIE: Allegan.

KERRY: And what size is Allegan church?

BILL: About a hundred, I think.

KERRY: Louis has mentioned something from a Seventh-day Adventist point of view, though not that it probabiy makes very much difference because a church tends to be a church even in a different denomination. I want you to tell me what you think, perhaps Bonnie, from a lady's point of view. I guess you've been in bigger churches and you've been in 


\section{2}

small ones. Can you see any advantages? You can pick any situation you like in the church--the worship service, some of the clubs that operate in the church, the groups, the societies, or their social activity?

BONNIE: I really can't see that there are advantages. To me, I prefer the smaller church. I feel I get more out of the entire service. Our children do better in a smaller church, and we particularly changed churches because we were going to Pinedale. We changed to Allegan because it was a smaller church. Now because of my son's allegies we aga in changed to the Otsego church, and we are very pleased with it. We think it is a very nice and friendly church and the children, if given the choice of any church in the area that they would choose to go to--now they've been to Holland, they've been to Gobles--they. will choose Otsego.

KERRY: Can you narrow it down? What is it, then, I don't want you to say that we are lovely people here or that we've got blue eyes, or we've got green skin or we wear certain types of shoes. What is it, what is the characteristic that might apply perhaps to other churches not just to ours, that you think makes it that way? I know it's a bit difficult to analyze, but can you put it under a microscope and say what is it about it?

BONNIE: I think because it's a smaller church everybody has to work together as a group where the other churches tend to divide into smaller groups and not come together in a really functioning work group or work team. 
KERRY: Louis brought this point out. He noticed that too. You see it's easier to work together as--he said it's more like a family. Would you agree with that sort of a summary? BILL: Yes. If you want to get something done you almost have to get the cooperation of everybody. In the smaller church even a very simple task like whether the piano is played or not--I mean everybody works together at it or it just isn't done.

KERRY: Now it is possible for factions even to come in a small group which is disastrous. A big church can handle that easier perhaps. But if that isn't there, if they operate together as one, you think it is easier to have this sort of a group inter-relationship? How does this show up to a visitor? Do you think they can sense that? Does it show up in some different effect that the visitor can notice?

BONNIE: I think as soon as you walk in the church door you can tell just by the way things are going. You can tell whether there is stress there or you can tell if there isn't much stress there. They're all in an organization working together for the love of Jesus Christ. I think as soon as you enter the church that you can tell that.

BILL: I think she is especially perceptive. I'm not near as perceptive.

KERRY: You mean picking it up in the atmosphere of the place. Maybe that is woman's intuition which us males don't have so much.

BILL: It could be. It's possible. 
KERRY: Well what about you, Bill. Now your wife's expressed her feeling. Do you feel the same sort of thing?

BILL: Yes I do.

KERRY: Have you been in a big church? I mean a big congregation.

BILL: I was in a Pennsylvania Avenue church in Washington, D.C. That's 300 members.

KERRY: By some people's category that's not a large church, but often by ours it is fairly large. Did you go into some others where you were welcome and you felt welcome? Not so easy to put you on the spot I suppose.

BILL: I haven't switched around many churches, although I have. sensed warmness in some larger churches. Sometimes I did in the Pennsylvania Avenue church.

KERRY: From what you folks are saying then, you'd say it embraces not only the worship service, but embraces the welcome of the folk coming in, even Sabbath School, is that right? And even the potlucks and the social activities? You think they do all these as one? And they feel more as one?

BILL \& BONNIE: Yes.

KERRY: Does the worship service come over to you better because of this or not? Can you enjoy sitting in a big church and enjoy it as being more precise and more professional?

BONNIE: No.

KERRY: You think there's something more important then?

BONNIE: Yes, I think definitely there is.

KERRY: Which is what? Can you just nail it as we finish because lunch is ready. 
BONNIE: I really can't put my finger on exactly what it is. To me it doesn't matter who the speaker is, whether he's a. farmer from the woods, as long as he has the message of Jesus Christ. Or if it is a preacher with seven degrees, if he has a message of Jesus Christ in his heart, then it's going to come over that way.

KERRY: And you think this comes through better in a smaller, more intimate group?

BONNIE: I don't think it has to. I think it usually does, but I don't think it has to.

KERRY: So the preacher sort of takes on the same atmosphere of the church--more a friendly, close person, puting him in closer touch, you think, with the people?

BONNIE: I think if, when you're in a group that gives you a negative feeling you tend to retreat a little bit. If you're in a happier atmosphere you're more outgoing.

KERRY: So that's part of the sermon reception too. Thank you Bonnie and Bill.

Today is about three weeks later than our previous discussion with some of the folk in our small church. This day is Sabbath, April 5, 1980, and I'd like to just briefly have a chat with Chuck and Donna who have not been Adventists all that long. We' 11 let them perhaps tell us more about how they came into our small church, and some of the reasons why, what they see, how they look at the church, what they think about it. We'll ask them. 
KERRY: Well, Chuck and Donna. You haven't been Adventists all your life. How long have you been baptized?

CHUCK: It's been a year now.

KERRY: What was it that brought you into the church? What influences do you think brought you along?

CHUCK: Well, there seemed to be quite a few. Meeting different Adventists before we came was part of it.

KERRY: You'd aTready met some Adventists? Who were they?

CHUCK: Wilma Faylor and Betty Clark.

KERRY: Is Betty your landlady? Wilma is from our own church here, doing a good work studying with folk, sharing the Bible. We'll have a chat with Wilma later on. So now she began to study with you and you were impressed that what she was saying was right? Were you already interested in spiritual things?

CHUCK: It was pretty new, but I was already interested in spiritual things anyway. Some things she was telling us seemed to be really new and contradicted a lot of things I always believed.

KERRY: So it was the attraction of some of the things that she was telling you that had you interested? That the Adventists might be teaching what the actual Bible was saying? Was that it? Can you explain it Donna?

DONNA: We were taking Bible studies from a different church and the Adventist church at the same time and they both contradicted each other so much that, you know, we found...

KERRY: You wanted to find out what was right and what was not 
because they seemed to conflict. And Wilma seemed to be able to explain it fairly well from the Bible for you?

CHUCK: Pretty much. We studied ourselves. We got, you know, one side of the story, and the other side, and kind of dug into the Bible for ourselves.

KERRY: So it was really all searching and seeking, and I guess you were praying at this time were you, for guidance and help? And you'd been reading the Bible and sort of longing to find from the Lord what was truth?

CHUCK: Aha. We stayed up pretty late at night for a couple of weeks it was. I was especially. Donna was beside me, studying to find out some of the new things, we were searching.

KERRY: So that must have been going some months before you actually came along to church, I suppose. Wilma invited you along to church, did she? Or you asked to come, or how did you actually get along?

DONNA: Our landlady--we went with her a couple of times.

KERRY: Now in your past life, not only amongst say the Adventist church and I don't know how much church attendance you have engaged in, but had you visited other churches very much?

DONNA: Yes.

KERRY: Some are big some are small. This project that I' $m$ doing particularly involves the smaller church and we want to get at the dynamics that make a small church go, how effective it is, maybe realize some of its weaknesses. But there does 
seem to be some things about a small church that is attractive. You're now members of a church here at Otsego, which is fairly small. How do you look at it in comparison with meeting in a big church--going along and attending worship in a big church? Do you see any difference at all between the two?

CHUCK: Yes. As I walk into a big one it seems like there's so many people. To me it seems like you're not really known-we11 when you first come into a church you feel a little uneasy, kind of standing out in the church, especially in the smaller one. When we first came in here, there were very few people and everybody knew we were not regular members .

KERRY: So you could go into a bigger church and sort of be swallowed up there? And maybe not be so noticeable, whereas. in the smaller church you stick out more--you're a stranger.

CHUCK: It seems like once you're noticed--well of course you are when you walk in the door, but...

KERRY: Well what fact made you feel better, if you did feel better, in that circumstance? Did anything make you feel at all comfortable or did you feel uncomfortable? Was there anything or any person that made you feel that you had some attachment to that building and that group?

CHUCK: Maybe after the first time. It was the first time we came here and we thought well perhaps we will feel a little easier next time when people had met us.

KERRY: Did the fact that you knew Wilma make you feel that there 
was at least someone that knew you?

CHUCK AND DONNA: That helps.

KERRY: Say that you just walked off the street into a little church. You didn't know anyone: Now, how would you feel. then?

DONNA: You'd feel kinda strange.

CHUCK: It would be hard to come into it, I think, but once you're there then it's easier to come back.

KERRY: It would be difficult, but until you are surrounded by people and they show themselves friendly and you have friends, it would be difficult.

CHUCK: But once you have in a small church, I know people open up easier. There's not that many.

KERRY: After a few weeks of coming along did you begin to feel a little easier?

CHUCK: Oh yes.

KERRY: Can you say why you felt a bit better, a bit easier?

cHuck: Well I think it was just when you first come, you know, meeting everybody and being a little accepted, I guess.

KERRY: So it was getting to know people?

CHUCK: It's breaking the ice I guess just the first time. After that it was pretty easy to come--it wasn't a hard thing to do anymore.

KERRY: The first time's the hardest, I know. I've gone through it myself.

CHUCK: We felt pretty welcome.

KERRY: Now it would be easy to break the ice in a big church, 
you've expressed that. I probably feel that way. You can slip in there and no one knows you. You can also slip out again and no one knows you've gone. But what about the other part? In the small church you are noticed which has got its disadvantage in that you feel like you're sticking out like a sore thumb. You're different, you're new. At the same time people do come up because they do notice you and can make you feel welcome. Do you think maybe it may have a disadvantage in that it makes a person feel uneasy for the first time, but it may be more helpful later on because they now have a chance to notice you and make friends with you? Whereas in a big church you might be just swallowed up for weeks on end and no one notice you? Have you ever noticed that at all in a church? Maybe you haven't gone along enough to be able to express that that's so or not.

CHUCK: The church seems to be so small and you really want more people coming in, and when you do see somebody coming in it seems like you work a little bit harder.

KERRY: So you think the small church has got a bit of a drive to bring folk in, to make them feel welcome?

CHUCK: I think of myself, when someone comes in the door... KERRY: You like to see visitors coming?

CHUCH: It's such a good thing to see somebody new in this small church.

KERRY: So the small church is perhaps more aware of wanting people there and so that will have its effect upon making them 
more friendly otherwise they might just stay in their shell and not come out.

KERRY: What are some of the disadvantages in our small church?

CHUCK: We11, there's not much activity.

KERRY: So there's not much activity for the young people particularly?

CHUCK: Or even in the church.

KERRY: How do you mean that?

CHUCK: The people are spread out so far.

KERRY: There's more space between people in the smaller church? CHUCK: Aha.

KERRY: So this can drop the unified atmosphere do you think, of the church?

CHUCK: It seems to be that every Sabbath everybody--well we don't see each other through the week. We don't have any prayer meeting or anything. I don't know why but... KERRY: That's something that's racking isn't it?

CHUCK: There's the disadvantage in such a small church that if a few people don't make it to a meeting or whatever there's really not many people there. Maybe none.

KERRY: Donna, do you see any advantages in say the smaller church over the bigger church at all? We know that we don't have an organ here, we have got to sometimes get along without a piano whereas in a big church they might have both a choir and an organ.

DONNA: We11, I was just going to say that I think the advantages that the little church has is that it feels like you can 
have more closeness with God when you're in the church. Closeness really more than--if there's so many people there, where there's so much going on you can hardly keep track of everything.

KERRY: What about the fellowship in a church? Is it closer do you think in a smaller one than a bigger one? There's less of it maybe, less social get-togethers. And that's a problem.

DONNA: I think that when they do have it, they're pretty close to one another.

KERRY: Thank you, you've both been a help and I hope that we've got something out of here that will help our small church.

This is Sabbath, 17 May and I am talking with Margaret Payne. Margaret's been bringing along a friend to our small church.

KERRY: Sister Payne, I think you were here when the Otsego Church re-formed again. What year was it closed? It was in the early 70 s wasn't it?

MARGARET: I really don't know.

KERRY: At that time you were going to Kalamazoo, is that right?

MARGARET: Yes, I was going to Kalamazoo Church.

KERRY: Who was going with you?

MARGARET: My daughter, Carol.

KERRY: What made you want to come and join a little church that had been pronounced defunct and dead, and then they got it going again? How did it take place, how come that this little church began again? 
MARGARET: We11 Carol wanted to change over and...

KERRY: Was the church started here at that stage?

MARGARET: They were just beginning to start it. They had closed it down and they were getting ready to reorganize it.

KERRY: Who was organizing the beginning of it again? Was it David Yancey?

MARGARET: Yes, David Yancey and . .

KERRY: He had someone else helping him? What did he do, because there's not very many people living in Otsego? Did he visit these people?

MARGARET: He went around to all the homes that were in the district of Plainwell and Otsego and anywhere near here. There were quite a few who joined at that time, then some of them went back to Kalamazoo Church instead of staying. They decided they wanted to go back to Kalamazoo.

KERRY: So some of them decided they wanted to come here and get it going again and David visited these people that lived here. At that time they were going to Kalamazoo were they?

MARGARET: Yes.

KERRY: Did he visit you?

MARGARET: Yes.

KERRY: And asked you?

MARGARET: Do I know people who wanted to change, and Carol wanted to change very definitely.

KERRY: Now that's strange because she would have been at that age, what, twelve or thirteen? 
MARGARET: No, she would have been about fifteen or sixteen.

KERRY: Well she would have had her other friends there at Kalamazoo--quite a big church. Wouldn't these have been an attraction to keep her there?

MARGARET: I don't know, evidently not enough, because she wanted to change.

KERRY: Well now what do you think it was then?

MARGARET: I think it was spiritual problems, it's more spiritual here than it was in a larger church.

KERRY: There's something about this small church that was more spiritual? Do you think it would have been the preacher, was he different, or was it the fact that there was something about the people that gathered here? What raised up the spiritual level do you think?

MARGARET: I really don't know.

KERRY: You just can't put your finger on it?

MARGARET: No.

KERRY: You did visit here I guess, and she must have got the impression that it was that way, did she?

MARGARET: No, we hadn't visited here before until they started to reopen it and they went around to all the different members and asked them, the Kalamazoo Church and the Allegan Church--where it was closest to the Otsego Church. They went around to visit them, and she just wanted to come, that was all.

KERRY: And at that stage how many other people in her age group were here? 
MARGARET: Well there were the Salisburys, Rick was her age--a little bit younger. And there was, oh, there was a few others I can't remember right now. When Elder Ludowici was here his family was here...

MARGARET: Yes.

KERRY: That's interesting. And you feel that it was probably because she felt it was more spiritual? Do you think it was something about the fact that it was a small group, that they knew one another, that there was more love shown between the people?

MARGARET: I think so. Like a family group.

KERRY: Perhaps she felt isolated up there, or less welcome amongst people in the big church?

MARGARET: Could be.

KERRY: Anyway, maybe I will have a chance to talk to Carol. I might call and have a chat to her and Dale personally down in Berrien.

MARGARET: Well when she first started she was still in church school in Kalamazoo. Then she went to Cedar Lake for two years, but she still liked Otsego better than she did Kalamazoo.

KERRY: You weren't actually going here when the Otsego Church was in operation before it closed?

MARGARET: No.

KERRY: Had you ever visited here before?

MARGARET: The last time I visited was when Carol was a baby and I pushed her in a buggy over here to the ... . I had Nancy, and Carol was just a baby and we walked over because 
my husband had to work that day. We didn!t have any car to get into Kalamazoo so I put her in the buggy and we came over here to church. So that was the only time she'd ever been here before she decided she wanted . . . .

KERRY: Have you been an Adventist all of your life, or most of your life?

MARGARET: Mm, most of my life.

KERRY: What about you yourself, how do you feel? Do you ever look back now on ail those years you went to Kalamazoo, the relationship you had with others? How do you feel that compares with our small church here? Which do you personally prefer?

MARGARET: Well, I like both of them. I still have partialities for Kalamazoo.

KERRY: You've got friends there I suppose.

MARGARET: Yes.

KERRY: What is it about it that attracts you there?

MARGARET: My friends.

KERRY: What about the climate--the feeling in the church? As you go into church the folk greet you. of course you know a fairly large number of people there so I suppose they would make you feel welcome?

MARGARET: I like it in Kalamazoo, but Carol liked it here so we changed and so I'll probably stay here now. I really like it here though.

KERRY: What is it about this church that you like then? MARGARET: I like the friendiiness and it is like one big family. 
KERRY: So, most of even the ex-Kalamazoo group might say that it is really the friends that you know that attracts you there, and here it's the folks you know here. So it's the personal attraction between people and friends that really is the big thing.

MARGARET: Yes.

KERRY: I guess that really is the important thing in a church whatever it is.

MARGARET: I think so. Sometimes it's the minister too that has a lot to do with it, and we had different ministers in Kalamazoo that I really did enjoy but now I don't even really know the minister in Kalamazoo any more so it wouldn' $t$ be that drawing point.

KERRY: No.

MARGARET: But I still miss the members there.

KERRY: Yes, because you knew them for so long.

MARGARET: I'm still in contact with quite a few of them too.

KERRY: Yes, although they are still going there and you're still coming here?' For some time now you've been bringing a lady along to church--Mary. How did you get involved with her?

MARGARET: We11, we've been friends for a number of years. She's kind of a lonely lady. She asked one time if anybody could go to my church that wanted to, and I said why yes, and she wanted to know if she courd go with me and I said, why sure you can come with me. And so I bring her along. 
She's religious at heart, she doesn't really belong to any church, I don't think.

KERRY: I see. But she's fairly shy and quiet, but perhaps I might get her to tell a little of her story.

The 7 th June and we want to talk to Merv and Wilma about their relationship with our small church to find out some of their attitudes.

KERRY: What brought you along here, Merv and Wilma, to Otsego? It's only a small church. About how long ago did you start coming here? That's you, Merv.

MERV: Well, the first time I started church here was about ' 73. I was attending the First Baptist Church here in Otsego, but I had had some background with the Seventh-day Adventists twenty years ago or more. As I was listening to sermons preached by the Baptist minister I was finding discrepancies in his sermon in relation to the Adventist beliefs and I felt that I was going to have to, well, get back into the truth if I was going to go to church. So as a result of that I started attending this church, even though I live some twenty-five miles away and I fell absolutely in love with the people here. It's more than just a church, it's a family of God here where everybody loves one another. Everybody knows each other not by face, but by first name, and that's a great comfort to know that when you come to church here you're stepping right into your family. 
KERRY: So there was the aspect of the message. That seemed to convict you, that there was truths there that you weren' $t$. hearing in another church. And then the other part that impressed you was the fellowship, did you say?

MERV: The family.

KERRY: The feeling that you are one of the group, that they sort of embrace you. Did you feel at all that you were an outsider, that you were a stranger coming in there, or what attitude did they have towards you when you came along?

MERV: The first time I came here I never felt like a stranger. The very first day you're part of the family right then and they say here they have a little motto--'you're a guest the first time you come but from then on you're part of the family.'

KERRY: And Wilma, now you've been an Adventist for longer than Merv, haven't you? Most of your life? What's your past history covered? Have you been mainly attending large churches, say 300 and above, 400 and above, or mainly smal1 churches, or what was it that brought you here to 0tsego? WILMA: We11, I had been attending and was raised in an Adventist church of a thousand membership most of my life, and when Merv and. I were married, almost four years ago, we attended the Kalamazoo church, which is closer to us, and it's over 300 members. And we felt like guests there every time we went. They were glad to see us and they have some beautiful people there, but the number is too great, so we visited here a few times and it's like this was coming home. 
It wasn't like visiting it was just coming home to the family. And right away, I always felt when we were in a larger church that you just kind of get lost in the shuffle. There's certain people that do many of the jobs and they're very well equipped to do them, but some of the other people don't have a chance to use some of their talents. And coming to a small church they right away put us to work and that helped, I think, in feeling we are part of the family, that we're needed somewhere. And so it wasn't any question, we didn't even have to discuss that we were going to come here and have our membership because we can really see a need here.

KERRY: Had you had any experience before in a small church such . as ours--which is quite small really, below fifty?

WILMA: Well, when I was very young, from when I can't remember until I was about three, my folks and I attended one that was about thirty, or forty members, it was very small too. And that was the seed that was planted in my mind when I started to come to... And, yes, I've visited and been involved with smaller churches under a hundred membership in past years. I always feel more a part of a smaller group.

KERRY: Others have expressed this, in Kalamazoo, they've enjoyed the church, they've still got lots of friends there, but you say now, there was something there that didn.'t involve you. You were not involved in things directly, was that it? Was it the fact that you couldn't know everyone intimately, or when you went along there did you mingle in just a small 
cel1, one small group of people? Can you put your finger on it? It may not be easy to express.

MERV: Yes, that's quite easy to express. Before we were married I attended the Adventist Church in Kalamazoo for quite a few months. I took Bible studies from Elder Coball, who was the pastor there at the time, and was baptized into the Kalamazoo Church. So even though I did not know all of the members, or most of the members, they should have at least known me from the experience there. And after we were married we were talking with a lady in the foyer one day after church, and had quite a discussion with her and everything. The very next Sabbath this lady didn't even know us. She didn't know who we were or where we came from, or anything about us. She walked up to us and wanted to know if we were visiting, and I looked at her and I thought this can't be real. This can't be really happening because almost in the same spot that she was asking us if we were visiting, we had held a discussion with her for several minutes the week before.

KERRY: So you don't think it was just her bad memory, you think it was the fact that there was so many people that it was almost a mechanical welcome, but it didn't stick enough to last one week?

MERV: Right, and there were other experiences similar to that but not quite as obvious as that one.

WILMA: Well, in fact, I had gone to school with her daughters in the Battle Creek Academy and I had known her for years myself 
before from the Tabernacle, and she didn't even know me after I explained who I was the week before: I thought, wow, this is unreal.

KERRY: So you think that when the group gets to that stage where it's too big for you to regularly circulate amongst the people, you become unattached to other people in the congregation? You become unfamiliar with them, whereas here in the group setting which is fairly small, you know everyone regularly, so you never forget them, is that what you are saying?

WILMA: Right.

MERV: Well my personal opinion, and it's strictly my opinion, is that when our churches reach a membership of two hundred, that's a hundred too many and they should split into two churches and try to keep the membership somewhere around a hundred.

KERRY: And you think for this reason you're talking about--so everyone knows everyone else--you can relate to everyone else, and there's no one that could be coming along and no one know all about them, and show them a warm welcome. Why do you think this doesn't take place in a group that gets too big?

MERV: The Adventist Church is more than just a church, it's more than just a group of people that come and worship God. We are a family and we should be as close as if we were blood relatives, which, with only having one Father, we should be blood relatives. And we should treat each other exactly that 


\section{3}

way, and when you're dealing with churches with memberships of $500,1000,2000$, this is physically impossible to do. You can attend that church all of your life and you will never get to the stage when you know everybody. KERRY: So you felt also, you mentioned, that it was the fact of being involved in doing things in the church, and you felt that in the big church you're sort of lost, the talents and the abilities you had were not used at all, or very little, and you felt that in the smaller group you could be useful? Does this make you feel better as a contributor towards the group or feel better in that you are carrying out the Lord's work more? You felt more satisfaction, did you, in being involved?

WILMA: Well I did, very definitely, because some people don't really know the talents that they have unless they have the opportunity. And each one of us has gifts of the Spirit and how are we to know if we're lost in a large shuffle and in a larger church where everyone isn't able to participate.

KERRY: So you think the smaller group is better able to use the gifts and the talents in it than the big church where they can be sort of overwhelmed by the numbers?

WILMA: Right, very definitely.

KERRY: We've already taken a study here on Spiritual Gifts and even before we took that study you, Wilma, seemed to be showing talent or a gift from the Lord in the area of contacting others and studying with them. You've been working on this now, for how long is it? Two years? 
WILMA: I guess it will be about two years now, yes.

KERRY: And Merv, you're involved in some leadership work in the church. You've been in Lay Activities, haven't you, too? And doing deacon's work, and other items in the church.

MERV: Lay Activities, some Sabbath School Superintendent, some teaching, and deacon, yes.

WILMA: And a very good supporter.

KERRY: And he's supporting you in your work too, in visiting folk which takes a lot of your time.

WILMA: Very definitely.

KERRY: Now looking at the work you're doing. You're doing it from a base in this little church here, and earlier we were talking about some folk that you're studying with who, to your disappointment in a way, have chosen to be baptized in another church, but they're still having studies with you. So you realize from that that you are also doing a work for the Lord in a broader sphere than just representing this church. You're really bringing Christ to others and if some unfortunately, don't see their way to join the Adventist Church, you are at least doing a work that is bringing them along the way, and perhaps this is one step in that process and hopefully we will see them in the church. But still, outside that, you're still circulating with a base in this church. Now how does that make you feel knowing that these people, when they do come along, will be coming along to worship here in this church, in this little company? How would it be compared with you having a base in a big church? 
Do you think you'd feel better to bring your contacts along to worship in a big church, or to come along and worship in a little church? And if you see a difference there, which would you feel better about, could you express that? Put yourself in the two situations. One where you are now, where you can bring along folk like Cliff and June, and Donna and Chuck. Then if you were working say out of Kalamazoo or a church of a thousand members or five hundred. Do you see a difference in being able to bring folk there, and do you think this would effect your contacts? In what way?

WILMA: Well I'll share a little bit. I have been talking to another Bible worker from a larger church. He has brought people into this larger church, and he says so many times in a larger church it seems like the members get involved with how they are, how they look, and your status in society. This seems to be a problem with a woman that he brought into the church. The girl wears glasses, she's over-weight, she's not real neat, she has some things to learn. So he used to go out of his way to make sure that she feels welcome because some of the church members are not very susceptible to her. Well with my studying, and I don't mean this to put anybody down, with my church here, I've never felt that way because I had a young couple that did not even have a dress for the girl to wear. I told them, it doesn't matter what you look like, we' 11 love you just the way you are. And I felt very confident in that fact, and when they did come, in fact the first time I had to go and get them and 
bring them to church, the people just welcomed them. They could have been clothed in the most expensive clothes and wearing diamonds and everything else and they would have been the same. They just came in clean blue jeans, because that's all they had. Everybody just loved them right in and I knew this would happen. And this is one reason why I really like a small church.

KERRY: That's interesting.

MERV: It was quite ironic on that particular day because this couple were really concerned about their clothing and they were reluctant to come. But the Lord also knows the situation before it even happens. Dick Salisbury, was our Sabbath School Superintendent this particular day that they were to arrive, and the Lord gave him a message to bring before the congregation before the Sabbath School Lesson. The message that he brought had to deal with clothing--that it wasn't all that important, and that what was on the in side was more important than what was on the outside. After church was over this couple came to Wilma and said, "You said something to them about our clothes." Wilma said, "I didn't say anything."

WILMA: I didn't say anything to anybody. I don't even know if I mentioned it to my husband, because they were very very concerned about their clothes and I said, "Look it's not going to make any difference to the people in the church I represent because they' 11 love you anyway." And they saw that it actually was exactly like I said--they have mentioned 
that several times, afterwards. They said, "We couldn't believe everything you told us about your church and how they love people right in, but it really is true."

KERRY: That's interesting, isn't it? A true family should be like that--accept people. In a family situation the kids come home from school a]l dirty, grubby, and messy, and you accept them in the family, no matter if they are dirty and have fallen over and ripped their jeans. That's got little to do with them being accepted--they're still loved and wanted.

MERV: In the larger churches and you find this in probably every large church in the nation, there are certain groups of people who just stay more or less to themselves. That's not in this church. There's no cliques in this church. If there is, there's one, and that's the entire church.

KERRY: I think you're right there. Now, will you just give us a run down of how many folk you've been visiting, how many folk have come along and have been baptized because of the work you've been doing--the personal work.

WILMA: Well, it's kind of hard to narrow it down because we as a family are interested in health also and this seems to open doors to meet many people, even outside of the church, in a health angle, and invariably we've had a chance to share our faith. One young lady came to ask about our health products and before we even got started on that we sat down and talked for at least twenty minutes on the second coming of Christ-and we had never met before. So to narrow it down as to how 


\section{8}

many visits--we're having many every day. Through the church, I think I've got about six on a study basis, with about four names that I need to contact yet. It seems the days are just not long enough. And now this one young couple that I've mentioned, they had been living together for four years, and they decided through the studies that this was not right, so we married them in the church and then we followed up by baptism and it was just like a family-wedding and everything.

KERRY: Yes, once they were married they looked upon this as their church home and their family, didn't they? I can remember how they came along, and their attitude towards the church was so strong after they were married here.

WILMA: And everybody looked upon them as just part of the family. Now I've had another young couple that are coming and I've studied with him over a year and he's taken his stand. I've only been studying with her since they're been married-about ten months now. I feel very strongly that she will make her stand in the near future, but I have not had the privilege of studying with her as long. I have other couples that are making major decisions for the Lord. Two couples have been baptised, but not as members into our church which has been, well, a little bit disappointing to me, but yet, I shouldn't worry about these things because we don't know how the Lord's going to be using them in another church--they may be very strong in another church. I'm still studying with one couple and still in contact with others that I have 
not been studying with on a regular basis any more, but I'm still in contact with them, and they are making fantastic decisions and really sharing their faith with many other people.

KERRY: That's wonderful. You've had three folk baptised into the church over the last twelve months or so?

WILMA: Yes, three.

KERRY: And June's coming along very well. And there are other folk just on the outside who haven't made that choice yet, to come along and worship with us.

WILMA: All we can do is what we feel the Lord want us to do, and then we're not to worry after we have presented the truth to someone because that's really taking on the Lord's work. It's no use starting to worry about how we presented it or why they're not accepting things, because they' 11 come along when the Lord feels like the time is ready.

KERRY: We11, I gather from what you say that you've got no hangups or worries about bringing your contacts along to our little church. There's no worries in your mind that they're going to get abused or mocked at or fingers pointed at them, or not made weicome? You've got no worries there?

WILMA: Absolutely none. Just absolutely none, because this one. couple that came in blue jeans for the longest time because that's the only thing they had, and then this new couple-I think she's only got a couple of dresses or she's usually wearing slacks to church and it absolutely doesn't make any difference to anyone. 
KERRY: They know they're welcome and they're loved here?

HILMA: That's right.

KERRY: Keep up the good work, both of you, in the church and thank you for helping us.

WILMA: You're welcome.

It's Thursday night, June 12, and I'm at Berrien Springs, the home of Carol and Dale Barnhurst. Carol's mother mentioned on the other side of this tape that she was fairly instrumental in both her and her mother going to Otsego, some years ago now, and so we wanted to chat to Carol to see exactly what it was about changing over from the church where she was going before, to Otsego, and what there was about the little church there that attracted her. If she was disappointed after she went for a while, or what it was that held her when she went there. We'll see if we can find out a little bit from her.

KERRY: Carol, around about when was it that you were going to the other church and where was it that you were going?

CAROL: Well I was going to Kalamazoo. I wasn't really happy with it because it was too big.

KERRY: How long ago would that have been?

CAROL: I don't know, whenever I was in the seventh grade.

KERRY: The seventh grade. Now, when would that have been?

CAROL: I'm twenty-one now--almost ten years ago.

KERRY: You were going to Kalamazoo at the time?

CAROL: Right, and I was going to school in Kalamazoo.

KERRY: Church school? 
CAROL: Church school, yes. But I just didn't fit in a lot of the cliques there.

KERRY: When in church school you must have had other school friends that you were going to school with that you knew who must have been going to the church too.

CAROL: Some were and some weren't. Some went to other churches. There was one girl, she went to Three Rivers, another girl was going to the black church in Kalamazoo, and they were my two best friends. So, they weren't at church that much anyway. And so, one time they were having evangelistic meetings out in Otsego and I just talked Mum into going out there. I was really shocked, I didn't know there were any churches that small, I'd always gone to Kalamazoo.

KERRY: What size is Kalamazoo?

CAROL: I don't know. Probably at that time about 200 to 300 somewhere. Two hundred or over. I just didn't realize there were such small churches because it was even smaller then than it is now.

KERRY: So an evangelist ran the meetings, did he? or the pastor? CAROL: No, they were students, or seminary students I think they were from Andrews. And it wasn't ton long after that the church started out and I talked Mum into going.

KERRY: It was closed at this time was it?

CAROL: It was closed at that time, yes.

KERRY: And they held the meetings in the church?

CAROL: I think it was.

KERRY: When did they hold them? Saturday night, or Sunday night? 
CAROL: No, they were every night.

KERRY: Every night. For a week, two weeks, three?

CAROL: I'm not sure.

KERRY: I see, and then they began the church up after that?

CAROL: It seems like it. I don't remember for sure. I remember they had meetings there. I'm not sure if they closed down after that or it was already closed down then. I almost think it closed down immediately after that because it went poorly or something. And then about a few years later we started going there regularly after it started up again.

KERRY: You can't remember exactly but anyway, you were fairly foremost in wanting to go there?

CAROL: Yes, my Mum had gone to Kalamazoo all her life practically and all her friends are in Kalamazoo.

KERRY: She mentioned that.

CAROL: She really didn't want to go, but I think she went because I wanted to go and she knew that I wasn't really happy at Kalamazoo Church at all.

KERRY: So you went along there to Otsego. How many people did you find when you went there?

CAROL: Probably about thirty at the most. I was the eldest kid, and it was kind of an interesting situation.

KERRY: Well were you disappointed once you went there?

CAROL: No, I wasn't.

KERRY: With this small group with you the oldest?

CAROL: No, it was fun because I got to be with the other kids and help them. If they had problems they would come and talk 
to me about their problems. It was really nice. I got to really help the kids and it was something that I needed, to help somebody else and I couldn't do that at Kalamazoo.

KERRY: Did you feel that you weren't needed or you weren't used, or people didn't know you were there, or if you weren't there: no one would have noticed, what was it?

CAROL: All of those.

KERRY: I don't want to put words in your mouth.

CAROL: It was all of those. I had about three friends that were in Kalamazoo all the time and I missed those three friends.

KERRY: You'd been going in that community for all that time and you'd really only got to know, what, two or three, that you were close to?

CAROL: Right.

KERRY: I see. There were no others in your age group, or there were and you didn't mix with them very well? What was it?

CAROL: Well there were some that were older and some that were younger. My birthday fell in such a place that I was always the youngest one in the department, and if I was promoted with my class, I was the youngest one, and frequently they didn't want to promote me because I was younger, because my birthday came at the wrong time for promotion time, or something. It was something really dumb, so I always felt awkward in whatever group I went into, and like I really didn't belong there. Most of the kids were older.

KERRY: So you made that break and went to otsego. But there you didn't find too many people, I wouldn't have thought, in 
your own age group. What were you, twelve then, or something?

CAROL: Yes, I was probabiy about eleven or twelve. But they were all friendly and we all got along very well.

KERRY: So you think it was the climate and the atmosphere of the place that did it?

CAROL: Definitely. I was accepted there where I hadn't been at Kalamazoo. I knew people cared if I was at church, and later on that was the one thing that kept me in the church because I almost lost the church for a while. And the only reason I kept coming was because I knew the people expected to see me there. And that was really important.

KERRY: Do you think that this is common with other young people too?

CAROL: I don't know.

KERRY: Or maybe it's more common than we realize and we don't perhaps help this along? It's hard to say, isn't it?

CAROL: I really don't know.

KERRY: It was true in your case anyway?

CAROL: Right.

KERRY: So then you were there up until, well, you were going there when we came there so you've been going for some time.

CAROL: I changed my membership after Dale and I got married.

KERRY: To down here?

CAROL: No. We go to a small church down here--Chickaming.

KERRY: And how many members there?

CAROL: How many, Hun? About sixty on the books, and about thirty 
actual active members.

KERRY: - So now how do you feel down at Chickamina?

CAROL: I love it.

KERRY: Once again you're in a small group.

CAROL: YeS.

KERRY: Do you know most of the folk there?

CAROL: Oh yes, most of them.

KERRY: So you feel that you're, what, sort of in a family?

CAROL: Somewhat.

KERRY: And you feel that you are getting used there in that your talents or gifts are being put to use--too much is that it?

CAROL: That's for sure. The second week we were there we got pulled into Pathfinders. We hadn't even joined the church yet and we were told that we were needed in Pathfinders, so . . About three months later I was told they needed a kindergarten teacher and now they need a V.B.S. assistant leader.

KERRY: I see.

CAROL: Any more would be too much.

KERRY: So you're enjoying your little church experience again.

CAROL: Definitely. It's very similar to Otsego in its format and the attitude of the people.

KERRY: Do you feel that you have enough activities there to keep a young person, a married person like you and Dale, involved? Enough social activities?

CAROL: Well, social activities are so-so, but a person can be involved as much as they want to be in any church. They can 
be in as many activities as they really want to have going in that church.

KERRY: Even in a small church, if folk put enough in then you can get enough going for yourself. It seems to be so in otsego with Dolly Salisbury keeping things moving.

CAROL: I know it. I'm really excited about that. I was worried about her for a while but she's really...

KERRY: Dolly sort of really gets things going.

CAROL: She's in the same position I was in, because she's the oldest kid.

KERRY: Right, so she's got.to....

CAROL: And so she feels the responsibility now for all those younger kids and it's good to see that because that's what's going to keep her there, having responsibility and someone that needs her.

KERRY: I think they appreciate what she does there too, and they usually try and support her. Being a small church they do support one another and the adults support her too. When she comes up with a scheme she gets pretty good support from the older folk which is the way it seems to operate in a smaller church where folk make a choice to do something, then everyone generally supports it, even if they are ninety or nine years old. Even if it's a teenager that makes the decision they all seem to do it together.

What about you Dale. What about coming over here and telling us a bit about your past history. Have you usually gone to a big church or a small church? What's 
been your pattern? Now you come from down south somewhere do you?

DALE: No, east.

KERRY: East. Where were you brought up? What size church?

DALE: It was a small church but it was a little bit larger than the ones we've just been talking about.

KERRY: What was it, below one hundred?

DALE: $\quad$ Yes, it was between fifty and seventh-five.

KERRY: Okay, so you classify it as a small church?

DALE: Right.

KERRY: Now how did you feel about that when you were growing up?

DALE: Oh, it was great because I knew everybody there and it was sort of like a family because we all worked together.

KERRY: So if you were taken out and put into a church of 500 or Pioneer or something, how would you feel? I suppose you've been to these churches, you've visited them? What are your feel ings?

DALE: It feels like if I wasn't there nobody knew about it except for my very closest friends.

KERRY: Do you think that that's important to you when you go to church that you need to know the folk there, that if there's not this atmosphere it's not the same, it's not church? or is it still church?

DALE: It's still church but it's not like a feeling of belonging there--of a family unity there.

KERRY: Because some big churches have people at the door who greet you, and they're usually friendly. You don't think 
this is enough?

CAROL: That's their job. They're supposed to be there doing that. It's different than someone just coming up and saying, "Hey, I'm really glad you're here today." You know, "It's nice to see you. How's your week been going?" It's totally different than that. It's just someone that's there because they're supposed to be there, no matter how friendly they are.

KERRY: And you don't get many people that come up to you and say that spontaneously?

CAROL: I've never had that happen in Pioneer. And it didn't happen very often at Kalamazoo either.

KERRY: Well that's been a big help and we've come up with some. ideas that are a little new, and are fruitful. Dale, I've seen you up there in Otsego a few times. How did you feel that you fitted in--even without Carol's influence?

DALE: Well, I fit in pretty well.

KERRY: When you were a stranger coming in there do you think that they accepted you or they gave you a little while on probation before they opened up their arms to you, or were they pretty spontaneous?

DALE: No they were pretty spontaneous. They welcomed me right from the very first time I was there.

KERRY: Do you think because you were friendly with Carol and they thought they could trust her--so they could trust you too? DALE: I'm not sure. May have been, I can't remember. They were friendly to me even though, you know .... 
KERRY: Even though you had just started going there?

DALE: Right.

KERRY: Have you found this generally with most small churches that you've gone to?

DALE: Most of the ones that I've gone to, yes.

KERRY: I suppose they're not all like that, but it's good to hear that perhaps you've been to many that have been. Did you find that down here at Chickaming?

DALE: Oh yes. As soon as we walked in they were asking where we were from, what we were doing, where we 1 ived.

KERRY: Interested to have you there.

DALE: Yes. They were interested in where we have been, what we were doing, and ourselves, especially.

KERRY: Do you think that that's important for people, even young people like yourself, to feel in a family atmosphere?

DALE: Yes, you get to know each other's interest, and each other's talents, and their desires. Maybe it's more important to younger people than older people, you know why when you think about it.

KERRY: Anyway, thank you for your help and I think that you've given us some ideas. Do you think you will be small church people until the Lord comes? That will be where your heart is, do you think?

DALE: $\quad$ That's probably where most of my heart will be. I'11 go wherever He wants me to go.

KERRY: And what about you Carol? Are you the same too?

CAROL: I'm the same. 
KERRY: You like that small environment where you know folk?

CAROL: Definitely.

KERRY: I can appreciate that too. Thank you both for your help.

It is Sabbath, June 21, and we're at Otsego. Lloyd Hamilton is with me, but unfortunately his wife, Laura, can't be here. Lloyd had been going to the Otsego church for some considerable time but now he is attending the Battle creek church.

KERRY: How long had you actually been going to Otsego, Lloyd?

LLOYD: Oh, I think about five years. Raised in a little church too.

KERRY: Where was that, Lloyd?

LLOYD: That was up in northern Minnesota.

KERRY: What size church would that have been?

LLOYD: Probably thirty, thirty-five members. Just a little bit smaller than here.

KERRY: Well often we're about that number here, aren't we?

LLOYD: Yes.

KERRY: Now you transferred closer to your job with the Sanitarium in Battle Creek? Is that right?

LLOYD: Yes. I started with them just over seven years ago.

KERRY: Lloyd, as I understand, you moved here to take up your job with the Battle Creek Sanitarium about seven years ago, and about the same time I think you said you started to attend here at 0tsego? What made you attend this little church because there is plenty of other churches around and the Tabernacle too? 
LLOYD: Well before we started working at the San, or before I started working there, we lived in Michigan about a year. We went to Kalamazoo first. We thought about going here when we first came back to Michigan, but then we didn't for different reasons. And then when the church closed down and they reopened it we thought we would come here to help get things going again in whatever way we could.

KERRY: So that was in '73?

LLOYD: '74. I think we started sometime in '74. It was 173 or 174.

KERRY: It was when the church started up again wasn't it?

LLOYD: Right. So then we went here, and we were members until about a year ago.

KERRY: What was it about Otsego that made you like coming here? There are other churches around--Kalamazoo is a bigger church. Was there anything about the fact that you changed over here other than just to see it get going, or was there some things about the church?

LLOYD: Well it was a good bit closer for us.

KERRY: Were you living in Battle creek at that time?

LLOYD: No. We were living outside of Plainwell for the first two years that we were at the church here in Otsego. I drove back and forth into work, and then we moved over to Battle Creek and we kept on driving back over here to go to Sabbath School and Church.

KERRY: What was it about the church? Was it just that you were close by here and that it was nearby, that made you come 
here or was there anything else about the church?

LLOYD: Well we liked the little church better and the year we went to Kalamazoo we never realiy felt that much at home there.

KERRY: You went to Kalamazoo first, for about a year?

LLOYD: Yes. And in the little churches it's easier to get acquainted with all the members, you seem more like one of the family, whereas in the big church you know some but there are a lot of them you really don't know.

KERRY: And you feel that that's an important thing, to know the other people in the church?

LLOYD: Well, I think we're going to live as a family in heaven.

KERRY: So you think you ought to know the family down here?

LLOYD: YeS.

KERRY: Do you think in the small church jobs are shared with more of the people?

LLOYD: Oh yes.

KERRY: Do you think you get used more? I know you used to teach Sabbath School.

LLOYD: Right. They do not have as many people to be picking from in order to fill all the jobs. It makes me think of another little church that I have not mentioned to you about. We went to church in Griffin, Georgia, for a year and a half; when we first went there, there was one adult man attending the church, and they had about thirty-five members. He was the head deacon, the only head deacon, he was the head elder, the only head elder, because there 
was no-one else.

KERRY: There was hardly anyone there to use.

LLOYD: Right.

KERRY: So you like the family atmosphere here, you like to know everyone--you found it friendly here?

LLOYD: Yes.

KERRY: So that's some positive things about the church. About twelve months ago you moved your membership to Battle Creek, which is just around the corner from where you live now. What are some things you're finding there that were inadequate here?

LLOYD: We11, of course one big reason why we transferred membership was because we have been living in Battle creek for the last three or four years and with the price of gas up so high. But probably much more than that is another reason. Our experience is that it has been harder to keep the boys interested in the church, in a little church I do feel. Maybe this is a problem of the little church, and there's not as much that you can do about it as you would like to, but the Sabbath School programs seem to be a problem. I don't think that most of the young people get a lot out of the church service, not because they couldn't, most of them don't try to get a whole lot out of it. Whereas the Sabbath School, or the youth department, and so on, hopefully will be geared more for them and they will get more. I realize that the small membership is hard, but I felt that in the Sabbath School situation, they were really getting 
nothing out of it and they did not like coming. I don't think the reason for not liking coming was because they weren't getting enough out of Sabbath School, but they felt they had more of their friends over there in Battle creek. But I'll be honest with you. The first time we came back to visit after we transferred our membership, I remember in particular, I was talking with the boys about what they did at Sabbath School and they said that all they did that Sabbath for the whole hour was just discuss some up-coming social programs. To me, I do not think that that's what the Sabbath School is all about. I know it's hard on the small church, but I think our young people need the guidance. And really I'm a little bit disappointed. So often we would choose our youth leaders from new members in the church that really, I think, needed the instruction and counsel to be found in the adult Sabbath School class, much more than they needed to be leading young people to Christ--when they had not really been lead there yet themselves.

KERRY: So there needs to be a tightening up of the children's departments, and that can be so easily neglected in a small church.

LLOYD: Right. There's just not enough of the personnel. I think just like everything else you've got to realize, I mean the church as a whole will have to realize that there's a need before they will do much about it. Even in our own individual lives if we don't see a need in our lives by correcting the situation, we're not going to do too much about it. 
I've talked with different ones occasionally down through the years but I never say that they really felt there was that much of a need there. Consequently, if people don't see a need they're not going to work at it.

KERRY: I think you've brought out a good point there--that maybe the best talent in the church should be put into those areas which are teaching the children--for the small church can often find this a weakness and they need to make sure it gets stronger. Are you finding that those needs are getting met better now in their Sabbath School classes?

LLOYD: We11, I'll tell you. They have goals and they are encouraged to study more. However, I will admit that children, like the old saying, can be lead to water but you can't make them drink. There are some infiuences in the big church there which is not all good and these could lead them away from Christ.

KERRY: Thank you for your help Lloyd, and thank you for coming over to Otsego today--it is good to still see you attend over here now and then. 


\section{BIBLIOGRAPHY}




\section{BIBLIOGRAPHY}

\section{Books}

Anderson, Philip, and Anderson, Phoebe. The House Church. Nashville, Tenn.: Abingdon Press, 1975.

Anderson, Ray S., ed. Theological Foundations for Ministry. Grand Rapids, Mich.: Wm. B. Eerdmans, 1979.

Andriessen, Paulus. The Birth of the Church. Staten Island, N.Y.: Alba House, n.d.

Barth, Karl. The Christian Life. London: Student Christian Movement Press, 1930 .

- Church Dogmatics: The Doctrine of Reconciliation.

4 vols. Edinburgh: T. \& T. Clark, 1969.

- Community, State and Church. New York: Doubleday and Co., 1960 .

Bavinck, Johannes $H$. The Impact of Christianity on the NonChristian World. Grand Rapids, Mich.: Wm. B. Eerdmans, 1948.

Belew, M. Wende11. Churches and How They Grow. Nashville, Tenn.: Broadman Press, 1971.

Berkouwer, G. C. The Church: Studies in Dogmatics. Grand Rapids, Mich.: Wm. B. Eerdmans, 1976.

Bonhceffer, Dietrich. The Communion of Saints. New York:

Harper and Row Publishing Company, 1963.

- Life Together. New York: Harper and Brothers Pubi ishing Company, 1954.

Brewer, Earl D. C. A Chartbook of Urban Parish and Rural Parish. Atlanta; Religious Research Center, Candler School of Theology, Emony University, 1966.

Brinton, Crane. European Intellectual History. New York: Macmillan, 1964. - Ideas and Men. New York: Prentice-Hall, 1950. 
Brunner, Emil. The Misunderstanding of the Church. Philadelphia: Westminster Press, 1953.

Carroll, Jackson W., ed. Small Churches Are Beautiful. New York: Harper and Row, 1977.

Chaney, Charles L., and Lewis, Ron S. Design for Church Growth. Nashville, Tenn.: Broadman Press, 1977.

Clark, Robert E. D. Science and Christianity--A Partnership. Mountain View, Cal.: Pacific Press, 1972.

Cole, Alan. The Body of Christ: A New Testament Image of the Church. Philadelphia: Hestminster Press, 1964.

Come, Arnold B. Agents of Reconciliation. Philadelphia: Westminster Press, 1964.

De Ridder, Richard. Discipling the Nations. Grand Rapids, Mich.: Baker Book House, 1975. - The Dispersion of the People of God. Kampen, Netherlands: J. H. Kok, 1977.

Douglas, J. D., ed. Let the Earth Hear His Voice. Minneapolis, Minn.: World Wide Publishers, 1975.

Driver, John. Community and Commitment. Scottdale, Penn.: Herald Press, 1976.

Dudley, Carl S. Making the Small Church Effective. Nashville, Tenn.: Abingdon, 1978.

Gay, Peter. "The Enlightenment in Its World." In Issues in Western Civilization. 2 vols. Edited by Leon Apt. 2:2-22. Boston: Holbrook Press, 1974.

Green, Hollis L. Why Churches Die. Minneapolis, Minn.: Bethany Fellowship, 1972.

Halverson, Richard C. How I Changed My Thinking about the Church. Grand Rapids, Mich.: Zondervan Publishing House, 1972.

Hanson, Richard. Christian Priesthood Examined. London: Lutterworth Press, 1979.

Hesselgrave, David J., ed. Theology and Mission. Grand Rapids, Mich.: Baker Book House 1978.

Hinson, Gienn E. The Integrity of the Church. Nashville, Tenn.: Broadman Press, 1978. 
Hoge, Dean R., and Roozen, David A., eds. Understanding Church Growth and Decline. New York: Pilgrim Press, 1979.

Judge, E. A. The Social Pattern of the Christian Groups in the First Century. London: Tyndale Press, 1960.

Judy, Marvin R., ed. The Church in Town and Country Areas. Dallas, Tex.: Southern Methodist University, 1961.

Kilian, Sabbas J. Theological Models for the Parish. New York: Alba House, 7977

Knox, John. The Church and the Reality of Christ. London: Collins, 1963.

Kung, Hans. The Church. New York: Sheed and Ward, 1967.

Lindgreen, Alvin J., and Shawchuck, Norman. Management for Your Church. Nashville, Tenn.: Abingdon, 1977.

Lindsay, Thomas M. The Church and the Ministry in the Early Centuries. New York: George H. Doran Co., 1902.

Loughborough, J. N. The Church and Its Organization. Mountain View, Cal.: Pacific Press, 1906.

McGavran, Donald A., and Arn, Winfield C. Ten Steps for Church Growth. San Francisco: Harper and Row, 1977.

Macmurray, John. Persons in Relation. New York: Harper and Brothers, 1961 . - The Self as Agent. London: Faber and Faber, 1957.

MacNair, Donald J. The Growing Local Church. Grand Rapids, Mich.: Baker Book House, 1975.

Madsen, Paul 0. The Small Church--Valid, Vital, Victorious. Valley Forge, Penns.: Judson Press, 1975.

Mavis, W. Curry. Advancing the Smaller Local Church. Winona Lake, Ind. : Light and Life Press, 1957.

Mayer, Herbert T. Pastoral Care: Its Roots and Renewal. Atlanta, Ga: John Knox Press, 1979.

Meeks, M. Douglas. Origins of the Theology of Hope. Philadelphia: Fortress Press, 1974.

Mertz, Donald L. New Congregations. Philadelphia: Westminster Press, 1967. 
Meyners, Robert, and Wooster, Claire. Solomon's Sword: Clarifying Values in the Church. Nashville, Tenn.: Abingdon Press, 1977.

Minear, Paul S. Images of the Church in the New Testament. Philadelphia: Westminster Press, 1960.

Moltmann, Jurgen. The Church in the Power of the Spirit. New York: Harper and Row, 1977.

- Hope for the Church. Nashville, Tenn.: Abingdon Press, 1979.

- The Open Church. London: S.C.M. Press, 1978.

Mylander, Charles. Secrets for Growing Churches. New York: Harper and Row Publishers, 1979.

Neill, Stephen. The Unfinished Task. London: Lutterworth Press, 1957.

Newbigin, Lesslie. The Open Secret. Grand Rapids, Mich.: Wm. B. Eerdmans, 1978.

Nygren, Anders. Christ and His Church. London: S.P.C.K., 1957.

Oosterwa 1, Gottfried. Patterns of S. D.A. Church Growth in America. Berrien Springs, Mich.: Andrews University Press, 1976.

Pennington, Chester A. Half-Truths or Whole Gospel? Nashville, Tenn.: Abingdon, 1972.

Pittenger, Norman. The Christian Church as Social Process. London: Epworth Press, 1971.

Rahner, Karl. The Shape of the Church to Come. London: S.P.C.K., 1974.

Rauff, Edward A. Why People Join the Church. New York: Pilgrim Press, 1979.

Richardson, James T.; Stewart, Mary V.; Simmonds, R. B. Organized Miracles. New Brunswick, N.J.: Transaction Books, 1979.

Robinson, John A. T. On Being the Church in the World. Philadelphia: Westminster Press, 1960.

Schaller, Lyle E. Assimilating New Members. Nashville, Tenn.: Abingdon, 1978. - Hey, That's Our Church. Nashville, Tenn.: Abingdon, 1975. 
- The Local Church Looks to the Future. Nashville, Tenn.: Abingdon, 1968.

- Parish Planning. Nashville, Tenn.: Abingdon, 1971.

- Survival Tactics in the Parish. Nashville, Tenn.: Abingdon, 1977.

Schnackenburg, Rudolf. The Church in the New Testament. London: Burns and Oates, 1974.

Schumacher, E. F. Small Is Beautiful: Economics as if People Mattered. New York: Harper and Row, 1973.

Seventh-day Adventist Church Manual. Washington, D.C.: General Conference of Seventh-day Adventists, 1976.

Thielicke, Helmut. I Believe. Philadelphia: Fortress Press, 1968.

Thiessen, John C. Pastoring the Smaller Church. Grand Rapids, Mich.: Zondervan Publishing House, 1962.

Thornton, L. S. Christ and the Church. Westminster: Dacre Press, $19 \overline{56 .}$

Trexler, Edgar R., ed. Creative Congregations. Nashville, Tenn.: Abingdon, 1972.

Wagner, C. Peter. Your Church Can Grow. Glendale: Rega 1, 1976. - Your Spiritual Gifts Can Help Your Church Grow. Glendale: Regal, 1979.

Warner, W. Lloyd. The Family of God. New Haven: Yale University Press, 1961.

Webber, George W. The Congregation in Mission. Nashville, Tenn.: Abingdon, 1964.

Werning, Waldo J. Vision and Strategy for Church Growth. Chicago: Moody Press, 1977.

White, Ellen G. Testimonies for the Church. 9 vols. Mountain View, Cal.: Pacific Press, 1948.

Willimon, William H., and Wilson, Robert L. Preaching and Worship in the Small Church. Intro. by Lyle E. Schaller. Nashville, Tenn.: Abingdon, 1980.

Wilson, Bryan R. Sects and Society. Berkeley: University of California Press, 1961. 
Worley, Robert C. A Gathering of Strangers. Philadelphia: Westminster Press, 1976.

Journal Articles and Periodicals

Arnott, Robert L. "Systems Theory and Pastoral Adminstration." Christian Ministry 3 (September 1972): 14-20.

Barr, Browne. "Smaller and Smaller, Better and Better." Christian Century 95 (September 13, 1978): 828.

Blizzard, Samuel W. "The Minister's Dilemma." Christian Century 73 (April 1956): 508-510.

Copeland, E. Luther. "Church Growth in Acts." Missio 4 (January 1976): 13-26.

Dudley, Carl S. "Membership Growth: The Impossible Necessity." Christian Ministry 8 (July 1977): 8-12.

Erickson, Theodore H. "From Process to Covenant." Christian Ministry 8 (July 1977): 12-15.

Filson, Floyd V. "The Significance of the Early House Churches." Journal of Biblical Literature 58 (1939): 105-112.

Frank1, V. E. "Beyond Self-Actualization and Self-Expression." Journal of Existential Psychiatry 1. (1960): 5-20.

Hanson, Geddes $H$. "Overdosing in Organizational Development: Towards Criticalness in Pastoral Administration." Pastoral Psychology 24 (Spring 1976): 206-214.

Inskeep, Keith L. "Finding One's Own Success Model." Christian Ministry 8 (Ju7y 1977): 20-24.

Monkres, Peter. "Small Is Beautiful: Churches as if People Mattered." (Editorial) Christian Century 95 (May 10, 1978): 492-493.

Newbigin, Lesslie. "What Is a Local Church Truly United?" Ecumenical Review 29 (Apri1 1977): 115-128.

Rohr, R. "Building Family: God's Strategy for the Reluctant Church." Sojourner 8 (January 1979): 20-22.

Schaller, Lyle E. "Looking at the Small Church." Christian Ministry 8 (July 1977): 5-9.

. "Self-Evaluation Questions for the Small Church." Christian Ministry 8 (July 1977): 16-19. 
Wicker, Allan W. "Assimilation of New Members in a Large and a Small Church." Journal of Applied Psychology 55: 157-156.

. "Size of Church Membership and Member's Support of Church Behavior Settings." Journal of Personality and Social Psychology 13: 278-288.

"Organization Size..." Behavioral Science 17 (1972): 499-513.

"Effects of Merger . . . ." Journal of Applied Psychology 59: 24-30.

Wilkien, Paul. "Size of Organizations and Member Participation in Church Congregations." Administrative Science Quarterly 16 (June 1971): $173-179$.

\section{Theses}

Babbitt, James J. "An Examination of Church Renewal among the Clustered Congregations in Portland, Oregan." Ph.D. dissertation, Garrett Biblical Institute, 1971.

Bietz, G. C. "The Concept of Christian Witness." D.Min. project thesis, Andrews University Theological Seminary, 1976.

Bradsby, Robert Wayne. "An Investigation of Theories of Motivation and Incentives as they Relate to Lay Leadership in the Local Church." D.R.E. thesis, South Western Baptist Theological Seminary, 1958.

Christiansen, Charles F. "Training Lay Persons to Engage in the Ministry of Caring." D.Min. dissertation, Drew University, 1979.

Clingenpel1, Michael J. "Southern Baptist Churches which Disband: Implications for Theology and Terminal Ministry." Ph.D. dissertation, The Southern Baptist Theological Seminary, 1979.

Conyers, Abda J., III. "Jurgen Moltmann's Concept of History." Ph.D. dissertation, The Southern Baptist Theological Seminary, 1979.

Giller, Eoin B. "Building up the Body of Christ--A Study in Church Revitalization Leading to Church Growth." D.Min. project thesis, Andrews University Theological Seminary, 1977. 
Johnston, 01iver L. "The Introduction of Management by Objectives into the Buchanan, Michigan, Seventh-day Adventist Church." D.Min. project thesis, Andrews University Theological Seminary, 1979.

Marsh, Gerald Eugene. "The Biblical and Theological Bases for the Layman's Role in the Ministry of the Church." Th.D. dissertation, South Western Baptist Theological Seminary, 1964.

Nemeth, Alex N. "The Training of Leaders as Coordinators for the Experience of Koinonia in a Small Group Setting." D.Min. dissertation, Drew University, 1979.

Rhoads, Robert I., Sr. "Church Growth and Decline: A Case Study of the Variable Factors Effecting Membership Ingression and Egression of Four Churches." D.Min. dissertation, Lancaster, Lancaster Theological Seminary, 1979.

Rodgers, John E. "Assessing the Socio-Psychological Interior of the Family: An Empirical Basis for the Study of Family Functions." Ed.D. dissertation, Berrien Springs, Michigan Andrews University, 1979.

Smart, Reginald K. "The Local Protestant Church as an Instrument of Mission: An Analysis of Reasons and Remedies for its 'Ineffectiveness." Th.D. dissertation, Boston University School of Theology, 1964.

Welliver, Kenneth B. "Pentacost and the Early Church: Patristic Interpretation of Acts 2." Ph.D. dissertation, Yale University, 1961.

Yorton, Bernett L. "The Recovery of the Potential of the Layman in the Church." P.T.D. dissertation, Pasadena, Fuller Theological Seminary, 1970.

Young, James M. "Five Center City Churches Surviving for Service." D.Min. dissertation, Lancaster Theological Seminary, 1979.

\section{Miscellaneous}

Faith Action Advance Manual. Washington, D.C.: General Conference of Seventh-day Adventists, 1979.

Modified Hout's Questionnaire. Pasadena: Cal.: Fuller Evangelistic Association, 1978. 